\title{
RULISON SITE CORRECTIVE ACTION REPORT
}

DOE Nevada Operations Office

Las Vegas, Nevada

September 1996

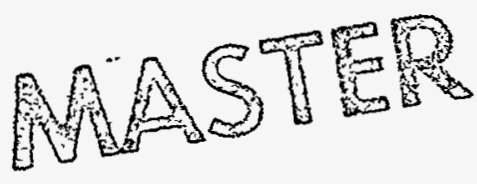




\section{DISCLATMER}

Portions of this document may be illegible in electronic image products. Images are produced from the best available original document. 
RULIŚON SITE

CORRECTIVE ACTION REPORT

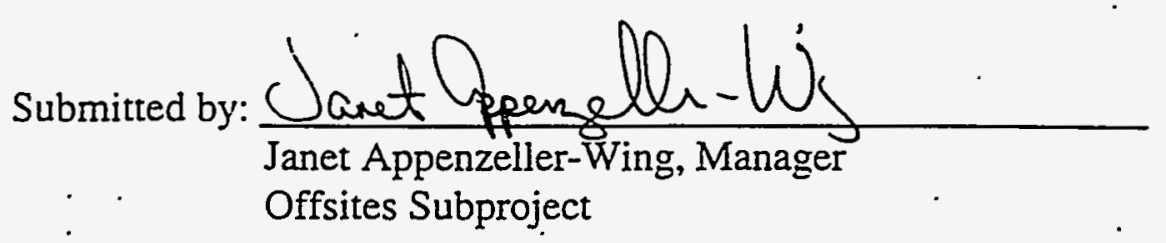

Date: $9 / 26 / 96$ Offsides Subproject

Approved by: Maund \&. \& Refer

Date: $9 / 26 / 96$ Environmental Restoration Division 


\section{Table of Contents}

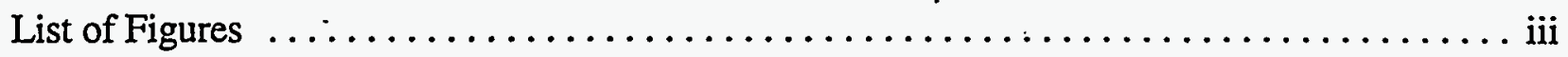

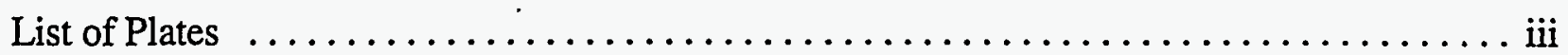

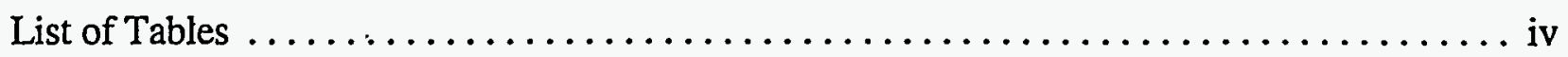

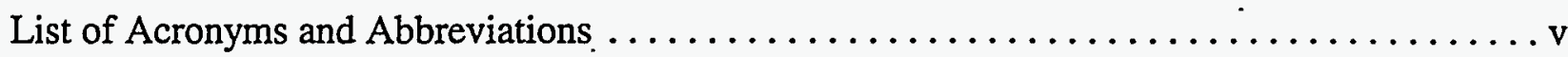

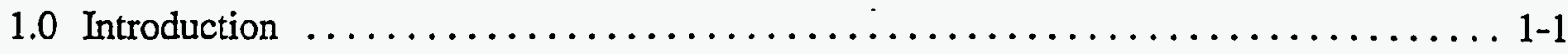

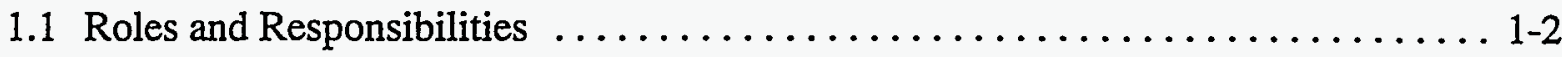

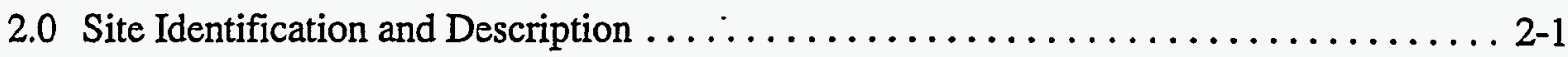

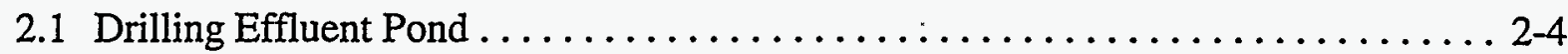

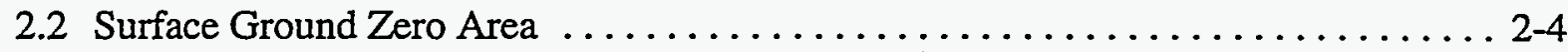

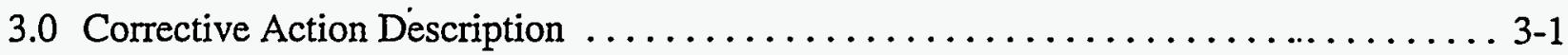

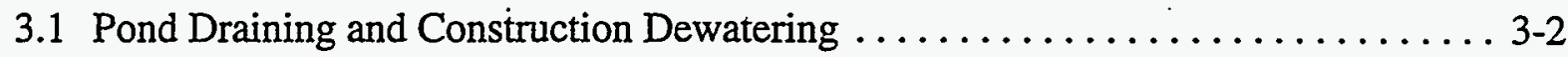

3.1.1 Pond Draining and Construction Dewatering Analytical Results ....... 3-4

3.2 Pond Sediment Stabilization and Removal ..................... 3-6

3.2.1 Cleanup Verification Analytical Results . ................. 3-7

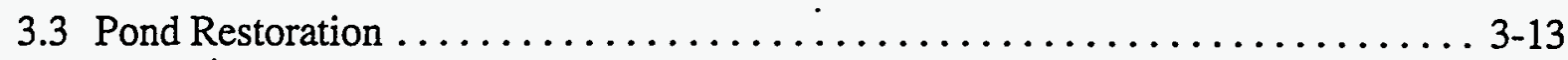

4.0 Surface Ground Zero Area Investigation $\ldots \ldots \ldots \ldots \ldots \ldots \ldots \ldots \ldots \ldots \ldots \ldots \ldots \ldots .1$

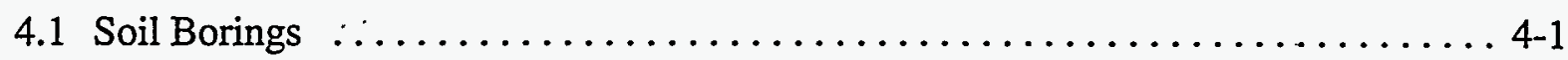

4.1.1 Soil Boring Drilling and Sampling $\ldots \ldots \ldots \ldots \ldots \ldots \ldots \ldots \ldots, 4-1$

4.1.2 Soil Boring Abandonment $\ldots \ldots \ldots \ldots \ldots \ldots \ldots \ldots \ldots \ldots \ldots \ldots, 4-3$

4.1.3 Soil Boring Analytical Results $\ldots \ldots \ldots \ldots \ldots \ldots \ldots \ldots \ldots \ldots \ldots .4,4$

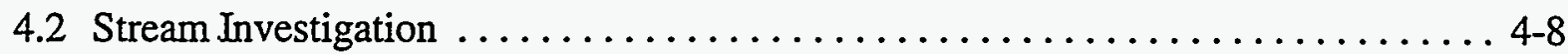

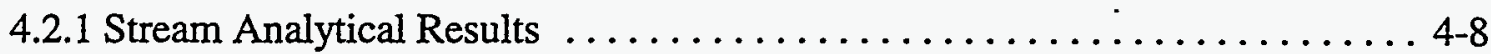

4.3 Radiological Investigation $\ldots \ldots \ldots \ldots \ldots \ldots \ldots \ldots \ldots \ldots \ldots \ldots .4 .9 \ldots \ldots$

4.3.1 Radiological Analytical Results . .................... 4-11

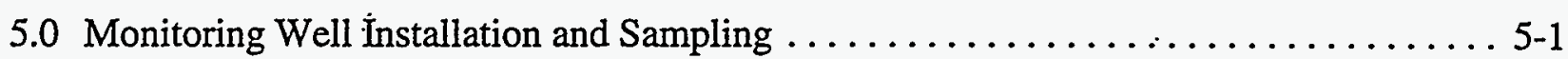




\section{Table of Contents (Continued)}

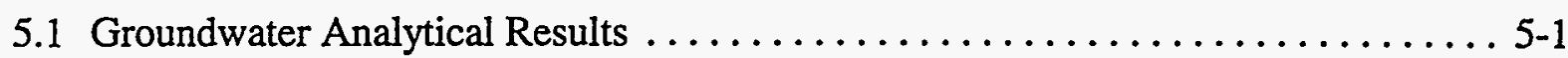

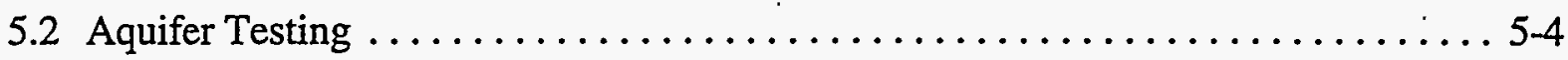

6.0 Summary and Conclusions $\ldots \ldots \ldots \ldots \ldots \ldots \ldots \ldots \ldots \ldots \ldots \ldots \ldots, 6,1$

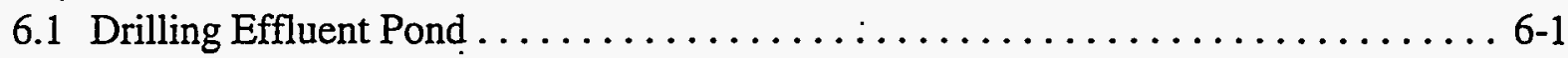

6.2 Surface Ground Zero Area $\ldots \ldots \ldots \ldots \ldots \ldots \ldots \ldots \ldots \ldots \ldots \ldots, 6,1$

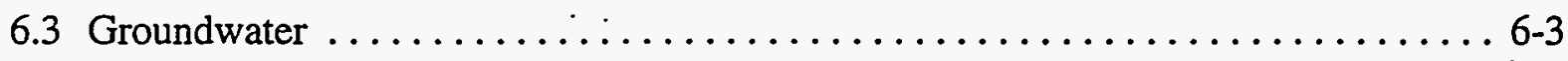

7.0 Drilling Effluent Pond Closure Certification $\ldots \ldots \ldots \ldots \ldots \ldots \ldots \ldots \ldots \ldots \ldots \ldots \ldots \ldots \ldots$

7.1 U.S. Department of Energy . . . . . . . . . . . . . . . . . . . . 7-1

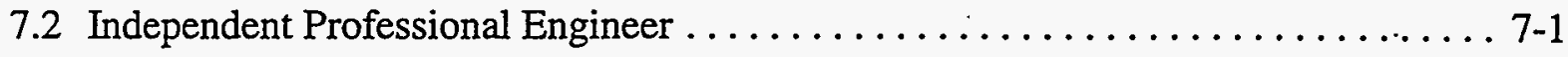

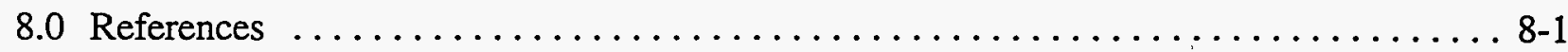

Appendix A - Variances from the Approved Work Plans $\ldots \ldots \ldots \ldots \ldots \ldots \ldots \ldots$ A-1

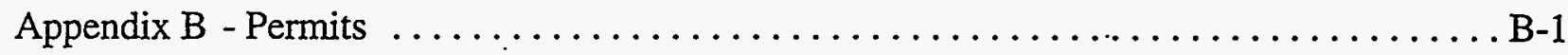

Appendix C - Pond Draining and Construction Dewatering Analytical Results . ........ C-1

Appendix D - Stabilized Sediment Analytical Results ................... D-1

Appendix E - Pond Cleanup Verification Analytical Results ................. E-1

Appendix F - Surface Ground Zero Area Soil Boring Logs . ................ F-1

Appendix G - Monitoring Well Boring Logs and Construction Diagrams ............ G-1

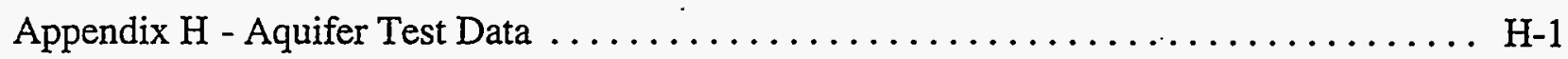

Appendix I - Risk Assessment . . . . . . . . . . . . . . . . . . . 


\section{List of Figures}

Number

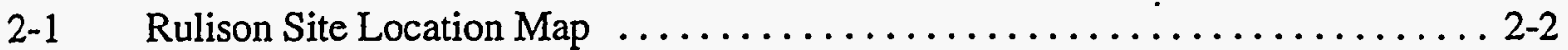

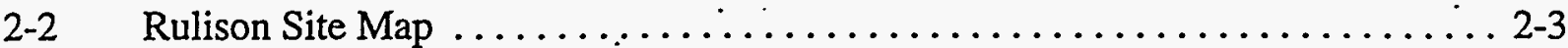

3-1 Rulison General Site Layout Diagram, Pond Water Discharge System . . . . . 3-3

3-2 Rulison Drilling Effluent Pond Verification Soil Sampling Locations ........ 3-8

3-3 Verification Soil Sampling Locations and Total Petroleum

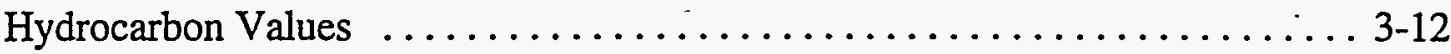

4-1 Surface Ground Zero Area Soil Boring and Stream Sample Locations . . . . . . 4-2

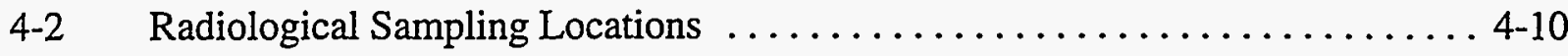

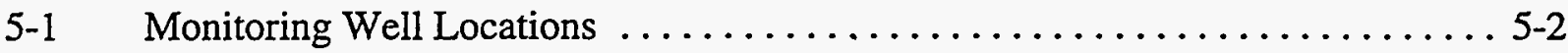

6-1 Areas of Sediment With TPH Concentrations Between $250 \mathrm{mg} / \mathrm{kg}$ and $1,000 \mathrm{mg} / \mathrm{kg} \ldots \ldots \ldots \ldots \ldots \ldots \ldots \ldots \ldots \ldots \ldots \ldots \ldots \ldots \ldots .6 .2$

\section{List of Plates}

Plate - Rulison Project 


\section{List of Tables}

Number

Title

Page

3-1 Pond Draining and Construction Dewatering Analytical Results $3-5$

3-2 Pond Cleanup Verification Analytical Results Total Petroleum Hydrocarbons, Toxicity Characteristic Leaching Procedure Chromium . . : .......... 3-10

4-1 Surface Ground Zero Area Soil Boring Sample Analytical Results 4-5

4-2 Surface Ground Zero Area Stream Sample Analytical Results 4-9

4-3 Surface Ground Zero Area Radiological Sample Analytical Results $4-12$

5-1 Groundwater Analytical Results, October 1995 Samples $5-3$ 


\section{List of Acronyms and Abbreviations}

AEC U.S. Atomic Energy Commission

AQTESOLV Aquifer Test Solver software program

BGS Below ground surface

BTEX Benzene, toluene, ethylbenzene, and xylene

CAP Corrective Action Plan

CDPHE Colorado Department of Public Health and Environment

$\mathrm{cm} / \mathrm{sec} \cdot$ Centimeter(s) per second

Cr Chromium

DOE U.S. Department of Energy

ERDA U.S. Energy Research and Development Administration

$\mathrm{ft} \quad$ Foot (feet)

gpm Gallon(s) per minute

HDPE High-density polyethylene

in. Inch(es)

IT IT Corporation

$\mathrm{km} \quad$ Kilometer(s)

LTGMP Long-Term Groundwater Monitoring Plan

m Meter(s)

$\mathrm{m}^{3} \quad$ Cubic meter(s)

MCC Maximum concentration of contaminants

MCL . Maximum contaminant level

$\mathrm{mg} / \mathrm{kg} \quad$ Milligram(s) per kilogram

$\mathrm{mg} / \mathrm{L} \quad$ Milligram(s) per liter

mi Mile(s)

MS/MSD Matrix spike/matrix spike duplicate

OTP Organic Toxic Pollutants

$\mathrm{pCi} / \mathrm{g} \quad$ PicoCurie(s) per gram

$\mathrm{pCi} / \mathrm{L} \quad$ PicoCurie(s) per liter

PID Photoionization detector

PVC Polyvinyl chloride

QAPP Quality Assurance Project Plan

RCRA Resource Conservation and Recovery Act

SDWA Safe Drinking Water Act 
SGZ Surface ground zero

TCLP Toxicity Characteristic Leaching Procedure

TDS Total dissolved solids

TPH Total petroleum hydrocarbons

TSS . Total suspended solids

$\mu \mathrm{g} / \mathrm{kg} \quad$ Microgram(s) per kilogram

$\mu \mathrm{g} / \mathrm{L} \quad$ Microgram(s) per liter

VSAP Verification Sampling and Analysis Plan

$\mathrm{yd}^{3} \quad$ Cubic yard(s) 


\subsection{Introduction}

This Corrective Action Report describes the cleanup of petroleum hydrocarbon- and heavymetal-contaminated sediments from an old drilling effluent pond and characterization of the mud pits used during drilling of the R-EX well at the Rulison Site. The Rulison Site is located approximately 65 kilometers $(\mathrm{km})$ (40 miles [mi]) northeast of Grand Junction, Colorado. The . effluent pond was used for the storage of drilling mud during drilling of the emplacement hole for the 1969 gas stimulation test conducted by the U.S. Atomic Energy Commission (AEC). The cleanup activities described in this report were conducted between August and mid-November of 1995 and were undertaken voluntarily by the U.S. Department of Energy (DOE) to clean up the contaminated pond sediments to meet State of Colorado and Federal soil quality standards and guidelines.

The cleanup activities were governed by the approved draft Rulison Corrective Action Plan (CAP) (DOE, 1995a), the draft Rulison Verification Sampling and Analysis Plan (VSAP) (DOE, 1995b), the draft Rulison Long-Term Groundwater Monitoring Plan (LTGMP) (DOE, 1995c), and the Rulison Quality Assurance Project Plan (QAPP) (DOE, 1995d). The project work plans were reviewed by the Colorado Department of Public Health and Environment (CDPHE), and their comments and concerns about the plans were addressed satisfactorily. However, the CDPHE desired to have the landowner review the plans prior to issuing formal approval. Project schedules were timed to complete the work within the seasonal. window and for this reason work was commenced prior to receiving formal CDPHE approval of the plans. The plans were subsequently approved by the CDPHE without modification, and were issued as final documents in July 1996.

This report also describes the activities performed to determine whether contamination is present in mud pits used during the drilling of well R-EX, the gas production well drilled at the site to evaluate the effectiveness of the detonation in stimulating gas production. The investigation activities described in this report were conducted during the autumn of 1995 , concurrent with the cleanup of the drilling effluent pond. This report describes the activities performed during the soil investigation and provides the analytical results for the samples collected during that investigation. 


\subsection{Roles and Responsibilities}

The specific roles and responsibilities of DOE, IT Corporation (IT), and subcontractor personnel involved with the field work described in this report are described in the Rulison VSAP (DOE, 1995b). In addition to the personnel identified in the Rulison VSAP (DOE, 1995b), the IT Construction Manager was responsible for overseeing and directing the excavators and laborers performing the sediment excavation, stabilization, and removal work.

With the exception of the first week in October 1995, the DOE Site Manager was on site to provide approval of the work being conducted. In addition, the DOE Site Manager was responsible for providing technical input to the project, communicating with the CDPHE representative on issues and the status of the work being done, and interacting with the local public and press. The CDPHE representative visited the site periodically to observe the work. 


\subsection{Site Identification and Description}

The Rulison Site is located in the North $1 / 2$ of the Southwest $1 / 4$ of Section 25, Township 7 South, Range 95 West, Garfield County, Colorado, approximately 19 km (12 mi) southwest of Rifle, Colorado, and approximately $65 \mathrm{~km}$ (40 mi) northeast of Grand Junction, Colorado (Figure 2-1). The site is situated on the north slope of Battlement Mesa, on the upper reaches of Battlement Creek, at an elevation of approximately 2,500 meters $(\mathrm{m})(8,200 \mathrm{feet}[\mathrm{ft}])$. The valley in which the site is located is open to the north-northwest, and is bounded on the other three sides by steep mountain slopes that rise to elevations above $2,927 \mathrm{~m}(9,600 \mathrm{ft})$. A detailed description of the site's physical and environmental setting is presented in the Draft Corrective Action Plan, Rulison Drilling Effluent Pond (CAP) (DOE, 1995a).

Project Rulison was a joint AEC and Austral Oil Company (Austral) experiment, conducted under the AEC's Plowshare Program, to evaluate the feasibility of using a nuclear device to stimulate natural gas production in low-permeability gas-producing geologic formations. The experiment was conducted on September 10,1969, and consisted of detonating a 40-kiloton nuclear device at a depth of $2,568 \mathrm{~m}(8,426 \mathrm{ft})$ below ground surface (BGS). Natural gas production testing was conducted in 1970 and 1971.

The site was deactivated by the AEC and Austral in 1972. Cleanup associated with site deactivation consisted of removing all equipment and materials not needed for potential future gas production activities, and characterizing the site's radiological condition through extensive surface soil sampling. In 1977, the site was abandoned by the U.S. Energy Research and Development Administration (ERDA), the successor agency to the AEC and predecessor to DOE, and Austral, since neither ERDA nor Austral planned on commercially producing gas from the site. Cleanup associated with site abandonment consisted of removing all remaining equipment and materials, plugging the emplacement (R-E) and reentry (R-EX) wells (Figure 2-2), backfilling the mud pits adjacent to the R-EX well, removing the tritiumcontaminated soils, and further characterizing the radiological condition of the site through extensive surficial soil sampling. Detailed descriptions of the site deactivation and abandonment activities and radiological characterizations are presented in the Rulison Site Cleanup Report (AEC, 1973), the Project Rulison Well Plugging and Site Abandonment Final Report (ERDA, 1977), and the Rulison Radiation Contamination Clearance Report (Eberline, 1977). 


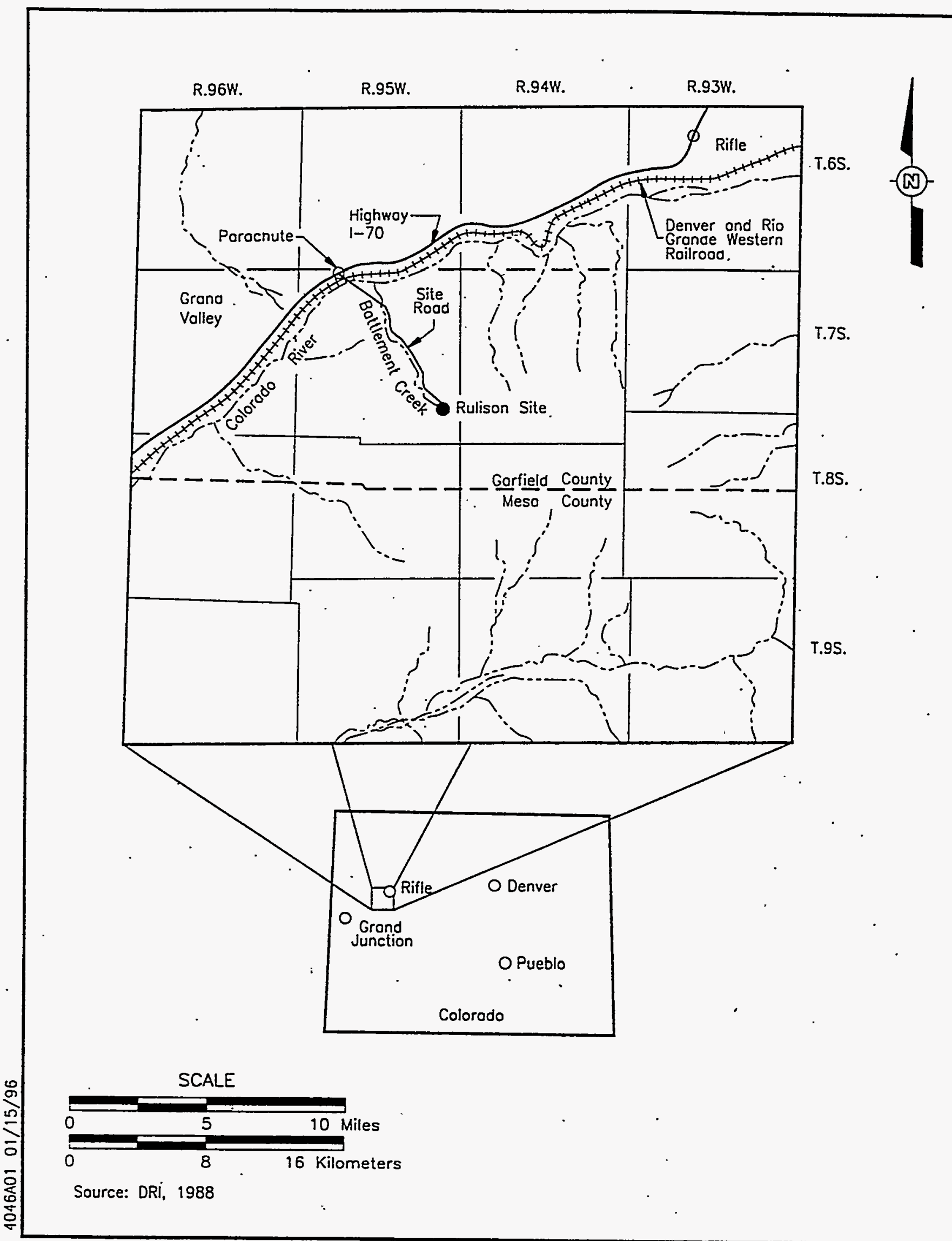

Figure 2-1

Rulison Site Location Map 


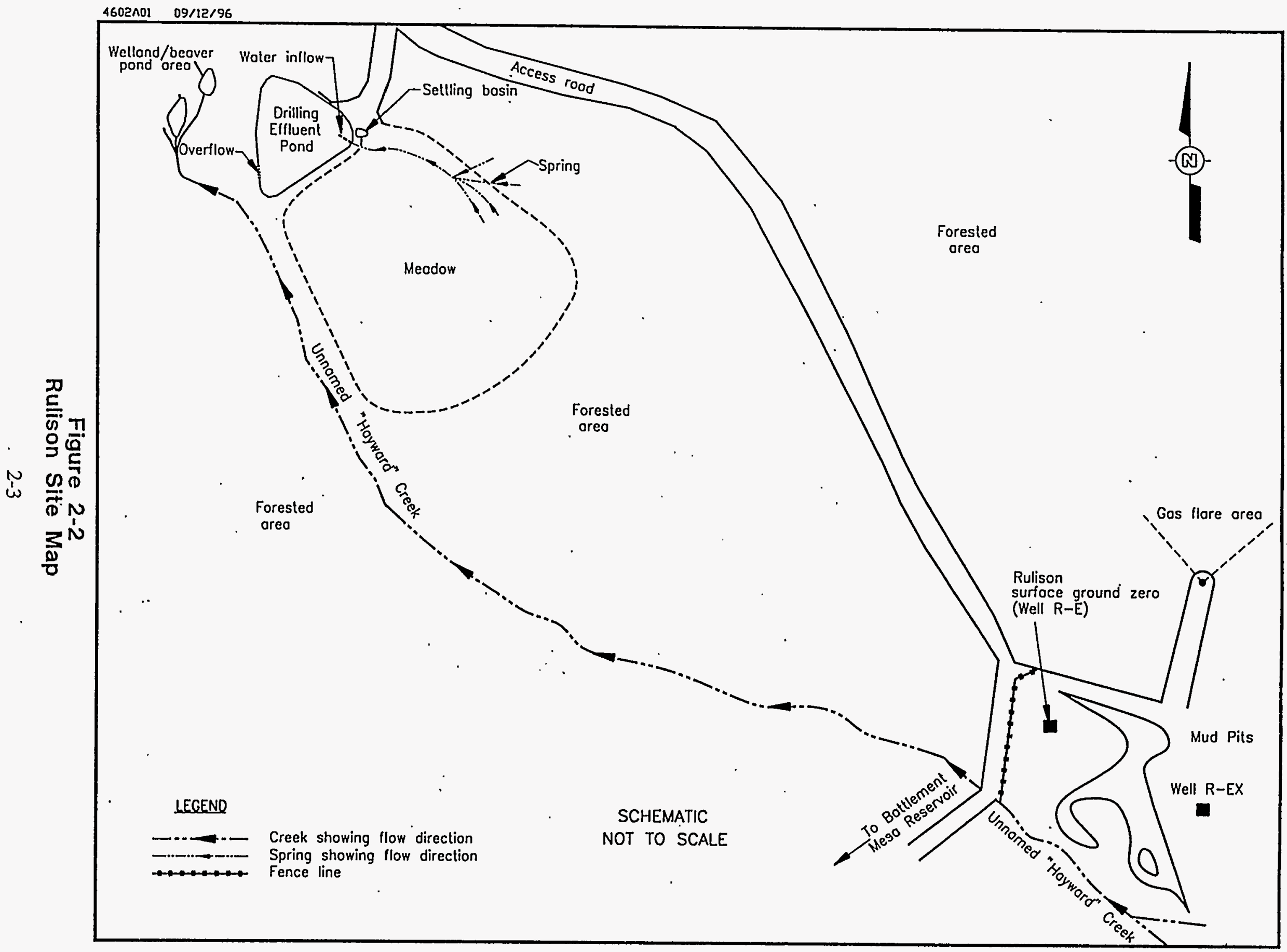




\subsection{Drilling Effluent Pond}

The drilling effluent pond is an engineered structure located approximately $400 \mathrm{~m}(1,312 \mathrm{ft})$ north-northwest of the surface ground zero (SGZ) emplacement well (Well R-E) (Figure 2-2). The pond covers approximately 0.5 hectare $(1.2 \mathrm{acres})$ as measured at the top of the berm, is

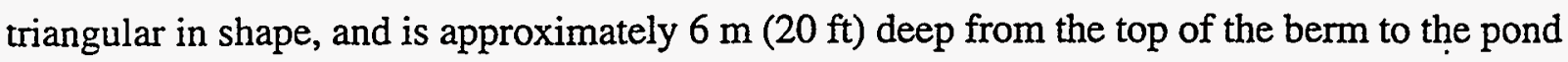
bottom.

The drilling effluent pond was used to store nonradioactive drilling fluids generated during drilling of the device emplacement well R-E. The drilling fluids consisted of bentonite drilling mud with additives such as diesel fuel and chrome lignosulfonate, used to improve drilling characteristics. Most of the drilling wastes were removed from the pond when the site was cleaned up and decommissioned in 1976; however, some drilling fluid was left in the pond. At the request of the property owner, the pond structure was left in place following completion of site decommissioning and was subsequently converted by the property owner to a freshwater holding pond containing aquatic vegetation, amphibians, and stocked rainbow trout.

In 1994 and 1995, four pond sediment sampling events were conducted to evaluate the extent of residual contamination from drilling wastes remaining in the pond. During the four sampling events, a total of 17 pond sediment samples, seven pond water samples, one stream sediment sample, one stream water sample, one spring water sample; five soil samples, and three fish tissue samples were collected. Concentrations of total petroleum hydrocarbons (TPH) and chromium were found in 11 pond sediment samples and the 5 soil samples taken from the old settling basin located adjacent to the pond. One pond sediment sample also contained elevated levels of lead, and elevated levels of barium were found in four of the soil samples collected from the settling basin and in one of the pond sediment samples. None of the analytes measured in the pond water, stream water, or spring water samples exceeded regulatory limits. A more detailed discussion of the 1994 and 1995 sampling events is presented in the Rulison CAP (DOE, 1995a).

Based on the results of the 1994 sampling events, the DOE decided to conduct a voluntary . cleanup action at the drilling effluent pond to reduce the levels of TPH and chromium in pond sediments and soils in and adjacent to the pond.

\subsection{Surface Ground Zero Area}

The soil samples collected from the SGZ area during the 1972 site deactivation and 1976 site abandonment activities were only analyzed for radiological constituents. Because historical 
records and data from the well R-E drilling effluent pond indicated that the fluids used for drilling well R-E contained non-radioactive contaminants (mainly TPH and chromium), which . were not previously analyzed for, the DOE decided to conduct a soil investigation in the vicinity of the R-EX well mud pits to evaluate the potential extent of non-radioactive contamination associated with storing the drilling fluids for that well. 


\subsection{Corrective Action Description}

The cleanup alternative selected for the Rulison Site drilling effluent pond was sediment stabilization and disposal at an approved landfill. The cleanup consisted of the following activities:

- Removing the fish from the pond and transplanting them to Hayward Creek or the beaver ponds

- Draining the pond

- Construction dewatering as necessary

- Excavating and stabilizing the contaminated pond sediments

- Transporting the stabilized sediments to an approved solid waste landfill for disposal

- Installing groundwater monitoring wells

- Restoring the pond and other areas which had been disturbed by the cleanup operation

The Rulison CAP (DOE, 1995a), VSAP (DOE, 1995b), LTGMP (DOE, 1995c), and QAPP (DOE, 1995d) (collectively referred to as the project Work Plans in this document) provide detailed discussions of the selected cleanup alternative. The cleanup, as implemented at the site, was governed by the approved project Work Plans. A number of variances from the approved project Work Plans occurred in response to field conditions and as a result of efforts to maximize the efficiency, performance, and cost-effectiveness of the cleanup. A list of these variances, including the rationale and justification for each change, is presented in Appendix A. Significant variances are also discussed in the text.

A total of five separate laboratories were used to conduct the analyses described in this report. The initial laboratory selected was unable to perform the analytical method specified for TPH in the Rulison QAPP (DOE, 1995d) (modified SW-846 Method 8015A). Instead, the laboratory used EPA Method 418.1 for the TPH analyses. While Method 418.1 is able to quantitate TPH concentrations at levels significantly below the cleanup criteria specified in the Rulison CAP (DOE, 1995a), it generally is not capable of distinguishing between gasoline, diesel, and other forms of TPH. Use of this laboratory was discontinued after the funds allocated to it for analyses were exhausted. The TPH concentrations determined using Method 418.1 are indicated as "nonspecific TPH" on the tables presented in this report. 


\subsection{Pond Draining and Construction Dewatering}

Prior to draining the pond, a dam was constructed to divert surface water flow from the spring to Hayward Creek using a flexible 10-centimeter $(\mathrm{cm})$ (4-inch [in.]) high-density polyethylene (HDPE) pipe (Figure 3-1). For the initial pond draining effort, two pumps were used with floating intakes, and the discharge was routed to the riprap slope of the pond outfall, outside the southwest corner of the pond berm. The discharge was routed to the riprap rather than directly to the adjacent stream to minimize the potential for stream erosion. The pond dewatering pumps were operated continuously for five days; then a third, smaller volume pump was added. The three pumps were operated continuously for another three days, at which time the water level in the pond became low enough to cause concern about picking up contaminated sediments if pumping was continued at a high rate. The two original pumps were then removed, and the third, lower volume pump was operated intermittently at low pumping rates. The pond was completely drained approximately 12 days after the two pumps were removed. Approximately $14,025,000$ liters $(3,705,000$ gallons $)$ of water were pumped from the pond.

During the initial days of the pond draining activity, an attempt was made to capture the fish in the pond and transplant them to the adjacent stream and beaver ponds. Recreational fishing tackle with barbless lures was used to capture the fish. A total of 25 fish were captured and transplanted to the stream and beaver ponds. An additional 10 to 15 fish were found in the pond after it was completely drained. No State-listed tiger salamanders were observed in the pond during or after the pond-draining activity. Once the pond was drained, stabilization and removal of the contaminated sediments was initiated (see Section 3.2).

Once removal of the sediments began, the floor of the pond was quickly lowered to below the static groundwater level. To control the groundwater, a construction dewatering trench was . excavated into the pond floor along the southeast berm, the hydraulically upgradient side of the pond (Figure 3-1). A water sample was collected from the trench before pumping began to determine whether treatment was necessary before discharge (see Section 3.1.1). Based on the analytical results of the sample, it was determined that treatment was not necessary, and the groundwater was pumped from the trench intermittently (and at varying pumping rates) each day and discharged to the riprap overflow channel located outside of the southwest corner of the pond.

Discharge of the pond water and construction dewatering effluent to the adjacent stream was permitted by the Colorado Department of Public Health and Environment under the Colorado Water Quality Control Act (Permit Number COG-310084, as modified). The permit also 


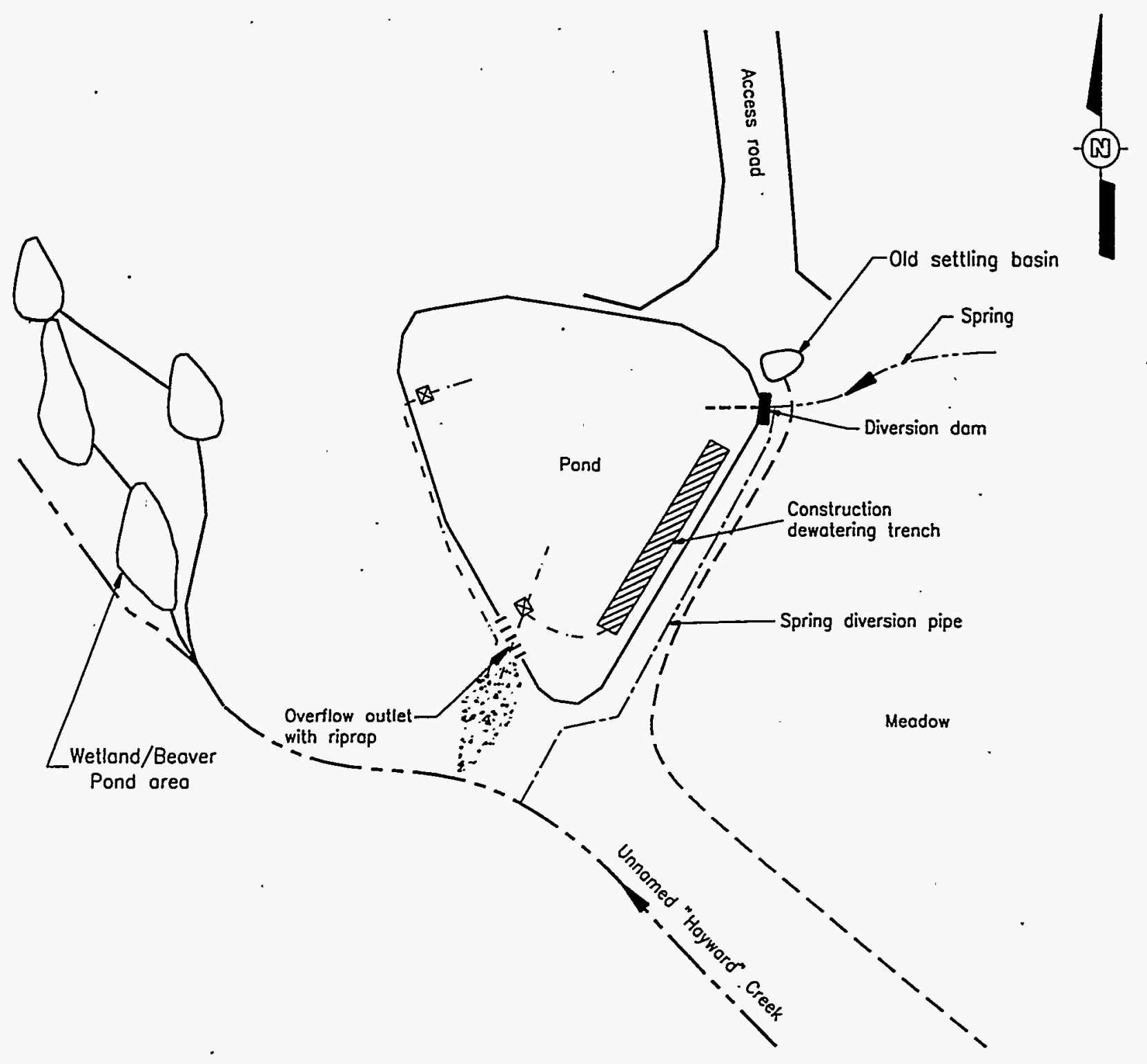

SCHEMATIC

NOT TO SCALE

LEGEND

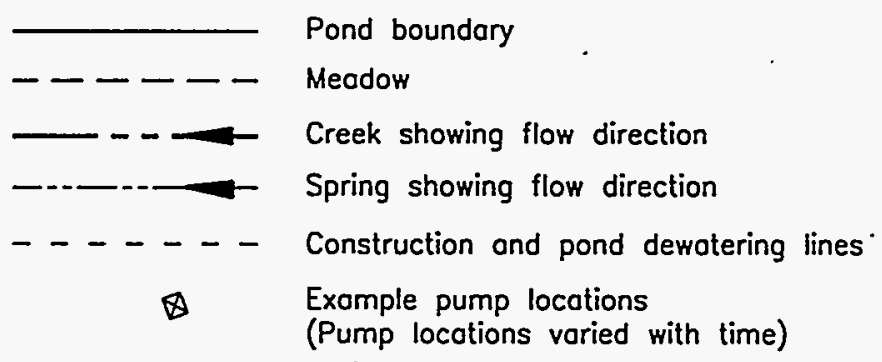

Figure 3-1

Rulison General Site Layout Diagram

Pond Water Discharge System 
specified the analytes and sampling frequency for discharge monitoring, which superseded what was specified in the Rulison CAP (DOE, 1995a) and VSAP (DOE, 1995b). The permit is included in Appendix B.

\subsubsection{Pond Draining and Construction Dewatering Analytical Results}

The pond water discharge was sampled three times as required by the water discharge permit: once at the beginning of the operation, once approximately five days after pumping started, and once after the two pumps were removed and the flow from the third pump was reduced. After the analytical results from the third sample were received, the laboratory was instructed to filter the remaining sample volume and reanalyze it for chromium and iron to determine whether those metals, which exceeded permit criteria in the original unfiltered sample, were present as dissolved species. Both dissolved chromium and dissolved iron were below their respective discharge criteria in the reanalyzed sample.

The groundwater that infiltrated into the pond during sediment stabilization was sampled four times: twice from the ponded water before the dewatering trench was excavated, once from the dewatering trench before pumping began to determine if treatment was required before discharge, and once from the dewatering pump discharge.

Pond water and construction dewatering discharge sampling was conducted in accordance with the Rulison VSAP (DOE, 1995b) and QAPP (DOE, 1995d). The analytical data from these samples are presented in Table 3-1 and Appendix $\mathrm{C}$ along with a list of the discharge criteria for the analytes specified under the permit. The analytical results were communicated to the CDPHE Water Quality Control Division (WQCD) in Discharge Monitoring Reports during the field work. Results of the samples indicated exceedances of several permit discharge criteria. These exceedances were discussed with the CDPHE WQCD by the DOE, with the result that no enforcement action is pending or forthcoming, as documented in the correspondence included in Appendix C.

The sample digestion procedure used by the laboratory for chromium, iron, and zinc analyses was not the procedure normally used for total recoverable metals analyses (SW-846 Method 3005A, "Acid Digestion of Waters for Total Recoverable or Dissolved Metals Analysis by FLAA or ICP Spectroscopy"). A microwave digestion procedure was used for total recoverable metals analyses (SW-846 Method 3015, "Microwave-Assisted Acid Digestion of Aqueous Samples and Extract"). The microwave digestion procedure uses a stronger acid than the standard total recoverable metals procedure, so the concentrations reported for chromium, iron, and zinc are at least as high as, if not:higher than, the total recoverable concentrations of those analytes in the samples. 
Table 3-1

\section{Pond Draining and Construction Dewatering Analytical Results}

\begin{tabular}{|c|c|c|c|c|c|c|c|c|c|}
\hline & & \multicolumn{8}{|c|}{ Pond Dewatering Samples } \\
\hline IT Corp ID\#| & Permit Criterion & RU00100 & & RU00102 & & RU00115 & & RU00115 & \\
\hline Date Collected & & $8 / 2 / 95$ & & $8 / 7 / 95$ & & $8 / 11 / 95$ & & $8 / 11 / 95$ & \\
\hline Sample Location & & Pond Water & & Pond Water & & Pond Water & & Reanalysis & \\
\hline & & Conc. & $\mathbf{Q}$ & Conc. & Q & Conc. & $\mathbf{Q}$ & Conc. & $\mathbf{Q}$ \\
\hline METALS: $\because \cdots \cdots$ & $\because \Leftrightarrow$ & $\because j \mathrm{ig} / \mathrm{\ddots}$ & $\because \because$ & $\because \mu g / \sigma_{0}$ & $\because$ & $\because \because \mu \mathrm{g} / \mathrm{L}$ & $\because \because$ & $\because \mu \mathrm{g} / \mathrm{L} \because \cdots$ & \\
\hline Chromium & 50 & 3.3 & U & 4.4 & $B$ & 131 & & 35.9 & \\
\hline Iron & 1000 & 201 & & 113 & & 1660 & & 84.1 & \\
\hline Dissolved Lead ${ }^{\mathrm{a}}$ & 31 & 2.0 & $u$ & 2.0 & $u$ & 7.6 & & na & \\
\hline Mercury & 2 & 0.20 & U & 0.20 & $\mathrm{U}$ & 0.20 & $\mathrm{U}$ & na & \\
\hline Zinc & 10 & 6.8 & & 4.0 & & 20.2 & & na & \\
\hline ORGANICS:b & igil & $\because 19 \pi \because$ & $\because$ & $\because j g \because$ & $\because$ & $\because \mu i t$ & $\because$ & $\because \mu \mathrm{g} \pi$ & \\
\hline Benzene & 1 & 1 & $\mathrm{U}$ & 1 & U & 1 & $\mathrm{U}$ & na & \\
\hline Toluene & NS & 5 & $U$ & 5 & $\mathrm{U}$ & 5 & $\mathrm{U}$ & na & \\
\hline Elhylbenzene & NS & 5 & U & 5 & $\mathrm{u}$ & 3 & $J$ & na & \\
\hline Tolal Xylene & NS & 5 & $\mathrm{U}$ & 5 & $\mathrm{U}$ & 6 & $\mathrm{~J}$ & na & \\
\hline Organic Toxic Pollutants & NS & & & & & $\mathrm{ND}^{*}$ & & na & \\
\hline TPH: $\quad \because \quad \because \because \because \cdots$ & $\because \because \because \because \mathrm{m}$ g $/[-\because \because \because \cdots$ & $\because \because \mathrm{mg} \Omega$ & $\because \because$ & $\because \because \operatorname{mig} \because \because \because$ & $\because$ & $\because \because \operatorname{mg} / \Omega$ & $\because \because$ & $\because \because \operatorname{mg} \Omega$ & \\
\hline Nonspecific & 10 & 5.0 & UJ & 0.5 & Uu & 6.46 & & na & \\
\hline Diesel & 10 & na & & na & & na & & na & \\
\hline INORGANICS: $\because$ & $\therefore \because$ mg $t$ t $\because \because$ & $\because$ ing & $\because \because$ & $\because$ mid & $\because$ & $\because \because \operatorname{mg} / L$ & $\because$ & $\because \mathrm{mg} / \mathrm{l}$ & $\because$ \\
\hline Tolal Dissolved Solids & NS & 380 & & 393 & & 380 & & na & \\
\hline Total Suspended Solids & $30 / 45^{c}$ & 4.0 & & 3.0 & & 49.0 & & na & \\
\hline $\mathrm{pH}$ & $6.5-9.0$ & 8.2 & & 8.1 & & 7.8 & & na & \\
\hline
\end{tabular}

\begin{tabular}{|c|c|c|c|c|c|c|c|c|c|}
\hline & & \multicolumn{8}{|c|}{ Construction Dewatering Samples } \\
\hline IT Corp ID\# & Permit Criterion & RU-CDW-01 & & RU-CDW-03 & & RU-CDW-05 & & RU-CDW-06 & \\
\hline Date Collected & & $9 / 15 / 95$ & & $9 / 15 / 95$ & & $9 / 27 / 95$ & & $10 / 5 / 95$ & \\
\hline Sample Location & & Pond Water & & Pond Water & & Pond Water & & Pond Water & \\
\hline & & Conc. & $\overline{\mathbf{Q}}$ & Conc. & & Conc. & & Conc. & \\
\hline$\because \because \because \because$ & $\because \cdots \lg 12 \because \cdots$ & $\because \mu g / 2 \therefore$ & $\because \because$ & $\because \mu g \Omega \because \cdots$ & & $\because \because$ ig/ $\therefore \because \because$ & $\because \because$ & $\because \because \mu g / \Omega \because \because$ & $\because$ \\
\hline Chromium & 50 & na & & na & & 10 & $\mathrm{U}$ & 13 & \\
\hline iron & 1000 & na & & na & & 660 & & 4100 & \\
\hline Dissolved Lead ${ }^{a}$ & 31 & na & & na & & 31 & $\mathrm{u}$ & 31 & U \\
\hline Mercury & 2 & na & & na & & 0.20 & $\mathrm{U}$ & na & \\
\hline Zinc & 10 & na & & na & & 20 & $\mathrm{U}$ & 28 & \\
\hline ORGANICS: ${ }^{t}, \therefore$ & agh & $\because \mu g i$ & & $\mathrm{ight}$ & & $\mu$ & $\because$ & iegi & $\because \because$ \\
\hline Benzene & 1 & 5 & $\mathrm{U}$ & 2 & U & 1.0 & $\mathrm{U}$ & 5.0 & U \\
\hline Toluene & NS & na & & na & & 0.40 & $\mathrm{~J}$ & 0.18 & $\mathrm{~J}$ \\
\hline Ethylbenzene & NS & na & & na & & 0.14 & $\mathrm{~J}$ & 0.18 & $\mathrm{~J}$ \\
\hline Total Xylene & NS & na & & na & & 0.80 & $\mathbf{J}$ & 25 & $\mathrm{U}$ \\
\hline Organic Toxic Pollutants & NS & na & & na & & ND* & & & \\
\hline TPH: $\because, \cdots \therefore \because \cdots$ & $\therefore \because \mathrm{mg} / \mathrm{t} \quad \because \because \because$ & $\because \because \mathrm{mg} d \mathrm{~L} \because \because$ & $\because$ & $\because$ mg $l i \because \because$ & $\because$ & $\because$ mg & $\because$ & $\therefore \because$ mgli $\because \because \because$ & $\therefore$ \\
\hline Nonspecific & 10 & na & & na & & 1.0 & U & na & \\
\hline Diesel & 10 & na & & na & & na & & 0.44 & \\
\hline INORGANICS; $\quad \ldots \cdots \cdots$ & $\because$ mgnd $\because \cdots$ & $\therefore \because \mathrm{mg} / \mathrm{L}: \because$ & $\because \because$ & $\because$ imgln $\because \because$ & $\because$ & $\because$ ing $\Omega$ & $\because$ & $\because$ ingl $\because \because$ & $\because$ \\
\hline Total Dissolved Solids & NS & na & & na & & 380 & & 570 & \\
\hline Total Suspended Solids & $30 / 45^{c}$ & na & & na & & 14 & & 140 & \\
\hline $\mathrm{pH}$ & $6.5-9.0$ & na & & па & & 7.7 & & 7.5 & $\mathrm{~J}$ \\
\hline
\end{tabular}

$Q=$ Data qualifier: $U$ = Compound was analyzed but not detected above the specified limit; $J=$ Reported value is estimated. $\mathrm{mg} / \mathrm{L}=$ milligrams per liter; $\mu \mathrm{g} / \mathrm{L}=$ micrograms per liter

$\mathrm{na}=$ not analyzed; $\mathrm{ND}^{*}=$ not detected. See Table B-2 for analytical quantitation limits..

NS $=$ not specified

\footnotetext{
${ }^{a}$ Dissolved Lead analysis required under the discharge permit.

bermit criterion for Total BTEX (benzene, toluene, ethylbenzene, and $x y l e n e s$ ) $=100 \mathrm{ug} / \mathrm{L}$

${ }^{c} 30 / 45 \mathrm{mg} / \mathrm{L}$ refers to 30 day average $/ 7$ day average
} 


\subsection{Pond Sediment Stabilization and Removal}

Stabilization and removal of the contaminated pond sediments began once the pond was drained. Before beginning the full-scale sediment excavation and stabilization operation, tests were conducted at the site to determine the type of stabilizer to be used. These tests consisted of mixing cement and kiln dust with samples of the pond sediment and then testing the stabilized sediment for free liquids (using the paint filter test) and for $\mathrm{pH}$ to determine which stabilizer would be the most effective in binding up excess water. The results of this testing showed that kiln dust was as effective in stabilizing the sediments as cement and was considerably less costly than cement, so kiln dust was selected as the stabilizer. Both the cement and kiln dust were quite effective in absorbing free liquid, so it was decided that sediment drying or dewatering, as specified in the Rulison CAP (DOE, 1995a), was not necessary. It also was determined that mixing the stabilizer and sediment within the pond was more efficient and more cost-effective than using a pug mill. A pug mill was specified in the Rulison CAP (DOE, 1995a).

The stabilization and removal process generally progressed from east to west across the pond. Large track hoes were used to mix and excavate the initial (uppermost) "lift" of pond sediment to a depth where firm soils were encountered (approximately 1.2 to $1.8 \mathrm{~m}$ [4 to $6 \mathrm{ft}$ ] deep). Firm soil was considered to represent the pre-disposal pond floor (i.e., "native" soil) and was thought to be uncontaminated. The excavated material was thoroughly mixed in place using kiln dust as a stabilizer, with a kiln-dust-to-sediment volumetric mixing ratio of approximately 1:9. Once the sediment and kiln dust were thoroughly mixed; samples of the stabilized sediment were collected and analyzed for TPH, Toxicity Characteristic Leaching Procedure (TCLP) chromium, and TCLP benzene, at the frequency specified in the Rulison VSAP (DOE; 1995b). At the direction of the DOE Site Manager, some stabilized sediment samples were also analyzed for radionuclides during the initial stages of the removal operation. The objectives of the radiological analyses were to verify that the drilling mud was not contaminated with radionuclides resulting from the nuclear test, and to address potential public concerns about the presence of radiological contamination at the site. Radionuclide analyses were discontinued after the results from the first samples collected indicated that there were no radionuclides present in the stabilized sediments above natural background levels. The analytical results for the stabilized sediment samples are included in Appendix D. After mixing, the stabilized sediments were left in the pond to set up for one or two days before being transferred to a stockpile located north of the pond. The stockpile was then sampled and the stabilized sediments stored pending return of the analytical results. After the analytical results were received, the stabilized sediments were loaded from the stockpile into dump trucks and transported to the South Canyon Landfill for disposal. As each dump truck was being loaded, a sample was collected and analyzed for free liquids (using the 
paint filter test) and for $\mathrm{pH}$ to ensure that the load met landfill acceptance criteria (passing the paint filter test, and a pH of between 2 and 12) before the truck was released from the site. All TPH, TCLP chromium, TCLP benzene, paint filter, and $\mathrm{pH}$ results met landfill disposal criteria.

After the initial lift of stabilized sediment was removed from the pond, the verification sample grid was established as specified in the Rulison VSAP (DOE, 1995b), and cleanup verification samples were collected (see Section 3.2.1). Excavation, stabilization, and removal of additional lifts of contaminated soil was conducted in areas where cleanup verification sample data or field observation indicated that contamination above cleanup criteria remained in the soils. Each additional lift of sediment removed was approximately 2 feet in thickness. After removal of each additional lift of stabilized soil, the verification sample grid was reestablished and cleanup verification samples were collected. This process continued until the results of the verification samples showed that the cleanup criteria had been met. In total, 1,923 cubic meters $\left(\mathrm{m}^{3}\right)$ $\left(2,384\right.$ cubic yards $\left.\left[\mathrm{yd}^{3}\right]\right)$ of kiln dust were used to stabilize the sediment, and $18,656 \mathrm{~m}^{3}$ $\left(24,400 \mathrm{yd}^{3}\right)$ of stabilized sediment and soil were hauled to the landfill. The total volume of stabilized sediment transported to the landfill significantly exceeded the volume estimated in the Rulison VSAP (DOE, 1995b) because the depth of contamination exceeding cleanup criteria was greater than estimated.

\subsubsection{Cleanup Verification Analytical Results}

At the direction of the CDPHE representative overseeing the cleanup, the 37 cleanup verification soil sample locations proposed in the Rulison VSAP (DOE, 1995b) were augmented by 18 additional soil sample points. In addition, test pits were excavated at six locations along the pond berm to assess whether contamination was present in the berm soils. One cleanup verification sample location could not be sampled (location 39) because it was covered by infiltrating groundwater after the contaminated sediment was removed. Because the verification samples collected from locations adjacent to Location 39 were all below cleanup criteria, it was decided in the field that a sample from Location 39 was not necessary to demonstrate that cleanup goals for the pond had been met. The verification sample locations are shown on Figure 3-2.

The initial cleanup criteria used for the contaminants of concern in the pond sediments, as described in Section 3.7 of the Rulison CAP (DOE, 1995a), were 250 milligrams per kilogram . (mg/kg) for TPH, $100 \mathrm{mg} / \mathrm{kg}$ for chromium, $100 \mathrm{mg} / \mathrm{kg}$ for lead, and 2,000 mg/kg for barium. The DOE entered into a series of negotiations with the CDPHE representative to raise the cleanup criterion for TPH in order to limit the amount of sediment and native soil requiring 


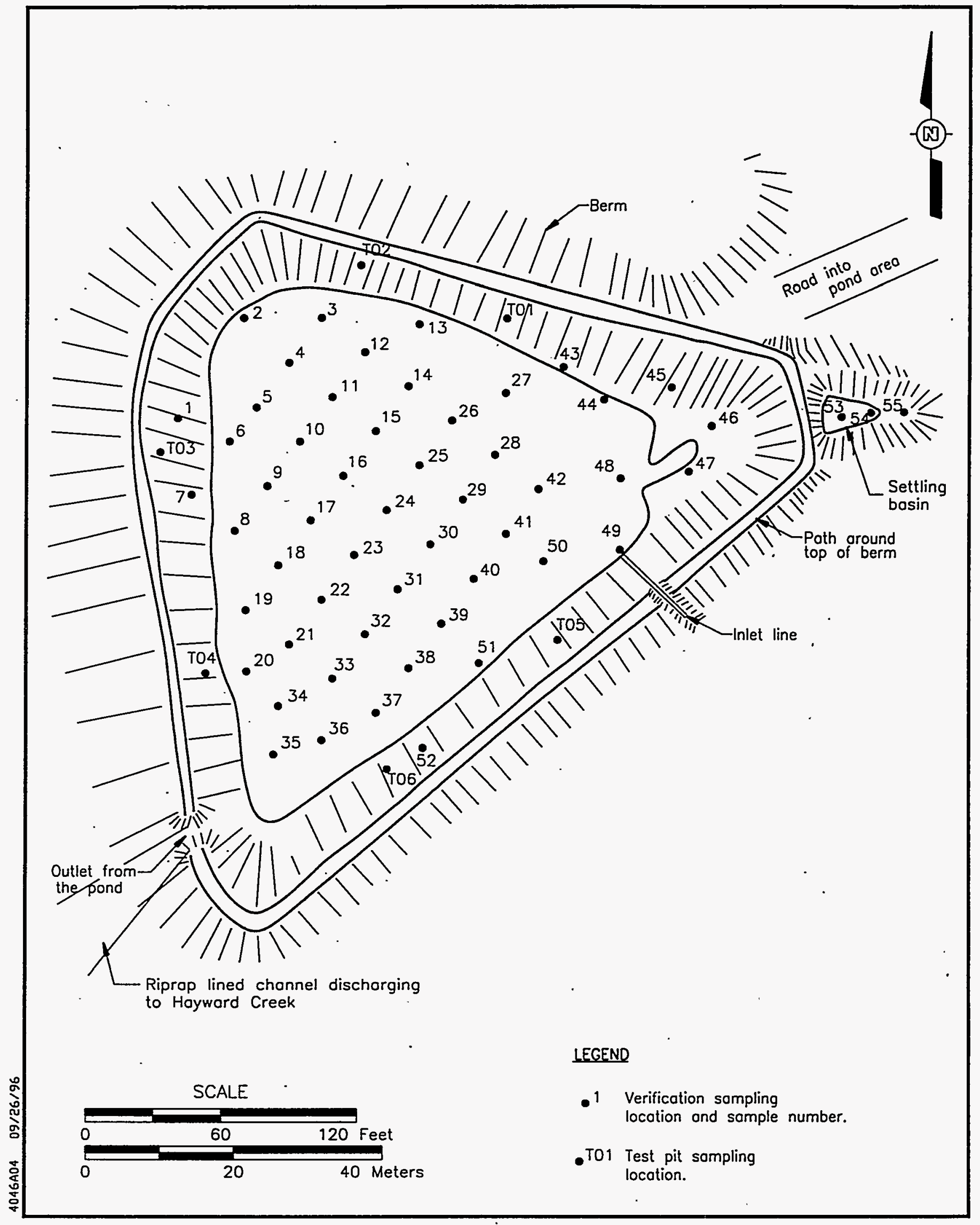

Figure 3-2

Rulison Drilling Effluent Pond

Verification Soil Sampling Locations 
stabilization and removal, thus reducing the cost of the cleanup action. On October 17, 1995, the CDPHE representative overseeing the cleanup verbally authorized an increase in the TPH cleanup criterion to $1,000 \mathrm{mg} / \mathrm{kg}$, to be supported by a risk assessment and an estimate of the area and volume of sediments remaining with TPH concentrations exceeding $250 \mathrm{mg} / \mathrm{kg}$. A followup written notification from the CDPHE approving the $1,000 \mathrm{mg} / \mathrm{kg}$ TPH cleanup criterion variance was received by DOE on June 7, 1996. The written notification is included in Appendix E. This revised criterion was used to delineate the limits of excavation for the sediment and native soil removal.

All cleanup verification samples were analyzed for TPH, as specified in the Rulison VSAP (DOE, 1995b). The instructions used by field sampling personnel during verification sampling specified that samples were to be analyzed for TCLP benzene and TCLP metals, rather than for total concentrations of those contaminants as specified in the Rulison.VSAP (DOE, 1995b). As a result, there are no cleanup verification analytical data available for total chromium, lead, and barium to compare against the cleanup criteria identified in the Rulison CAP (DOE, 1995a), although there are data for TCLP chromium, lead, and barium. However, pond sediment analytical data from the 1994 and 1995 sampling events suggest that TPH contamination and chromium contamination are correlated, in that there were no pond sediment samples that showed exceedence of the chromium cleanup criterion without a corresponding exceedence of the $1,000 \mathrm{mg} / \mathrm{kg}$ TPH criterion. As a consequence, TPH concentrations are considered to be an adequate indicator of whether the soils remaining in the pond meet the cleanup criteria for the metals.

As. described in Section 3.2, cleanup verification samples were collected after each lift of stabilized sediment or native soil was removed. The TPH and TCLP chromium results for all cleanup verification samples are presented in Table 3-2, and all cleanup verification sample results, including TCLP metals and TCLP benzene data, are included in Appendix E. In these tables, the verification samples collected after removal of the original lift of contaminated sediment are numbered RU-VSS-xx, where $x x$ is the sample location (see Figure 3-2). Locations where contamination above cleanup criteria remained after removal of the original lift were resampled after removal of each additional lift. These samples are numbered RU-VSS-xx-y, where $y$ is the additional lift number. Samples numbered RU-VSS-xx-12 are duplicates of the samples collected at location(s) $\mathrm{xx}$, and samples numbered RU-VSS-2xx are split samples collected at location(s) $\mathrm{xx}$ at the request of the CDPHE representative. The test pit samples are numbered RU-Txx-yy, where xx is the test pit number (see Figure 3-2) and yy is the depth (in inches) at which the samples were collected (several samples were collected from each test pit). 
Table 3-2

Pond Cleanup Verification Analytical Results Total Petroleum Hydrocarbons, Toxicity Characteristic Leaching Procedure Chromium

(Page 1 of 2)

\begin{tabular}{|c|c|c|c|c|c|c|c|}
\hline Sample ID\# & RU-VSS-01 & RU-VSS-01-1 & RU-VSS-01-2 & RU-VSS-02 & RU-VSS-02-1' & RU.VSS-03-1 ${ }^{1}$ & RU-VSS-04-1' \\
\hline Date Collected & $97 / 95$ & $9 / 9 / 95$ & $10 / 13 / 95$ & 97195 & $9 / 9195$ & 9/9/95 & $9 / 9 / 95$ \\
\hline Sample Location & Pond Floor & Pond Floor & Pond Floor & Pond Floor & Pond Floor & Pond Floor & Pond Floor \\
\hline & mgikg & inmekg & IIImq/kghth & Gis me/kghol & Whing/kgin: & :Ijong/kg id & mamg/ / / \\
\hline TPH-Nonspecific & na & $1021 \mathrm{~J}$ & $\mathrm{na}$ & na & $700 \mathrm{~J}$ & $70 \mathrm{~J}$ & $685 \mathrm{~J}$ \\
\hline TPH-Diesel & 1.600 & na & 22 & 1.700 & $\mathrm{na}$ & na & na \\
\hline TPH-Waste Oil & na & $\mathrm{na}$ & na & $\mathrm{na}$ & $\mathrm{na}$ & na & $n a$ \\
\hline $\mathrm{TCLP} \operatorname{Cr}(\mathrm{m} \Omega /)$ & na & na & na & na & na & na & na \\
\hline
\end{tabular}

\begin{tabular}{|c|c|c|c|c|c|c|c|}
\hline Sample IDH & RU-VSS-04-2 & RU-VSS-05-1 $1^{1}$ & RU-VSS-05-2 $2^{2}$ & RU-VSS-06-1 ${ }^{2}$ & RU.VSS-07.-1 ${ }^{1}$ & RU-VSS-08 & RU.YSS-08-1' \\
\hline Date Collected & $10 / 13 / 95$ & $9 / 9 / 95$ & $10 / 13 / 95$ & $9 / 9 / 95$ & $9 / 9 / 95$ & $9 / 195$ & $9 / 9 / 95$ \\
\hline Sample Location & Pond Floor & Pond Floor & Pond Floor & Pond Floor & Pond Floor & Pond Floor & Pond Floor \\
\hline & mgkghIII & III! $\mathrm{me} / \mathrm{kg}$ & APing/kg III & WII $\mathrm{kg} / \mathrm{kg} / \mathrm{l}$ & WhtI nigkg!I! & 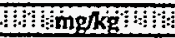 & Bhmokgum \\
\hline TPH-Nonspecific & na & $590 \mathrm{~J}$ & na & $138 \mathrm{~J}$ & $310 \mathrm{~J}$ & na & $100 \mathrm{~J}$ \\
\hline TPH-Diesel & 160 & $\mathrm{na}$ & 33 & na & na & 260 & na \\
\hline TPH-Waste Oil & na & $\mathrm{na}$ & $\mathrm{na}$ & na & na & na & $\overline{\mathbf{n a}}$ \\
\hline $\mathrm{TCLPC}_{\mathrm{r}}(\mathrm{m} \mathrm{m} / \mathrm{L})$ & $\overline{\text { na }}$ & $0.0033 \mathrm{U}$ & $0.10 \mathrm{U}$ & na & na & $0.0033 \mathrm{U}$ & na \\
\hline
\end{tabular}

\begin{tabular}{|c|c|c|c|c|c|c|c|}
\hline Sample ID\#ت & RU.VSS-09 & RU-VSS-10-1' & RU.VSS.11-1 ${ }^{1}$ & RU-YSS-12 & RU-VSS-13 & RU-VSS-13-1 & RU-VSS-14 \\
\hline Date Collected & $9 / 7 / 95$ & $9 / 9 / 95$ & $9 / 9 / 95$ & $10 / 13 / 95$ & $10 / 14 / 95$ & $10 / 19 / 95$ & $10 / 13 / 95$ \\
\hline Sample Location & Pond Floor & Pond Floor & Pond Floor & Pond Floor & Pond Floor & Pond Floor & Pond Floor \\
\hline & $\mathrm{mg} / \mathrm{kg}$ & $: \mathrm{mi} / \mathbf{k g : A l s}$ & (1:mq/kg:1II & Pringkg & Himgkg & Himefg in & img/kg!| \\
\hline TPH-Nonspecific & $\mathrm{na}$ & $176 \mathrm{~J}$ & $177 \mathrm{~J}$ & na & $\mathrm{na}$ & na & $\mathrm{na}$ \\
\hline TPH-Diesel & 49 & $\mathrm{na}$ & na & 320 & $2600 \mathrm{D}$ & 840 & 7.1 \\
\hline TPH-Waste Oil & $\mathrm{na}$ & na & na & na & $25 \mathrm{U}$ & $n a$ & na \\
\hline$\overline{T C L P C r}(\mathrm{mg} / \mathrm{L})$ & na & na & $\mathrm{na}$ & $\mathrm{na}$ & na & $\mathrm{na}$ & na \\
\hline
\end{tabular}

\begin{tabular}{|c|c|c|c|c|c|c|c|}
\hline Sample [D\#] & RU.VSS-15 ${ }^{1}$ & RU-VSS.16 & RU.VSS-17 & RU-VSS-18 & RU-VSS-19 & RU-VSS-19-1 & RU.VSS.20 \\
\hline Date Collected & $10 / 13 / 95$ & $10 / 12 / 95$ & $10 / 12 / 95$ & $10 / 12 / 95$ & $10 / 12 / 95$ & $10 / 18 / 95$ & $10 / 12 / 95$ \\
\hline Sample Location & Pond Floor & Pond Floor & Pond Floor & $\begin{array}{l}\text { Pond Floor } \\
\end{array}$ & Pond Floor & Pond Floor & Pond Floor \\
\hline & mglkg: & : ma/kg : & 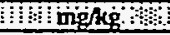 & Htimg $\mathrm{kg}$ & 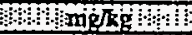 & 61) Imo/kg : I & DIIImg/kgl|!। \\
\hline TPH-Nonspecific & $\mathrm{na}$ & na & $\mathrm{na}$ & \begin{tabular}{|c|}
$\mathrm{na}$ \\
\end{tabular} & na & $\begin{array}{l}\mathrm{na} \\
\end{array}$ & na \\
\hline TPH-Diesel & 180 & $25 \mathrm{U}$ & 210 & 29 & 16.000 & 370 & 2.500 \\
\hline TPH-Wasle Oil & $\mathrm{na}$ & $25 \mathrm{U}$ & $25 \mathrm{U}$ & na & na & $\mathrm{na}$ & na \\
\hline TCLP Cr $(\mathrm{mg} / \mathrm{L})$ & $0.10 \mathrm{U}$ & na & na & na & $\mathrm{na}$ & na & $0.10 \mathrm{U}$ \\
\hline
\end{tabular}

\begin{tabular}{|c|c|c|c|c|c|c|c|}
\hline Sample ID\# & RU-VSS-20-1 & RU-VSS-20-2 & RU-VSS-21 & RU.VSS-22 & RU.VSS-23' & RU-VSS- $24^{1}$ & RU-VSS- $25^{1}$ \\
\hline Date Collected & $10 / 18 / 95$ & $10 / 21 / 95$ & $10 / 12 / 95$ & $10 / 12 / 95$ & $10 / 12 / 95$ & $10 / 12 / 95$ & $10 / 13 / 95$ \\
\hline Sample Location & Pond Floor & Pond Floor & Pond Floor & Pond Floor & Pond Floor & - Pond Floor & Pond Floor \\
\hline & $\mathrm{mg} / \mathrm{kg}$ & me/kg . . . & $\because \mathrm{mg} / \mathrm{kg}^{\prime} \mathrm{Gi}$ & $\mathrm{min} / \mathrm{kg} / \mathrm{O}$ & 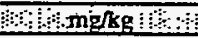 & mmg/kg in & $\because \cdot \mathrm{m} m \mathrm{~m} / \mathrm{kg}:$ \\
\hline TPH-Nonspecific & na & $\mathrm{na}$ & na & na & $\mathrm{na}$ & na & $\mathrm{na}$ \\
\hline TPH-Diesel & 1.500 & 150 & $2.4 \mathrm{U}$ & 370 & $25 \mathrm{U}$ & 170 & 680 \\
\hline TPH-Waste Oil & $\mathrm{na}$ & na & na & na & $25 \mathrm{U}$ & $25 \mathrm{U}$ & na \\
\hline TCLP Cr (mgl) & na & na & na & na & na & na & $0.10 \mathrm{U}$ \\
\hline
\end{tabular}

\begin{tabular}{|c|c|c|c|c|c|c|c|}
\hline Sample ID\# & RU.YSS-26 ${ }^{1}$ & RU.YSS-26-1 & RU.VSS-27 & RU-VSS-27-12 & RU-VSS-28 ${ }^{1}$ & RU.VSS. $29^{1}$ & RU-VSS-29-1 \\
\hline Date Collected & $10 / 13 / 95$ & $10 / 18 / 95$ & $10 / 14 / 95$ & $10 / 14 / 95$ & $10 / 13 / 95$ & $10 / 13 / 95$ & $10 / 18 / 95$ \\
\hline Sample Lacation & pond floor & pond floor & pond floor & pond floor & pond floor & pond floor & pond foor \\
\hline & $\mathrm{mg} / \mathrm{kg}^{-}$ & $\mathrm{mg} / \mathrm{kg}$ & mipkg & emg $\mathrm{kg} M$ & Hसid $k \mathrm{~kg}$ & Himikginth & img/kg : I \\
\hline TPH-Nonspecific & na & na & na & na & $\mathrm{na}$ & $\begin{array}{c}\mathrm{na} \\
\end{array}$ & na \\
\hline TPH-Diesel & 1.400 & 31 & 160 & 740 & 77 & $2000^{2}$ & 77 \\
\hline TPH-Waste Oil & $\mathrm{na}$ & $\mathrm{na}$ & $25 \mathrm{U}$ & na & na & $\mathrm{na}$ & na \\
\hline $\operatorname{TCLPCr}(\mathrm{mg} / \mathrm{L})$ & na & $\mathbf{n a}$ & $0.0037 \mathrm{U}$ & 0.100 & na & $\mathrm{na}$ & na \\
\hline
\end{tabular}

\begin{tabular}{|c|c|c|c|c|c|c|c|}
\hline Sample ID\# & RU-YSS-30' & RU-VSS-31 & RU-VSS-32 & RU-VSS-33 & RU-VSS-34 & RU-YSS-34-1 & RU-VSS-34-2 \\
\hline Date Collected & $10 / 12 / 95$ & $10 / 12 / 95$ & $10 / 12 / 95$ & $10 / 12 / 95$ & $10 / 12 / 95$ & $10 / 18 / 95$ & $10 / 21 / 95$ \\
\hline Sample Location & Pond Floor & Pond Floor & Pond Floor & Pond Floor & Pond Floor & Pond Floor & Pond Floor \\
\hline & mgkg & $\mathrm{mg} / \mathrm{kg}$ & $\cdots$ ng kg & ting/kg & 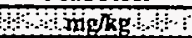 & $\mathrm{mimg/kg}$ & imimg \\
\hline TPH-Nonspecific & $\mathrm{na}$ & na & $\mathrm{na}$ & na & $\mathrm{na}$ & $\begin{array}{l}\text { na } \\
\end{array}$ & $\mathrm{na}$ \\
\hline TPH-Diesel & 36 & $30^{2}$ & 170 & 340 & 1.400 & 1,700 & 140 \\
\hline TPH-Waste Oil & $25 \mathrm{U}$ & $\mathrm{na}$ & na & na & na & na & na \\
\hline TCLPCr $(\mathrm{m} \Omega /)$ & 0.00370 & $\mathrm{na}$ & na & $\mathrm{na}$ & $\overline{n a}$ & $\mathrm{na}$ & $\mathrm{na}$ \\
\hline
\end{tabular}


Table 3-2

Pond Cleanup Verification .Analytical Results Total Petroleum Hydrocarbons, Toxicity Characteristic Leaching Procedure Chromium

(Page 2 of 2)

\begin{tabular}{|c|c|c|c|c|c|c|c|}
\hline Sample ID\# & RU-YSS-34-12 & RU-VSS-35' & RU.VSS-36 & RU-VSS-37 & RU.VSS-38 & RU-VSS-40 ${ }^{1}$ & RU.VSS $-41^{1}$ \\
\hline Date Collected & $10 / 14 / 95$ & $10 / 13 / 95$ & $10 / 12 / 95$ & $10 / 12195$ & $10 / 12 / 95$ & $10 / 12 / 95$ & $10 / 13 / 95$ \\
\hline Sample Location & Pond Floor & Pond Floor & Pond Floor & Pond Floor & $\begin{array}{l}\text { Pond Floor } \\
\end{array}$ & Pond Floor & Pond Floor \\
\hline 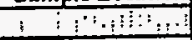 & $\mathrm{m} \mathrm{mg} / \mathrm{kg} \mathrm{mm}$ & ill: $\mathrm{mg} / \mathrm{kght}$ & hmokg mi: & Wtmg/kgls & PIPmg/kg & Oingkg:M & HImg/kg: \\
\hline TPH-Nonspecific & na & na & $\mathrm{na}$ & $\mathrm{na}$ & \begin{tabular}{|l} 
na \\
\end{tabular} & na & na \\
\hline TPH-Diesel & 310 & 600 & 590 & 72 & 540 & $25 \mathrm{U}$ & 240 \\
\hline TPH-Waste Oil & na & $\mathrm{na}$ & $\mathrm{na}$ & na & na & $25 \mathrm{U}$ & $\mathrm{na}$ \\
\hline TCLP Cr (m $/ 2)$ & $0.10 \mathrm{U}$ & $0.10 \mathrm{U}$ & na & na & na & $0.0058 \mathrm{U}$ & $0.10 \mathrm{U}$ \\
\hline
\end{tabular}

\begin{tabular}{|c|c|c|c|c|c|c|c|}
\hline Sample IDH & RU.VSS $-42^{1}$ & RU-VSS-43 & RU-VSS-44 & RU.VSS-45 & RU-VSS- 46 & RU-VSS-47 & RU-VSS-48 \\
\hline Date Collected & $10 / 13 / 95$ & $10 / 19 / 95$ & $10 / 19 / 95$ & $11 / 01 / 95$ & $11 / 01 / 95$ & $11 / 01 / 95$ & $10 / 19 / 95$ \\
\hline Sample Location & Pond Floor & $\begin{array}{l}\text { Pond Floor } \\
\end{array}$ & Pond Floor & Pond Floor & Pond Floor & $\begin{array}{l}\text { Pond Floor } \\
\end{array}$ & Pond Floor \\
\hline 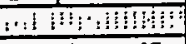 & Hmgkglit! & 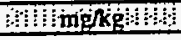 & th migkg & Stmigkg & 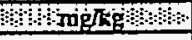 & Atmgkgist & ing/kg \\
\hline TPH-Nonspecific & \begin{tabular}{|c|}
$\mathrm{na}$ \\
\end{tabular} & \begin{tabular}{|l|} 
na \\
\end{tabular} & $\mathrm{na}$ & $\mathrm{na}$ & na & na & $\mathrm{na}$ \\
\hline TPH-Diesel & 49 & 170 & 470 & $45^{\circ}$ & 21 & 67 & 790 \\
\hline TPH-Waste Oil & $\mathrm{na}$ & $\mathrm{na}$ & na & na & na & na & na \\
\hline $\mathrm{TCLPCr}(\mathrm{mg} / \mathrm{L})$ & na & na & na & $\mathrm{na}$ & $\mathrm{na}$ & 0.100 & na \\
\hline
\end{tabular}

\begin{tabular}{|c|c|c|c|c|c|c|c|}
\hline Sample ID\# & RU.VSS $-49^{1}$ & RU.VSS $-49-12$ & RU-vSS-49-12S & RU-VSS-50 ${ }^{2}$ & RU-VSS-51 & RU.VSS.52 & RU-VSS-53 \\
\hline Date Collected & $10 / 13 / 95$ & $10 / 14 / 95$ & $10 / 14 / 95$ & $10 / 13 / 95$ & $10 / 12 / 95$ & $10 / 12 / 95$ & $11 / 6 / 95$ \\
\hline Sample Location & Pond Floor & Pond Floor & Pond Floor & Pond Floor & Pond Floor & Pond Floor & Pond Floor \\
\hline , & $\mathrm{mg} / \mathrm{kg} \mathrm{s}$ & flmokg & ind $k \mathrm{~kg} / \mathrm{s}$ & Golng ks & 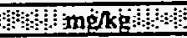 & Angkg & hीHmmkg \\
\hline TPH-Nonspecific & na & na & na & na & na & na & \begin{tabular}{|c|} 
na \\
\end{tabular} \\
\hline TPH-Diesel & 110 & 350 & 120 & 1.000 & 60 & $2.4 \mathrm{U}$ & 27 \\
\hline TPH-Waste Oil & $\mathrm{na}$ & na & $25 \mathrm{U}$ & na & $25 \mathrm{U}$ & na & na \\
\hline $\operatorname{TCLPCr}(\mathrm{m} / \mathrm{L})$ & na & $0.10 \mathrm{U}$ & $0.0048 \mathrm{~B}$ & $0.10 \mathrm{U}$ & $\mathrm{na}$ & $\mathrm{na}$ & $\mathrm{na}$ \\
\hline
\end{tabular}

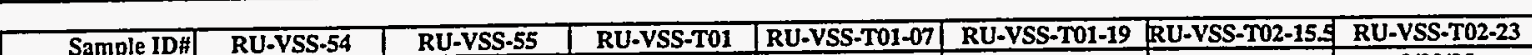

\begin{tabular}{|c|c|c|c|c|c|c|c|}
\hline Sample ID & RU.VSS-54 & RU-VSS-55 & RU.VSS-T01 & RU-VSS-T01-07 & RU-VSS-T01-19 & RU-VSS-T02-15.5 & RU-VSS-T02-23 \\
\hline Date Collected & $11 / 6 / 95$ & $11 / 6 / 95$ & $9 / 21 / 95$ & $9 / 21 / 95$ & $9 / 21 / 95$ & $9 / 20 / 95$ & $9 / 20 / 95$ \\
\hline Sample Location & pond floor & pond floor & Test Pit 01 & Test Pit 01 & Test Pit 01 & Test Pit 02 & Test Pit 02 \\
\hline $1: \div: 1: \cdots$ & timg $\mathrm{kg}$ & 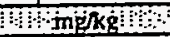 & Bang $/ \mathrm{g} n$ & Dी $\mathrm{mg} k \mathrm{~kg}$ & 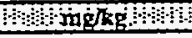 & Hni $/ \mathrm{kg} / \mathrm{all}$ & Homg/kg : \\
\hline TPH-Nonspecific & na & na & na & $\mathrm{na}$ & na & na & na \\
\hline TPH-Diesel & 60 & 38 & $\mathrm{na}$ & 300 & 330 & 20 & 40 \\
\hline TPH-Waste Oil & na & $\mathrm{na}$ & $\mathrm{na}$ & na & na & na & na \\
\hline $\mathrm{TCLPCr}(\mathrm{m} / \mathrm{L})$ & na & $\overline{n a}$ & $0.10 U$ & na & na & na & na \\
\hline
\end{tabular}

\begin{tabular}{|c|c|c|c|c|c|c|c|}
\hline Sample ID\# & RU-YSS-T02-31 & RU-VSS-T03-26 & RU-VSS-T03-39 & RU-VSS-T04 & RU-VSS-T04-14 & RU-VSS-T04-23 & RU-VSS-T05-14 \\
\hline Date Collected & $9 / 20 / 95$ & $9 / 20 / 95$ & $9 / 20 / 95$ & $9 / 21 / 95$ & $9 / 21 / 95$ & $9 / 21 / 95$ & $9 / 26 / 95$ \\
\hline Sample Location & Test Pit 02 & $\begin{array}{l}\text { Test Pit } 03 \\
\end{array}$ & Test Pit 03 & Test Pit 04 & Test Pit 04 & Test Pit 04 & Test Pit 05 \\
\hline 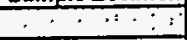 & 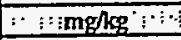 & mokg: & miskg & $\mathrm{amg} / \mathrm{kg} / \mathrm{a}$ & :म"me & mang $/ \mathrm{kg}$ & ing/kg \\
\hline TPH-Nonspecific & $\begin{array}{c}\text { na } \\
\end{array}$ & na & na & na & na & na & na \\
\hline TPH-Diesel & 4.4 & 56 & 41 & na & 3.500 & 3.100 & 200 \\
\hline TPH-Waste Oil & na & $\mathrm{na}$ & na & na & na & $\mathrm{na}$ & na \\
\hline $\operatorname{TCLPCr}(\mathrm{m} / \mathrm{L})$ & $\mathrm{na}$ & na & $\mathrm{na}$ & $0.10 \mathrm{U}$ & na & na & na \\
\hline
\end{tabular}

\begin{tabular}{|c|c|c|c|c|c|c|c|}
\hline Sample ID\# & RU.VSS-T05-24 & RU.VSS-T05-30 & RU.VSS-T06-7 & RU-VSS-T06-15 & RU-VSS-T06-22 & RU-VSS-205 & RU-VSS-215 \\
\hline Date Collected & $9 / 26 / 95$ & $9 / 26 / 95$ & $9 / 26 / 95$ & $9 / 26 / 95$ & $9 / 26 / 95$ & $10 / 13 / 95$ & $10 / 13 / 95$ \\
\hline Sample Location & Test Pit 05 & Test Pit 05 & Test Pit 06 & Test Pit 06 & $\begin{array}{l}\text { Test Pit 06 } \\
\end{array}$ & Pond Floor & Pond Floor \\
\hline$\therefore \quad i: \quad \therefore: 1, \quad 1$. & $4 \mathrm{mg} / \mathrm{kg}:$ & mikg & m $\mathrm{m} / \mathrm{kg}$ & makg & 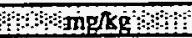 & bing/kg & Himg/kg : : \\
\hline TPH-Nonspecific & na & na & na & $\mathrm{na}$ & na & na & $\mathrm{na}$ \\
\hline TPH-Diesel & 14 & $2.5 \mathrm{U}$ & 23 & 45 & $2.1 \mathrm{U}$ & 30 & 240 \\
\hline TPH-Waste Oil & na & na & na & na & na & $25 \mathrm{U}$ & $25 \mathrm{U}$ \\
\hline $\operatorname{TCLPCr}(\mathrm{mg} / \mathrm{L})$ & na & na & na & $\mathrm{na}$ & $\overline{\mathrm{na}}$ & $0.020 \mathrm{U}$ & $0.0020 \mathrm{U}$ \\
\hline
\end{tabular}

\begin{tabular}{|c|c|c|c|c|c|c|c|}
\hline Sample IDH & RU-VSS-225 & RU-VSS-227 & RU-VSS-235 & RU-VSS-241 & RU-VSS-247 & RU-VSS-253 & RU-YSS-255 \\
\hline Date Collected & $10 / 13 / 95$ & $10 / 14 / 95$ & $10 / 13 / 95$ & $10 / 13 / 95$ & $11 / 1 / 95$ & $11 / 6 / 95$ & $11 / 6 / 95$ \\
\hline Sample Location & Pond Floor & Pond Floor & Pond Floor & Pond Floor & Pond Floor & Pond Floor & Pond Floor \\
\hline$\div: \cdots, \cdots$ & $\mathrm{mg} / \mathrm{kg}=\mathrm{:}$ & : : me/kg:1!r & :1:mgkg & omg/kg: & ismekg & mg/kg & img/kg : \\
\hline TPH-Nonspecific & na & na & \begin{tabular}{|c|}
$\mathrm{na}$ \\
\end{tabular} & na & na & na & na \\
\hline TPH-Diesel & 500 & 170 & 440 & 380 & 45 & $25 \mathrm{U}$ & $25 \mathrm{U}$ \\
\hline TPH-Waste Oil & $24 \mathrm{U}$ & na & $25 \mathrm{U}$ & $24 \mathrm{U}$ & $24 \mathrm{U}$ & $25 \mathrm{U}$ & $25 \mathrm{U}$ \\
\hline $\operatorname{TCLPCr}(\mathrm{mg} /)$ & 0.0218 & 0.100 & $0.020 \mathrm{U}$ & $0.020 \mathrm{U}$ & $0.020 \mathrm{U}$ & $\mathrm{na}$ & $\mathrm{na}$ \\
\hline
\end{tabular}

$\mathrm{U}=$ Compound was analyzed for but not detected above the specified limit

$\mathrm{J}=$ Reported value is estimated

$D=$ TPH Diesel concentration for RU.VSS- 13 is from a $1: 5$ dilution.

$B=$ Concentration is greater than the instrument detection limit but less than the contract required detection limit

$\mathrm{mg} / \mathrm{kg}=$ milligrams per kilogram: $\mathrm{mg} /=$ milligrams per liter

'Validated sample

'Mutrix interference experienced with this analyws

na $=$ not analyzed 


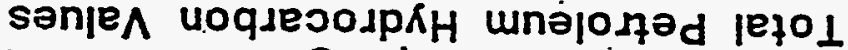

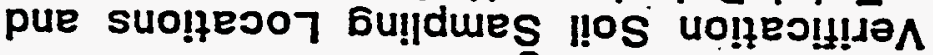

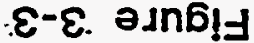

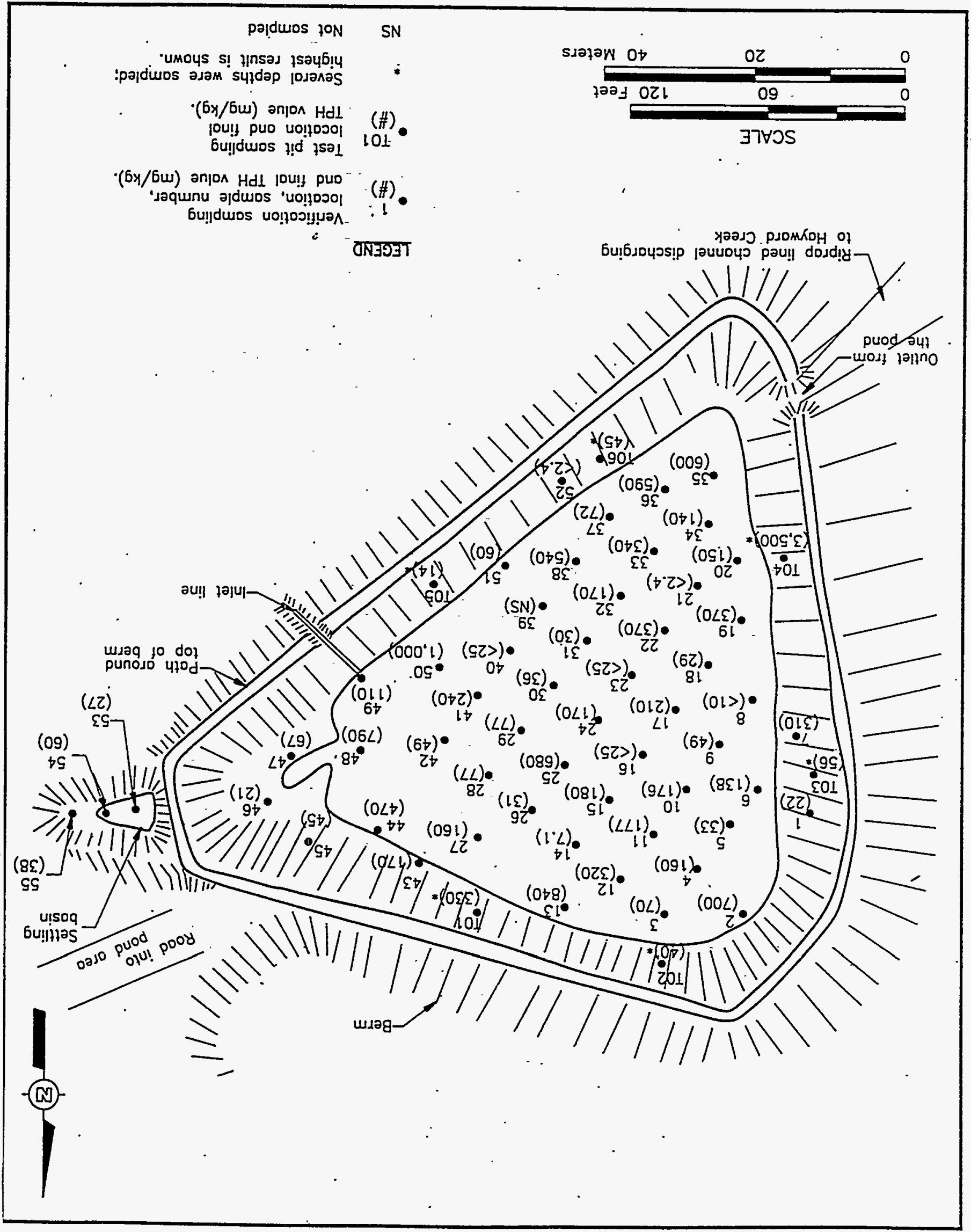


The TPH analytical results for the final (i.e., deepest) cleanup verification samples collected at each location are shown on Figure 3-3. With the exception of the samples from Test Pit T04, all final cleanup verification samples showed TPH concentrations equal to or less than the TPH cleanup criterion of $1,000 \mathrm{mg} / \mathrm{kg}$, thus demonstrating the pond cleanup goals were met.

Visual observation and field screening data from Test Pit T04 indicated that the TPH contamination appeared to be confined to a thin layer of drilling mud. The mud layer was removed through additional excavation; but an additional verification sample was not collected from that location. However, based on the visual observations and field screening data, it is thought that any TPH contamination remaining at the Test Pit T04 location is well below $1,000 \mathrm{mg} / \mathrm{kg}$.

\subsection{Pond Restoration}

Following verification that all soils remaining in the bottom and sides of the pond met the soil quality criteria specified for the site, the pond was restored in general accordance with Section 3.8 of the Rulison CAP (DOE, 1995a). The overall height of the berm was reduced, and material excavated from the top of the berm was used to backfill the pond. The pond was backfilled so the final depth was approximately $6 \mathrm{~m}$ ( $20 \mathrm{ft}$ ) below the top of the berm, and the pond sidewalls were graded to a 3:1 slope. A spillway was constructed at the southwest corner of the pond, approximately $4.3 \mathrm{~m}(14 \mathrm{ft})$ above the pond floor, to provide drainage from the pond. The elevation of the spillway was set at $3 \mathrm{~m}$ (10 ft) above the elevation of the ground surface at the toe of the outside slope of the berm to comply with Colorado Water Resources Division requirements for uncertified water retention structures. To ensure that the reconstructed pond is capable of retaining water, a Bentomat ${ }^{\circledR}$ geosynthetic clay liner was installed over the pond floor and sidewalls up to the elevation of the spillway. The Bentomat ${ }^{\circledR}$ liner consists of granulated bentonite sandwiched between two geosynthetic fabrics, and has a manufacturer's estimated permeability of less than $10^{-8}$ centimeters per second $(\mathrm{cm} / \mathrm{sec})$. To protect the Bentomat ${ }^{\oplus}$ liner from erosion and UV exposure, three-to-five-inch thick Kentucky Bluegrass sod was laid on the pond sidewalls, floor, and spillway. An as-built drawing of the pond is included as Plate 1.

As described in Section 3.8 of the Rulison CAP (DOE, 1995a), pond restoration was to include restoring water flow into the pond from the adjacent spring, reintroduction of aquatic vegetation, and restocking with trout. However, at the time the pond restoration activities were implemented, the property owner did not possess surface water rights to the spring to be used to 
fill the pond, so flow from the spring into the pond was not restored. However, subsequent to completion of the cleanup operations, the landowner was granted temporary use of the spring to refill the pond, and as of February 1996 the pond has been filled. Restocking of the pond with trout currently is scheduled for the summer of 1997. 


\subsection{Surface Ground Zero Area Investigation}

The SGZ area soil investigation described in this report consisted of three activities:

- Drill and sample soil borings in the vicinity of the R-EX well to determine if nonradioactive contamination exists in the mud pits adjacent to the well, and to confirm the findings of the extensive radiological surveys conducted during site deactivation and abandonment.

- Collect stream sediment, stream bank soil, and stream water samples from the reach of the stream adjacent to and downgradient of the R-EX well to determine if any contaminants present in the mud pits are migrating to the stream.

- Collect shallow soil samples for radiological analyses from the gas flare and R-EX well areas to confirm the findings of the radiological surveys conducted during site deactivation and abandonment, and to alleviate any public concerns regarding potential exposure to radiation.

All sample collection activities were performed in accordance with DOE-approved, IT Standard Operating Procedures. Sample handling, transport, and analyses were performed in accordance with the Rulison QAPP (DOE, 1995d).

\subsection{Soil Borings}

A total of eight soil borings were drilled in the R-EX well mud pit area (Figure 4-1). Soil borings SB01 through SB05 were drilled to a depth where native soils were encountered, which was considered to represent the bottom of the mud pits and was thought to be uncontaminated. Soil boring SB06 originally was intended to be drilled to a depth where native soils were encountered. However, when relatively high photoionization detector (PID) readings were obtained from sampling intervals in SB06, it was decided in the field to continue drilling to the water table to assess whether the apparent contamination had migrated to the groundwater. In addition, it was decided in the field to drill two additional soil borings (SB07 and SB08) to the water table in the vicinity of SB06 to assess the potential horizontal and vertical extent of the apparent contamination encountered in SB06.

\subsubsection{Soil Boring Drilling and Sampling}

The soil borings were drilled with an Ingersoll Rand TH 60 drill rig using air rotary drilling techniques with a 4.5 -in. bit or a 5-in. Odex ${ }^{\circledR}$ hammer. Soil samples were collected from the 


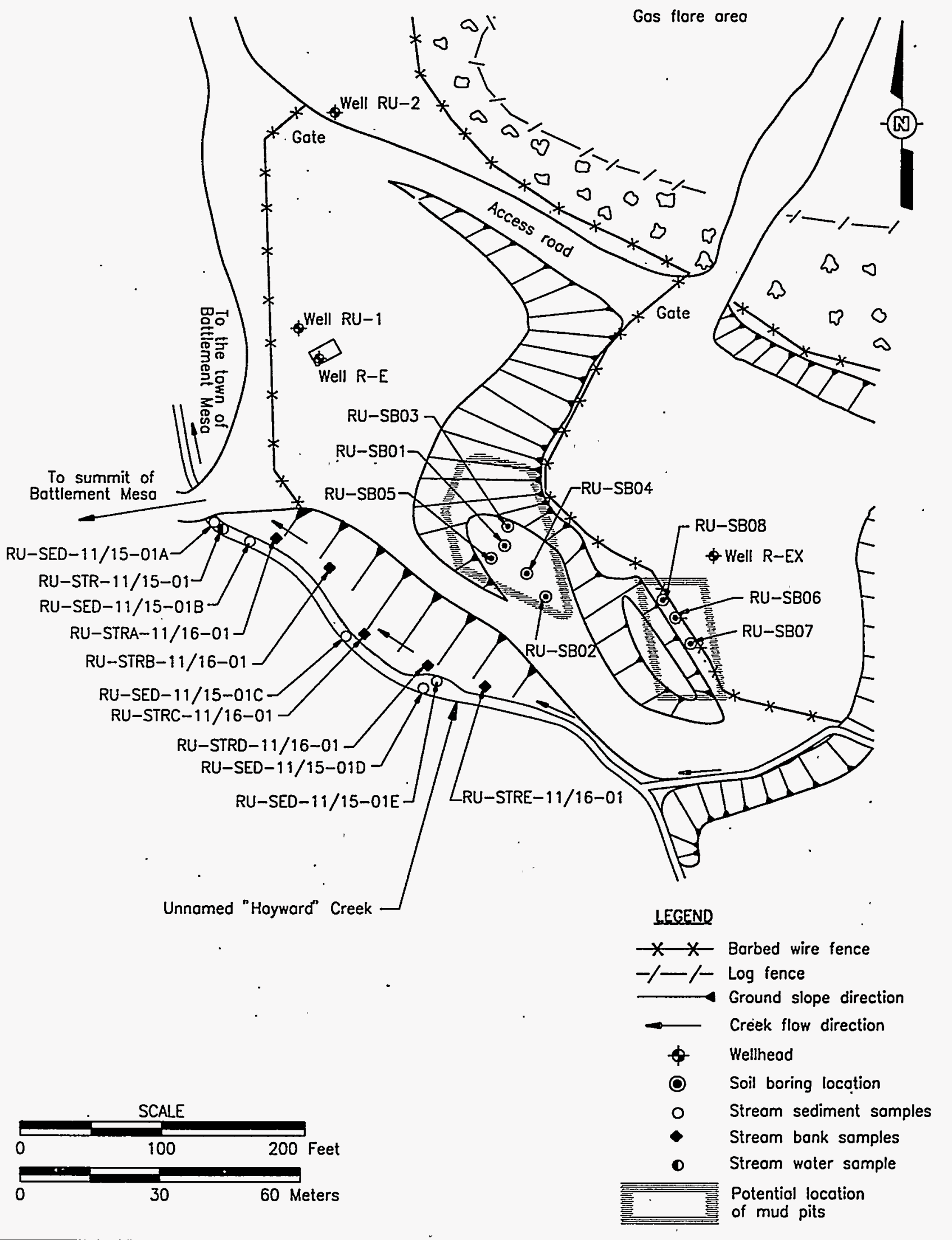

Figure 4-1

Surface Ground Zero Area Soil Boring and Stream Sample Locations 
borings using 2-in. and 3-in. diameter stainless steel split-spoon sample barrels. The split-spoon sample barrels were driven into the soil with a 140-pound hammer or pushed into the soil by the drill rig. The first soil boring drilled was soil boring SB03. The soil samples from this boring were collected with a 2-in. diameter, 18-in. long stainless steel split spoon lined with three 6-in. long brass sleeves. However, the recovery from the sample barrel was not adequate to provide enough soil for the entire analytical suite. In order to improve recovery, the remaining seven borings were sampled using 3-in. diameter, 18-in. long stainless steel split spoon sample barrels. Brass sleeve inserts were not available for the three-inch split spoon sample barrels.

Soil samples were collected at five-foot intervals in each boring. An aliquot of soil from each sample was placed in a clean plastic bag for head-space analysis using a field-portable PID. Two samples from each boring were submitted to the laboratory for chemical analysis: a sample from the interval that showed the highest head-space PID reading, and a sample from the bottom of the soil boring. Pending results of the head-space analysis comparison, sample aliquots for benzene, toluene, ethylbenzene, and xylenes (BTEX) analyses were stored in the appropriate volatile sample bottles, and the remaining soil, collected for non-volatile analyses, was placed temporarily in decontaminated Mason $^{\circledR}$-type glass jars or clean plastic bags until the sample interval with the highest headspace reading was identified. All soil sample containers were immediately stored on ice in coolers until the sample interval with the highest PID reading was identified. The soil stored for non-volatile analyses from this interval was then placed into sample containers for shipment to the laboratory. In the cases where there was not enough soil available from the interval to provide the required volume for the specified non-volatile analyses, soil from the interval with the next highest head space reading was thoroughly mixed with the soil from the highest PID reading interval to provide the necessary soil sample volume. Soil boring logs are included in Appendix $F$ of this report.

\subsubsection{Soil Boring Abandonment}

The soil borings were abandoned by backfilling them with a grout mixture of Portland cement with 5 percent bentonite to within two feet of the surface. The remaining two feet were then backfilled to the ground surface with native soil. Soil borings that penetrated the water table were backfilled with $\# 20$ Colorado Silica Sand from the bottom of the boring to above the water table before the grout was added. In two of the borings, RU-SB05 and RU-SB06, material had sloughed in to approximately eight feet below surface. Grout was placed on top of the sloughed material to within two feet of the ground surface, followed by native soil backfill to the ground surface. 


\subsubsection{Soil Boring Analytical Results}

The soil boring samples were analyzed for BTEX, TPH, Resource Conservation and Recovery Action (RCRA) metals (both total and TCLP-extractable), gross alpha/gross beta, and tritium. The shallow sample from each boring also was analyzed using gamma spectroscopy. The analytical results for the soil boring samples are presented in Table 4-1. The depth interval from which each sample was collected is reflected in the sample numbering system, where the third number or set of numbers in the sample code is the depth or depths (in feet) from which the soil sample was collected. For example, the third set of numbers for sample number RU-B03-5/10/15 indicates that the sample was a composite consisting of soil collected from the 5-, 10- and 15-foot depth intervals.

TPH was detected in the shallow samples from all eight soil borings, and in deep samples from four of the eight borings. Detected concentrations in the shallow samples ranged from $66 \mathrm{mg} / \mathrm{kg}$ in sample SB03-05/10/15 to $4,700 \mathrm{mg} / \mathrm{kg}$ in SB07-18/22-1. Detected concentrations in the deep samples ranged from $66 \mathrm{mg} / \mathrm{kg}$ in SB01-15 to $150 \mathrm{mg} / \mathrm{kg}$ in SB-02-20.

BTEX compounds were detected in shallow samples from four of the eight soil borings. With the exception of ethylbenzene and xylene concentrations in sample SB08-05/10 $(1,400$ micrograms per kilogram $[\mu \mathrm{g} / \mathrm{kg}]$ and $23,000 \mu \mathrm{g} / \mathrm{kg}$, respectively), all detected concentrations for the BTEX compounds were below $1,000 \mu \mathrm{g} / \mathrm{kg}$. Ethylbenzene and/or xylenes also were detected in deep samples from three of the eight soil borings. All detected concentrations in the deep samples were below $1,000 \mu \mathrm{g} / \mathrm{kg}$.

The concentrations of barium, chromium, and lead appeared to be elevated above background in shallow samples from three of the eight soil borings. The maximum detected concentration of these metals were $3,990 \mathrm{mg} / \mathrm{kg}$ barium in SB05-02, $112 \mathrm{mg} / \mathrm{kg}$ chromium in SB06-21/13, and $119 \mathrm{mg} / \mathrm{kg}$ lead in SB07-18/22-1. None of the RCRA metals exceeded RCRA maximum concentration of contaminants (MCC) for the Toxicity Characteristic in the TCLP leachates from the samples.

No nuclear test-derived man-made radionuclides were detected, and all radiological measurements were within natural background levels. 


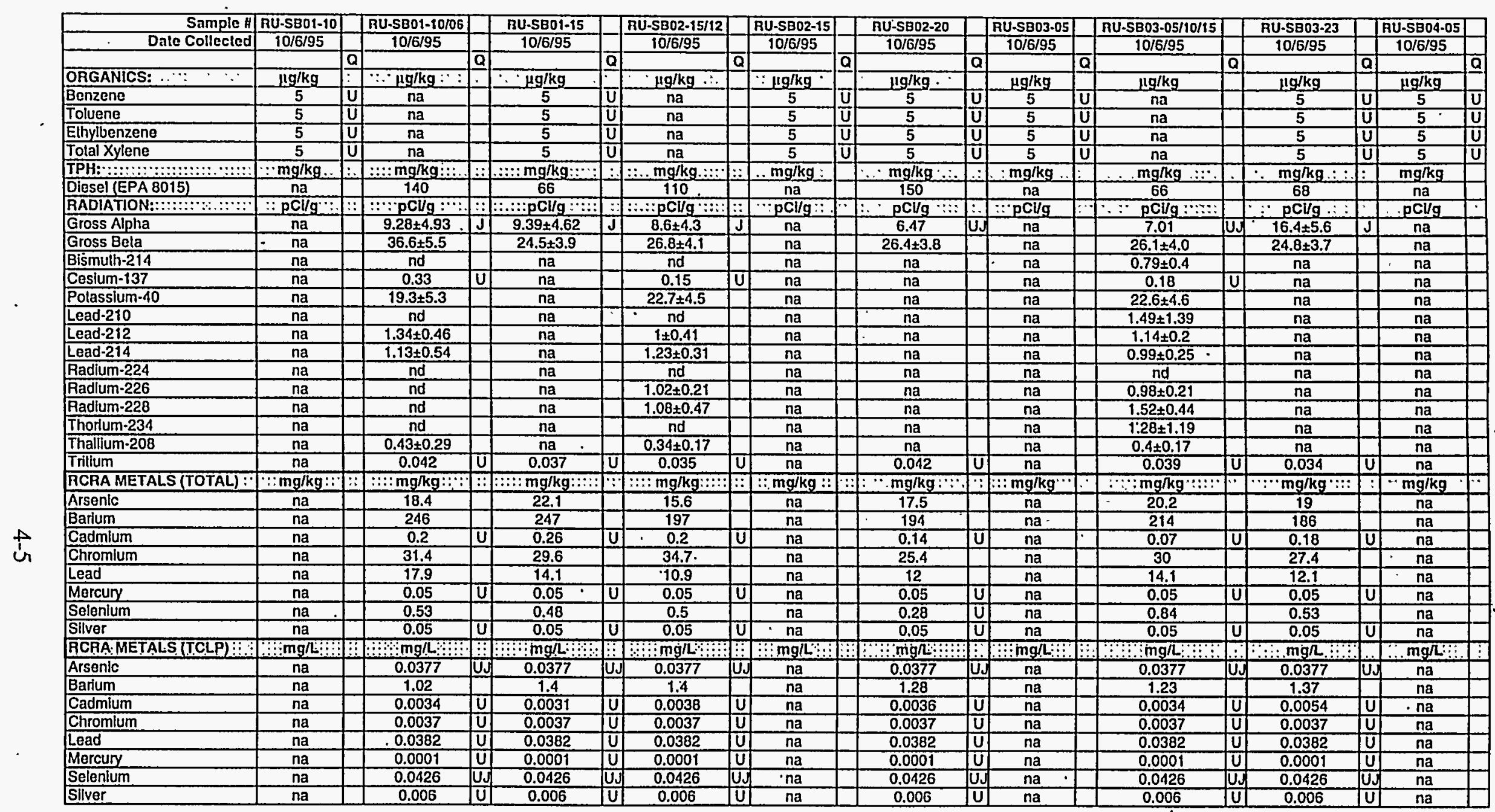

Table 4-1

Surface Ground Zero Area Soil Boring Sample Analytical Results

(Page 1 of 3 ) 


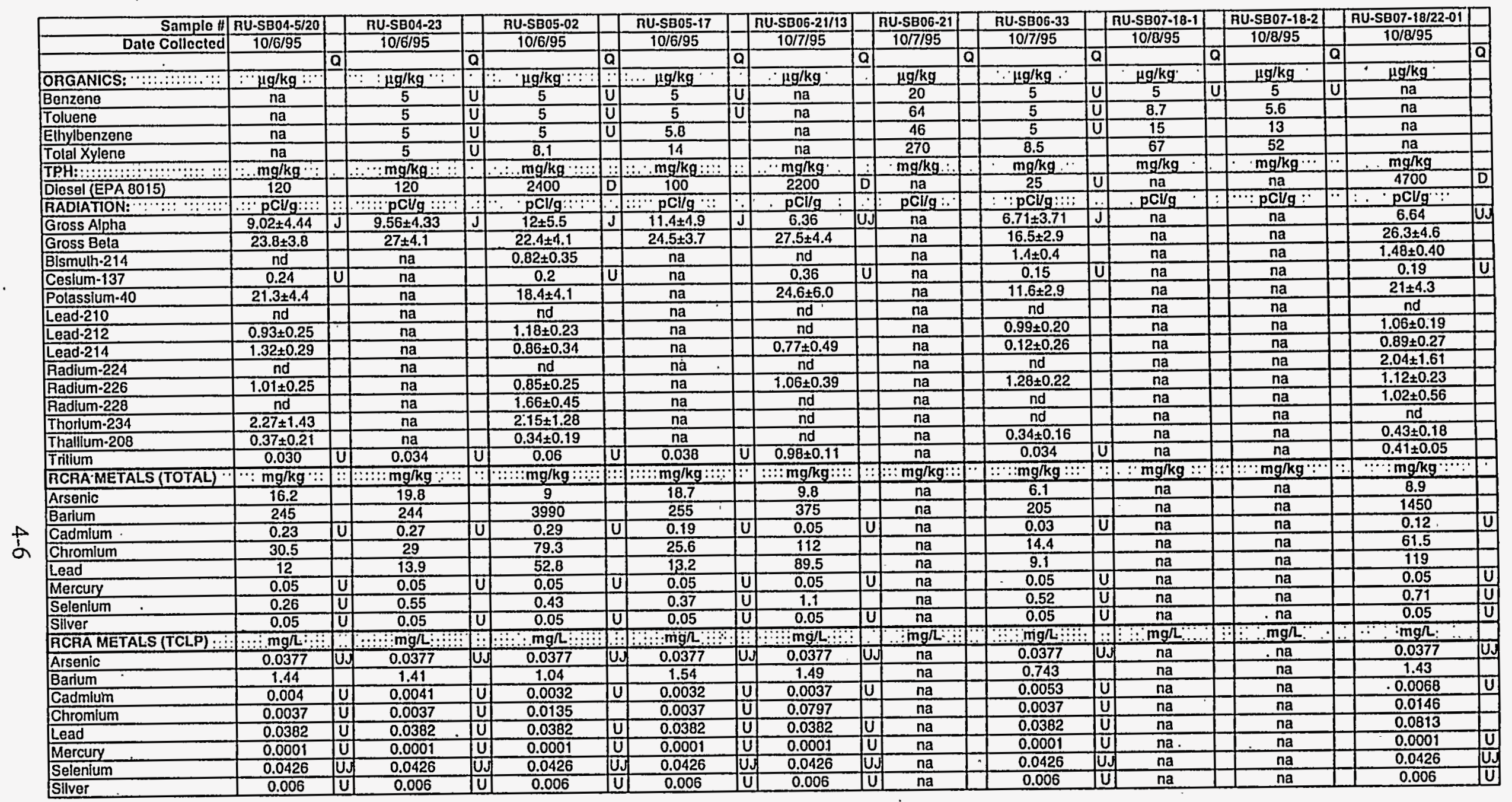

$-\cdots$

Table 4-1

Surface Ground Zero Area Soil Boring Sample Analytical Results

(Page 2 of 3 ) 


\begin{tabular}{|c|c|c|c|c|c|c|c|c|c|c|c|c|}
\hline Sample H & RU-SB07-18/22-02 & & nU.SB07-23 & & RU-SB07-30 & & RU-SBOB-05 & & RU-SBO8-05/10 & & RU-SBOB-31 & \\
\hline Dalo Collected & $10 / 8 / 95$ & & $10 / 8 / 95$ & & $10 / 8195$ & & $10 / 8 / 95$ & & $10 / 8 / 95$ & & $10 / 8 / 95$ & \\
\hline & & Q & & a & & $\bar{a}$ & & Q & & Q & & $\overline{\mathbf{a}}$ \\
\hline ORGANICS: $\cdots \cdot \cdot$ & $\mu \mathrm{g} / \mathrm{kg}$ & & $\mu \mathrm{g} / \mathrm{kg}$ & & $\mu \mathrm{g} / \mathrm{kg}$ & & $\mu g / \mathrm{kg}$ & & $\mu \mathrm{g} / \mathrm{kg}$ & & $\mu \mathrm{g} / \mathrm{kg}$ & \\
\hline Benzene & na & & 5 & $\mathbf{U}$ & 5 & $\bar{U}$ & 290 & & na & & 5 & $\bar{U}$ \\
\hline Toluene & na. & & 27 & & 5 & $\mathrm{U}$ & 120 & U一 & na & & 5 & $\bar{U}$ \\
\hline Elhylbenzene & na & & 41 & & 5 & $\bar{U}$ & 1400 & & na & & 15 & \\
\hline Tolal Xylene & na & & 210 & & 5 & $\underline{\mathbf{u}}$ & 23000 & & na & & 220 & \\
\hline TPH: : & $\therefore \mathrm{mg} / \mathrm{kg} \cdots$ & $\because$ & $\therefore \mathrm{mg} / \mathrm{kg}$ & & $\mathrm{mg} / \mathrm{kg}$ & & $\mathrm{mg} / \mathrm{kg}$ & & $\therefore \mathrm{mg} / \mathrm{kg}$ & & $\mathrm{mg} / \mathrm{kg}=$ & \\
\hline Diesel (EPA B015) & 3500 & $\underline{D}$ & $\mathrm{na}$ & & 24 & $\bar{U}$ & na & & 2100 & D & 24 & $\bar{U}$ \\
\hline AADIATION: ::::::: & $\therefore: \mathrm{pCl} / \mathrm{g}::: \because$ & $\because$ & $\because \mathrm{pCl} / \mathrm{g}:-$ & & $\mathrm{pCl} / \mathrm{g} \cdot$ & & $\mathrm{pCV} / \mathrm{g}:$ & & $\because \mathrm{pcl} / \mathrm{g}:$ & & $\therefore \mathrm{pCl} / \mathrm{g}$ & \\
\hline Gross Alpha & $11.5 \pm 5.4$ & $\mathrm{~J}$ & \begin{tabular}{|l} 
na \\
\end{tabular} & & $9.72 \pm 4.41$ & $\mathbf{J}$ & na & & 7.68 & UU & $10.4 \pm 5.1$ & $\mathrm{~J}$ \\
\hline Gross Bela & $23.3 \pm 4.0$ & & na & & $21.7 \pm 3.5$ & & na & & $29.8 \pm 4.7$ & & $.18 .3 \pm 3.4$ & \\
\hline Bismulh-214 & $1.01 \pm 0.30$ & & na & & na & & na & & $1.33 \pm 0.39$ & & na & \\
\hline Ceslum-137 & 0.21 & U & na & & na & & na & & 0.2 & $\mathrm{U}$ & na & \\
\hline Polasslum- 40 & $16.6 \pm 3.6$ & & na & & na & & na & & $23.1 \pm 4.7$ & & na & \\
\hline Lead-210 & nd & & na & & na & & na & & $2.17 \pm 1.82$ & & $\mathrm{na}$ & \\
\hline Lead-212 & $1.03 \pm 0.26$ & & na & & na & & na & & $1.39 \pm 0.26$ & & na & \\
\hline Lead-214 & $0.79 \pm 0.27$ & & na & & na & & na & & $0.88 \pm 0.32$ & & na & \\
\hline Radlum-224 & $3.6 \pm 2.3$ & & na & & na & & na & & $3.14 \pm 2.53$ & & na & \\
\hline Radlum-226 & $0.9 \pm 0.2$ & & na & & na & & na & & $1.07 \pm 0.25$ & & na & \\
\hline Radium-228 & nd & & na & & na & & na & & $1.55 \pm 0.52$ & & na & \\
\hline Thorium-234 & nd & & na & & na & & na & & nd & & na & \\
\hline Thalllum $\cdot 208$ & $0.37 \pm 0.13$ & & na & & na & & na & & $0.56 \pm 0.27$ & & na & \\
\hline Tritlum & $0.38 \pm 0.05$ & & \begin{tabular}{|l}
$\mathrm{na}$ \\
\end{tabular} & & 0.038 & IU & na & & $0.024 \pm 0.014$ & & $0.062 \pm 0.015$ & \\
\hline RCAA METALS (TOTAL): & $a: i: \mathrm{mg} / \mathrm{kg}: \mathrm{n}: \mathrm{n}$ & :a: & :mg/kg: & $\therefore:$ & $\because: \cdot \mathrm{mg} / \mathrm{kg}::::$ & $\therefore$ & $\because \mathrm{mg} / \mathrm{kg}$ & 9 & $\mathrm{in:mg/kg} \mathrm{::}$ & $\because$ & $\therefore \mathrm{mg} / \mathrm{kg}: \mathrm{:}$ & $\because$ \\
\hline Arsenic & 7.5 & & $\because \mathrm{na}$ & & 11.7 & & na & & 13.4 & & 5.9 & \\
\hline Barium & 670 & & na & & 339 & & na & & 298 & & 113 & \\
\hline Cadmium & 0.37 & & na & & 0.03 & $\bar{u}$ & na & & 0.03 & U & 0.03 & U \\
\hline Chromium & 44 & & $\mathrm{na}$ & & 17.8 & & na. & & 35.1 & & 13.2 & \\
\hline Lead & 89 & & na & & 12 & & na & & 17.5 & & 6.7 & \\
\hline Mercury & 0.05 & $\mathrm{U}$ & na & & 0.05 & 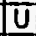 & na & & 0.05 & U & 0.05 & $\mathrm{U}$ \\
\hline Selenlum & 0.52 & U & na & & 0.98 & $\bar{U}$ & na & & 0.53 & $\bar{U}$ & 0.47 & U \\
\hline Silver & 0.05 & U & na & & 0.05 & $\bar{U}$ & na & & 0.05 & U & 0.05 & U \\
\hline RGAA METALS (TCLP)S & intinght: & : & :ing/l:: & & :ing/l & $\vdots$ & inghi: & & $\mathrm{mg} / \mathrm{hi}$ & & $\mathrm{mg} / \mathrm{t}$ & $\therefore$ \\
\hline Arsenic & 0.0377 & $\underline{\mathbf{U U}_{\mathbf{U}}}$ & na & & 0.0377 & Uu & na & & 0.0377 & Uu & 0.0377 & Uि \\
\hline Barium & 1.51 & & na & & 0.889 & & na & & 1.75 & & 0.757 & \\
\hline Cadmlum & 0.0056 & U & na & & 0.0049 & $\bar{U}$ & na & & 0.0035 & $\bar{U}$ & 0.0046 & $\bar{U}$ \\
\hline Chromium & 0.0155 & & na & & 0.0037 & $\bar{U}$ & na & & 0.0037 & U & 0.0037 & U \\
\hline Lead & 0.056 & & na & & 0.0382 & U & na & & 0.0382 & U & 0.0382 & U \\
\hline Mercuny & 0.0001 & U & na & & 0.0001 & $\mathrm{U}$ & na & & 0.0001 & U & 0.0001 & $\bar{U}$ \\
\hline Selenlum & 0.0426 & $\mathrm{Uu}$ & na & & 0.0426 & UJ & na & & 0.0426 & Uu & 0.0426 & US \\
\hline Silver & 0.006 & $U$ & na & & 0.006 & U & na & & 0.006 & (0) & 0.006 & $\bar{u}$ \\
\hline
\end{tabular}

$\mathrm{Q}=$ Data qualifier

$\mathrm{U}=$ Compound was analyzed for, bul nol detecled above the specilled limil

$\mathrm{J}=$ Reported value is estimated

$D=$ Sample was diluted for analys $\mid s$

$\mathrm{mg} / \mathrm{kg}=$ milligrams per kllogram

$\mu \mathrm{g} / \mathrm{kg}=$ mlcrograms per kllogram .

$\mathrm{mg} / \mathrm{L}=$ milligrams per liter

$\mathrm{pCl} / \mathrm{g}=$ picoCuries per gram

$\mathrm{na}=$ not analyzed

nd $=$ nol delected

Table 4-1

Surface Ground Zero Area Soil Boring Sample Analytical Results

(Page 3 of 3 ) 


\subsection{Stream Investigation}

One composite stream sediment sample, one composite stream bank soil sample, and one discrete stream water sample were collected to assess whether contaminants from the R-EX mud pit area are migrating to the stream. The stream sediment sample and the stream bank soil sample each consisted of a composite sample made up of material collected from five separate sampling locations (sediment sampling locations RU-SED-11/15-01A through -01E and stream bank soil sampling locations RU-STRA-11/16-01 through -STRE-11/16-01 on Figure 4-1).

The stream bank soil samples were collected by using a shovel to remove the soil to the frost line at each of the five sample locations. Soil samples were collected at each location with decontaminated polyethylene scoops. The soil collected from the five sample locations was placed in a stainless steel bowl, thoroughly homogenized into one composite sample, and then placed in sample containers for shipment to the laboratory.

Stream sediment samples were collected with a polyethylene plastic scoop. Two scoops of sediment were collected from each sampling location, beginning with the downstream sample location (RU-SED-11/15-01A) and working upstream in an easterly direction. The sediment collected from the five sample locations was placed in a stainless steel bowl, thoroughly homogenized into one composite sample, and then placed in sample containers for shipment to the laboratory.

The stream water sample was collected by using a polyethylene scoop to collect the stream water and pour it directly into the sample containers for shipment to the laboratory.

\subsubsection{Stream Analytical Results}

The stream sediment, stream bank soil, and stream water samples were analyzed for TPH and total RCRA metals. The analytical results for the samples are presented in Table 4-2. In Table 4-2, the stream sediment composite sample is numbered RU-SED-11/15-01; the stream bank soil composite sample is numbered RU-STRB-11/16-01; and the stream water sample is numbered RU-STR-11/15-01. TPH was not detected in any of the stream samples, and metals concentrations do not appear to be elevated, which suggests that contamination has not migrated via saturated and unsaturated transport to the stream from the R-EX mud pits. Hayward Creek, a local groundwater discharge zone, is upgradient, cross-gradient, and downgradient from the R-EX mud pits. 
Table 4-2

Surface Ground Zero Area Stream Sample Analytical Results

\begin{tabular}{|c|c|c|c|c|c|c|}
\hline Sample \# & RU-SED-11/15-01 & & RU-STR-11/15-01 & & RU-STRB-11/16-01 & \\
\hline Date Collected & $11 / 15 / 95$ & & $11 / 15 / 95$ & & $11 / 16 / 95$ & \\
\hline Sample Location & Stream Bed & & Stream water & & Stream Bank & \\
\hline & & $\mathbf{Q}$ & & $\mathbf{Q}$ & & $\mathbf{Q}$ \\
\hline TPH (Method 8015) & mg/kg & $\therefore$ & mg/L & $\because$ & $\therefore \mathbf{m g} / \mathbf{k g}$ & \\
\hline Diesel & 25 & $\mathrm{U}$ & 0.5 & $\mathrm{U}$ & 24 & $\mathrm{U}$ \\
\hline Waste Oil & 25 & $U$ & $0: 5$ & $U$ & 24 & U \\
\hline Total RCRA Metals. & $\mathrm{mg} / \mathrm{kg}$ & . & $" \therefore$, ug/L & $\because$ & $\because \ldots \cdots \mathbf{m g} / \mathbf{k g}$ & \\
\hline Arsenic & 15.7 & & 3.9 & $B$ & 13.9 & \\
\hline Barium & 164 & & 43.6 & $B$ & 217 & \\
\hline Cadmium & 0.33 & $\mathrm{~B}$ & 2.3 & $U$ & 0.44 & $B$ \\
\hline Chromium & 22.4 & & 3.7 & $U$ & 27.8 & \\
\hline Lead & 10.5 & & 0.80 & $U$ & 12.5 & \\
\hline Selenium & 0.26 & $\mathrm{U}$ & 2.6 & $U$ & 0.26 & $\mathrm{U}$ \\
\hline Silver & 0.60 & $\mathrm{U}$ & 6.0 & $\mathrm{U}$ & 0.60 & $U$ \\
\hline Mercury & 0.05 & $U$ & 0.10 & $\mathrm{U}$ & 0.05 & $U$ \\
\hline
\end{tabular}

Notes:

$Q=$ Laboràtory assigned data qualifier

$U=$ Compound was analyzed but not detected above the specified limit.

$B=$ Result is above the Instrument Detection Limit but below the Contract Required Detection Limit.

$\mathrm{mg} / \mathrm{L}=$ milligrams per liter; ug $\mathrm{L}=$ micrograms per liter; $\mathrm{mg} / \mathrm{kg}=$ milligrams per kilogram

\subsection{Radiological Investigation}

A total of nine locations were sampled for the radiological investigation: one in the vicinity of the R-EX well and eight downwind of the flare stack area (Figure 4-2). Sample holes for the radiological soil samples were excavated by hand with shovels, a post-hole digger, and a pry bar. Soil was removed to expose the interface between the $E$ and B soil horizons (USDA, 1992). This depth ranged between approximately 0.6 and $2 \mathrm{~m}$ ( 2 and $4 \mathrm{ft}$ ) below the ground surface. This interface represents the depth at which the organic mineral soil horizon transitions into the soil horizon dominated by alterations that form silicate clays of granular, blocky, or prismatic structure. This transition also represents a zone of contact between two contrasting soil textures resulting in a capillary barrier. Percolating water tends to pond at this interface; therefore, if tritium was present, this would be the most logical place to sample. In addition, since radionuclides readily adsorb to clay particles, this interface was considered to be the most likely depth to find radiological contamination, if any existed. At each sampling location, equal amounts of soil were collected from above and below, but not at, the interface with a precleaned 


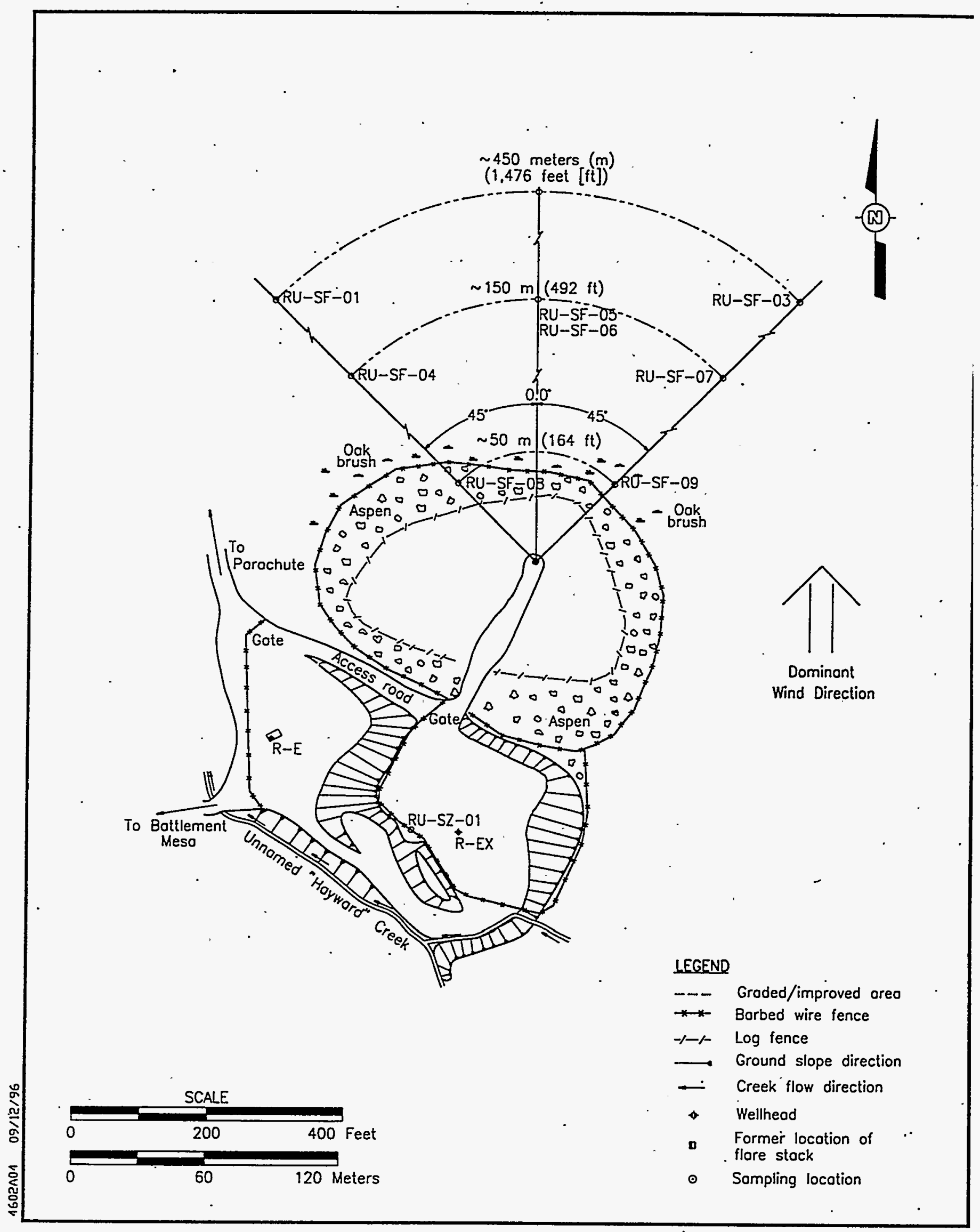

Figure 4-2
Radiological Sampling Locations

4-10. 
polyethylene scoop or a stainless steel spoon and placed in a stainless steel bowl. The soil was thoroughly homogenized in the bowl and then transferred to analytical sample containers for shipment to the laboratory. After the sample was collected from each excavation, the excavation was backfilled with native soil.

\subsubsection{Radiological Analytical Results}

The radiological investigation soil samples were analyzed for gross alpha/gross beta, tritium, carbon-14, and by gamma spectroscopy. The analytical results for the samples are presented in Table 4-3. All radionuclides detected in the samples using gamma spectroscopy are naturally occurring, and detected concentrations were not elevated above natural background levels. 


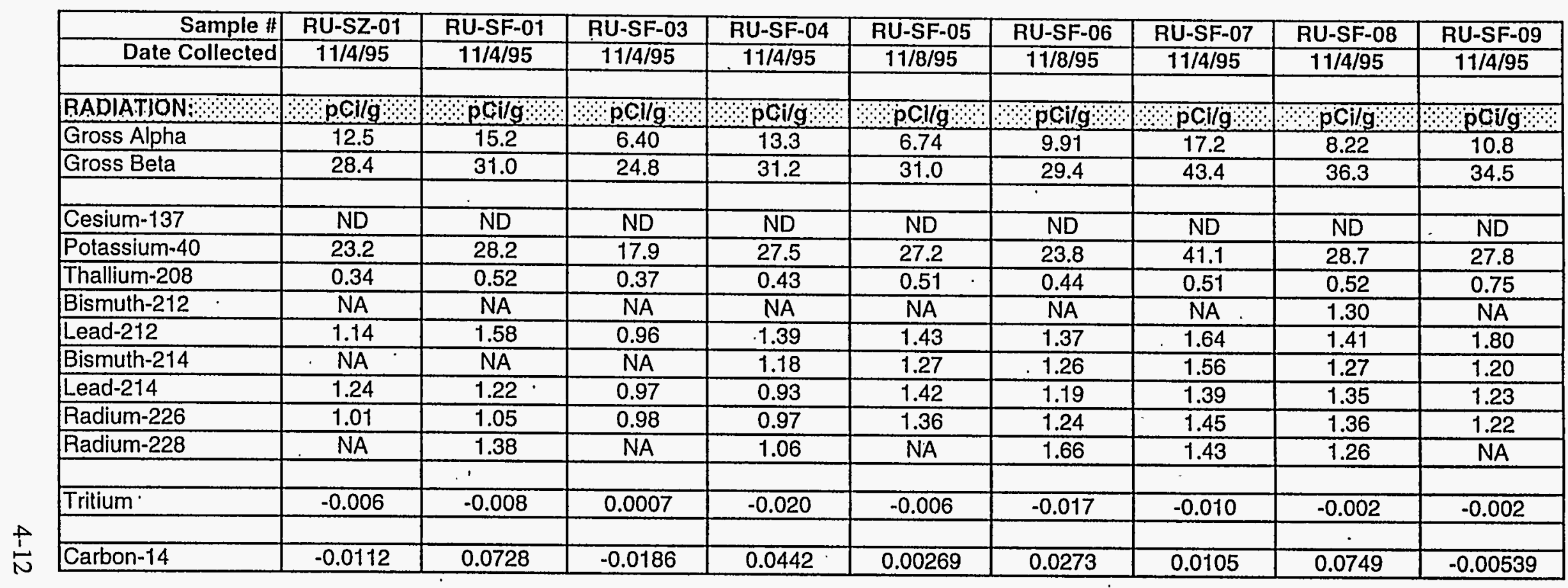

Notes:

$N A=$ Sample not analyzed for indicated compound.

$N D=$ Analyte not detected above method detection limit.

$\mathrm{pCl} / \mathrm{g}=$ picoCuries per gram

Table 4-3

Surface Ground Zero Area Radiological Sample Analytical Results 


\subsection{Monitoring Well Installation and Sampling}

A total of seven groundwater monitoring wells were installed at the site as part of the pond cleanup operation and SGZ area investigation. The monitoring well locations are shown on Figure 5-1. Two of these wells, RU-01 and RU-02, were installed hydraulically downgradient of well R-E to monitor for potential contaminant migration from the SGZ area. Monitoring well RU-03 was installed upgradient from the drilling effluent pond and monitoring wells RU-05, RU-06A, RU-07, and RU-08 were installed downgradient from the pond to monitor for potential contaminant migration from the pond.

Monitoring wells RU-01 through RU-03 and monitoring well RU-6A were installed using air rotary drilling techniques. Monitoring wells RU-05, RU-07, and RU-08 were installed in handdug excavations. Well RU-06 was originally hand-dug; however; it was determined in the field that a deeper monitoring well downgradient of the pond was desirable to allow aquifer testing to be conducted, and the best place to install a deeper well was in the vicinity of RU-06. As a result, RU-06 was abandoned, and monitoring well RU-06A was installed in its place. Monitoring Well RU-04, proposed in the Rulison CAP (DOE, 1995a) as an upgradient well for the pond, was primarily intended to be used to obtain aquifer data to support design and installation of construction dewatering wells. Since construction dewatering was accomplished by using an interceptor trench (see Section 3.1) rather than wells, it was decided in the field that installation of RU-04 was not necessary, as monitoring well RU-03 would provide adequate upgradient background water quality information for groundwater monitoring purposes.

Monitoring well development and the handling of drilling cuttings, decontamination fluids, and water generated during well development were conducted in accordance with the Rulison CAP (DOE, 1995a). Soil boring logs and monitoring well completion diagrams for the wells are included in Appendix G.

\subsection{Groundwater Analytical Results}

One round of groundwater samples was collected during the pond cleanup operation and SGZ area investigation. This round of samples was collected after all monitoring wells had been installed and developed. Monitoring wells RU-05 and RU-07 were dry during the sampling event. Analytical results for the sampling round are presented in Table 5-1. The analytical results indicate that all of the targeted analytes were below their respective maximum contaminant levels. In addition, with the exception of barium which may be of local natural origin, none of the potential contaminants identified in the SGZ area soil boring samples were 


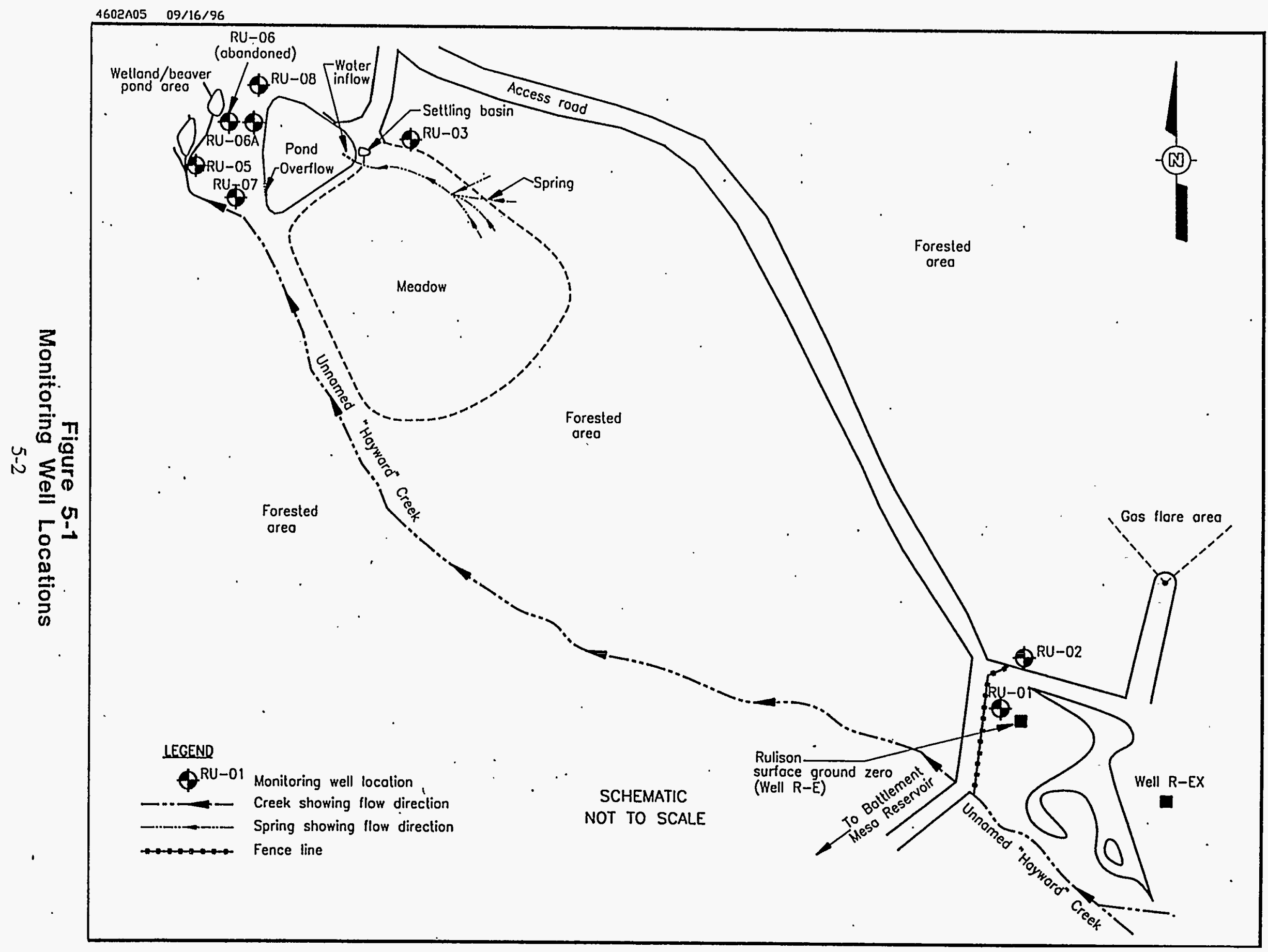


Table 5-1

Groundwater Analytical Results, October 1995 Samples

\begin{tabular}{|c|c|c|c|c|c|c|c|c|c|c|}
\hline Well & RU-01 & & RU-02 & & RU-03 & & RU-06A & & RU-08 & \\
\hline & Conc. & $Q$ & Conc. & $\mathbf{Q}$ & Conc. & $\mathbf{Q}$ & Conc. & $\mathbf{Q}$ & Conc. & $\mathbf{Q}$ \\
\hline METALS: & $\mathrm{ig} / \mathrm{l}$ & $\Leftrightarrow$ & $\Leftrightarrow \mu$ ind & $\because$ & $\because \mu \mathrm{\mu} / \mathrm{L}$ & $\because$ & $\mu \mathrm{g} / \mathrm{L}$ & & $\because \mu \mathrm{i}$ & \\
\hline Arsenic & 3.1 & $U$ & 5.3 & $B$ & 3.1 & $U$ & 3.1 & $\mathrm{U}$ & 4.4 & $\mathrm{~B}$ \\
\hline Barium & 68.2 & & 77.2 & $\mathrm{~B}$ & 85.9 & & 134 & & 258 & \\
\hline Cadmium & 0.3 & $\mathrm{U}$ & 5 & $U$ & 0.3 & $U$ & 0.3 & $U$ & .5 & $U$ \\
\hline Calcium & na & & 66200 & & 64200 & & 77300 & & 73600 & \\
\hline Chromium & 2.7 & $\mathrm{U}$ & 20 & $\mathrm{U}$ & 2.7 & $U$ & 2.7 & $\mathrm{U}$ & 20 & $\bar{U}$ \\
\hline Iron & na & & 2390 & & 1410 & $\mathrm{~J}$ & 1140 & $\mathrm{~J}$ & 1820 & \\
\hline Lead & 1.8 & $\mathrm{U}$ & 3 & $\mathrm{U}$ & 1.7 & $U$ & 0.8 & $\mathrm{U}$ & 5.1 & \\
\hline Magnesium & na & & 31800 & & 28500. & & 31600 & & 28800 & \\
\hline Mercun & 0.13 & $U$ & 0.13 & $B$ & 0.13 & $U$ & 0.12 & $\mathrm{U}$ & 0.14 & $\bar{B}$ \\
\hline Potassium & na & & 5000 & $\mathrm{U}$ & 1390 & $\bar{U}$ & 2670 & & 2490 & $B$ \\
\hline Selenium & 4.9 & & 5 & $U$ & 7.2 & $U$ & 5.1 & $\mathrm{U}$ & 4.5 & $\mathrm{~B}$ \\
\hline Silver & 0.5 & $\mathrm{U}$ & 10 & $U$ & 0.5 & $U$ & 0.5 & $\mathrm{U}$ & 10. & $\bar{U}$ \\
\hline Sodium & na & & 52800 & & 51400 & & 39300 & & 36100 & \\
\hline ANIONS & mg/L $/$ & $\because$ & mg/l & $\because$ & ang $/ \mathrm{l} \leftrightarrow$ & $\because \because$ & $\mathrm{mg} / \mathrm{L}-\mathrm{l}$ & $\Leftrightarrow$ & $\mathrm{mg} / \mathrm{L}$ & \\
\hline Bromide & na & & 0.25 & $U$ & 0.25 & $\mathrm{U}$ & 0.25 & $\mathrm{U}$ & na & \\
\hline Chloride & na & & 1.88 & & 1.83 & & 4.86 & & na & \\
\hline Fluoride & na & & 0.34 & & 0.48 & & 0.33 & & na & \\
\hline Sulfate & na & & 70.5 & & 61.1 & & 111 & & na & \\
\hline ORGANIC & $\mu g / \mathrm{L}$ & $\cdots$ & 쎤 & $\because$ & $\because \mu g / \mathbb{L} \because$ & $\cdots$ & $\because \cdots \quad \mathrm{Hg} / \mathrm{L}$ & $\because$ & ugfL & \\
\hline Berizene & 1 & $\mathrm{U}$ & 1 & $\mathrm{U}$ & 1 & $U$ & 1 & $\mathrm{U}$ & 1 & $U$ \\
\hline Toluene & 1 & $U$ & 1 & $U$ & 1 & $\mathrm{U}$ & 1 & $\mathrm{U}$ & 1 & $\mathrm{U}$ \\
\hline Ethylbenzene & 1 & $U$ & 1 & $U$ & 1 & $U$ & 1 & $\mathrm{U}$ & 1 & $\mathrm{U}$ \\
\hline Toial Xylenes & 1 & $U$ & 1.5 & & 1 & U & 1 & $U$ & 1 & $\bar{U}$ \\
\hline TPH: & $\mathrm{mg} / \mathrm{L}$ & $\because$ & mg/: : & $\because$ & $\because \mathrm{mg} / \mathrm{ll}$ & $\because$ & mgll: & $\therefore$ & $\because \because$ mg & \\
\hline Diesel (EPA 8015) & 0.5 & UJ & 0.5 & $U$ & 0.5 & UJ & 0.5 & UJ & 0.5 & $\mathrm{U}$ \\
\hline Motor Oil (EPA 8015) & 0.5 & UJ & 0.5 & $\mathrm{U}$ & 0.5 & UJ & 0.5 & UJ & 0.5 & $\mathrm{U}$ \\
\hline INORGANICS: & $\mathrm{mg} / \mathrm{L}$ & $\because$ & mgll: & $\therefore$ & $\because \mathrm{mg} / \mathrm{L}$ & $\cdots$ & mg/L & & $\because \because \mathrm{mg} / \mathrm{L}$ & \\
\hline Toial Dissolved Solids & na & & 435 & & 406 & & 466 & & 431 & \\
\hline Toia. Suspended Solids & na & & 13 & & 19 & & 46 & & 626 & \\
\hline $\mathrm{DH}$ & na & & 7.5 & & 7.35 & $\mathrm{~J}$ & 7.13 & $J$ & 7.17 & \\
\hline Alk:alıniti & na & & 321 & & 326 & & 278 & & na & \\
\hline BADIATION: & pCi/L & $\because$ & pCifl & $\because$ & $\because$ pCill $\because \because$ & 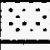 & QpCi/L $\because$ & & $\because \mathrm{pCi} / \mathrm{L}$ & \\
\hline Gross Alohá & 7.31 & $\mathrm{U}$ & 4.78 & & na & & na & & na & \\
\hline Gross Beia & 5.46 & $\mathrm{U}$ & 0.77 & & na & & na & & na & \\
\hline Cesıum-137 & 10 & $U$ & ND & & na & & na & & na & \\
\hline Radium-226 & $0.65 \pm 0.32$ & & -0.1 & & na & & na & & na & \\
\hline Strontiumi-89 & 1.04 & Ud & 0.78 & & na & & na & & na & \\
\hline Strontium-90 & $0.94 \pm 0.47$ & & 0.09 & & na & & na & & na & \\
\hline Tritium & 254 & $U$ & -93 & & na & & na & & na & \\
\hline
\end{tabular}

$Q=$ Data qualifier:

$\mathrm{U}=$ Compound was analyzed but not detected above the specified limit:

$\mathrm{J}=$ Reponed value is estimated.

$\mathrm{B}=$ The result $>\mathrm{IDL}$ but $<\mathrm{CRDL}$.

$\mathrm{mg} / \mathrm{L}=$ milligrams per liter:

$\mu \mathrm{g} L=$ micrograms per liter:

$\mathrm{pCi}=$ picocuries per liter

$\mathrm{ND}=$ parameter was analyzed for but not detected.

$\mathrm{na}=$ not analyzed 
detected in the groundwater samples. This suggests that if the groundwater gradient is toward the northwest, contaminants have not migrated from the R-EX mud pits into the groundwater. The monitoring wells at the site will continue to be monitored as specified in the Rulison LTGMP (DOE, 1995c).

\subsection{Aquifer Testing}

Slug tests were conducted on monitoring wells RU-03 and RU-06A, and a pumping test was conducted on monitoring well RU-02 to provide data on aquifer characteristics. The computer model Aquifer Test Solver software program (AQTESOLV) was used to calculate aquifer hydraulic conductivities based on the slug test and pump test data. Results from the modeling indicate that the hydraulic conductivity of the aquifer in the vicinity of the pond ranges from $2 \times 10^{-3}$ to $4 \times 10^{-4} \mathrm{~cm} / \mathrm{sec}$, and the hydraulic conductivity of the aquifer in the vicinity of surfaceground-zero ranges from $4 \times 10^{-3} \mathrm{~cm} / \mathrm{sec}$ to $5 \times 10^{-3} \mathrm{~cm} / \mathrm{sec}$. The slug test and pump test data and modeling results are included in Appendix $\mathrm{H}$. 


\subsection{Summary and Conclusions}

\subsection{Drilling Effluent Pond}

The cleanup goals as modified herein for the drilling effluent pond sediment have been met. Approximately 14,025,000 liters (3,705,000 gallons) of water were pumped from the pond prior to and during the sediment stabilization and removal operation, and approximately $18,656 \mathrm{~m}^{3}$ $\left(24,400 \mathrm{yd}^{3}\right)$ of stabilized sediment was hauled to the landfill for disposal. Following completion of the sediment stabilization and removal operation, a Bentomat ${ }^{\circledR}$ geosynthetic clay liner was installed in the pond and covered with Kentucky Bluegrass sod to protect it from UV exposure and erosion. At the end of the operation the pond was left unfilled.

As discussed in Section 3.2.1 and documented in the correspondence from the CDPHE included in Appendix E, the CDPHE representative overseeing the drilling effluent pond cleanup work authorized an increase of the TPH cleanup criterion from $250 \mathrm{mg} / \mathrm{kg}$ to $1,000 \mathrm{mg} / \mathrm{kg}$. In conjunction with the higher TPH cleanup criterion, the CDPHE representative requested an estimate of the approximate areas and volumes of sediment with TPH concentrations greater than $250 \mathrm{mg} / \mathrm{kg}$ being left in place. The following assumptions were used to make the requested estimate:

- At each sample location where the final TPH concentration was greater than $250 \mathrm{mg} / \mathrm{kg}$, the TPH contamination extends one-half of the way to the closest adjacent sample locations with TPH concentrations less than or equal to $250 \mathrm{mg} / \mathrm{kg}$.' The areas resulting from this assumption are shown on Figure 6-1.

- Within each area where TPH concentrations are greater than $250 \mathrm{mg} / \mathrm{kg}$, the TPH contamination extends to a depth of 2 feet.

Based on these assumptions, it is estimated that approximately $520 \mathrm{~m}^{3}\left(620 \mathrm{yd}^{3}\right)$ of sediment remaining in the pond contain concentrations of TPH greater than $250 \mathrm{mg} / \mathrm{kg}$, but less than or equal to $1,000 \mathrm{mg} / \mathrm{kg}$. It should be noted that this volume is not continuous, but is spread across ten separate areas in the pond bottom.

\subsection{Surface Ground Zero Area}

Some of the subsurface soil samples collected from the mud pits adjacent to well R-EX contained TPH and elevated levels of barium, chromium, and lead. The analytical data from the mud pit soils have been used to develop a human health risk assessment for the SGZ area soils. The risk assessment is included as Appendix I. Because the subsurface contamination found in 


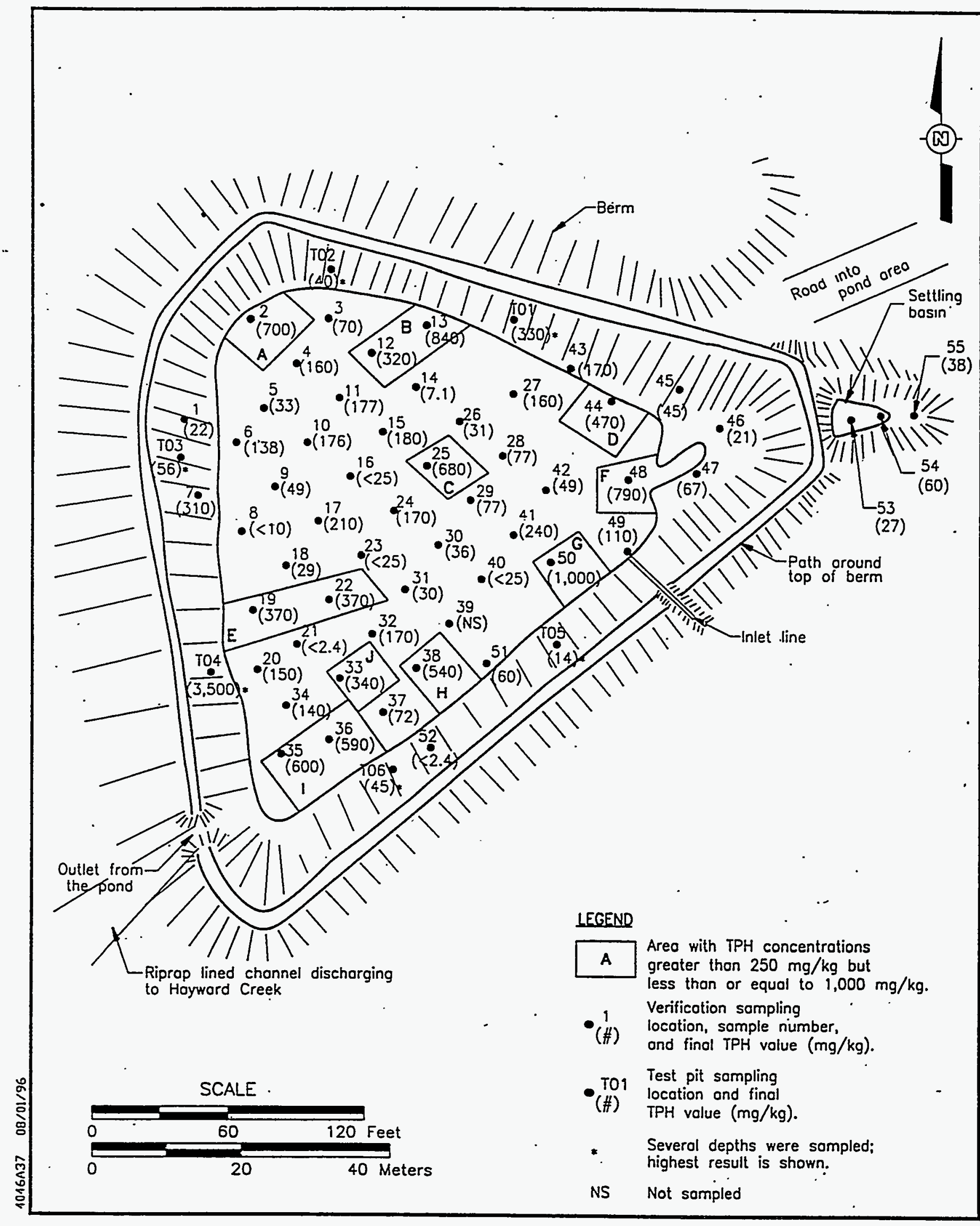

Figure 6-1

Areas of Sediment With TPH Concentrations Between $250 \mathrm{mg} / \mathrm{kg}$ and $1,000 \mathrm{mg} / \mathrm{kg}$ 
the R-EX mud pit subsurface soils would not pose an undue risk to human health even if the soils were excavated and spread on the ground surface, and because there is no evidence that contaminants have migrated from the soils to groundwater or to the adjacent stream, no further action is proposed for the SGZ area soils.

\subsection{Groundwater}

The groundwater sample data for the five monitoring wells sampled in October 1995 have been used to develop a human health risk assessment for the site groundwater (Appendix I). The risk assessment shows that the groundwater currently does not pose an undue risk to human health. The monitoring wells at the site will continue to be monitored as specified in the Rulison LTGMP (DOE, 1995c) and the correspondence from the CDPHE included in Appendix E.

The risk assessment in Appendix I also includes development of groundwater trigger levels for the constituents of potential concern for use during. implementation of the long-term groundwater monitoring program for the site. As described in Appendix I, the trigger levels are risk-based concentrations that, if exceeded, would indicate a need to further evaluate site monitoring data. Trigger levels will be incorporated into the Rulison LTGMP (DOE, 1995c). 



\subsection{Drilling Effluent Pond Closure Certification}

\subsection{U.S. Department of Energy}

I, G. Leah Dever, Environmental Management, U.S. Department of Energy, hereby certify that, to the best of my knowledge and belief, the Rulison Drilling Effluent Pond at the Rulison Site, approximately 8 miles south of Parachute, Garfield County, Colorado, has been restored in accordance with the U.S. Department of Energy, Nevada Operations Office, May 1995, draft Corrective Action Plan and associated documents, including modifications approved by the Colorado Department of Public Health and Environment, and as discussed in the Corrective Action Report.

\section{U.S. DEPARTMENT OF ENERGY}

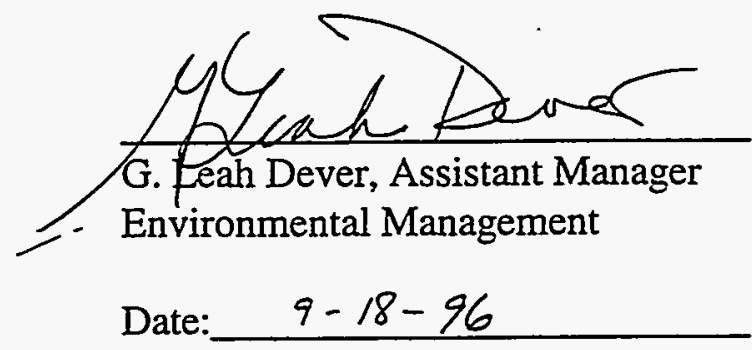

\subsection{Independent Professional Engineer}

I, Lloyd R. Hendry, III, a registered Colorado Professional Engineer, having reviewed the removal action requirements and the resulting documentation, hereby certify that, to the best of my knowledge and belief, the Rulison Drilling Effluent Pond at the Rulison Site, approximately 8 miles south of Parachute, Garfield County, Colorado, has been restored in accordance with the U.S. Department of Energy, Nevada Operations Office, May 1995, draft Corrective Action Plan and associated documents, including modifications approved by the Colorado Department of Public Health and Environment, and as discussed in the Corrective Action Report.
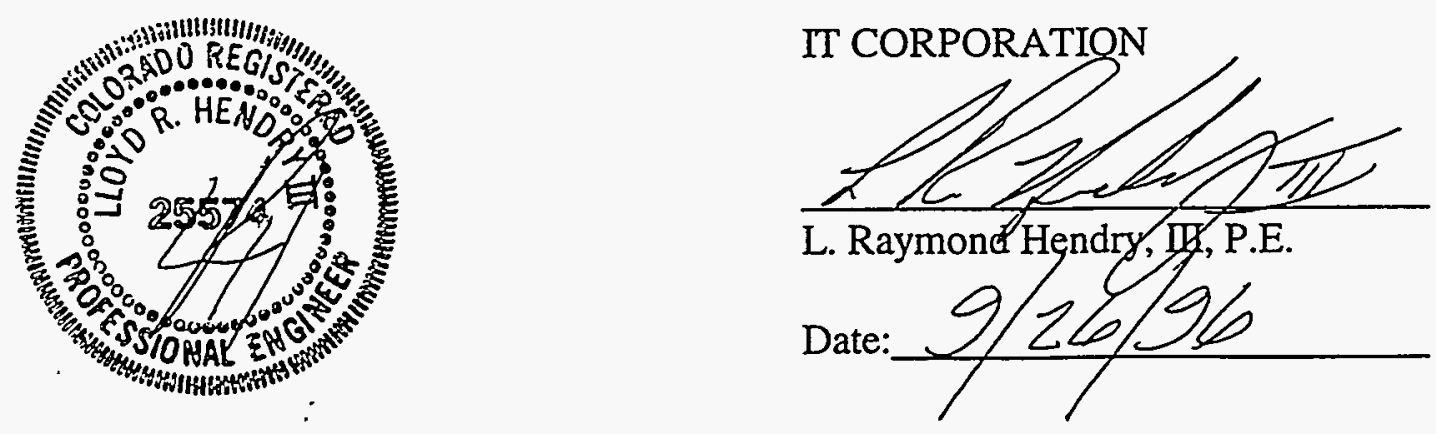



\subsection{References}

AEC, see U.S. Atomic Energy Commission.

DOE, see U.S. Department of Energy.

Eberline, see Eberline Instrument Corporation.

Eberline Instrument Corporation. 1977. Rulison Radiation Contamination Clearance Report. Santa Fe, NM.

ERDA, see U.S. Energy Research and Development Administration.

U.S. Atomic Energy Commission, Nevada Operations Office. 1973. Rulison Site Cleanup Report, NVO-136. Las Vegas, NV.

USDA, see U.S. Department of Agriculture.

U.S. Department of Agriculture, Soil Conservation Service. 1992. Draft, Nationäl Soil Survey Interpretations Handbook. Washington, D.C.

U.S. Department of Energy, Nevada Operations Office. 1995a. Draft, Corrective Action Plan, Rulison Drilling Effluent Pond. Las Vegas, NV.

U.S. Department of Energy. 1995b. Draft, Verification Sampling and Analysis Plan, Rulison Drilling Effluent Pond. Las Vegas, NV: IT Corporation.

U.S. Department of Energy, Nevada Operations Office. 1995c. Final Draft, Rulison Drilling Effluent Pond Site Long-Term Groundwater Monitoring Plan. Las Vegas, NV: IT Corporation.

U.S. Department of Energy, Nevada Operations Office. 1995d. Final Draft Rulison Site Quality Assurance Project Plan. Las Vegas, NV.

U.S. Energy Research and Development Administration, Nevada Operations Office. 1977. Project Rulison Well Plugging and Site Abandonment Final Report, NVO-187.

Las Vegas, NV. 

Appendix A

Variances from the Approved Work Plans 

Table A-1

Corrective Action Plan Variances

(Page 1 of 3 )

\begin{tabular}{|c|c|c|c|c|}
\hline $\begin{array}{l}\text { Variance } \\
\text { Number }\end{array}$ & $\begin{array}{l}\text { Document } \\
\text { Section }\end{array}$ & $\begin{array}{c}\text { Original Technical } \\
\text { Approach }\end{array}$ & Actual Technical Activity & Rationale for Change \\
\hline 1 & $\begin{array}{l}\text { CAP, } 3.2 \\
\text { Para. } 1\end{array}$ & $\begin{array}{l}\text { Use of open area adjacent to } \\
\text { the pond for staging... }\end{array}$ & $\begin{array}{l}\text { The open area was not utilized for } \\
\text { stabilizing of sediment. }\end{array}$ & $\begin{array}{l}\text { Sediment was stabilized and } \\
\text { stored in the pond then } \\
\text { stockpiled on a } 20 \text { mil thick } \\
\text { polyethylene plastic sheet over } \\
\text { the settling basin at the east } \\
\text { comer of the pond prior to } \\
\text { transportation off location. }\end{array}$ \\
\hline 2 & $\begin{array}{l}\text { CAP, } 3.2 \\
\text { Para. } 2 \\
\text {. }\end{array}$ & $\begin{array}{l}\text { Stored materials include } \\
\text { stabilizer, } 3 / 4 \text {-in. stone... }\end{array}$ & $\begin{array}{l}\text { The staging area was not used for } \\
\text { storage of a water treatment } \\
\text { system because it was not utilized } \\
\text { during the remediation activity. Kiln } \\
\text { dust, used to stabilize the } \\
\text { sediment, was stored in the pond. } \\
\text { prior to mixing. }\end{array}$ & $\begin{array}{l}\text { Groundwater infiltrating into the } \\
\text { dewatering trench during } \\
\text { sediment stabilization and } \\
\text { removal was below permitted } \\
\text { discharge limits and did not } \\
\text { require treatment. It was more } \\
\text { efficient to store kiln dust in the } \\
\text { pond. }\end{array}$ \\
\hline 3 & $\begin{array}{l}\text { CAP, } 3.2 \\
\text { Para. } 4\end{array}$ & $\begin{array}{l}\text { Preliminary drying of the } \\
\text { sediments will occur... }\end{array}$ & $\begin{array}{l}\text { No drying of the sediment or } \\
\text { capturing of excess water from the } \\
\text { sediment was required. }\end{array}$ & $\begin{array}{l}\text { Excess water was absorbed by } \\
\text { the kiln dust used to stabilize } \\
\text { the sediment. }\end{array}$ \\
\hline 4 & $\begin{array}{l}\text { CAP, } 3.3 \\
\text { Para. } 1\end{array}$ & $\begin{array}{l}\text { Fish and salamanders will be } \\
\text { removed from the pond... }\end{array}$ & $\begin{array}{l}\text { Twenty-five fish were removed by } \\
\text { capturing them with barbless hooks } \\
\text { and then transporting them to a } \\
\text { nearby beaver pond. No } \\
\text { salamanders were observed. }\end{array}$ & $\begin{array}{l}\text { No effective method was found } \\
\text { to stun the fish using either } \\
\text { ichthycides or electricity without } \\
\text { stirring up contaminated } \\
\text { sediments from the pond } \\
\text { bottom, resulting in water } \\
\text { disposal problems. }\end{array}$ \\
\hline 5 & $\begin{array}{l}\text { CAP, } 3.4 \\
\text { Para. } 1\end{array}$ & $\begin{array}{l}\text { Drainage of the pond will be } \\
\text { required for sediment } \\
\text { removal... }\end{array}$ & $\begin{array}{l}\text { Gasoline powered pumps were } \\
\text { used. Discharge hoses were } \\
\text { placed in the riprap-lined pond } \\
\text { spillway that discharged into the } \\
\text { nearby stream ("Hayward Creek"). }\end{array}$ & $\begin{array}{l}\text { Gasoline powered pumps were } \\
\text { more readily available than } \\
\text { diesel powered pumps. Water } \\
\text { was discharged to the vegetated } \\
\text { riprap to minimize stream } \\
\text { erosion and remove suspended } \\
\text { material. }\end{array}$ \\
\hline 6 & $\begin{array}{l}\text { CAP, } 3.4 \\
\text { Para. } 2\end{array}$ & $\begin{array}{l}\text { Prior to pond drainage, the } \\
\text { inlet to the pond will be } \\
\text { blocked... }\end{array}$ & $\begin{array}{l}\text { The spring flow was diverted from } \\
\text { flowing into the pond by damming } \\
\text { the inlet channel to the pond and } \\
\text { draining collected water into the } \\
\text { nearby stream through a 4-inch } \\
\text { flexible pipe. }\end{array}$ & $\begin{array}{l}\text { This engineering solution was } \\
\text { deemed in the field to be } \\
\text { simpler and more cost effective } \\
\text { than the original plan. }\end{array}$ \\
\hline 7 & $\begin{array}{l}\text { CAP, } 3.4 \\
\text { Para. } 5\end{array}$ & $\begin{array}{l}\text { After removing the majority of } \\
\text { the pond water... }\end{array}$ & $\begin{array}{l}\text { Water remaining in the pond after } \\
\text { initial pond dewatering was } \\
\text { stabilized with kiln dust. }\end{array}$ & $\begin{array}{l}\text { Stabilizing the water with the } \\
\text { sediment was cheaper and } \\
\text { more practical than moving in } \\
\text { Baker tanks and installing a } \\
\text { water treatment system. }\end{array}$ \\
\hline 8 & $\begin{array}{l}\text { CAP, } 3.4 \\
\text { Para. } 5\end{array}$ & $\begin{array}{l}\text { After removing the majority of } \\
\text { the pond water... }\end{array}$ & $\begin{array}{l}\text { No produced water was pumped to } \\
\text { Baker tanks for treatment or } \\
\text { disposal. }\end{array}$ & See above rationale. \\
\hline
\end{tabular}


Table A-1

Corrective Action Plan Variances

(Page 2 of 3 )

\begin{tabular}{|c|c|c|c|c|}
\hline $\begin{array}{l}\text { Variance } \\
\text { Number }\end{array}$ & $\begin{array}{l}\text { Document } \\
\text { Section }\end{array}$ & $\begin{array}{l}\text { Original Technical } \\
\text { Approach }\end{array}$ & Actual Technical Activity & Rationale for Change \\
\hline 9 & $\begin{array}{l}\text { CAP, } 3.4 \\
\text { Para. } 6\end{array}$ & $\begin{array}{l}\text { If the water in the Baker } \\
\text { tanks does not pass... }\end{array}$ & $\begin{array}{l}\text { No water treatment system was } \\
\text { utilized. }\end{array}$ & See above rationale. \\
\hline 10 & $\begin{array}{l}\text { CAP, } 3.4 \\
\text { Para. } 8\end{array}$ & $\begin{array}{l}\text { During pond drainage } \\
\text { activities... }\end{array}$ & $\begin{array}{l}\text { The groundwater levels were not } \\
\text { monitored. }\end{array}$ & $\begin{array}{l}\text { The sump excavated into the } \\
\text { pond bottom adequately } \\
\text { handled infiltrating groundwater, } \\
\text { so the well points proposed in } \\
\text { the CAP were not needed. }\end{array}$ \\
\hline 11 & $\begin{array}{l}\text { CAP, } 3.4 \\
\text { Para. } 8\end{array}$ & $\begin{array}{l}\text { The hydraulic characteristics } \\
\text { of soils... }\end{array}$ & $\begin{array}{l}\text { The hydraulic characteristics were } \\
\text { not determined prior to draining the } \\
\text { pond. }\end{array}$ & $\begin{array}{l}\text { The sump excavated into the } \\
\text { pond bottom adequately } \\
\text { handled infiltrating groundwater, } \\
\text { so the well points proposed in } \\
\text { the CAP were not needed. . }\end{array}$ \\
\hline 12 & $\begin{array}{l}\text { CAP, } 3.4 \\
\text { Para. } 8\end{array}$ & $\begin{array}{l}\text { If construction dewatering is } \\
\text { determined to be... }\end{array}$ & $\begin{array}{l}\text { A dewatering trench was installed } \\
\text { along the southwest (upgradient) } \\
\text { pond wall after the sediment was } \\
\text { stabilized. The trench was installed } \\
\text { to intercept groundwater infiltrating } \\
\text { into the pond from upgradient. }\end{array}$ & $\begin{array}{l}\text { Because it became necessary } \\
\text { to remove soil from below the } \\
\text { water table, the dewatering } \\
\text { trench was deemed the best } \\
\text { and most cost-effective } \\
\text { engineering solution to control } \\
\text { groundwater infiltration. }\end{array}$ \\
\hline 13 & $\begin{array}{l}\text { CAP, } 3.5 \\
\text { Para. } 3\end{array}$ & $\begin{array}{l}\text { Sediment drying would best } \\
\text { be accomplished... }\end{array}$ & $\begin{array}{l}\text { Sediment drying activity with } \\
\text { associated water handling and } \\
\text { treatment was not performed. The } \\
\text { sediment was stabilized in the } \\
\text { pond, using kiln dust. }\end{array}$ & $\begin{array}{l}\text { Stabilizing all of the material } \\
\text { was better and did not require } \\
\text { much more stabilizer than would } \\
\text { be needed to stabilize the } \\
\text { "dewatered" sediment, and it } \\
\text { would require less time. }\end{array}$ \\
\hline 14 & $\begin{array}{l}\text { CAP, } 3.5 \\
\text { Para. } 4\end{array}$ & The pond will be covered... & $\begin{array}{l}\text { The pond was not covered during } \\
\text { precipitation events. }\end{array}$ & $\begin{array}{l}\text { Covering the pond with plastic } \\
\text { sheeting was impractical and } \\
\text { would have resulted in the } \\
\text { generation of large quantities of } \\
\text { contaminated plastic. }\end{array}$ \\
\hline 15 & $\begin{array}{l}\text { CAP, } 3.6 \\
\text { Para. } 3\end{array}$ & $\begin{array}{l}\text { The sediment will be blended } \\
\text { with a pug mill... } \\
\text {. }\end{array}$ & $\begin{array}{l}\text { A pug mill was not used to blend } \\
\text { the sediments. The sediments } \\
\text { were mixed in place using two } \\
\text { excavators. }\end{array}$ & $\begin{array}{l}\text { This engineering solution was } \\
\text { deemed in the field to be } \\
\text { simpler, faster, and more cost- } \\
\text { effective than the original plan. }\end{array}$ \\
\hline 16 & $\begin{array}{l}\text { CAP, } 3.6 \\
\text { Para. } 3\end{array}$ & $\begin{array}{l}\text { Following sampling, the } \\
\text { resulting stabilized mixture... }\end{array}$ & $\begin{array}{l}\text { The stabilized sediment was stored } \\
\text { in the pond itself or stockpiled over } \\
\text { the settling basin adjacent to the } \\
\text { east corner of the pond for } \\
\text { approximately } 48 \text { hours prior to } \\
\text { transport off site for disposal. This } \\
\text { time period was based on receiving } \\
\text { laboratory analyses confirming } \\
\text { stabilization of the contaminants of } \\
\text { concern. }\end{array}$ & $\begin{array}{l}\text { This change in plan was by } \\
\text { State of Colorado Waste } \\
\text { Management Division as } \\
\text { acceptance criteria for } \\
\text { classification of the stabilized } \\
\text { sediment as solid waste. It was } \\
\text { put into place after the CAP was } \\
\text { written. }\end{array}$ \\
\hline 17 & $\begin{array}{l}\text { CAP, } 3.6 \\
\text { Para. } 4\end{array}$ & $\begin{array}{l}\text { Vendors who market } \\
\text { proprietary stabilizers... }\end{array}$ & $\begin{array}{l}\text { No bench top studies were } \\
\text { conducted. Cement and kiln dust } \\
\text { were tested in the field. Kiln dust } \\
\text { was selected for use in stabilizing } \\
\text { the sediment. }\end{array}$ & $\begin{array}{l}\text { The kiln dust was as effective as } \\
\text { cement in stabilizing the } \\
\text { sediment and less costly than } \\
\text { cement. }\end{array}$ \\
\hline 18 & $\begin{array}{l}\text { CAP, } 3.6 \\
\text { Para. } 5\end{array}$ & $\begin{array}{l}\text { The bench test will also } \\
\text { determine how chromium... }\end{array}$ & $\begin{array}{l}\text { A bench top partition test was not } \\
\text { performed on the sediment and } \\
\text { water. }\end{array}$ & $\begin{array}{l}\text { The kiln dust bound the water in } \\
\text { the sediment. There was no } \\
\text { partition of the sediment and } \\
\text { water. }\end{array}$ \\
\hline
\end{tabular}


Table A-1

Corrective Action Plan Variances

(Page 3 of 3 )

\begin{tabular}{|c|c|c|c|c|}
\hline $\begin{array}{l}\text { Variance } \\
\text { Number }\end{array}$ & $\begin{array}{l}\text { Document } \\
\text { Section }\end{array}$ & $\begin{array}{l}\text { Original Technical } \\
\text { Approach }\end{array}$ & Actual Technical Activity & Rationale for Change \\
\hline 19 & $\begin{array}{l}\text { CAP, } 3.7 \\
\text { Para. } 1\end{array}$ & $\begin{array}{l}\text { Following removal of the } \\
\text { sediment, confirmatory... } \\
\text {. }\end{array}$ & $\begin{array}{l}\text { The TPH cleanup standard was } \\
\text { increased from } 250 \text { milligrams per } \\
\text { kilogram to } 1,000 \text { milligrams per } \\
\text { kilogram. }\end{array}$ & $\begin{array}{l}\text { Verbal authorization was } \\
\text { received from the State of } \\
\text { Colorado on October } 12,1995 \\
\text { to raise the cleanup level to } \\
1,000 \text { milligrams per kilogram in } \\
\text { the pond sediments. State of } \\
\text { Colorado correspondence } \\
\text { documenting the verbal } \\
\text { authorization was received by } \\
\text { DOE on June } 7,1996 \\
\text { (see Appendix E). }\end{array}$ \\
\hline 20 & $\begin{array}{l}\text { CAP, } 3.8 \\
\text { Para. } 2\end{array}$ & $\begin{array}{l}\text { Following the installation of } \\
\text { the pond liner... }\end{array}$ & $\begin{array}{l}\text { Spring flow into the pond was not } \\
\text { restored at the conclusion of } \\
\text { remediation activities in November } \\
\text { 1995. }\end{array}$ & $\begin{array}{l}\text { The land owner did not have } \\
\text { ownership of the water rights to } \\
\text { the spring. }\end{array}$ \\
\hline 21 & $\begin{array}{l}\text { CAP, } 3.8 \\
\text { Para. } 3\end{array}$ & $\begin{array}{l}\text { A critical aspect of pond } \\
\text { restoration... }\end{array}$ & $\begin{array}{l}\text { The pond liner was covered with } \\
\text { Kentucky bluegrass sod. The pond } \\
\text { was not restocked with trout. }\end{array}$ & $\begin{array}{l}\text { Natural vegetation could not be } \\
\text { reestablished, nor could the } \\
\text { trout be restocked because the } \\
\text { pond was not refilled with water. }\end{array}$ \\
\hline 22 & $\begin{array}{l}\text { CAP, } 3.9 \\
\text { Para. } 3\end{array}$ & $\begin{array}{l}\text { Eight groundwater monitoring } \\
\text { wells are planned... }\end{array}$ & $\begin{array}{l}\text { Seven groundwater monitoring } \\
\text { wells were installed at the Rulison } \\
\text { site. }\end{array}$ & $\begin{array}{l}\text { One of two planned hydraulically } \\
\text { upgradient monitoring wells was } \\
\text { eliminated. One well was } \\
\text { enough to provide the } \\
\text { necessary background } \\
\text { groundwater quality } \\
\text { information. }\end{array}$ \\
\hline 23 & $\begin{array}{l}\text { CAP, } 3.9 \\
\text { Para. } 4\end{array}$ & $\begin{array}{l}\text { Two methods of monitoring } \\
\text { well installation... }\end{array}$ & $\begin{array}{l}\text { The wells were not installed by a } \\
\text { State of Colorado-licensed well } \\
\text { driller. }\end{array}$ & $\begin{array}{l}\text { It is not necessary for } \\
\text { environmental monitoring wells } \\
\text { to be installed in the State of } \\
\text { Colorado by a licensed well } \\
\text { driller per Colorado } \\
2 \text { CCR-402-2, Paragraph } 7.1 \text {. }\end{array}$ \\
\hline 24 & $\begin{array}{l}\text { CAP, } 3.9 \\
\text { Para. } 4\end{array}$ & $\begin{array}{l}\text { The wells downgradient of } \\
\text { the pond... }\end{array}$ & $\begin{array}{l}\text { The wells were dug using shovels } \\
\text { and a pry bar. }\end{array}$ & $\begin{array}{l}\text { The soil was too rocky to hand } \\
\text { auger or to use a portable } \\
\text { motorized auger. }\end{array}$ \\
\hline 25 & $\begin{array}{l}\text { CAP, } 3.9 \\
\text { Para. } 5\end{array}$ & $\begin{array}{l}\text { The upgradient wells will be } \\
\text { constructed... }\end{array}$ & $\begin{array}{l}\text { Three of the wells located down- } \\
\text { gradient of the drilling effluent pond } \\
\text { and one well located down-gradient } \\
\text { of emplacement hole R-E were } \\
\text { constructed of 4-inch Schedule } 40 \\
\text { PVC. The well located upgradient } \\
\text { of the drilling effluent pond, one } \\
\text { well located downgradient of the } \\
\text { drilling effluent pond and one well } \\
\text { down- gradient of emplacement } \\
\text { hole R-E were constructed of 5- } \\
\text { inch Schedule } 40 \text { PVC. }\end{array}$ & $\begin{array}{l}\text { The well designs were changed } \\
\text { to reflect revised objectives for } \\
\text { the well and to accommodate } \\
\text { available testing equipment. }\end{array}$ \\
\hline 26 & $\begin{array}{l}\text { CAP, } 3.9 \\
\text { Para. } 7\end{array}$ & $\begin{array}{l}\text { The filter pack will consist of } \\
\text { washed and graded... }\end{array}$ & $\begin{array}{l}\text { A } 16 / 32 \text {-sized filter pack instead of } \\
20 / 40 \text { was installed in the } \\
\text { groundwater monitoring wells. }\end{array}$ & $\begin{array}{l}\text { The slot size opening for the } \\
\text { PVC well screens was } \\
0.02 \text { inch. The filter pack was } \\
\text { changed to be compatible with } \\
\text { this slot size opening. }\end{array}$ \\
\hline
\end{tabular}

PVC $=$ Polywinyl chloride 
Table A-2

Verification Sampling and Analysis Plan Variances

(Page 1 of 2)

\begin{tabular}{|c|c|c|c|c|}
\hline $\begin{array}{l}\text { Variance } \\
\text { Number }\end{array}$ & $\begin{array}{l}\text { Document } \\
\text { Section }\end{array}$ & $\begin{array}{c}\text { Original Technical } \\
\text { Approach }\end{array}$ & Actual Technical Activity & Rationale for Change \\
\hline 1 & $\begin{array}{l}\text { VSAP, } 1.3 \\
\text { Para. } 1 \\
\text { Sen. } 5\end{array}$ & $\begin{array}{l}\text { Third, it is anticipated that as } \\
\text { water drainage from the } \\
\text { pond... }\end{array}$ & $\begin{array}{l}\text { Water remaining in the pond after } \\
\text { pond drainage was mixed with kiln } \\
\text { dust stabilizer and taken to the } \\
\text { landfill for disposal with the other } \\
\text { stabilized sediment. }\end{array}$ & $\begin{array}{l}\text { This engineering solution was } \\
\text { deemed in the field to be } \\
\text { simpler and more cost-effective } \\
\text { than the original plan. }\end{array}$ \\
\hline 2 & $\begin{array}{l}\text { VSAP, } 1.3 \\
\text { Para. } 2 \\
\text { Bullet } 6\end{array}$ & $\begin{array}{l}\text { Water samples will be } \\
\text { analyzed for whole effluent } \\
\text { toxicity... }\end{array}$ & $\begin{array}{l}\text { This analyses performed on water } \\
\text { drained from the pond were organic } \\
\text { toxic pollutants (OTP), total } \\
\text { suspended solids (TSS), total } \\
\text { dissolved solids (TDS), pH, total } \\
\text { petroleum hydrocarbons (TPH), } \\
\text { benzene, toluene ethyl benzene } \\
\text { xylene (BTEX), potentially dissolved } \\
\text { lead (Pb), total mercury (Hg), \& total } \\
\text { recoverable chromium (Cr), iron } \\
\text { (Fe) \& zinc (Zn). }\end{array}$ & $\begin{array}{l}\text { All the analyses except for } \\
\text { whole effluent toxicity (WET) } \\
\text { were specified in the State of } \\
\text { Colorado discharge permit. } \\
\text { Because there were trout living } \\
\text { in the pond, the State } \\
\text { determined that WET analysis } \\
\text { was not needed. }\end{array}$ \\
\hline 3 & $\begin{array}{l}\text { VSAP, } 1.3 \\
\text { Para. } 3 \\
\text { Bullet } 1\end{array}$ & $\begin{array}{l}\text { The sediment will be mixed } \\
\text { with a pug mill... }\end{array}$ & $\begin{array}{l}\text { A pug mill was not used to mix the } \\
\text { sediments. The sediments were } \\
\text { mixed in place in the pond using two } \\
\text { excavators. }\end{array}$ & $\begin{array}{l}\text { This engineering solution was } \\
\text { deemed in the field to be } \\
\text { simpler and more cost-effective } \\
\text { than the original plan. }\end{array}$ \\
\hline 4 & $\begin{array}{l}\text { VSAP, } 1.3 \\
\text { Para. } 3 \\
\text { Bullet } 3\end{array}$ & $\begin{array}{l}\text { Stabilized sediment will be } \\
\text { analyzed for... }\end{array}$ & $\begin{array}{l}\text { The laboratory analyses performed } \\
\text { on the stabilized sediment were } \\
\text { Toxicity Characteristic Leaching } \\
\text { Procedure (TCLP) Chromium, TPH, } \\
\text { and TCLP.Benzene. Paint filter and } \\
\text { pH tests were performed on the. } \\
\text { stabilized sediment.in the field. }\end{array}$ & $\begin{array}{l}\text { The paint filter test was } \\
\text { required by the State of } \\
\text { Colorado for disposal } \\
\text { purposes. The pH tests were } \\
\text { performed to insure that the pH } \\
\text { of the stabilized sediment was } \\
\text { high enough to render metals } \\
\text { immobile and to meet landfill } \\
\text { requirements. }\end{array}$ \\
\hline 5 & $\begin{array}{l}\text { VSAP, } 1.3 \\
\text { Para. } 5 \\
\text { Bullet } 4\end{array}$ & $\begin{array}{l}\text { Soil samples will be analyzed } \\
\text { for total TCLP RCRA } \\
\text { Metals... }\end{array}$ & $\begin{array}{l}\text { Soil samples were analyzed for } \\
\text { TCLP RCRA metals, TPH and } \\
\text { TCLP benzene. }\end{array}$ & $\begin{array}{l}\text { The instructions used by field } \\
\text { sampling personnel during } \\
\text { verification sampling specifled } \\
\text { that samples were to be } \\
\text { analyzed for TCLP benzene } \\
\text { and TCLP metals. }\end{array}$ \\
\hline 6 & $\begin{array}{l}\text { VSAP, } 1.3 \\
\text { Para. } 4\end{array}$ & $\begin{array}{l}\text { The proposed approach for } \\
\text { sampling water that may... }\end{array}$ & $\begin{array}{l}\text { Potentially contaminated water was } \\
\text { not pumped to Baker tanks; } \\
\text { therefore, no sampling of this water } \\
\text { occurred. All potentially } \\
\text { contaminated water was mixed with } \\
\text { kiln dust stabilizer and analyzed as } \\
\text { stabilized sediment. }\end{array}$ & $\begin{array}{l}\text { This engineering solution was } \\
\text { deemed in the field to be } \\
\text { simpler and more cost-effective } \\
\text { than the original plan. }\end{array}$ \\
\hline 7 & $\begin{array}{l}\text { VSAP, } 5.2 \\
\text { Para. } 1 \\
\text { Bullet } 1\end{array}$ & $\begin{array}{l}\text { Sample will be collected from } \\
\text { the pond prior to initiating } \\
\text { discharge... }\end{array}$ & $\begin{array}{l}\text { No samples were collected and } \\
\text { analyzed for Whole Effluent } \\
\text { Toxicity. }\end{array}$ & $\begin{array}{l}\text { See Technical Change number } \\
2 \text { above. }\end{array}$ \\
\hline
\end{tabular}


Table A-2

Verification Sampling and Analysis Plan Variances

(Page 2 of 2)

\begin{tabular}{|c|c|c|c|c|}
\hline $\begin{array}{l}\text { Variance } \\
\text { Number }\end{array}$ & $\begin{array}{l}\text { Document } \\
\text { Section }\end{array}$ & $\begin{array}{l}\text { Original Technical } \\
\text { Approach }\end{array}$ & Actual Technical Activity & Rationale for Change \\
\hline 8 & $\begin{array}{l}\text { VSAP, } 5.2 \\
\text { Para. } 1 \\
\text { Bullet } 2\end{array}$ & $\begin{array}{l}\text { One sample will be collected } \\
\text { at the beginning... } \\
\text {.. }\end{array}$ & $\begin{array}{l}\text { The analyses performed on the } \\
\text { water sample collected at the } \\
\text { beginning of pond drainage } \\
\text { activities were TSS, TDS, pH, TPH, } \\
\text { BTEX, Potentially Dissolved Lead, } \\
\text { Total Hg, and Total Recoverable Cr, } \\
\text { Fe and } \mathrm{Zn} \text {. }\end{array}$ & $\begin{array}{l}\text { These analyses were } \\
\text { stipulated by the State of } \\
\text { Colorado as part of the site } \\
\text { water discharge permit, except } \\
\text { for OTC. The permit was not } \\
\text { available when the VSAP was } \\
\text { prepared. }\end{array}$ \\
\hline 9 & $\begin{array}{l}\text { VSAP, } 5.2 \\
\text { Para. } 1 \\
\text { Bullet } 3\end{array}$ & $\begin{array}{l}\text { At midpoint of draining the } \\
\text { pond, one sample will be ... }\end{array}$ & $\begin{array}{l}\text { The analyses performed on the } \\
\text { water sample collected at the } \\
\text { midpoint of pond drainage activities } \\
\text { were OTC, TSS, TDS, pH, TPH, } \\
\text { BTEX, Potentially Dissolved Lead, } \\
\text { Total } \mathrm{Hg} \text {, and Total Recoverable } \mathrm{Cr} \text {, } \\
\text { Fe and } \mathrm{Zn} \text {. }\end{array}$ & See above rationale. \\
\hline 10 & $\begin{array}{l}\text { VSAP, } 5.2 \\
\text { Para. } 1 \\
\text { Bullet } 4\end{array}$ & $\begin{array}{l}\text { At the endpoint of pond } \\
\text { drainage activity... }\end{array}$ & $\begin{array}{l}\text { The analyses performed on the } \\
\text { water sample collected at the end of } \\
\text { pond drainage activities were TSS, } \\
\text { TDS, pH, TPH, BTEX, Potentially } \\
\text { Dissolved Lead, Total Hg, and Total } \\
\text { Recoverable } \mathrm{Cr} \text {, Fe and } \mathrm{Zn} \text {. }\end{array}$ & See above rationale. \\
\hline 11 & $\begin{array}{l}\text { VSAP, } 5.3 \\
\text { Para. } 1 \\
\text { Sen. } 3\end{array}$ & $\begin{array}{l}\text { Approximately } 3,000 \text { cubic } \\
\text { yards }\left(y d^{3}\right) \ldots\end{array}$ & $\begin{array}{l}\text { The actual volume of stabilized } \\
\text { sediment removed from the pond } \\
\text { was } 24,443 \mathrm{yd}^{3} \text {. }\end{array}$ & $\begin{array}{l}\text { Hydrocarbons migrated into the } \\
\text { wall of the dam and further } \\
\text { than expected beneath the } \\
\text { drilling mud into the floor of the } \\
\text { pond. }\end{array}$ \\
\hline 12 & $\begin{array}{l}\text { VSAP, } 5.3 \\
\text { Para. } 1 \\
\text { Sen. }\end{array}$ & $\begin{array}{l}\text { Ten samples of the stabilized } \\
\text { sediment... }\end{array}$ & $\begin{array}{l}\text { The actual number of stabilized } \\
\text { sediment samples collected was } 82 \text {, } \\
\text { corresponding to } 1 \text { sample for every } \\
300 \mathrm{yd}^{3} \text { of stabilized sediment. }\end{array}$ & See above, rationale. \\
\hline 13 & $\begin{array}{l}\text { VSAP, } 5.4 \\
\text { Para. } 1\end{array}$ & $\begin{array}{l}\text { The goal of this sampling task } \\
\text { is to verify... }\end{array}$ & $\begin{array}{l}\text { No treated pond water samples } \\
\text { were analyzed. } \\
\text {. }\end{array}$ & $\begin{array}{l}\text { All excess pond water was } \\
\text { mixed with kiln dust stabilizer } \\
\text { and transported to the landfill. } \\
\text { No analyses were necessary. }\end{array}$ \\
\hline .14 & $\begin{array}{l}\text { VSAP, } 5.5 \\
\text { Para. } 7\end{array}$ & $\begin{array}{l}\text { The sample grid is calculated } \\
\text { from the following... }\end{array}$ & $\begin{array}{l}\text { The number of verification soil } \\
\text { samples collected from the floor of } \\
\text { the pond was increased from } 37 \text { to } \\
55 \text {. Six test holes were dug on the } \\
\text { walls of the pond, with three } \\
\text { samples collected from each pit. }\end{array}$ & $\begin{array}{l}\text { The number of samples was } \\
\text { increased, in response to a } \\
\text { request from a representative } \\
\text { of the Colorado Department of } \\
\text { Health, Solid Waste } \\
\text { Management Division. The } \\
\text { test pits were added when it } \\
\text { was discovered that } \\
\text { hydrocarbons had migrated } \\
\text { into the walls of the pond. }\end{array}$ \\
\hline 15 & $\begin{array}{l}\text { VSAP, } 5.10 \\
\text { Para. } 1\end{array}$ & $\begin{array}{l}\text { The analytical laboratory will } \\
\text { supply sample containers... }\end{array}$ & $\begin{array}{l}\text { The sample containers were } \\
\text { purchased separately. } \\
\text {. }\end{array}$ & $\begin{array}{l}\text { The DOE-specified analytical } \\
\text { laboratory, Rust GeoTech, did } \\
\text { not supply sample containers } \\
\text { for this project. }\end{array}$ \\
\hline
\end{tabular}


Table A-3

Long Term Groundwater Monitoring Plan Variances

(Page 1 of 2)

\begin{tabular}{|c|c|c|c|c|}
\hline $\begin{array}{l}\text { Variance } \\
\text { Number }\end{array}$ & $\begin{array}{l}\text { Document } \\
\text { Section }\end{array}$ & $\begin{array}{l}\text { Original Technical } \\
\text { Approach }\end{array}$ & Actual Technical Activity & Rationale for Change \\
\hline 1 & $\begin{array}{l}\text { LTGMP } 1.0 \\
\text { Para. } 1 \\
\text { Sec. } 1.4 \\
\text { Para. } 1 \\
\text { Sen. } 4 \\
\text { Sec. } 2.1 .1 \\
\text { Para. } 1 \\
\text { Sac. } 5.0 \\
\text { Para. } 1\end{array}$ & $\begin{array}{l}\text { The purpose of this } \\
\text { groundwater... }\end{array}$ & $\begin{array}{l}\text { A total of seven monitoring wells } \\
\text { were installed during the } \\
\text { remediation of the Rulison Drilling } \\
\text { Effluent Pond Site. }\end{array}$ & $\begin{array}{l}\text { Two wells upgradient of the } \\
\text { drilling effluent were to be } \\
\text { incorporated into a well point } \\
\text { system. Because of the low } \\
\text { permeability of the aquifer } \\
\text { material, the well point system } \\
\text { was subsequently deemed not } \\
\text { feasible. }\end{array}$ \\
\hline 2 & $\begin{array}{l}\text { LTGMP } 1.4 \\
\text { Para. } 1 \\
\text { Sen. } 2\end{array}$ & $\begin{array}{l}\text { Based on the current } \\
\text { knowledge... }\end{array}$ & $\begin{array}{l}\text { Sediment was stabilized, in-place, } \\
\text { in the floor of the pond }\end{array}$ & $\begin{array}{l}\text { This engineering solution was } \\
\text { deemed in the field to be } \\
\text { simpler and more cost-effective } \\
\text { than the original plan. }\end{array}$ \\
\hline 3 & $\begin{array}{l}\text { LTGMP, } 2.2 \\
\text { Para. } 1\end{array}$ & $\begin{array}{l}\text { The downgradient wells, } \\
\text { because of their location... }\end{array}$ & $\begin{array}{l}\text { Four borings downgradient of the } \\
\text { drilling effluent pond were dug by } \\
\text { hand, and three were sampled. } \\
\text { Monitoring wells were installed in } \\
\text { three of the hand-dug wolls. One } \\
\text { hand-dug well was replaced by a } \\
\text { drilled well. }\end{array}$ & $\begin{array}{l}\text { Only one of the well locations } \\
\text { was readily accessible to the } \\
\text { drill rig. }\end{array}$ \\
\hline 4 & $\begin{array}{l}\text { LTGMP, } 2.2 \\
\text { Para. } 3\end{array}$ & $\begin{array}{l}\text { The upgradient wells will be } \\
\text { constructed of } 4 \text {-inch PVC... }\end{array}$ & $\begin{array}{l}\text { Three downgradient wells were } \\
\text { constructed of } 4 \text {-inch, Schedule } 40 \\
\text { PVC. One upgradient well and one } \\
\text { downgradient well were constructed } \\
\text { of 5-inch, Schedule } 40 \text {.PVC. }\end{array}$ & $\begin{array}{l}\text { The well designs were changed } \\
\text { to reflect revised objectives for } \\
\text { the well and to accommodate } \\
\text { available testing equipment. }\end{array}$ \\
\hline 5 & $\begin{array}{l}\text { LTGMP, } 2.2 \\
\text { Para. } 4\end{array}$ & $\begin{array}{l}\text { Depending on the depth to } \\
\text { water encountered... }\end{array}$ & $\begin{array}{l}\text { Centralizers were not installed in } \\
\text { two monitoring wells }\end{array}$ & $\begin{array}{l}\text { Centralizers are not required } \\
\text { for wells with an annular space } \\
\text { less than } 2.5 \text { inches (State of } \\
\text { Colorado, Water Well } \\
\text { Construction Rules, } 2 \text {-CCR } \\
402-2 \text {, Section 10.4.2) }\end{array}$ \\
\hline 6 & $\begin{array}{l}\text { LTGMP, } 2.2 \\
\text { Para. } 5\end{array}$ & $\begin{array}{l}\text { Because of their location, } \\
\text { the 2-inch wells will use... }\end{array}$ & $\begin{array}{l}\text { The 2-inch wells were replaced with } \\
4 \text { and } 5 \text {-inch wells. } \\
\text {. }\end{array}$ & $\begin{array}{l}\text { The well designs were changed } \\
\text { to reflect revised objectives for } \\
\text { the well and to accommodate } \\
\text { available testing equipment. }\end{array}$ \\
\hline 7 & $\begin{array}{l}\text { LTGMP, } 2.2 \\
\text { Para. } 5\end{array}$ & $\begin{array}{l}\text { A filter pack size of } 20 / 40 \text { is } \\
\text { expected to be appropriate... }\end{array}$ & $\begin{array}{l}\text { A } 16 / 32 \text {-sized filter pack instead of } \\
20 / 40 \text { was installed in the } \\
\text { groundwater monitoring wells. }\end{array}$ & $\begin{array}{l}\text { This change was made based } \\
\text { on information regarding the } \\
\text { grain-size distribution of the } \\
\text { aquifer matrix that was not } \\
\text { available when the CAP was } \\
\text { prepared. }\end{array}$ \\
\hline
\end{tabular}


Table A-3

Long Term Groundwater Monitoring Plan Variances

(Page 2, of 2)

\begin{tabular}{|c|c|c|c|c|}
\hline $\begin{array}{l}\text { Variance } \\
\text { Number }\end{array}$ & $\begin{array}{l}\text { Document } \\
\text { Section }\end{array}$ & $\begin{array}{l}\text { Original Technical } \\
\text { Approach }\end{array}$ & Actual Technical Activity & Rationale for Change \\
\hline 8 & $\begin{array}{l}\text { LTGMP, } 2.4 \\
\text { Para. } 1\end{array}$ & $\begin{array}{l}\text { Drill cuttings, waste } \\
\text { materials from soil } \\
\text { samples... }\end{array}$ & $\begin{array}{l}\text { Uncontaminated drill cuttings from } \\
\text { wells drilled adjacent to the drilling } \\
\text { effluent pond were placed onto } \\
\text { plastic sheeting instead of into } \\
55 \text {-gallon barrels. }\end{array}$ & $\begin{array}{l}\text { This change was proposed by } \\
\text { DOE and approved by the } \\
\text { State of Colorado regulators } \\
\text { after the LTGMP was prepared. } \\
\text { Following completion of each } \\
\text { drill hole, the cuttings were } \\
\text { placed into drums. }\end{array}$ \\
\hline 9 & $\begin{array}{l}\text { LTGMP, } 3.0 \\
\text { Para. } 3.3\end{array}$ & $\begin{array}{l}\text { Groundwater Monitoring } \\
\text { Methodology }\end{array}$ & $\begin{array}{l}\text { Prior to discharging groundwater } \\
\text { during the pumping test, a quick } \\
\text { tumaround groundwater sample } \\
\text { was analyzed for the discharge } \\
\text { parameters specified in the State of } \\
\text { Colorado groundwater discharge } \\
\text { permit. }\end{array}$ & $\begin{array}{l}\text { Although the permit did not } \\
\text { address this activity, the } \\
\text { groundwater sample was } \\
\text { collected and analyzed to verify } \\
\text { that no contaminated water } \\
\text { was discharged to the nearby } \\
\text { stream during the pumping } \\
\text { test. Because of low } \\
\text { production rates, one to less } \\
\text { than three gallons per minute, } \\
\text { all water produced during } \\
\text { pumping was applied to the } \\
\text { land surface. }\end{array}$ \\
\hline 10 & $\begin{array}{l}\text { LGTMP, } \\
7.1 .2 \\
\text { Para. } 1\end{array}$ & $\begin{array}{l}\text { Additional sample volume } \\
\text { will be collected... }\end{array}$ & $\begin{array}{l}\text { An MS/MSD sample was not } \\
\text { collected during the first round } \\
\text { groundwater sampling event in } \\
\text { August } 1995 \text {. }\end{array}$ & $\begin{array}{l}\text { The plan stipulates that the } \\
\text { MS/MSD sample be collected } \\
\text { from an hydraulically } \\
\text { upgradient well. The } \\
\text { upgradient well had not been } \\
\text { installed at the time of this } \\
\text { sampling event. }\end{array}$ \\
\hline 11 & $\begin{array}{l}\text { LTGMP, } \\
7.1 .3 \\
\text { Para. } 1\end{array}$ & $\begin{array}{l}\text { To assess the effectiveness } \\
\text { of the purging... } \\
\end{array}$ & $\begin{array}{l}\text { Distilled water was used to collect } \\
\text { equipment rinsate samples. }\end{array}$ & $\begin{array}{l}\text { Deionized water was not } \\
\text { available at this site. }\end{array}$ \\
\hline 12 & $\begin{array}{l}\text { LTGMP, } \\
7.1 .4 \\
\text { Para. } 1\end{array}$ & $\begin{array}{l}\text { Trip blank samples will be } \\
\text { used during... }\end{array}$ & $\begin{array}{l}\text { Trip blanks were prepared in the } \\
\text { field laboratory. }\end{array}$ & $\begin{array}{l}\text { The analytical laboratory, Rust } \\
\text { GeoTech, did not supply trip } \\
\text { blank samples for this } \\
\text { project. }\end{array}$ \\
\hline
\end{tabular}


Table A-4

Quality Assurance Project Plan Variances

(Page 1 of 1 )

\begin{tabular}{|c|c|c|c|c|}
\hline $\begin{array}{l}\text { Variance } \\
\text { Number }\end{array}$ & $\begin{array}{l}\text { Document } \\
\text { Section }\end{array}$ & $\begin{array}{c}\text { Original Technical } \\
\text { Approach }\end{array}$ & Actual Technical Activity & Rationale for Change \\
\hline 1 & $\begin{array}{c}\text { QAPP C } \\
5.3 \\
\text { Table 5-2 }\end{array}$ & $\begin{array}{l}\text { BTEX by method } 8020 \mathrm{~A} \\
\text { TPH by method } 8015 \mathrm{~A}\end{array}$ & $\begin{array}{l}\text { BTEX by method } 8260 \\
\text { TPH by method } 418.1\end{array}$ & $\begin{array}{l}\text { The analytical laboratory Rust } \\
\text { GeoTech did not have the } \\
\text { capability to perform methods } \\
8020 \mathrm{~A} \text { or } 8015 \mathrm{~A} \text {, as prescribed } \\
\text { in the QAPP. }\end{array}$ \\
\hline 2 & $\begin{array}{l}\text { QAPP C } \\
5.5 .2 .1 \\
\text { Para. } 1\end{array}$ & $\begin{array}{l}\text { Tier I review is essentially a } \\
\text { completeness review... }\end{array}$ & $\begin{array}{l}\text { A partial Tier I review was } \\
\text { conducted in the field. }\end{array}$ & $\begin{array}{l}\text { It was deemed more cost- } \\
\text { effective to have qualified } \\
\text { personnel from the office } \\
\text { review the data and notify field } \\
\text { personnel of any } \\
\text { discrepancies. }\end{array}$ \\
\hline 3 & $\begin{array}{c}\text { QAPP C } \\
5.5 .2 .2 \\
\text { Para. } 1\end{array}$ & $\begin{array}{l}\text { Tier II review shall include a } \\
\text { review... }\end{array}$ & $\begin{array}{l}\text { A partial Tier II review was } \\
\text { conducted in the field. }\end{array}$ & See above rationale. \\
\hline
\end{tabular}




\section{Table A-5 \\ Nonconformances \\ . (Page 1 of 1)}

\begin{tabular}{|c|c|c|c|}
\hline $\begin{array}{l}\text { Nonconformance } \\
\text { Number }\end{array}$ & $\begin{array}{l}\text { Document } \\
\text { Section }\end{array}$ & Nonconformance & Cause \\
\hline 1 & $\begin{array}{l}\text { QAPP, } \\
5.2 .1 \\
\text { Para. } 2\end{array}$ & $\begin{array}{l}\text { Chain of custody } \# 42176 \text { dated } 8 / 7 / 95 \text { was not } \\
\text { signed over to Rust GeoTech laboratory by a } \\
\text { sample team member. However, a sample } \\
\text { team member was in continuous possession of } \\
\text { the samples and was present during transfer } \\
\text { of custody. }\end{array}$ & $\begin{array}{l}\text { Oversight by the personnel delivering the } \\
\text { samples. A sampling team member was } \\
\text { present but the other person delivering the } \\
\text { samples signed the form. }\end{array}$ \\
\hline 283 & $\begin{array}{l}\text { LTGMP, } 2.2 \\
\text { Para. } 4\end{array}$ & $\begin{array}{l}\text { Centralizers were not installed in monitoring } \\
\text { wells RU-6A or RU-2. } \\
\end{array}$ & $\begin{array}{l}\text { The driller was having trouble installing } \\
\text { the well casing with the centralizers } \\
\text { because of the small annular space and } \\
\text { since centralizers are not required for } \\
\text { wells with an annular space less than } 2.5 \\
\text { inches (State of Colorado, Water Well } \\
\text { Construction Rules, 2-CCR } 402-2 \text {, Section } \\
\text { 10.4.2) the casing was installed without } \\
\text { the.centralizers. }\end{array}$ \\
\hline 4 & $\begin{array}{l}\text { VSAP, } 5.5 \\
\text { Para. } 7\end{array}$ & $\begin{array}{l}\text { One-verification sample designated as sample } \\
\text { location \# } 39 \text { was not collected from the floor } \\
\text { of the pond. }\end{array}$ & $\begin{array}{l}\text { The location identified for this sample was } \\
\text { under water so sampling personnel could } \\
\text { not reach it. }\end{array}$ \\
\hline 5 & $\begin{array}{l}\text { VSAP, } 5.7 \\
\text { Para. } 1\end{array}$ & $\begin{array}{l}\text { Total metals analyses were not performed on } \\
\text { verification soil samples collected in the pond } \\
\text { as prescribed in the work plan. }\end{array}$ & $\begin{array}{l}\text { TCLP metals analyses were performed } \\
\text { instead because that is what the State of } \\
\text { Colorado uses to determine if soils need } \\
\text { to be cleaned up. }\end{array}$ \\
\hline 6 & $\begin{array}{l}\text { QAPP, } 1.0 \\
\text { Table } 1-2\end{array}$ & $\begin{array}{l}\text { Duplicate samples were not collected every } \\
\text { day that samples were collected as prescribed } \\
\text { in the work plan. }\end{array}$ & $\begin{array}{l}\text { Duplicate samples were not collected } \\
\text { every day of sampling because only a } \\
\text { small number of samples were collected } \\
\text { on most days and this would have } \\
\text { resulted in an inordinately large number of } \\
\text { duplicate samples and analytical costs. }\end{array}$ \\
\hline
\end{tabular}



Appendix B

Permits 

Roy Romer, Governor

Patti Shwavder, Nating Exceutive Director

Ledicated to protecung and improving tne health ano environment of the people oi Coloracio

$\$ 300$ Cherry Creck Dr. S. . L Loratory Building

Denver. Colorado 80222.1530 4210 E. 11th Avenue

Phone 1303) 692-2000 , Denver, Coloraao 80220-3716

(303) 691.4700

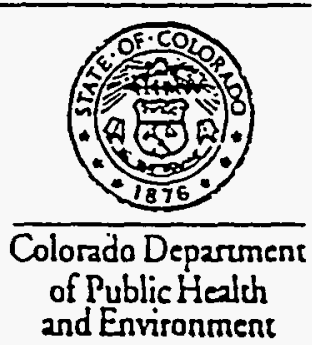

August 14, 1995

U.S. Department of Energy

Roxanne Danz

P.O. Box 98518

Las Vegas, Nevada 89193-8518

CERTIFIED MAIL NO: Z 416968879

RE: Amended Certification, Colorado Wastewater Discharge Permit System: Permit Number: COG310084, U.S. Department of Energy

Dear Ms. Danz:

Enclosed please find a copy of your amended certification which was issued under the Colorado Water Quality Control Act. This permit requires that specific actions be performed at designated times. You are legally obligated to comply with all terms and conditions of the permit. and certifications. It is especially imporant to note the effective date which can be found on page one of the Certification. It is illegal to discharge per the conditions of this permit until that date.

Please read the permit and if you have any questions contact this office at 692-3590.

Sincerely,

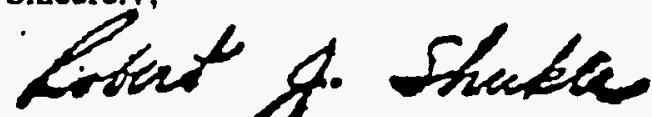

Robert J. Shuk Chief

Permits and Enforcement Section

-Water Quality Control Division

xc: Permits Section, Environmental Protection Agency.

Regional Council of Government

Local County Health Deparment

District Engineer, Field Suppor Section, WQCD

Derald Lang, Field Support Section, WQCD

Permit Drafter, Permits and Enforcement Section, WQCD

Enclosure 


\section{COLORADO DISCHARGE PERMIT SYSTEM AMENDMENT TO THE CERTIFICATION GROUNDWATER CLEANUP OF GASOLINE}

Category 07. Sub-category 8. General Permits. Gasoline cleanup Current fee \$850/year per CRS 25-8-502
- This amendment specifically authorizes.

Page 1

SIC code 1629

\author{
U.S. Department of Energy \\ Roxanne Danz \\ P.O. Box 98518 \\ Las Vegas, Nevada 89193-8518 \\ $(702)+295-7723$
}

with the facility contact of.

Same as above

10 discharge from facility identified as Drilling Effluent Pond project, located in the SW 1/4, Section 25. T7S, R95W; Garfield County as shown in Figure 1 of the permit from discharge points identified as 001-002. as shown in Figure 2 of the Permit and further described in this table.

\begin{tabular}{|c|l|l||}
\hline $\begin{array}{c}\text { Discharge } \\
\text { Point }\end{array}$ & \multicolumn{1}{|c|}{ Description } & $\begin{array}{l}\text { Estimated } \\
\text { Flow Rate }:\end{array}$ \\
\hline \hline $001 \cdot$ & $\begin{array}{l}\text { Discharge from the drilling effluent pond following treatment prior to } \\
\text { entering Hayward Creek. }\end{array}$ & $\begin{array}{l}\text { Avg. }=25 \mathrm{gpm} \\
\text { Max. }=500 \mathrm{gpm}\end{array}$ \\
\hline 002 & $\begin{array}{l}\text { Discharge from the wellpoints following treatment prior to entering Hayward } \\
\text { Creek. }\end{array}$ & $\begin{array}{l}\text { Max. }=150 \mathrm{gpm} \\
\text { Avg. }=75 \mathrm{gpm}\end{array}$ \\
\hline
\end{tabular}

The discharge goes to Hayward Creek, which is within Segment 7. Lower Colorado River Sub-basin, Lower Colorado River Basin, found in 3.7.0 Classifications and Numeric Standards for the Lower Colorado River Basin (5 CCR 1002-8). Segment 7 is classified for the following uses: Recreation. Class 2; Aquatic Life, Class 1 (cold); Agriculture; Water Supply. The Division reviewed this facility on 6/12/95 and determined that the antidegradation presumption was overcome because the discharge is temporary. (I week ).

The activity involves cleanup of sediment contaminated with petroleum hydrocarbons and metals. Surface water showed very low or non-detectable levels of petroleum hydrocarbons and toxic metals. Discharge will be treated by on-site activated carbon filters.

The flow limitation of 0.05 MGD will be waived due to the shor duration of this discharge. 
Results for additional monitoring parameters must be obtained as soon as possible after sampling. If trigger leveis al reacized or crceeded, permittee shall cease discharge and notify the Division immediatelv.

The permittee is encouraged to read the general rationale for an understanding of how this permit was developed and . read the permit to see what requirements exist. Within the body of the permit itself, effluent limitations and monitorit. requirements are specified in Parts I.B and I.C. Best Management Practices are addressed in Pant 1.F.S., and speci - notification requirements for effluent violations are addressed in Pan II.A.2. and II.A.3. Organic Toxic Pollutants in tI volatile fraction (VOC) shall be monitored and the data submitted in the manner described in I.C.4. of the permit. T) first instance of VOC monitoring for this facility shall be within 90 davs of the effective date of this certification.

Salinity (TDS) monitoring of the discharge will be required.

Total Phosphorus monitoring of the discharge will not be required.

Aquatic life Whole Effluent Toxicity (WET) testing will not be required, because of the shor duration of the discharg

Although there is fuel storage in the project area, a Materials Containment Plan will not be required. However, dikit should be perjormed as discussed in Best Management Practices Part I.F.S. of the permit.

Cerification: Based on the above information. the gasoline cleanup facility is certified to discharge under the gener permit for grouniwater cleanup of gasoline, identified as permit number COG-310000. All correspondence relative to th facility should reference the specific facility number, COG-3I0084.

The purpose of this amendment is to ; (I) change the mercury trigger level from 0.01 to 2 ug/l and (2) change the zil trigger level from 2 to 10 ug/l. The original numbers were mistakenly inserted and the new numbers are the intended value Also the permittee has requested that TPH anaiyses, which are routinely being done, be substituted for the Oil \& Grea analyses required by the permit. Since the TPH analysis is more inclusive of petroleum hydrocarbons likely to be found, at the permittee recognizes the limit will remain $10 \mathrm{mg} / \mathrm{l}$, the Division grants this request. The permittee has also requested th the methods used to analyze the samples are need only to provide detection levels that equal or are less than the pern limitations (or trigger levels as the case may be). This is satisfactory with the Division providing the method is EPA approve 


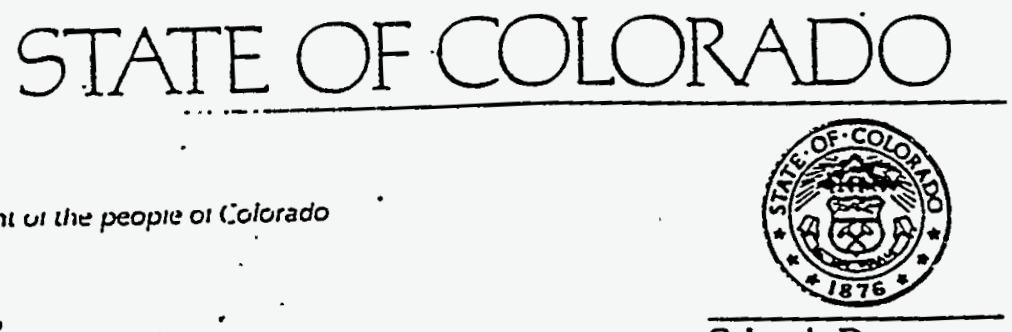

huv Kumes. Guvernur

l'att Shwsvder. scang I xceculive I Jisectut

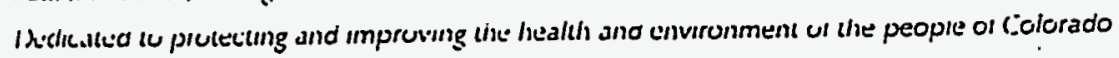

is00 Cherry Crejek Or.S. Luboratory Building

Denver, Culorado $80222-7530$ \$210 E. 11th Avenue

$\begin{array}{ll}\text { l'hone } 13031692.2000 & \text { Denver, Colorsdo } 80220-3716 \\ & \text { (303) 691.4700 }\end{array}$

Colorado Deparment of Public Healch and Environment

June 30,1995

U. 5. Department of Energy

Roxanne Danz

P.O. Box 98518

Las Vegas, Nevada 89193-8518

CERTIFIED MAIL NO: Z 41.6968756

RE: Certification, Colorado Wastewater Discharge Permit System: Permit Number: COG-310084, U.S. Department of EnergY

Dear Ms. Danz:

Enclosed please find a copy of your certification which was issued under the colorado water Quality control Act. This permit requires that specific actions be performed at designated times. You are legally obligated to comply with all terms and conditions of the permit and certifications. It is especially important to note the effective date which can be found on page one of the certification.
It is illegal to discharge per the conditions of this permit until that date.

Please read the permit and if you have any questions contact this office at $692-3590$.

sincerely,

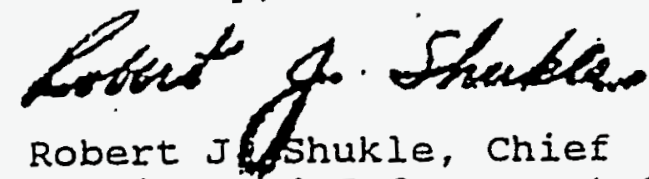

permits and Enforcement Section

water Quality Control Division

xc: Permits Section, Environmental Protection Agency

Regionai Council of Government

Local County Health Department

- District Engineer, Field Support Section, WQCD

Derald Lang, Field Support Section, WQCD

Permit Drafter, permits and Enforcement section, wQCD

Enclosure

RJS: $\mathrm{mIb}$ 


\section{COLORADO DISCHARGE PERMIT SYSTEM \\ CERTIFICATION \\ GROUNDWATER CLEANUP OF GASOLINE}

Page 1

Category 07. Sub-category 8. General Permits, Gasoline cleanup Current fee \$850/year per CRS 25-8-502 SIC code 1629

This permit specifically authorizes, U.S. Department of Energy

Roxanne Danz

P.O. Box 98518

Las Vegas, Nevada 89193-8518

$(702)+295-1113$

with the facility contact of,

Same as above

to discharge from facility identified as Drilling Effluent Pond project, located in the SW 1/4, Section 25, T7S, RS Garfield County as shown in Figure 1 of the permit from discharge points identified as 001-002, as shown in Figure 20 , Permit and further described in this table,

\begin{tabular}{|c|c|c|}
\hline $\begin{array}{l}\text { Discharge } \\
\text { Point }\end{array}$ & 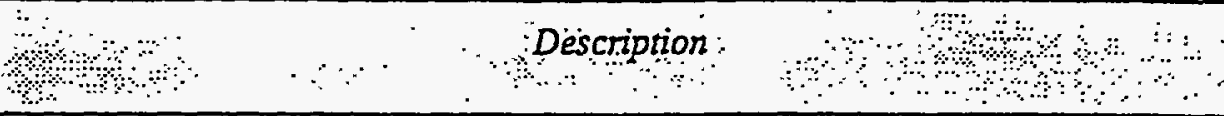 & Estimated \\
\hline 001 & $\begin{array}{l}\text { Discharge from the drilling effluent pond following treatment prior to } \\
\text { entering Hayward Creek. }\end{array}$ & $\begin{array}{l}\text { Avg. }=25 \mathrm{gpm} \\
\text { Max. }=500 \mathrm{gpm}\end{array}$ \\
\hline 002 & $\begin{array}{l}\text { Discharge from the wellpoints following treatment prior to entering Hayward } \\
\text { Creek. }\end{array}$ & $\begin{array}{l}\text { Max. }=150 \mathrm{gpm} \\
\text { Avg. }=75 \mathrm{gpm}\end{array}$ \\
\hline
\end{tabular}

The discharge goes to Hayward Creek, which is within Segment 7, Lower Colorado River Sub-basin, Lower Colorado $R$ Basin, found in 3.7.0 Classifications and Numeric Standards for the Lower Colorado River Basin (5 CCR 1002-8). Segn 7 is classified for the following uses: Recreation. Class 2; Aquatic Life, Class 1 (cold); Agriculture; Water Supply. Division reviewed this facility on $6 / 12 / 95$ and determined that the antidegradation presumption was overcome because discharge is temporary (I week).

The activity involves cleanup of sediment contaminated with petroleum hydrocarbons and metals. Surface water shor very low or non-detectable levels of petroleum hydrocarbons and toxic metals. Discharge will be treated by on-site activa carbon filters.

The flow limitation of 0.05 MGD will be waived due to the short duration of this discharge. 
Page la

Table V-I - Effluent Limits for Discharge Point 001.

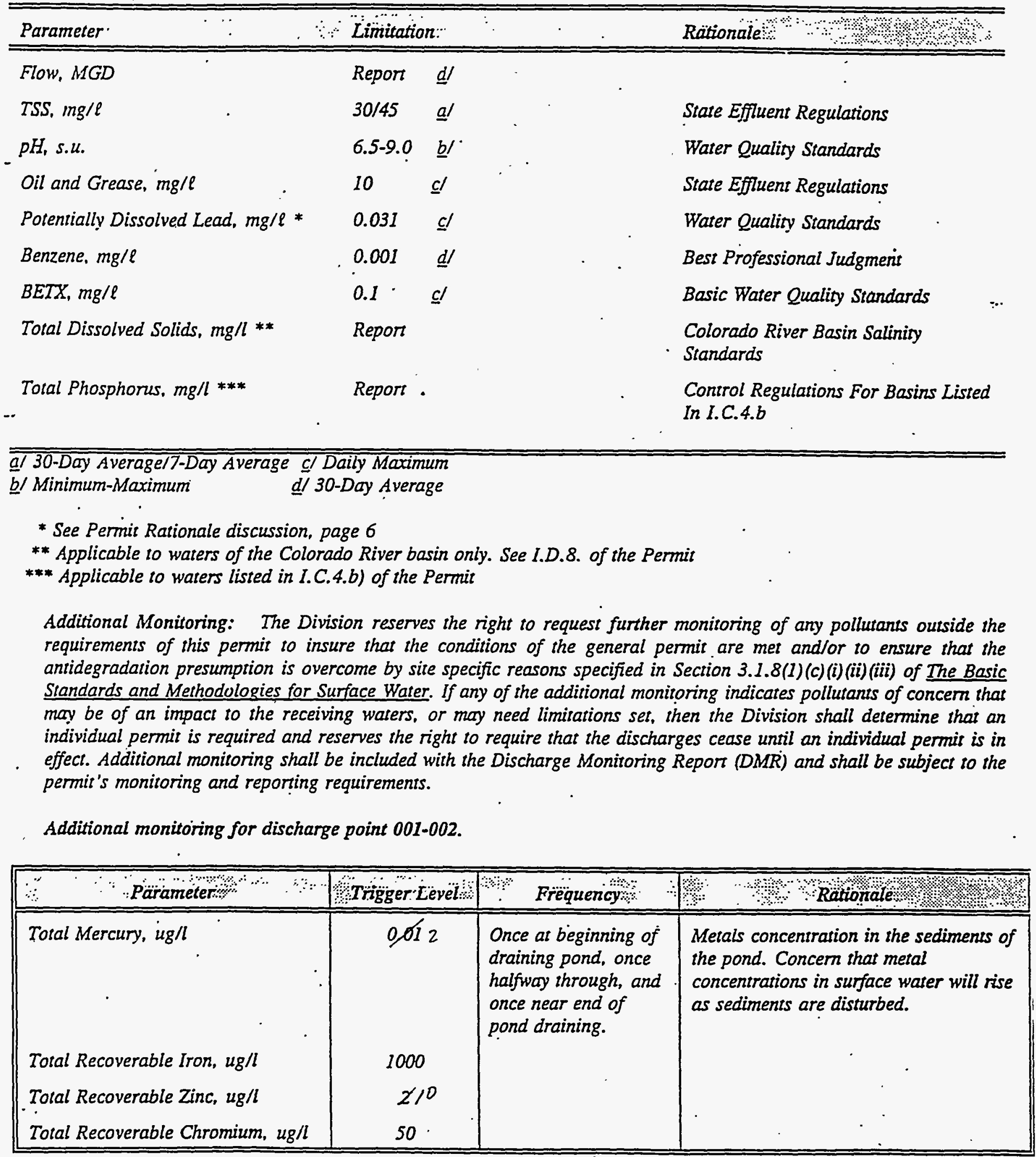


Results for additional monitoring parameters musi be obtained as soon as possible after sampling. If trigger levels reached or exceeded, permittee shall cease discharge and notify the Division immediately.

The permittee is encouraged to read the general rationale for an understanding of how this permit was developed an read the permit to see what requiremients exist. Within the body of the permit itself, effluent limitations and monito requircments are specified in Parts I.B and I.C. Best Management Practices are addressed in Par I.F.5., and spet notificution requirements for effluent violations are addressed in Part II.A.2. and II.A.3. Organic Toxic Pollutants in volatile fraction (VOC) shall be monitored and the data submitted in the manner described in I. C.4. of the permit. : first instance of VOC monitoring for this facility shall be within 90 davs of the effective date of this certification.

Salinity (TDS) monitoring of the discharge will be required.

Total Phosphorts monitoring of the discharge will not be required.

Aquatic life Whole Effluent Toxicity (WET) testing will not be required, because of the short duration of the dischar

Althouyh there is fuel storage in the project area, a Materiais Containment Plan will not be required. However, dik shoulet be performed as discussed in Best Management Präctices Part l.F.5. of the permit.

- Corruficutem: Besved on the above informetion, the sessoline clectnup facility is certified to discharge under the gene permut for groundwater elcanup of gessoline. ielentificad es permit number COG-310000. All correspondence relative this facility should reference the specific facility number. COG-310084.

Tom Boyce

June 12, 1995

Effective 06/30/95 Certified Letter No. Z Z 116968756 . 


\section{CDPS GENERAL PERMIT \\ GROUNDWATER CLEANUP OF GASOLINE \\ AUTHORIZATION TO DISCHARGE UNDER THE \\ COLORADO DISCHARGE PERMIT SYSTEM}

In compliance with the provisious of the Colorado Water Quality Control Act, (25-8-101 et seq., CRS, 1973 as ameaded) and the Federal Water Pollution Control Act, as amended (33 U.S.C. 1251 et seq.; the "Act") facilities performing groundwater cleanup from gasoline contamination are authorized to discharge cleanup water from approved locations throughout the State of Colorado to specified waters of the State. Such discharges shall be in accordance with the conditions of this permit.

This permit specifically authorizes the facility listed on page 1 of this permit to discharge process generated wastewaters, as of this date, in aceordance with the permit requirements and conditions set forth in Parts I and II hereof. All discharges authorized berein shall be consistent with the terms and conditions of this permit.

This permit and the authorization to discharge shall expire at midaight,

March 31, 2000.

Issued and Signed this 13 day of January Effective April 1, 1995

COLORADO DEPARTMENT OF PUBLIC HEALTH AND ENVIRONMENT

J. David Hoim. Director

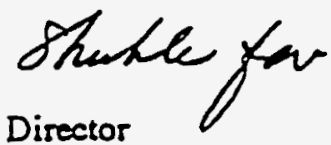

Water Quality Control Division
DFFTIFEED LETHER S

DATE SICHED $01 / 13 / 525$ EFEETHE DRT

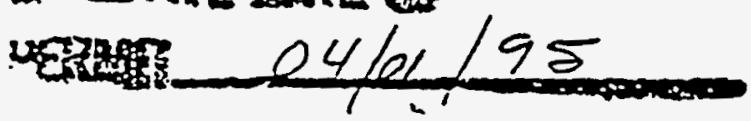


RENEWAL OF

CDPS GENERAL PERMIT RATTONALE

GROUNDWATER CLEANUP OF GASOLINE

AUTHORIZATTON TO DISCHARGE UNDER THE

COLORADO DISCHARGE PERMIT SYSTEM

\section{Updare}

The most significant changes in this renewal are as follows:

A. Total phosphorus monitoring is required for cerzain Wasers of the State Nutrient Loading can lead to algal blooms, which can cause low oxygen situations that degrade the aquaric life habitat and affect the qualisy of the water for warer supply and rectearional purposes. The Waser Quality Control Division has established control regularions for these warerbodies and requires monisoring of discharges for these nutrients. The permit is being modified io include monitoring for Total Phosphorus where required. Paragraph (1.C.4.b.) lists these waters and describes sampling frequency and type.

B. New Language has been added to the WET testing section to allow flexibitity to the permis in dealing with toxicity. These changes bring this permit into agreement with the "Colorado WQCD Biomonitoring Guidance Document Juiy 1, 1993" and are os follows:

1 Language allowing greater flecibility in the determination of frequency or applicability of WET testing for certain facilities has been added. These decisions will be made on the basis of analyzical data, duration of discharge, flow rates or other factors that the Division deems relevant. WET testing requirements and limis are inciuded in Part I.B.2.c) of the permit.

2 The imposition of an acure taxicity limis is included. This defines the conditions that must be met in order to comply with the WET limit.

3 In cases that the Division desermines that WET testing is required. Acute tests rather than Curonic tests will be required due to the low flow rares normally associated with this type of discharge.

4 Language describing the Accelerased sesting, Preliminary Toxiciry Incident, and Taxiciny Identification Evaluation procedures are inciuded in the permit for cases where permintees have failed the WET tests.

C. Review of the EPA RREL 4 date and data from permirted gasoline remediation sires collected over the past five years in Colorado, demonstrates that a limit of $I$ ugh for benzene can and has been achieved by treating benzene consaminased ground water with air stripping andlor granular activared carbon (GAC) systems. 
C. cons.

When air stripping plus GAC is used as treatment for ground water consaining a benzene concentration berween 0 and $100 \mathrm{ug} / \mathrm{l}$, the reporied treated effluent benzene concentration is less than $1.0 \mathrm{ug} / \mathrm{h}$. Typical removal efficiencies appear to be in excess of $90 \%$ and frequently are in excess of $99 \%$, when influens concentrations of berizene $100 \mathrm{ug} / \mathrm{l}$.

Over $90 \%$ (11 out of 12) of the facilities that submined data for benzene in Colorado for the past tub years demonstrated that they could routinely meet a I ug/l benzene limit.

D. Comments during public notice

No written comments were received during the public notice period. No changes were made to the permit or rarionale from the public notice permis.

\section{References}

I. U.S. Environmental Protection Agency. RREL 4 Trearabiliny Darabase.

Cincinnati, Ohio.

II. State of California Regional Water Quality Control Board, Central Valley Region. A Comoilarion of Water Qunlivy Goals. Sacramento. Californiz.

\section{Reauthorization}

Authorization to discharge under this general permit will expire on March 3i, 2000; thus facilities wishing continual coverage under this permit must reapply by September 30, 1999. 


\section{TABLE OF CONTENTS}

\section{PART I}

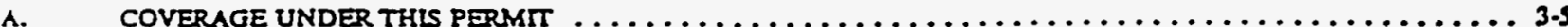

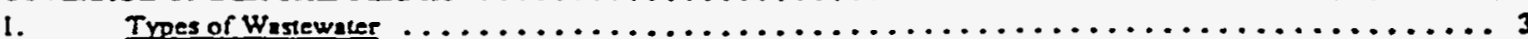

2. Stream Dredgine or Filling $\ldots \ldots \ldots \ldots \ldots \ldots \ldots \ldots \ldots \ldots \ldots \ldots \ldots \ldots \ldots \ldots \ldots \ldots \ldots \ldots \ldots \ldots \ldots \ldots$

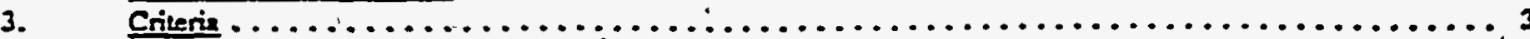

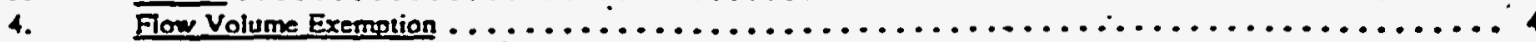

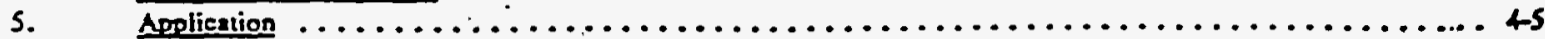

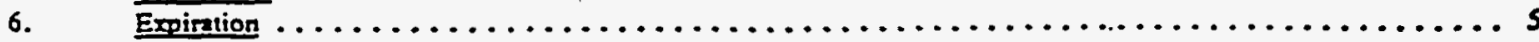

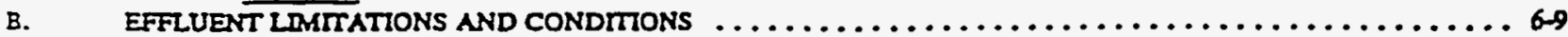

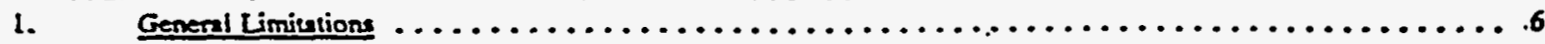

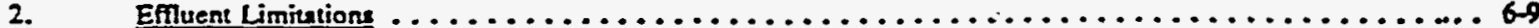

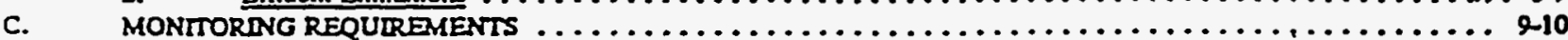

1. Frequency and Stmple Type $\ldots \ldots \ldots \ldots \ldots \ldots \ldots \ldots \ldots \ldots \ldots \ldots \ldots \ldots \ldots \ldots \ldots \ldots \ldots \ldots$

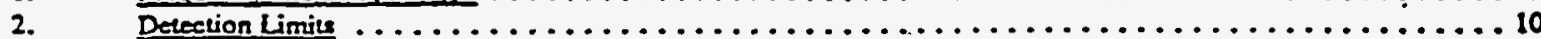

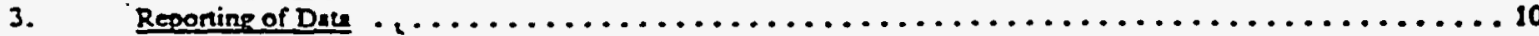

4. Special Monitoring $\ldots \ldots \ldots \ldots \ldots \ldots \ldots \ldots \ldots \ldots \ldots \ldots \ldots \ldots \ldots \ldots \ldots \ldots \ldots \ldots \ldots \ldots \ldots \ldots \ldots 10 \ldots \ldots$

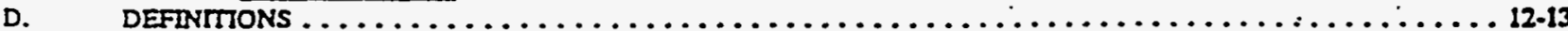

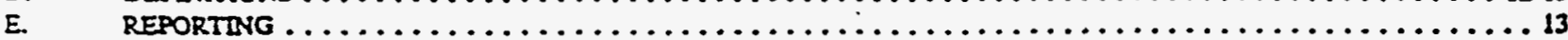

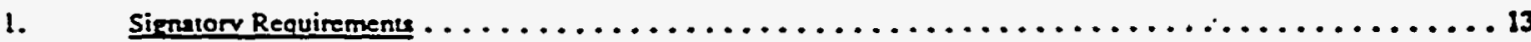

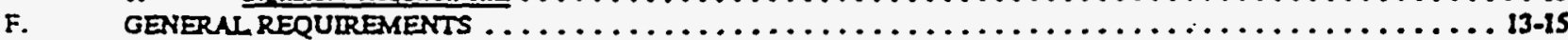

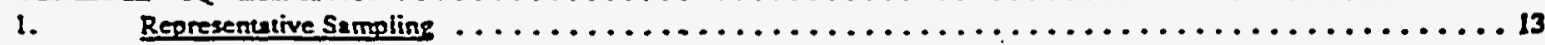

2. Anavical and Semoling Mechods for Monitoring $\ldots \ldots \ldots \ldots \ldots \ldots \ldots \ldots \ldots \ldots \ldots \ldots \ldots \ldots \ldots$

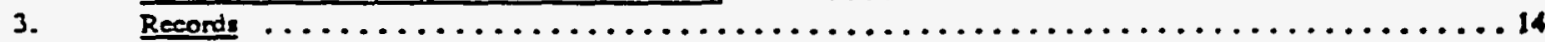

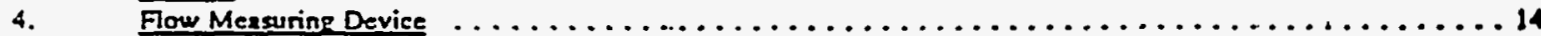

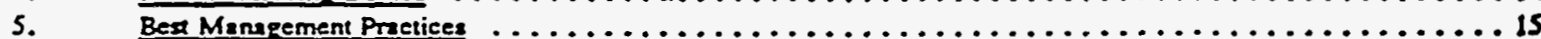

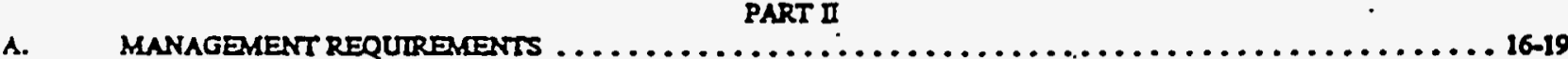

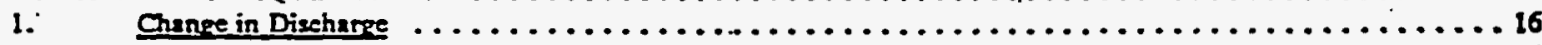

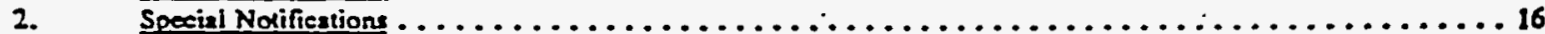

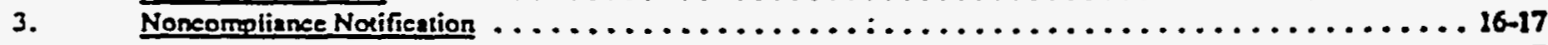

4. Submission of Incorreet of Incomplete Informution $\ldots \ldots \ldots \ldots \ldots \ldots \ldots \ldots \ldots \ldots \ldots \ldots \ldots \ldots \ldots \ldots 17$

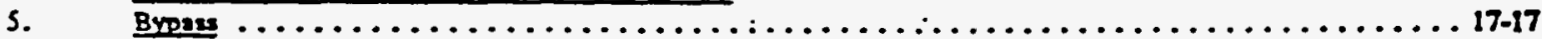

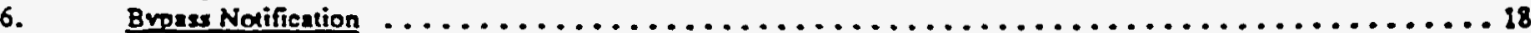

$7 . \quad$ Upress $\ldots \ldots \ldots \ldots \ldots \ldots \ldots \ldots \ldots \ldots \ldots \ldots \ldots \ldots \ldots \ldots \ldots \ldots \ldots \ldots \ldots \ldots \ldots \ldots \ldots \ldots \ldots \ldots \ldots \ldots \ldots \ldots \ldots 18$

8. Removed Subsunces $\ldots \ldots \ldots \ldots \ldots \ldots \ldots \ldots \ldots \ldots \ldots \ldots \ldots \ldots \ldots \ldots \ldots \ldots \ldots \ldots \ldots \ldots \ldots \ldots 19$

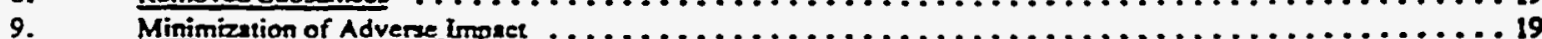

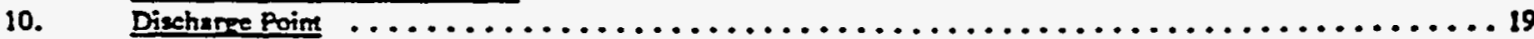

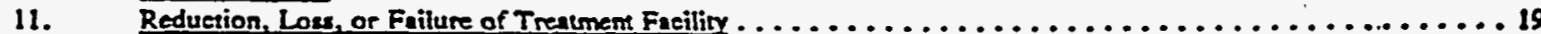

12. Proper Operation and Mainlenance $\ldots \ldots \ldots \ldots \ldots \ldots \ldots \ldots \ldots \ldots \ldots \ldots \ldots \ldots \ldots \ldots \ldots \ldots \ldots$

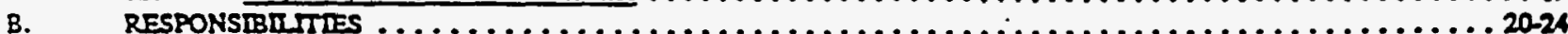

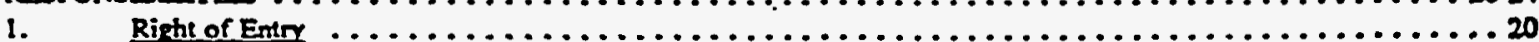

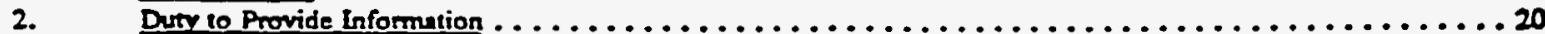

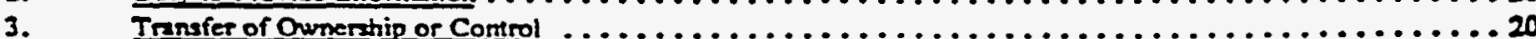

4. Aveilability of Repors $\ldots \ldots \ldots \ldots \ldots \ldots \ldots \ldots \ldots \ldots \ldots \ldots \ldots \ldots \ldots \ldots \ldots \ldots \ldots \ldots \ldots \ldots \ldots \ldots . \ldots \ldots$

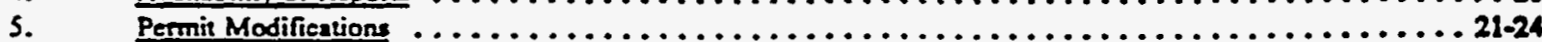

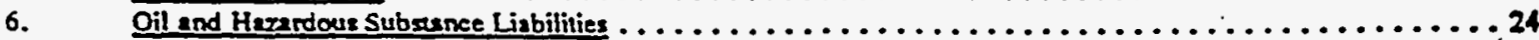

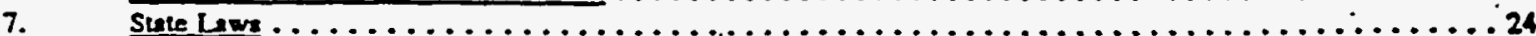

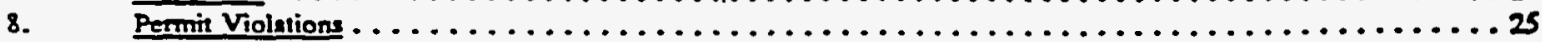

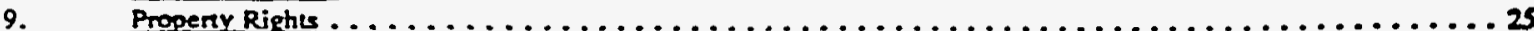

10. Severnbility $\ldots \ldots \ldots \ldots \ldots \ldots \ldots \ldots \ldots \ldots \ldots \ldots \ldots \ldots \ldots \ldots \ldots \ldots \ldots \ldots \ldots \ldots \ldots \ldots \ldots 25$

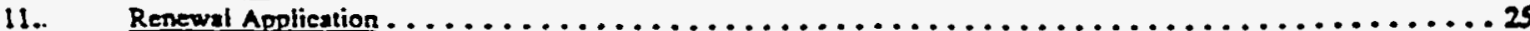

12. $\quad$ Confidemiality $\ldots \ldots \ldots \ldots \ldots \ldots \ldots \ldots \ldots \ldots \ldots \ldots \ldots \ldots \ldots \ldots \ldots \ldots \ldots \ldots \ldots \ldots \ldots \ldots \ldots \ldots \ldots 25$

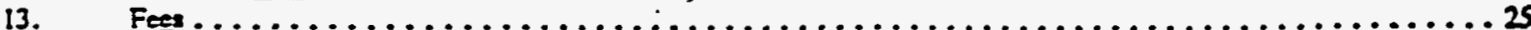

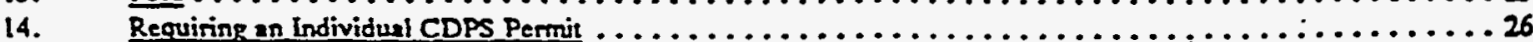

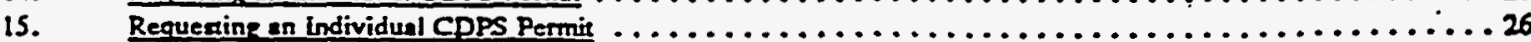

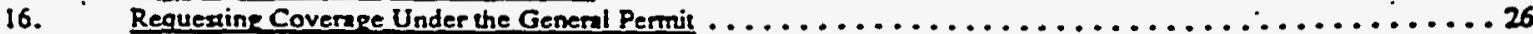




\section{PART I}

\section{A. COVERAGE UNDER THIS PERMIT}

\section{Types of Wastewater}

Under this general permit, facilities engaged in cleanup of gasoline from contaminated groundwater may be granted authorization to discharge treated process generated wastewaters into waters of the state of

Colorado. For purposes of this permit, process generated wastewaters inciude:

Wastewater produced from cleanup of groundwater contaminated by gasoline and aviation gasoline. Cleanup of other petroleum products, such as aviation turbine fuel, kerosene; and diesel fuel, may not be covered under this permit.

\section{Stream Dredging or Filling}

This permit does not constirute authorization under 33 U.S.C. 1344 (Section 404 of the Clean Water Act) of any stream dredging or filling operations.

\section{Criteria}

The following is a list of the criteria which will be used in evaluating whether or not an individual permit may be required instead of a general permit:

a) proximity of the operation to 2 landfill or mine and mill tailings;

b) evidence of significant noncompliance under a previous permit for the operation;

c) an effluent flow greater than 0.05 MGD (50,000 gpd), except for flow exemption under Part I.A.4;

d) presence of downstream driniking water intakes or a fishery;

e) the need to preserve high quality water;

f) addition of flocculants (settling ageats or chemical additives) to water prior to discharge;

g) use of chemicals (such as chlorine) within the system;

h) failure of the effluent to pass a Whole Efflueat Toxicity (WET) test;

i) - lead or organics levels in the efflueat which could lead to 2 violation of the receiving waters instream water quality standard for lead or organies, respectively;

j) an anti-degradation review by the Division showing that the discharge would cause unallowable degradation to the receiving waters. 


\section{A. COVERAGE UNDER THIS PERMIT}

\section{Flow Volume Exemption}

The Flow Volume Exemption may be applied under two separate circumstances, as follows:

a) The flow volume limit of 0.05 MGD may be temporarily waived for 30 days, for temporary dewatering sites. This provision will be approved by the Division on a case by case basis. The temporary dewatering projects which use the Flow Volume Exemption bave the option of remaining under the general permit beyond the initial period, provided that the 0.05 MGD flow limit is met afier the initial 30 days.

b) The flow voiume limit of 0.05 MGD may be temporarily deleted for groundwater remediation sites with a discharge of greater than 0.05 MGD, if approved by the Division, provided that the permittee has applied for an individual discharge permit for the site. During this interim period, the Division reserves the right to impose additional monitoring and/or other requirements in order to verify compliance with the geaeral permit. These requirements will be covered outside of the permit by letter. Noncompliance with the additional requirements could result in revocation of the permittee's certification under the general permit.

Any request for a Flow Volume Exemption must be inciuded with the permittee's permit application. See the individual Certification Rationale to determine whether or not the exemption is allowed. In any event, no temporary flow increase is allowed without prior Division approval.

The Division reserves the right to refuse a facility coverage under the exemption. The flow volume, level of · organies in the effivent, quality of receiving waters, and/or lack of information on the treatment system capability will be evaluated. The Division will use best professional judgment in determining whether or not the exemption will provide adequate coverage for the discharge.

\section{Application}

In order to be considered eligible for authorization to discharge under the terms and conditions of this permit, the owner, operator, and/or authorized agent of any facility desiring to discharge must submit, by certified mail or hand delivery, three copies of a completed discharge application form (available from the Division). The form requires, at 2 minimum, the following information:

a) Name, address, and descriptive location of the facility;

b) Name of principal in charge of operation of the facility;

c) Name of potential receiving waters;

d) Description of the type of activity resulting in the discharge, inciuding the anticipated duration of activity and/or the discharge, anticipated volume and rate of discharge, and the source of water which is to be discharged;

e) Description of any wastewater treatment system and recycle/reuse utilized; 
PART I

Page 5

Permir No. COG-310000

\section{A. COVERAGE UNDER THIS PERMIT}

5. Application cont.

f) A topographic map showing the general geographical location of the facility and any nearby landfills or mine or mill tailings;

g) A sketch of the facility showing all structures, outfalls and receiving waters, as well as storage locations of any petroleum or chemicais on site; and

h) A chemical analysis of the water to be discharged.

i) If the discharge is to 2 storm sewer system, ditch, or other man made conveyance, approval from the owner of the system must be obtained prior to certification under this permit. Documentation of this approval must be submitted with the discharge application.

At least thirty days prior to the anticipated date of discharge, three copies of the application shall be submitted to:

Colorado Deparment of Public Health and Environment

WQCD-PE-B2

4300 Cherry Creek Drive South

Denver, Colorado 80222-1530

The Division shall have up to thisty days after receipt of the above information to request additional data and/or deny the zuthorization for any particular discharge. Upon receipt of additional information. the Division shall have an additional thirty days to issue or deny authorization for the particular disebarge.

If the applicant does not receive $x$ request for additional information or a notification of denial from the Division within 30 days, authorization to discharge in accordance with the conditions of the permit shall be deemed granted.

If the Division determines that the operation does not fall under the authority of the general permit. then the information received will be treated as an individual permit. In this case, discharge is not allowed until a permit is issued, which may take 180 days.

\section{Expiration}

Authorization to diseharge under this general permit stall expire on Mareb 31, 2000. The Division must evaluate and may reissue this general permit once every five years, and must also recertify the applicant's authority to diseharge under the general permit at such time. Therefore, a permittee desiring continued coverzge under the general permit must reapply by September 30,1999. The Division will determine if the applicant may continue to operate under the terms of the general permit. An individual permit will be required for any facility not reauthorized to discharge under the reissued-general permit. For facilities wishing to terminate authorization under the new permit, provisions of Part II.B.S.d will be applicable. 


\section{B. TERMS AND CONDITIONS}

\section{General Limitations}

a) Discharge is allowed of treated process-generated wastewater from the cleanup of gasoline from contaminated groundwater. There shall be no discharge of groundiwater from the cleanup of any oithe petroleum products, such as aviation turbine fuel, kerosene, or diesel fuel without prior approval.

b) There shail be no discharge of sanitary wastewater from toilets or related facilities into the treatmeat facilities covered under this permit.

c) There sball be no discharge of floating solids or visible foam in other than trace amounts.

d) No cherricals are to be added to the discharge uniess permission for the use of a specifie chemial is granted by the Division. In granting the use of such chemicals, additional limitations and monitoring requirements may be imposed.

e) Bulk storage structures for gasoline and other chemicals shall have adequate protection 50 as to contain all spills and prevent any spilled material from entering the effluent stream or waters of the State.

\section{Effluent Limitations}

In sccordance with the Regulations for Water Quslity Control Commission for Efflueat Limitations, Section 10.1.3, and Regulations for the State Discharge Permit System, Section 6.9.2, 5 C.C.R. 1002-2, the permitted discharge shall not contrin efflueat parameter concentrations which exceed the following limitations or exceed the specified flow limitation:

\section{Effluent Parameter}

\footnotetext{
Flow, MGD

Total Suspeaded Solids, mg/l

Potentially Dissolved Lead, mgh *

Beazene, mg/l

Total BETX, mg/l **

Total Dissolved Solids, mg/ $/ * *$

Whole Efflueat Toxicity, Acute

Total Phosphores, mg/l ****
}

\section{Discharge Limitations}

\section{0-Day Avg 7-Day Avg Daily Max}

$\begin{array}{lll}\text { See B.2.2) } & \text { NA } & \text { Report } \\ 30 & 45 & \text { NA } \\ \text { NA } & \text { NA } & 0.031 \\ 0.001 & \text { NA } & \text { NA } \\ \text { NA } & \text { NA } & 0.1 \\ \text { NA } & \text { NA } & \text { Report } \\ \text { NA } & \text { NA } & \text { See B.2.c) } \\ \text { NA } & \text { NA } & \text { Report }\end{array}$

* The lead limit is applicable oniy to those facilities which discharge to streams which have an instrean lead limit, or which could impact such a stream. Se the individual Certification Rationale to determine if the limit is applicable.

* Total BTEX inciudes Benzene, Ethylbenzene, Toluene, and Total Xylenes.

*** Applicable to waters of the Colorado River basin oniy. See I.D.8.

***** Applicable to waters listed in I.C.4.b)

$\mathrm{pH}$ - standard units. sball remain between 6.5 and 9.0.

Oil and Grease shall not exceed $10 \mathrm{mg} / \mathrm{l}$. 
PART I

Page 7

Permit No. COG-310000

\section{B. TERMS AND CONDITIONS}

\section{Effluent Limitations (Cont.)}

a) The flow limit used will be the 30 day average flow (design) from the facility. See the individual Certification Rationale for the flow limit applieabie to the individual facility.

b) Benzene Best Professional Judgment is the basis for the benzene limitation in this permit. The Division has established the permit limit for benzene as $0.001 \mathrm{mg} /$, because this effluent concentration has been proven achievable using present technology, i.e. air stripping and/or granular activated carbon systems.

c) WET Testing: The Division will examine each diseharge application on a case by case basis. In cases where the date and circumstances justify, the Division may determine that WET testing not be required under the general permit for cerain Eacilities. Similariy, the Division may determine that the frequeacy of WET testing be either increased or decreased from the normal quareriy monitoring depending on the analytical data, duration of discharge, flow rates or other factors that the Division deems reiative. Unless specifically exempted in the rationaie, the following the following WET testing requirements shall be preformed.

As a condition of the permit, the permittee will be required to conduct routine monitoring for acute toxicity using Ceriodaphnia sp. (water flea) and fathead minnows. An acurte WET test is failed whenever the $\mathrm{LC}_{\text {so, }}$ which represents an estimate of the efflueat concentration which is lethal to $50 \%$ of the test organisms in the time period prescribed, is found to be less than or equal to $100 \%$ effluent.

The monitoring frequeacy for saute WET terts shall be querteriy, commencing with the first full calendar quarter following the permit effective date. Quarteriy test results shall be reported on a Quarteriy DMR along with the Discharge Monitoring Reports (DMRs) submitted for the end of the reporting calendar quarter (i.e., WET testing resuits for the celender quarter eading March 31 shall be reported with the DMR due April 28, with the remaining WET testing reports submitted with DMRs due each July 28 , October 28 and January 28 ).

In addition to the WET test reporing DMR, the permittee shall submit CDPS WET Test Report Forms (generally completed by the laboratory for each species). Copies of these reports are to be submitted to both the Division and EPA.

The permittee shall conduct each acute WET test in general wceordance with methods deseribed in Methods for Measuring the Acute Toxicity of Effiuents and Receiving Waters to Freshwater and Marine Organisms,EPA/600/4-90/027 or the most curreat edition, except as modified by the most . current Division guidance document entitled Guidelines for Conducting Whole Effluent-Toxicity Tests. The permittee shall conduct an acute 48-hour WET test using Ceriodaphnia sp., and an acute 96-hour WET test using fathead minnows. Acute tests will be replacement static tests of a single grab sample.

Should seute toxicity be detected, the permittee must provide written notification of the failure of a WET test to the Division, along with a statement as to whether the Preliminary Toxicity Incident ("PI")/Toxicity Identification Evaluation ("TIE") investigation or accelerated testing is being performed. Notification must be received by the Division within 14 calendar days of the demonstration of acute WET in the routine required test. "Demonstration" means no later thas the last day of the laboratory test. 


\section{B. TERMS AND CONDITIONS}

\section{Effluent Limitations}

c) WET Testing cont.

If a routine scute WET test is failed, the permittee stall either:

(i) proceed to conduct the PTI/TIE investigation as described below or

(ii) conduct accelerated testing using the single species found to be more sensitive.

If accelerated testing is being periormed, the permitte shall provide written natification of the results within 14 calendar days of completion of the "Pattern of Toxicity"/"No Toxicity" demonstration. Testing will be at lesst once every two weeks for up to five tests until 1) two consecutive tests fail or three of five rests fail, in which case 2 pattern of toxicity has beed demonstrated or, 2) two consecutive tests pass or three of five tests pass, in which cese no pettern of woxicity hes been found. If no pattern of toxicity is found, the toxicity episode is considered to be ended and rautine testing is to resume. If a pattern of toxicity is found, a PII/TIE investigation is to be performed. If a pattern of toxicity is not demonstrated but a significant level of erratic toxicity is found, the Division may require an increased frequency of routine monitoring or some other modified approzeh.

The results of the PTI/TIE investigation are to be receired by the Division within 120 days of the demonstration of acute WET in the routine test, as defined above, or if accelerated testing is periormed, the date the pattern of toxicity is demonstrated. A status report is to be provided to the Division at the 30,60 and 90 day points of the PTI/TIE inrestigation. The Division may extend the time frame for investigation where reasonable justification exists: A request for an extension must be made in writing and received prior to the 120 day deadline. Such request must include $a$ justification and supporting dats for such an extension.

The permittee may use the time for investigation to conduct 2 PTI or move directly into the TIE. A PII consists of a brief search for possibie sources of WET, which might reveal causes of such toxicity and appropriate corrective sctions more simply and cost effectively than a formal IIE. If the PII allows resolution of the WET incident, the TIE need not necessarily be conducted. If, however, WET is not ideatified or resolved during the PTI, the TIE must be conducted within the 120 days.

Any permittee that is required to conduct a PII/TIE investigation sball do 50 in conformance with procedures ideatified in the following documents, or as subsequeatly updatod: 1) Methods for Aquatic Toxicity.Identification Evaluations, Phase I Toxicity Characterization Procodures, EPA/600/691/003 Feb. 1991 and 2) Methods for Aquatic Toxicity Identification Evaluations, Phase II Toxicity Identification Procedures, EPA/600/3-88/035 Feb. 1989. A third document in this series is Methods for Aquatic Toxicity Identification Evaluations, Phase IIT Toxicity Confimation Procedures. EPA/600/3-88/036 Feb. 1989. As indicated by the title, this procedure is intended to confirm that the suspected toxicant is truly the toxicant. The Phase III investigation is optional. 
Permit No. COG-310000

\section{B. TERMS AND CONDITIONS}

2. Effuent Limitations

c) WET Testing cont.

If toxicity spontaneousily disappears at any time after a test failure, the perwittee shall notify the Division in writing within 14 days of a demonstration of disappearence of the toxicity. If a pattern of toxicity or recurring toxicity is not identified, the toxicity ineident response is considered closed and normal WET testing shall resume.

\section{MONITORING REQUTREMENTS}

\section{Frequency and Sample Type}

In order to obtain an indication of the probable compliance or noncompliance with the effluent limitations specified in Section B, the permittee shall monitor all effluent parameters at the following frequencies.

\section{Effluent Parameter $\quad$ Measurement Frequency Sampie Type}

Flow, MGD

Total Suspended Solids, mg/l

pH, s.u.

Oil and Grease, mg/l

Potentially Dissolved Lead, mg/l

Beazeae, mg/l

Total BETX, mg $/$

Whole Effluent Toxicity, Acule

(See Part I.B.2.c)

Total Dissolved Solids, mg $\Lambda$."

Total Phosphorus, mg/l **

$\begin{array}{lc}\text { Weekly } & \text { Instantaneous or Continuous } \\ \text { Monthly } & \text { Grab } \\ \text { Weekly } & \text { Grab } \\ \text { Weekly } & \text { Visual See I.D.12. } \\ \text { Monthly } & \text { Grab } \\ \text { Monthly } & \text { Grab } \\ \text { Monthly } & \text { Grab } \\ & \\ \text { Quarterly *** } & \text { Grab } \\ \text { Quartedy } & \text { Grab } \\ \text { Monthly } & \text { Grab }\end{array}$

- Applicable to waters of the Colorado River basin only. See I.D.8.

** Applicable to waters listed in I.C.4.b)

*** Quarterly moaitoring uniess modified by the Division.

If the permittec. using the approved analytical methods, monitors any parameter more frequently than required by this permit, then the resuits of such monitoring shall be included in the calculation and reporting of the values required in the Discharge Monitoring Report Form or other forms as required by the Division. Such increased frequeacy shail also be indicated. 


\section{MONITORING REQUIREMENTS cont.}

\section{Detoction Limits}

When the most seasitive anzlytical method which complies with Part I.F.2. of the permit has a detection limit greater than or equal to the permit limih, the permittee sholl report "less than the detectable limit," as appropriate. Such reports shall not be considered as violations of the permit limit.

\section{Reporting of Data}

Reporting of the data gathered in compliance with Part I.C.I shall be on a quarterly basis. Monitoring results shall be summarized for each month and reported on Division approved discharge monitoring report forms received by the Division no later than the 28 th day of the last month of the quarter. If no discharge occurs during the reporting period, "No Discharge" shall be reported.

Duplicate signed copies of the above report forms shall be submitted to the following addresses:

Submit the top copy (original) of each set of forms to:

Colorado Department of Public Health and Environment WQCD-PE-B2

4300 Cherry Creek Drive South

Deaver, Colorado 80222-1530

Submit the second duplicate of each set of forms to:

U.S. Environmeatal Protection Ageacy

Water Maragement Division

NPDES Branch 8WM-C

Deaver Place

99918 th Street, Suite 500

Denver, CO 80202-2405

\section{Special Monitoring}

Pursuzat to CRS 1973, 25-8-304, and to maintain a current datz base for proper evaluation of the water quality impret of the discharge, the permittee shall moxitor and submit data for Organic Toxic Pollueants in the vointile fraction listed in I.C.4.e) on an annual basis. The anelysis shall be done from a grab sample by GCMS and each parameter shall be reported individually. The first instance of monitoring stall be performed within three months of the certification effective date, and the results submitted to the Division with the next DMR.

If the new data indicate the presence of any organics at levels which might violate the orgzaic pollutant standards contained in tables A, B or C of "The Basic Standards and Methodologies for Surface Water," 3.1.0, the Division reserves the right to require the. facility to obtain an individual permit. 
PART I

Page 11

Permit No. COG-310000

\section{C.- MONITORING REQUIREMENTŚ}

\section{Special Monitoring (Cont.)}

a) Organic Toxic Pollutants - Volatiles Fraction

- (all units are ug/l)

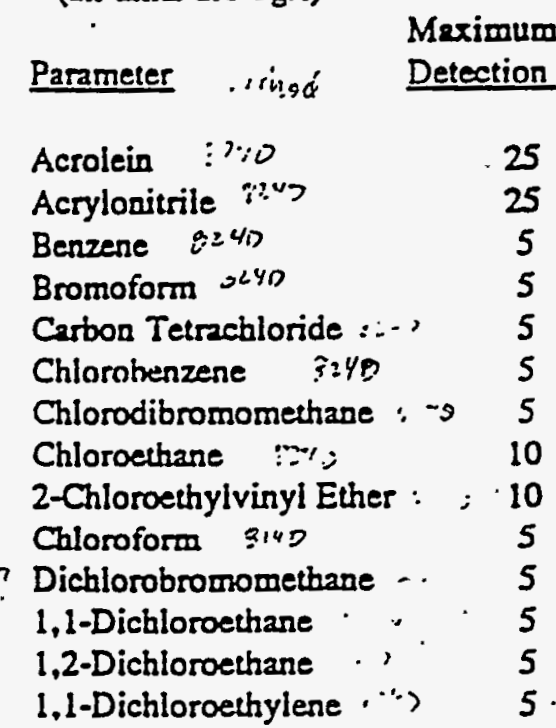

Parameter

\section{1,2-Dichloropropane}

1,3-Dichloropropylene

Ethylbeazene

Methyl Bromide

Methyl Chloride

Methylene Chioride

1,1,2,2-Tetractloroethane

Tetracbloroethyleae

Toluene

1,2-Traas-dicbloroethylene

1,1.1-Trichloroethane

1,1,2-Trichloroethane.

Trichloroethylene

Vinyl Chloride
Maximum Acceptzble Detection Level

$$
\begin{aligned}
& 5 \text { \&ष० } \\
& 5 \text { \%iष. } \\
& 5 \text { PLt } \\
& 10 \text { 8iv } \\
& 108240 \\
& 10 \text { ミ《ए } \\
& 5 \% . . .) \\
& 5 \text { :b:? } \\
& 5 \text { 6. } \\
& 58240 \\
& 55=10 \\
& 58-40 \\
& 52 \% \\
& 2 \text { r: }
\end{aligned}
$$

b) Total phosphorus (as P) monitoring is required for facilities which diseharge into the following drainage basins: Caerry Creek basia. Chatfieid Reservoir upstream of the USGS gage at Waterton and on Plum Creek, Dillon Reservoir basin (i.e. Tea Mile Creek, Snake River, Blue River, all tributaries to the Dillon Reservoir), and Bear Creek basin. The Division also reserves the right to include phosphorus monitoring for any receiving waters that may later enter into phosphorus monitoring requirements. If phosphorus monitoring is 2 requirement of the permit than it stall be inciuded within the terms and conditions of the individual Certification Rationale of the permit. Additional monitoring for phosphonis shall be included on the (DMR) and shall be subject to the permit's monitoring and reporting requirements. Phosphorus sampling shall be on 2 quarterty basis, taken as a grab sample. 


\section{DEFINITIONS}

1. "BETX" shall be measured as the sum of beazene, echylbenzene, toluene and xylenes. EPA methods 502. $602,624,1624,8020,8240$, or 8260 shall be used for the measurement of benzene. ethylbenzene. toluene, and xylenes mcluding ortho-, meta-, and para-xylene.

2. A "composite" sample, for monitoring requirements, is 2 minimum of four (4) grab samples collected at equally spaced swo (2) hour intervals and proporioned according to flow.

3. A "continuous" measurement, for flow monitoring requirements, is a measurement obtained from an automatic recording device which continually measures flow.

4. A "grab" sample, for monitoring requirements, is a single "dip and take" sample.

5. An "instantaneous" measurement, for monitoring requirements, is a singie reading, observation, or measurement periormed on site.

6. The "potentially dissolved metal" fraction is defined in "The Basic Standards and Methodologies for Surface Water," 3.1.0, as that portion of a constinent measured from the filtrate of a water and suspended sediment sample, that was first treated with aitric acid to a pH of 2 or less and let stand for 8 to 96 hours prior to sample filtration using a 0.4 or 0.45 -um membrane filter. Note the "potentially dissolved" method cannot be used where nitric acid will interfere with the arialytical procedure used for the constitueat measured.

7. A "quarterly sampie" shall be collected during March, June, September and December, if a continual discharge oceurs. If the discharge is intermittent, thea samples shall be collected during the period that discharge occurs.

8. "Salinity" is measured as Total Dissolved Solids (TDS). Where based on a minimum of 5 samples, the permittee demronstrates, to the satisfaction of the Water Quality Control Division, that the level of TDS in the effiuent can be calculated based upon the level of electrical conductivity, the permittee may measure and report salinity in terms of electrical conductivity.

9. The "seven ( $(7)$ day average" shall be determined by the arithmetic mean of all samples taken in a seven (7) day period. Samples may not be used for more than one (1) reporting period.

10. A "24 hour composite" sample is a combination of at least eight (8) sample aliquots of at least 100 milliliters. collected at equally spaced intervals during the operating hours of a facility over a tweaty-four (24) hour period. For volatile pollutants, aliquots wust be combined in the laboratory immediately before analysis. The composite must be flow proporional: either the time interval between each aliquot or the volume of each aliquot must be proportional to either the wastewater or effluent flow at the time of sampling or the total wastewater or effiuent flow since the collection of the previous aliquot. Aliquots may be collected manually or automatically. 
D. DEFINITIONS cont.

11. "The thirny (30) day average" shall be determined by the arithmetic mean of all samples collected during a thirty (30) consecutive-day period or calendar month.

12. A. "visual" observation, for oil and grease monitoring requirements, is defined as observing the discharge to check for the presence of a visible sheen or floating oil. If either of these is preseat, a grab sample shall be taken, analyzed, and reported on the appropiziate DMR. In addition, corrective action shall be taken imarediately to mitigate the discharge of oil and grease. A description of the corrective action taken should be included with the DMR.

13. "Water Quality Control Division" or "Division" means the state Water Quality Control Division as established in 25-8-101 et al.)

\section{E. REPORTING}

\section{Signatory Requirements}

All reports and other information required by the Division shall be signed in ink and certified for accuracy by the permittee in accord with the following criteria:

a) In the case of comporations, by a principal executive officer of at least the level of vice-president or his or her duly authorized representative, if such representative is responsible for the overall operation of the facility from which the discharge deseribed in the form originates:

b) In the case of a parmership, by a general partoer.

c) In the case of a sole proprietorship, by the proprietor;

d) In the case of a municipal, state, or other public facility, by eitber a principal executive officer, ranking elected official, or other duly authorized employee.

e) The permittoe shall make the following certification on all such documents;

-I cerrify under peaalty of law that this document and all attachments were prepared under my direction or supervision in accorcance with a system designed to assure that qualified personnel properiy gather and evaluate the information suburitted. Based on my inquiry of the person or persons who manage the system. or those persons directly responsible for gathering, the information submitted is, to the best of my knowiedge and belief, true, accurate, and complete. I am aware that there are significant penalties for submitting false information, inciuding the possibility of fine and imprisonment for knowing violations."

\section{F. GENERAL REQUIREMENTS}

\section{Representative Sampling}

Samples and measurements taken as required herein shall be representative of the volume and nature of the monitored discharge. All samples shall be taken at the monitoring points specified in this permit and. unless otherwise specified, before the effluent joins or is diluted by any other wastestream, body of water, or substance. Monitoring points shall not be changed without notification to and approval by the Division. 
F. GENERAL REQUIREMENTS cont.

2. Analvitical and Sampling Methods for Monitoring

Analytical and sampling methods utilized by the discharger shall conform to Colorado Regulations for Effluent Limitations (10.1.5), and to regulations published pursuant to Section 304 (h) of the Clean Water Act.

The analytical method selocted for a parameler stall be the one tbat can measure the lowest detected limit for that parameter unless the permit limitation or stream standard for those parameters is within the testing range of another approved method.

3. Records

The permittee shall establish and maintain records. Those records shall inciude the following:

a) The date, type, exact location, and sime of sampling or measurements;

b) The individual(s) who performed the sampling or measurements:

c) The date(s) the analyses were performed;

d) The individual(s) who performed the anslyses;

e) The analytical techriques or methods used:

f) The results of such analyses; and

g) Any other observations which may result in an impact on the quality or quantity of the discharge as indicated in 40 CFR 122.44 (i)(1)(iii).

The permittee shall retain for a minimum of three (3) years records of all monitoring information, including all original strip char recordings for continuous monitoring instrumentation, all calibration and maintenance records, copies of all reports required by this permit and records of all data used to complete the application for coverage under this permit. This period of retention shall be extended during the course of any unresolved litigation regarding the discharge of pollutants by the permittee or when requested by the Division or Regional Administrator of EPA. .

\section{Flow Measuring Device}

If not already a pars of the permitted facility, within ninety (90) days after the effective date of the cerification, a flow measurang device shall be installed to give representative values of efflueat quantities at the respective discharge points. A flow measuring device will be applicable at all designated discharge points. Pump capacity may be used for flow measurement if corrected for elevation bead, pipe size and length, and pipe friction loss.

At the request of the Water Quality Control Division, or the Environmental Protection Agency, the permittee shall show proof of the accuracy of any flow measuring device used in obtaining data submirted in the monitoring reporr. The flow-measuring device must indicate values within ten (10) percent of the actual flow being discharged from the facility. 
PART I

Page 15

Permit No. COG-310000

\section{F. GENERAL REQUIREMENTS cont.}

\section{Best Management Practices}

The permittee shall implement and maintain Best Management Practices for the control of surface nunoff and prevention of erosion due to the discharge. Best Management Practices can include various options. such 2s: modification of the pipe discharge strueture to disperse flows; containment of water by hay bales or other comparable structures; the use of geocloth, filter fabric, or plastic sheeting for protection of containment structures; rip-rap; and/or any other approved methods which might be used.

There shall be no sludge banks or deposition of solids dowastream from the discharge(s). Control of excessive suspeaded solids shall be undiertaken as recessary to prevent reaching surface receiving waters and causing any receiving water deterioration. Any bazardous materials or chemicals stored or used on site shall be adequately handled and contained to prevent any spills from occurring. Earthen dikes or concrete basins with capacity to hoid contents of storage tanks or containers shall be used to prevent spills of these materials into State Waters in the event of failure of the storage containers. 
Page 16

Permit No. COG-310000

\section{PART II}

\section{A. MANAGEMENT REQUTREMENTS}

\section{Change in Discharge}

The permittee shall inform the Division (Permits and Enforcement Section) in writing of any intent to construct, install, or ziter any process, facility, or zetivity that is likely to result in 2 new or altered discharge, in and shall furnish the Division such plans and specifications which the Division deems reasonably necessary to evaluate the effect on the discharge and receiving stream.'

The permittee shall submit this notice within two (2) weeks after making a determination to perform the type of activity referred to in the preceding paragraph. Process modifications inciude, but are not limited to, the introduction of any new pollutant not previously identified in the permit, or any other modifications which may result in a discharge of a quantity or quality different from that which was evaluated in the drafting of the permit including subsequent ameadments. Following such notice, the permittee sball be required to submit a new CDPS application, and may be required to be covered under an individual permit to specify and limit any poliutants not previously limited, if the new or altered discharge might be inconsistent with the conditions of the general permit. In no case shall the permittee implemeat such change without first notifying the Division.

2. Special Notifications - Definitions

a) Bypass: The inteational diversion of waste streams from any portion of a treatrment facility.

b) Severe Property Damage: Substantial physical damage to property at the treatmeat facilities which causes them to become inoperable, or substantial and permanent loss of natural resources which can reasonably be expected to occur in the absence of 2 bypass. It does not mean economic loss calused by delays in production.

c) Spill: An unintentional release of solid or liquid material which may cause pollution of state waters.

d) Upset: An exceptional incident in which there is uninteational and temporary noncompliance with permit efflueat limitations because of factors beyond the reasonable control of the permittec. An upset does not include noncompliance to the extent caused by operational error, improperiy designed treatmeat facilities, inadequate treatment facilities, lack of preventative maintenance, or careless or improper operation.

3. Noncompliance Notification

a) If, for any reason, the permittee does not comply with or will be unable to comply with any discharge limitations or standards specified in this permit, the permittee shall, at a minimum, provide the Water. Quality Control Division and EPA with the following information:

A description of the discharge and cause of noncompliance; 


\section{A. MANAGEMENT REQUIREMENTS}

3. Noncompliance Notification cont.

(ii) The period of noncompliance, including exact dates and times and/or the anticipated time when the discharge will retum to compliance; and

(iii) Steps being taken to reduce, eliminste, and prevent recurrence of the noncompiying discharge.

b) The permittee shall repor the following instapces of noncompliance orally within twenty-four (24) hours from the time the permittee becomes aware of the noncompliance, and shall mail to the Division a written report containing the information requested in Part Il.A.3.(a) within five (5) days after becoming aware of the noncompliance:

(i) Any instance of noncompliance which may endanger health or the environment;

(ii) Any unanticipated bypass which exceeds effiuent limitations:

(iii) Any upset which causes an exceodance of any effluent limitation in the permit:

(iv). Any spill which causes any effluent limitation to be violated;

(v) Daily maximum violations for any toxic pollutants or hazardous substances limited by Part I-A of this permit and specified as requiring 24 hour notification. This includes any toxic polluttant or hazardous substance or any poilutant specifically identified as the method to control any toxic pollutant or hazardous substance.

c) The permittee shall report all other instances of non-compliance not requiring 24-bour notification at the time Discharge Monitoring Reports are submitted. The reports shail contain the information listed in sub-paragraph (a) of this section.

\section{Submission of Incorrect or Incomplete information}

Where the permittee failed to submit any relevant facts in a permit application, or submitted incorrect information in a permit application or report to the Division, the permittee shall promptly submit the relevant application information which was not submitted or any additional information needed to correct any erroneous information previously submitted.

\section{Bypass}

The permitte may allow any bypass to occur which does not cause effluent limitations to be exceeded, but if and only if it is for essential maintenance to assure optimal operation. These bypasses are not subject to the provisions noted-in item b.) below. Division notification is not required.

Bypass is prohibited, and the Division may take enforcement action against a permittee for bypass, unless:

a) Bypass was unavoidable to prevent loss of life, personal injury, or severe property damage; 


\section{A. MANAGEMENT REQUIREMENTS}

5. Bvpass cont.

b) There were no feasible alteratives to the bypass, such as the use of auxiliary treatment facilities, retention of untreated wastes, or maintensance during normal periods of equipment downtime. This condition is not satisfied if the permittee could have installed adequate backup equipmeat to prevent a bypass which occurred during nomal periods of equipmeat downime or preventative maintenance;

c) The permittee submitted notices as required in "Bypass Notification", Part II.A.6.

\section{Bypass Notification}

If the permitree knows in advance of the aeed for a bypass, a notice shall be submitted, at least tea days before the date of the bypass, to the Division and the Environmental Protection Agency.(EPA). The bypass shall be subject to Division approval and limitations imposed by the Division and EPA.

7. Upsets

\section{a) Effect of an Upset}

An upset constitutes an affirmative defense to an action brought for noncompliance with permit efflueat limitations if the requirements of paragraph $b$ of this section are met. (No determination made during administrative review of claims that noncompliance was caused by upset, and before an action for noncompliance, is final administrative action subject to judicial review.)

\section{b) Conditions Necessary for a Demonstration of Upset}

A permittee who wishes to establish the effirmative defense of upset shall demonstrate through properiy signed contemporaneous operating logs, or other relevant evidence that:

(i) An upset oceurred and that the permittee can identify the specific cause(s) of the upset; and

(ii) The permitted facility was at the time being properly operated and maintained: and

(iii) The permittee submitted notice of the upset as required in Part Il.A.3. of this permit (24-hour notice); and

(iv) The permittee shall take all reasonable steps to minimize or prevent any discharge or sludge use or disposal in violation of this permit which bas a reasonable likelihood of adversely affecting buman health or the eavironment.

(v) In addition to the demonstration required above, a permittee who wishes to establish the affirmative defence of upser for a violation of effluent limitations based on water quality standards shall also demonstrate through monitoring, modeling, or other methods that the relevant standards were achieved in the receiving water. 
PART II

Page 19

Permit No. COG-310000

\section{A. MANAGEMENT REQUIREMENTS}

7. Upsets cont.

\section{c) Burden of Proof}

In any enforcement proceeding the permittee seeking to establish the occurrence of an upset has the burdea of proof.

\section{Removed Substances}

Solids, sludges, or other pollutants removed in the course of treatment or control of wastewaters shall be properly disposed of in a manner such as to prevent any pollutant from such materials from entering waters of the State.

\section{Minimization of Adverse Impact}

The permittee shall take all reasonable steps to minimize or prevent any adverse impact to waters of the State resulting from any discharge. As necessary, accelerated or additional monitoring to determine the nature and impact of the noncomplying discharge is required.

10. Discharge Point

Any discharge to the waters of the State from a point source other than specifically authorized by this permit is prohibited.

\section{Reduction, Loss, or Failure of Treatment Facility}

The permittee has the duty to halt or reduce any activity if necessary to maintain compliance with the efflueat limitations of the permit. Upon reduction, loss, or failure of the-treatment facility, the permittee shall, to the extent necessary to maintain compliance with its permit, control production, or all discharges, or both until the facility is restored or an altemative method of treatmeat is provided. This provision for example, applies to power failures, uniess an alternative power source sufficieat to operate the wastewater control facilities is provided.

It shall not be a defease for a permittee in an enforcement action that it would be necessary to halt or reduce the permitted activity in order to maintain compliance with the conditions of this permit.

12. Proper Operation and Maintenance

The permittee shall at all times properly operate and maintain all facilities and systems of treatmeat and control (and related appurenances) which are installed or used by the permittee as necessary to achieve compliance with the conditions of this permit. Proper operation and maintenance includes effective performance, adequate funding, adequate operator staffing and training, and adequate laboratory and process controls, inciuding appropriate quality assurance procedures. This provision requires the operation of backup or auxiliary facilities or similar systems which are installed by the permittee only when necessary to achieve compliance with the conditions of the permit. 
PART II

Page 20

Permit No. COG-310000

B. RESPONSIBILITIES

\section{Inspections and Right to Entry}

The permittee shall allow access to the Director of the Division, the EPA Regional Administrator, 2nd/or their suthorized representative, upon the presentation of credentials. In the making of such inspections, investigations, and determinations, the Division, in.sofar 25 practicable, may designate as its authorized representatives any qualified personnel of the Department of Agriculture. The Division may also request assistance from any other state or local agency or institution.

a) To enter upon the permittee's premises where 2 regulated facility or activity is located or in which any records are required to be kept under the terms and conditions of this permit:

b) At reasonable times to have access to and copy any records required to be kept under the terms and conditions of this permit and to inspect any monitoring equipment or monitoring method required in the permut; and

c) To enter upon the permittee's premises to investigate, within reason, any actual, suspected,.or potential source of water pollution, or any violation of the Colorado Water Quality Control Act. The investigation may include, but is not limited to, the following: sampiing of any discharge and/or process waters, the taking of photographs, interviewing permittee staff on alleged violations, and access to any and all facilities or areas within the permittee's premises that may have any effect on the diseharge, permit, or alleged violation. Such entry is also authorized for the purpose of inspecting and copying records required to be kept coneerning any effluent source.

d) The Division shall split any sampie taken with the permittee if requested to do so by the permittee.

2. Dutv to Provide Information

The permittee shall fumish to the Division, within a reasonable time, any information which the Division may request to determine whether cause exists for modifying, revoking and reissuing, or terminating coverage under. this permit, or to determine compliance with this permit. The permittee shall also furnish to the Division, upon request, copies of records required to be kept by this permit.

3. Iransfer of Ounership or Control

Certification under this permit may be transferted to a new permittee if:

a) The current permittee notifies the Division in writing 30 days in advance of the proposed transfer date; and

b) The notice includes a written agreement between the existing and new permittes containing a specific date for transfer of permit responsibility, coverage and liability between them; and

c) The Division does not notify the existing permittee and the proposed aew permittee of its inteat to modify, or revoke and reissue the permit; and

d) The current permittee has met all fee requirements of the Reguiations for the State Discharge Permit System. Section 6.16.0. 
B. RESPONSIBILITIES cont.

\section{Availability of Repors}

Except for data determined to be confidential under Section 308 of the Federal Clean Water Act and Reguiations for the State Discharge Permit System 6.6.4 (2), all reports prepared in accordance with the terms of this permit shail be available for public inspection at the offices of the Division and the Environmental Protection Agency.

\section{Modification, Suspension, or Revocation of Permits Bv the Division}

All permit modification, termination or revocation and reissuance actions shall be subject to therequirements of the Regulations for the State Discharge Permit System, Sections 6.6.2. 6.6.3, 6.8.0 and 6.16.0, 5 C.C.R. 1002-2, except for minor modifications. Minor modifications may oniy correct typographical errors, require a change in the frequency of monitoring or reporting by the permittee. change an interim date in a schedule of compliance or allow for a change in ownership or operational control of a facility including addition, deactivation or relocation of discharge points where the Division determines that no other change in the permit is necessary.

a) This permit, and certification under this permit, may be modified, suspended, or revoked in whole or in pan during its term for reasons determined by the Division including but not limited to, the following:

(i) Violation of ariy terms or conditions of the permiti :

(ii) Obtaining a permit by misrepresentation or failing to diselose any fact which is material to the granting or denial of a permit or to the establishment of terms or conditions of the permit;

(iii) Materially false or inaccurate statements or information in the application for the permit. or;

(iv) A determination that the permitted activity endangers human health or the classified or existing uses of State Waters and can only be regulated to acceptable levels by permit modifications or termination.

b) This permit. or certification under this permit, may be modified in whole or in part due to a change in any condition that requires either a temporary or permanent reduction or elimination of the permitted discharge, such as:

(i) There are material and substantial alterations or additions to the permitted facility or activity which occurred after permit issuance which justify the application of permit conditions that are different or absent in the existing permit; 
PART II

Page 22

Permir No. COG-310000

\section{B. RESPONSIBILITIES}

\section{Modification, Suspension, or Revocation of Permits Bv the Division cont.}

b)

(ii) The Division has received new information winch was not available at the time of permit issuance (other thari revised regulations, guidance, or test methods) and which would bave justified the application of different permit conditions at the time of issuance. For permits issued to new sources or new dischargers, this cause includes information derived from effluent testing required under Section 6.5.7(5) of the Regulations for the State Discharge Pemit System. This provision allows a modification of the permit to inciude conditions that are less stringent than the existing permit only to the extent allowed under Section 6.11.0 of the Regulations for the State Discharge Permit System:

(iii) The standards or regulations on which the permit was based have been changed by promulgation of amended standards or regulations or by judicial decision after the permit was issued. Permits may be modified during their terms for this cause oniy as follows:

(a) The permit condition requested to be modified was based on a promulgated effluent limitation guideline, EPA approved water quality standard, or an effluent limitation set forth in 5 CCR 1002-3, $\$ 10.1 .0$ et seq.; and

(b) EPA has revised, withdrawn; or modified that portion of the regulation or efflueat limitation guideline on which the permit condition was based, or has approved a Commission action with respect to the water quality standard or effluent limitation on which the permit condition was based; and

(c) The permittee requests modification after the notice of final action by which the EPA effluent limitation guideline, water quality standard, or effluent limitation is revised, withdrawn, or modified; or

(d) For judicial decisions, a court of competent jurisdiction has remanded and stayed EPA promulgated regulations or effluent limitation guidelines, if the remand and stay concern that portion of the regulations or guidelines on which the permit condition was based and a request is filed by the permittee in accordance with this Regulation, within ninety (90) days of judicial remand;

(iv) The Division determines that good cause exists to modify a permit condition because of events over which the permittee has no control and for which there is no reasonable available remedy:

(v) The permittee has received a variance;

(vi) When required to incorporate applicable toxic effluent limitation or standards adopted pursuant to $\S 307(a)$ of the Federal act;

(vii) When required by the reopener conditions in the permit; 


\section{B. RESPONSIBILITIES}

5. Modification, Suspension, or Revocation of Permits By the Division cont.

b) .

(viii) As necessary under 40 C.F.R. 403.8(e), to inciude a compliance schedule for the development of a pretreatment program:

(ix) When the level of discharge of any pollutant which is not limited in the perrait exceeds the level which can be achieved by the technology-based treatmeat requirements appropriate to the permittee under Section 6.9.2(1) of the Regulations for the State Discharge Permit System;

(x) To establish a pollutant notification level required in Section 6.9 .5 of the Regulations for the State Discharge Permi System:

(xi) To correct technical mistakes, such as errors in calculation, or mistaken interpretations of law made in deternining permit conditions, to the extent allowed in Section 6.11 .0 of the Regulations for the State Discharge Permit System, or,

(xii) When required by a permit condition to incorporate a land application plan for beneficial reuse of sewage sludge, to revise an existing land application plan, or to add a land application pian.

(xiii) For any other cause provided in Section 6.11.0 of the Regulationis for the Stase Discharge Permis System.

c) At the request of a permittee, the Division may modify or terminate a permit and issue a new permit if the following conditions are met:

(i) The Regional Administrator has been notified of the proposed modification or termination and does not object in writing within thirty $(30)$ days of receipt of notification:

(ii) The Division finds that the permittee has shown reasonable grounds consistent with the Federal and State statutes and regulations for such modifications or termination;

(iii) Requirements of Section 6.16 .0 of the Regulations for the State Discharge Permit System have been met, and;

(iv) Requirements of public notice have been met.

d) - Permit modification (except for minor modifications), termination or revocation and reissuance actions sball be subject to the requirements of Sections 6.6.2, 6.6.3, 6.7.0, 6.8.0 and 6.16.0 of the Regulations for the State Discharge Permit System. The Division shall act on a permit madification request, other than minor modifications requests, within 180 days of receipt thereof. Except for minor modifications. the terms of the existing permit govem and are enforceable until the newly issued permit is formally modified or revoked and reissued following public.notice. 


\section{B. RESPONSIBILITIES}

5. Modification, Suspension, or Revocation of Permits By the Division cont.

e) Upon conseat by the permittee, the Division may make minor permit modifications without following the requirements of Sections 6.6.2, 6.6.3,6.8.0, and 6.16.0 of the Regulations for the State Discharge Permit System. Minor modifications to permits are limited to:

(i) Correcting typographical errors; or

(ii) Increasing the frequency of monitoring or reporting by the permittee; or

(iii) Changing an interim date in a schedule of compliance, provided the new date of compliance. is not more than 120 days after the date specific in the existing permit and does not interfere with attainment of the final compliance date requirement; or

(iv) Allowing for a transfer in ownership or operational control of a facility where the Division determines that no other change in the permit is necessary, provided that a written agroemeat containing a speciñe date for transfer of permit responsibility, coverage and liability between the current and new permittees has been submitted to the Division; or

(v) Changing the construction schedule for a discharger which is a new source, but no such cbange shall affect a discharger's obligation to have all pollution control equipment installed and in operation prior to discharge; or

(vi) Deleting a point source outfall when the discharge from that outfall is terminated and does not result in discharge of pollutants from other outfalls except in accordance with permit limits; or

f) When a permit is modified, only the conditions subject to modification are reopened. If a permit is revoked and reissued, the entire permit is reopened and subject to revision and the permit is reissued for a new term.

g) The filing of a request by the permittee for a permit modification, revocation and reissuance or termination does not stay any permit condition.

6. Oil and Hazardous Substance Liability

Nothing in this permit shall be construed to preclude the institution of any legal action or relieve the permittce from any responsibilities, liabilities, or penalties to which the permittee is or may be subject to under Section 311 (Oil and Hazardous Substance Liability) of the Clean Water Act.

\section{State Laws}

Nothing in this permit shall be construed to preciude the institution of any legal action or relieve the permittee from any responsibilities, liabilities, or peaalties established purstant to any applicable State law or regulation under authority granted by Section 510 of the Clean Water Act. 
PART 11

Page 25

Permit No. COG-310000

B. RESPONSIBILITIES cont.

\section{Permit Violations}

Failure to comply with any terms and/or conditions of this permit shall be a violation of this permit.

\section{Propernv Rights}

The issuance of this permit does not convey any property or water rights in either real or personal property, or stream flows, or any exclusive privileges, nor does it authorize any injury to private property or any invasion of personal rights, nor any infringement of Federal, State or loeal laws or regulations.

10. Severability

The provisions of this permit are severable. If any provisions of this permit, or the application of any provision of this permit to any circumstance, is held invalid, the application of such provision to other circumstances and the application of the remainder of this permit shall not be affected.

\section{Renewal Application}

If the permittee desires to continue to discharge, a permit renewal application shall be submitted at least one hundred eighty (180) days before this permit expires. If the permittee anticipates there will be no discharge after the expiration date of this permit, the Division should be promptly notified so that it can terminate the cerrification in accordance with Part II.B.5.

\section{Confidentiality}

Any information relating to any secret process, method of manufacture or production, or sales or marketing data which has been declared confidential by the permittee, and which may be acquired, ascerained, or discovered, whether in any sampling investigation, emergency investigation, or otherwise. shall not be publicly disclosed by any member, officer, or employee of the Commission or the Division. but shall be kept confidential. Any person seeking to invoke the protection of this Subsection (2) shall bear the burden of proving its applicability. This section shall never be interpreted as preventing full disclosure of effluent dati.

13. Fees

The permittee is required to submit payment of an annual fee as set forth in the 1983 amendments to the Water Quality Control Act. Section 25-8-502 (1) (b), and State Discharge Permit Regulations 5CCR 1002-2. Section 6.16.0 as amended. Failure to submit the required fee when due and payable is 2 violation of the permit and will result in enforcement action pursuant to Section 25-8-60l et. seq., C.R.S. 197325 amended. 
PART II

Page 26

Permost No. COG-310000

\section{B. RESPONSIBILITIES cont.}

14. Reguiring an Individual CDPS Permit

The Director may require any owner or operator covered under this permit to apply for and obtain an individual CDPS permit if:

2) The discharger is not in compliance with the conditions of this general permit:

b) Conditions or standards have changed so that the discharge no longer qualifies for a general permit; or

c) Data become available which indicate water quality standards may be violated.

The owner or operator must be notified in writing that an application for an individual CDPS permit is required. When an individual CDPS permit is issued to an owner or operator otherwise covered under this general permit, the applicability of the general permit to that owner or operator is automatically terminated upon the effective date of the individual CDPS permit.

15. Requesting an Individual CDPS Permit

Any owner or operator covered by this general permit may request to be exciuded from the coverage by applying for an individual CDPS permit.

16. Requesting Coverage Under the General Permit

The owner or operator of a facility exciuded from coverage by this general permit solely because that facility already has an individual permit may request that the individual permit be revoked and that the facility be covered by this general permit. Such request shall be evaluated by the Division as per the criteria specified in Part I of this permit. 


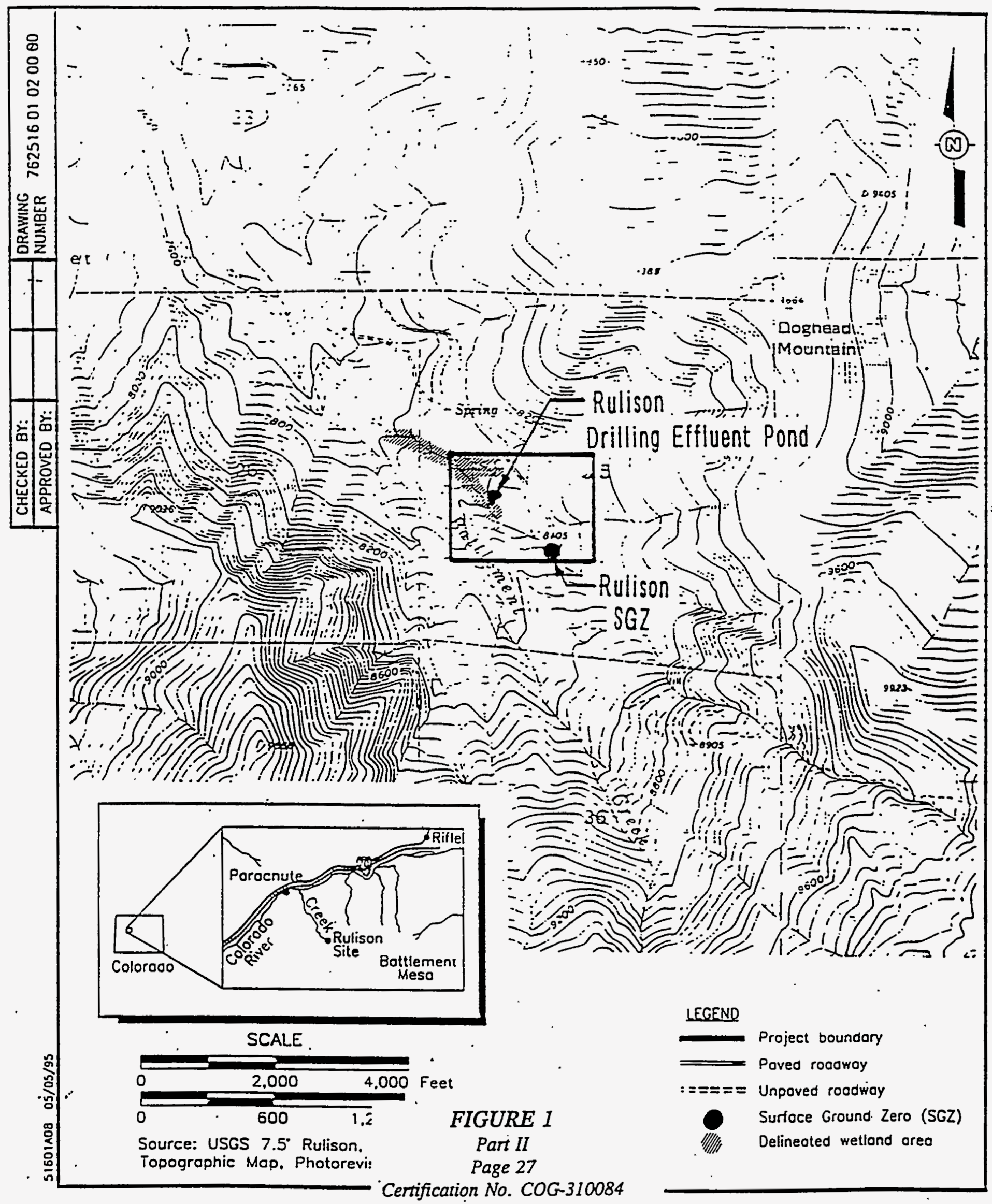

Project Rulison Location Map

Garfield- County, Colorado 


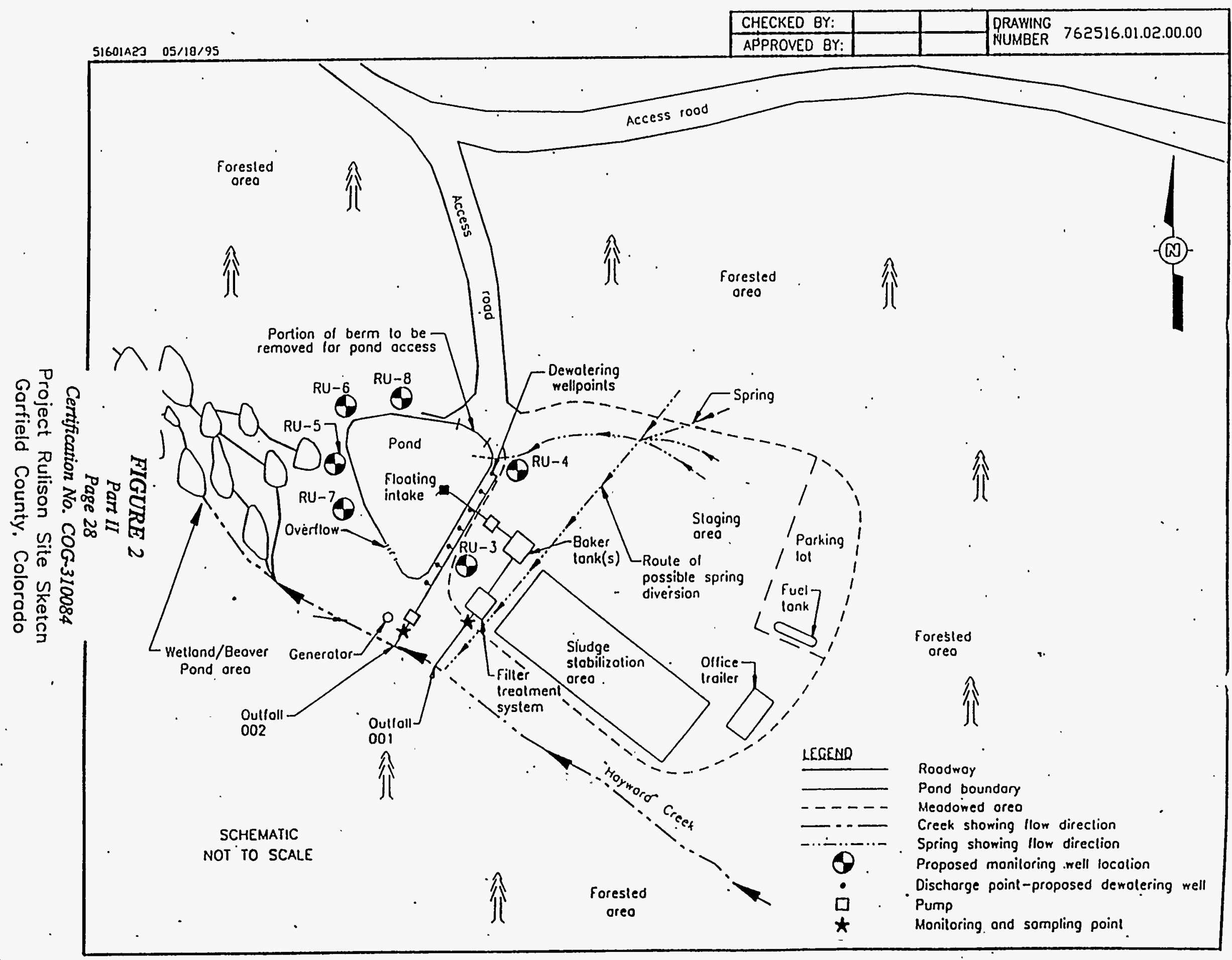


The Diviaion bas laltiated this amendment to the general perwit to include a Flok Volume Exemption, as follows.

The permit is currently kiticen to allow a masimum discharge of 0.05 MGD, or about $35 \mathrm{gpm}$. Thls excludes larger facilities frow.coverage under the general permit. The larger factllties then need to apply for an individual permit, which is desirable so that more frequent monitoring and/or other more btringent controls way be applied. This additlonal control is needed for on-zolng Bystems. However, tiss restrlction bas also resulted in a lack of fletbility in applying this permit. Therefore, the Flor Volume Exemption v1ll be applled under tro separate clrcumstances, as follow:

1) Several cases have ar1sen at alies contrminated or potentially . contaminated by gasoline, where discharge is of a tenporary nature for construction dewatering, and is expected to last for a matter of weeks. Such projects typlcally involve larger volumes of rater, and may be on a t1ghter schedule wish does not allow time for application for an Individual perfit: Therefore, the general permit will be amended so that the marimum flow Ilmit of $0.05 \mathrm{KGD}$ is deleted, for a period not to exceed 30 days, for temporary dekraterfag sites. Thls provision will be approved. by the Division on a case-by-case basis.

2) Mang operators of groundwzter cleanup s1tes.w1sh to begin groundwater remediation as quickly as possible to prevent further sprend of the contamination, but lerger facilities may not be able to because of the flow restriction. Therefore, if the flow from a groundwater remediation site as defined in this permit is greater than $0.05^{\mathrm{MGD}}$, and the Division determines that there 15 no other reason why cleanup should not begin 1mediately, then the permittee my be temporar1ly certifled under this general permit (with no flow Iinit) whlle going through the application process for an 1ridpidual permit. Howeyer, tae permittee must agree ro perIorm addIEIOnal monitor2ng and/or any other requirements the Division may impose during this interim t1me. These requirements will be covered outslde of the permit by letter. Noncompllance with the additlonal requirements could result in revokation of the perditiee's certification under the general permit. 
COLORADO DEPARIMENT OF HEAITH, Water QUaI1ty -CORETOI DIVISIOD Pationale - Page 2. Permit No. COG-310000

PURPOSE OF AHENDMENT:

Therefore, the general permit will be amended to remove the maximum discharge IIm1t of 0.05 MGD, for the two situation described above.

The DIvision reserves the Ifght to refuse a facility coverage under the exemption. The flow volume, level of organtes in the effluent, quality of receiving waters, and/or lack of Information on the treatment system -capablifty will be evaluated. The Divlalon will use best professional judgment in determining whether of not the exemptlon will provide adequate coverage for the discharge.

The remporary dewatering projecrs which use the Flow Volume Eremption have the option of remalniog under the general permit begond the 1nftial pertod, provided that the $0.05 \mathrm{KGD}$ flow limit is wet after the 1nitial 30 days. The 30 day time perlod will start with the flrst day of deratering, and -end 30 days after that, Iegardless of how wany days dewaterlag ectualiy took place in the interim. The permitee must notify the Divibion in sriting if it Intends to use the permit beyond 30 days..

Any request for a Flow Volume Exemptron must be lneluded with the permittee's permit application. See the indiridurl Certiflcetion Rationale to deternine whether of not the exemption is allowed. In any event, no temporary flow lacrease is allowed without pilor Divlalon approval.

Page 2 of the permtt has been amended. Page $2 a$ has been adied. All other permit requirements sinall remain the same.

Kathrya Dolen

July 16, 1991

PUBIIC NOTICE:

No changes were made to the permit as a result of publlc rotice.

Rathryn Dolan

Apr1] 13, 1992 
COLORADO DEPARTMENI OF HEALIH

Water Quality Control Division

4210 East 1Ith Avenue

Denver, Colorado. 80220

\section{RATIONALE}

GROUNDHATER CLEANUP OF GASOLINE

GERERAI- PERMII IN COLORADO

COLORADO DISCHARGE PERMIT NUMBER COG-310000

CONTENTS

$I$.
II.
III.
IV.
$\nabla$.
$V I$.

INTRODUCIION

REFEPENCES
INDUSTRY DESCRIPTION .

COVERAGE INDER TEIS PERHIT

APPIICATION AND CERTIFICAIION

TERHS AND CONDIIIONS OE PERMIT
PAGE

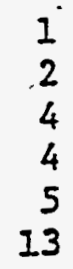

I. INTRODUCIION

Facllitles performing cleanup of gasoline from contaminated groundwater are located in many areas in Colorado. Haters discharged from these faclilites to state waters are subject to the requirements of the State of Colorado "Hater Qual1ty Control Act," I973 as amended. Section 6.10.2 of the "Colorado Dlscharge Permit System Regulations" provides for the Is

1.. Involve the same or substantially similar types of operations;

2. discharge the same types of rastes;

3. require the same effluent IImltations or operating conditions;

4. require the same or similar monitoring; and

5. are more approprlately controlled under a general perwit than under individual permits.

Administrative delays 1n the 1ssuance of a permit to implement remediation might significanty impact the timing and cost of a project, as well as allow the contamination to spread farther. The Weter Quallty Control Division (the Division) has determined that facilities performing groundwater cleanup from gasoline contamination are, In many cases, suitable for coverage under"a general permit. 
COIORADO DEPARTMENT OF HEALTH,. Hater Quality Control Division

Rationale - Page 2. Permit No. COG-310000

\section{IRDUSTRY DESCRIPTION}

It 1 s estimated (by the Hazardous Materials and Haste Management Division) that there are approrimately 25,000 underground storage tanks (USTs) in Colorado, the majority of which are used for storing petroleum products. Variables such as the tank size, age, construction and method used to install and operate the tank dictate the probability of the tank eventually leaking into the environment. The percentage of USTs in Colorado which are leaking 1nto the surrounding environment is unknown at this time. However, past construction practices often did not-take 1nto account concerns about leakage, and so contamination of the groundwater. has resulted at many sites.

Due to the 1ncreased attention (including national legislation) on this 1ssue, many of these contaminated sites have been discovered and are undergoing remediation. Cleanup often consists of pumping contrminated groundwater, treating it, and then discharging the treated effluent to surface waters or a munfipal sewer system, land applying 1t, or re-Injectigg it back 1nto the ground. For discharges of this treated water to surface waters (Including storm sewer systems), a Colorado Discharge·Permit System permit is required.

Gasoline products are mirtures of hydrocarbon compounds with a broad range of physical, chemical and toricological propertes and chemical composit1on. Consequentiy, the concentration of pollutants in wastekețers generated from leaking USTs is highly vartable. Of the types of hydrocarbons found in gasoline, the aromatics are generally considered to be-the most toric, and therefore pose the greatest potential.for. Impact on human health and the environment. Some of the parameters known to be present.1n gasoline are benzene, toluene, ethylbenzene and sylene. Their concentrations in contaminated groundwater will vary depending on the fuel composition and the volatility and solublitty of the compound.. They will be ilmited in the permit based on water guality cIlteria and/or cleanup technology. Organic lead, added to some gasoilnes In the form of tetraethyllead, must also be addressed. Tetraethyllesd is toxic to flsh" larvae at low levels (Ref. H). Inls may lead to problems with the -effluent passing WEI testing.

A. Trestment Technologies

The cleanup operation usuaily lavolves two phases. The flrst phase Includes actions designed to immediately contäin and control a release. The second phase involves assessing and developing long term measures designed to rectify and mitigate.contamination to a level which will protect human health and the environment.

An USI cleaiup typically begins with an effort. to recover free product (1.e., gasoline): This recovery is usually accomplished through the use of a trench (where the fuel collects and is okimmed off), or a pumping well system. A dual pump system uses separate pumps to collect fuel and water, whlle a single pump system sends the fuel/water mix to an above-ground oil/water separator. In each case, 
COLORADO DEPARTMENT OF HEALTH, Hater GaliLy CONTYOI DIVISIOn

Rarionale - Page 3. Permit No. COG-3I0000

\section{IRDUSIRY DESCRIPIION}

the recovered fuel is sent off-site for disposal or re-processing. The wastewater from the o1l/water separator may st1ll conta1n some of the Euel; this is the main source of the contaminants of concera in the discharge.

This wastewater may then be discharged directly from the oil/water separator when there are no.contaminants, or treated in a variery of ways. One common and relativeig economical method of treatment is air stripping. Th1s lavolves providing contact between air and water to. allow the volatile substances to diffuse from the liquid to the gaseous phase. There are several methods of air stripping, including diffused aeration, tray aerators,. spray basins, and packed towers. The packed tower type is the most efficlent, and consists of wastekater sprayed down over media as alt 15 blown up through the . tower.

There are several factors which affect the abflity of air stripping to remove organic pollutants. . Alr strlpping is most amenable to organic compounds with a Henry's Constant value greater than 0.I. (Henry's Constant is a coefficient which describes the tendency for a substance to partition between the Ifquid and gas phases.) The efficiency of alt stripping is also controlled by the temperature of the Hastekater and the 1ntensity or durat1on of the aeration. It may be necessary to . heat the wastewater prlor to alI stripping, and /or to recycle the: wastewater or add more treatment unts to achieve the necessary removal efficiencies. Because of the Iluited area required for these facilifles, and the lack of a need to change the media, this method is economical in man situations. It should be noted that there way be air pollution considerations with thls type of treatment (Ref. F).

Another common treatment merhod is granular activated carbon adsorption, used elther separately or in comblnation with ait 6rripplag. Activated carbon is more expensive than 'alrstripping." Use : of activated carbon systems is most effective on 1nfluent with low levels of organics present. The wastewater is brought into contact with the activated carbon, whlch then selectively adsorbs organic constituents into the internal pores of the carbon granules. As solublilty of the compound decreases, the compound is more likely to be adsorbed. Thus, factors which will affect the solubillty of the compound, suct as.p $\mathrm{H}$ and temperature, will affect how well a substance Is removed vis carbon adsorption. It is suggested (Ref. D). that organlc lead may be removed by activated carbon. Laboratory tests put this removal at $58-96 \%$.

The carbon in such systems needs to be regenerated or replaced on a routine basis, which adds to the cost of the treatment. In addition, use of activated carbon may, be impractical if the wastewater contains high levels of 1ron and manganese, which can use up the adsorptive capacity of the carbon and thus not allow 1 to fully remove the organics (Ref. E). 
COIORADO DEPARIMENT OF HEAITH, Weter QuaI1TY CONTIOI DIVIsion

Rationale - Page 4. Permit No: $\infty G-310000$

\section{INDUS IRY DES CRIEIION}

Other wethods for treatment of organics include bloremediation, reverse osmosis, ozonation and ultraviolet irradiation. These methods are still being developed: As they are refined and become more cost effective, their use will become more uidespread. This permit does not specify the type of treament to be used, and so does not require thet any of these methods be used. It should be noted that no one treatment method is applicable to all organics. Treatment systems, if needed, must be chosen wilch work best given the specific site and wastewater characteristicss

\section{COVERAGE UNDER THIS - PERMIT}

Under this genergi permlt, owners and operators of groundwater cleanup operat10ns for gasoline or aviation gasollne may be granted authorizarion to discharge treated groundrater lnto waters of the State of Colorado. Other petroleum products, such as avlation turbine fuel, kerosene, and dlesel fuel are-not covered under this permit.

Authorization under the permit shall require prior submittai of certain factilty information. Dpon recelpt of all requised information, the permit 18suirg authority may allow or disailow coverage under the general peralt.

The folloning ILst shows the criteria which will be used is eveluating whether or not an Individual permit may be required lostesd of a generai permit: :

1. proxtmity of the operation to a landfill or wine and mill tallings;

2. evidence of 81 gafleant noncompliance under a prevlous permit for the operation;

3. an effluent flor grester than $0.05 \mathrm{MGD}(50,000 \mathrm{gpd})$;

4. the need to preserve high quality water;

5. addition of flocculants (setting agents or chemical additives) to water prior to discharge;

6. use of chemfols (such as chlortae) vithin the treathent aystem;

7. Eallure of the effluent to pass a hole Effluent Toxdefty (WET) test;

8. Iesd or organics levels in the effluent which could lead to a vlolation of the recelving waters lostresm vater quallty standsrd for lend or organics, respectively;

9. presence of downstresm drinking water Intakes or a f1shery;

10. an anti-degradation review by the DIvision shoring that the discharge would cause wallowable degradation to the recelving waters.

\section{APPIICATION AND CERIIEICATION}

At least thirty days prior to the antlchpated date of discharge, the okner, operator and/or authorized agent for a facility shall oubult an application as provided by the Division. Thls applicarlon will be evaluated utilizing the criteria outlined previousiy.. If the general permit is applicabie to the applfcant's operat1on, then a rationale will 
COLORADO DEPARTMENT OF HEAITH, Water Guality COATIOI Division

Rarlonale - Page S. Permit No. COG-3I0000

\section{APPLICATION AND CERTIFICÁTION}

be developed and the applicant will be certifled under this general permit. The rationale shall include, at a minimum, the name and address of the contact person, the person responsible for the operation, a description of the facillty, the receiving water, the number of outfalls,

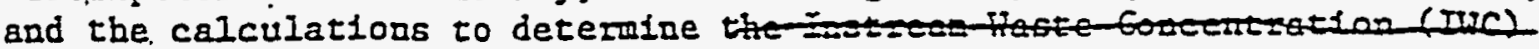
the benzene Ifmit. A determination on the need for sallnity monitoring and a lead Ilmit shall also be included.

The DIviston shall have up to thirty days after recelpt of the above inforwation to request add1rlonel data and /or deng the authorization for any particular discharge. Upon receipt of additional information, the: Divialon shall have an additionel 30 days to issue or deny authorizarion to discharge.

If the applicant does not. Iecelve a request for additional informat1on or a notiflcation of denfal from the Division within 30 days, authorlzation to discharge in accordance with the conditions of the permit shall be deemed granted.

If, after evaliuarion of the applicat1on, 1t. Is found thst the general permit is not applicable to the operation, then the application will be processed as one for an Individual perait. The applicant will be notifled of the Division's decision to deng certification under this general peralt. For an individual pernit, 180 days w117 be required to process the applfeat100 and 1ssue the permit. In thls case, a discharge cannot take place unt1l the permit is issued and becomes effective:

An existing source may request coverage under the general permit. If; after evaluation of the application for an erlating source wilch is already covered under an. Individual permit, it is found that the general permit is not applicable to the operation; then the applicant. w111 contlnue operation under the existing individual permit.

If facilfty condft1ons change such that coverage under the general permit 16 no longer applicable, the permittee hill be required by the Division to apply for an individual permit. Determination of toricity of the effluent alone 15 grounds for the Division to convert the facilits to coverage under an individual permit. Coverage will continue under the general permit until 1ssuance of the individual permit.

\section{TERMS AND CONDITIONS OF PERHII}

\section{A. Effluent IImitations}

In developing suitable effluent Iimitations, the Division must seview all applicable standaris and regulations and apply that which is more stringent. 'This review includes, but is not limfted to, the water quality sțandard-based effluent limftatlons, federal guldelines.and srandards ( $40 \mathrm{CR}$ Subchapter $N$ ) and "Regulations for Effluent Iimitations" (Ref. B). Such a reviek has been dane for this permit. The following limits will apply and are discussed in Table V-I. 
COLORADO DEPARTYENT OF HEAITH, Hater Cual15y Control Division

Rationale - Page 6. Permit No. CCG-310000.

V. TERMS AND CONDITIONS OF PERMII

Iable V-I - Effluent Limles

Parameter Ifmit : Rationale

FIOH, KGD

TSS, $\mathrm{mg} / \mathrm{I}$

DFi, s.U.

011 and Grease, $0 g / I$

Potent1aliy Dissolved Lead, mg/2 (only if required)

Benzene, mg/I

BETX, mg/1

Whole Effluent Toxicity, Acure

I. Dissolved Sollds, mg/I

(Colo. River Basin only)

$$
\begin{aligned}
& \text { See Certification } \\
& 30 / 45 \mathrm{al} \\
& 6.5-9.0 \mathrm{~b} / \\
& 10 \cdot \frac{\mathrm{c}}{} \\
& 0.031 \mathrm{c} / \mathrm{d} / \\
& \text { See Certification } \\
& 0.1 \mathrm{cl}
\end{aligned}
$$

See DLscussion

Monftor ODIY
Design

State Effluent Regulations.

Water Guality Standards

State Effluent Regulations

Water Guality Standards Basic Water Quality Standards Best Professionel Judgment.

Discharge Permit Regulations

Salinity Regulations

a/ 30-Day Average/7-Day Average

b/ Minimum-taximum

cf Dails Kaximum

df The lead limit is applicable only to those factIlties which discharge to streams which have an Instream lead Ifmit; or which could impact such a stream.

\section{Hater Qual1tr Standard-Based Effluent ISmitát1ons:}

a) Iead: For individual permits, a mass balance equation is.used. - to determine the effluent concentrations for lead, the linlts for which are based on the water quality standards. However, due to the complerity of the calculations for this parameter. and the time constralats involved in lssutng a general permit certification, it is not feasible to include such a colculation-based limit in a general permit. Therefore, a limit for potentlally dissolved lead of $0.031 \mathrm{mg} / \mathrm{I}$ (daily maximum) will be imposed: This is based on an assumption of workt-case conditions: minimal dilution provided by the recelving stream, and an Instream hardiness value of $50 \mathrm{mg} / 1$, applofig the table value for lead as outlined in the "Basle Standards and Methodologies for Surface Hater" (Ref. A). Although this. may be a strlcter Ifmit for some factilties than a calculation-based one would be, the permittee still has the optlon of ipplying for an individual permit in order to come under the calculationbased Iimit. 
COLORADO DEPARTMENT OF HEAITH, Hater QualiEy COHEIOL Division

Rationale - Page 7 . Permit No. COG-310000

\section{TERMS AND CONDITIONS OF PERMIT}

The lead limit will anly be applicable to those facilities which discharge to streams wich have an instream lead Ilnit, or which could impact such a stream. Monitoring for lead will be réquiréd at all facilities..

See the individual Certification Rationale for the receiving stresm, and a discussion on whether a lead Iimit is applicable to the individual facility.

b) Benzene: Benzene is a comonoly found concaminant in fuel cleanups. Benzene is Iimited in the "Basic Standards and Methodologies for Surface Water," 3.1.11. A mass balance equation. Is used to determine the effluent concentration for this paramerer. The mass balance equation 1s:

$$
M_{2}=\frac{M_{3} Q_{3}-M_{1} Q_{1}}{Q_{2}}
$$

Where: $Q_{1}=$ Jpstream Iot flow:

$Q_{2}=$ Effluent flow (chronfc)

$Q_{3}=$ Combined downstream fIow $\left(Q_{1}+Q_{2}\right)$

$M_{1}$ - Opstream background poLiutant concentration

$M_{2}=$ Daknown; effluent poilutant concentration

$\mathrm{M}_{3}=$ Basic Hater QuaIity Standard

The Division does not have Instream data avallable for benzene. Therefore, the background level $\left(H_{I}\right)$ is assumed to be zero.'. The value for $_{M_{3}}$ varles depending on the receiving water classification. For a water supply, the instream chroutc limit is $0.005 \mathrm{mg} / 1$. For an aquarlc Iffe classiflcar10n, the Instream. acute I1mit is $5.3 \mathrm{mg} / 1$. The effluent flow used $\left(Q_{2}\right)$ 1g the 30 day average flow fiom the facility, since the acute ilmit will not be applied. The: upstream low flow $\left(Q_{1}\right)$ is calculated by the Division using a set protocol.

If the caiculated benzene Iimit is greater thsin 0.1 mg/I, then the BETX 1 imit of $0.1 \mathrm{mg} / 1$ (as discussed belov) wlll dictate the marimum benzene level allowed, and so a separate benzene limit will not be included. (This is why, for receiving waters which are classifled for aquatic life, the benzene-calculation is not appropriare, since the instream Iimit is aiready greater than the BETX Ilmit.) Monttorlng for benzene will ot1Il be required for all facilities, hovever. If the calculated benzene Ifmit is equal to or less than $0.1 \mathrm{mg} / 1$, It will be applied to the facility. 
COLORADO DEPARTMERT OF HEALTH, Water QuaIItY COntrol Division

Rationale - Page 8. Fermit No. COG-3I0000

\section{TERMS AND CONDIIIONS OF PERMIT}

See. the Individual Certification Rationale for the actual calculation, and a discussion on which limit the. Individual facility will be required to meet.

2. Applicable Federal Effluent Guidelines and Standards: Although no federal guidelines have been promulgated for this type of facility, EPA has come out with guidance on ruch permits (Ref. E). Th1s guldance was used in developlag a technologg-based IImit for BETX.

BEIX means the combined total of benzene, ethylbenzene, toluene and rylenes in the effIuent. It is a comon petroleum Industry practice to deteraine the qualfty of fuels by measuring BETX.

Nonttorlang and Ifmitarlon of BETX in discharges from this type of facillty is prudent for several reasons. Flrst, the composition of gasoline is tighly variable and for some gasoline products, any one of. the four BEIX constituents can be the predomfant constituent. Second, EPA has promulgated or proposed water quality criteria for benzene, ethylbenzene, toluene and the rylenes. Except for napthalene, crlterla hsve not been proposed for the other const1tuents of gasoline. AIso, the consc1tuents of BETX have. Iok Henry's Iaw Constants, which weans they are not as easily ait stripped as other gasollne const1tuents, and-so are a good ludicator of treatment effectiveness:

The BEIX. IImit is deifyed using Best Professional Judgment of what the Best Avallable Technology is for treating the wastewater. According to EPA, the potential removal effictency of BETX using a comercially avaliable aif stripper unlt is 99.5 percent. If ali strlpplag is applled to Influent BEIX levels of $15 \mathrm{mg} / 1$ (the estimated marimum influent level of BEIX after the product recovery . phase), the strlpped effluent would contaln $0.075 \mathrm{mg} / \mathrm{i}$ total BEIX:. Since product recovers and ait strlpping technologies inas not alvays occur under optimal conditlons, the total BEIX discharge Itreit will be slightiy increased to $0.1 \mathrm{mg} / \mathrm{I}$ (dalig marimum).

3. Regularlons for Effluent Limitations: The Regulations for EffIuent Ifoltations" (Ref. B), appIs to the conventional pollutants. For this permit, the Ifoltations for TSS and 011 and Grease are based on this regulat1on. :

4. Discussion of Ifimitations:

a) Flow: A flor limit is included in the permit, due to the benzene limit being flow-based for some faclilties. The flow Ilofit used 1111 be the 30 day average flow (design) frow the facillty, since the limits imposed are chronic ( 30 day average). See the individual Certification Ratlonale for the flow Ilmit applicable to the Individual facility. 
COLORADO DEPARTHENT OF HEALTH, Hater Qual1ty Control Division

Rationale - Page 9. Permit No. COG-310000

\section{TERMS AND CONDIIIONS OF PERMIT}

b). Salinits: Salinfty, or total dissolved solfds (IDS) Is an 1ssue In the Colorado River Basin. Regulation 3.10.0, "Regulations for Implementation of the Colorado Rfver Salinity Standards Through the Colorado D1scharge Permit Program," addresses the " discharge of IDS to the Colorado River Basin. It is a requirement of the regulation that the salinity of each discharge in the Colorado River Basin be evalusted for impact on the system. General1y, the net impact on salfnity to the basin from groundwater cleanup activities 1s. expected to be negliglble, because the waters are typically shallow groundwaters which wiIl eventualiy reach the river, and because. the discharge volume is usually low. Nonetheless, the Stare reserves the rlght to refuse the applicabilfty under the general permit of any groundwater cleanup operation, if it appears that the discharge w1ll not be consistent with the Ieguiation.

Additionaliy, quarterly monitorlng for IDS will be a peralt requirement for ail facilfties located in the Colorado River Basin: Should the data 1dentify a probiem, the State w1ll bave the right to require the facillty to-obealn an individual permit, whereigy a study addressing the econonic feasibility of salt removal can be required.' See the individual Certiflcation Rationale that accompanies the permit for the Division's . determination of whether or not salinity mont toring is required.

5. Whole Effluent Todclep (WET) Test1ng: For this facillty, acute WET testing is requiled. (See Parts I.B and I.C of the permit, $8 s$ well as the Individual Cereification Rationsle.) Honitorlng shall be performed commencing fith the first full calendar quarter following the certification effective date.

a) Purpose of WET Test1ng: Section 6.9.7 of the "Reguilatlons for the State Discharge Permit System" (Ref. C), passed by the Uater. Quality Control Commssion, has established the use of WEI testing as a method for 1dentifying and controillng torlc. discbarges from rastekater trearment facileties. FET testing is

- being urflized as a means to ensure that there are no discharges "In amounts, concentrations or combinations which are harmful to the beneflcial uses or. tortc to humans, suimals, plants, or aquatic Iffe" as Iequiled by Section 3.1 .11 (I)(d) of the Basic Standards and Methodologies.

Chemlcal analyals of effluent has provided only a pertiel evaluation of the potentlal 1mpact a discharge could have on the recelving stream. Also, chemical analysis cannot evaluate the synergistic or antagonistic effect of compounds. There are also 
COLORADO DEPARIMENT OF HEAITH, Hater CuaIIty COntIOI DIvislon

Rationale - Page 10. Eermit No. COG-310000

V. TERHS AND CONDITIONS OF PERIT

compounds for which an accurate or reproducable method of chemical analysis has nor yet been developed, as well as compounds which are just-beglaning to be evaluated for toric effects. HET testing will provide a more comprehensive mears of evaluating the toricity of a discharge than could otherwise curtently be accomplished.

b) Species Toriclty: As a condition of the permit, the permittee will be required to conduct rourlne monitoring for acute toricity using two species, Cerlodaphala 6p. (water flea) and fathead minnows. Acute toricify occurs when a spectes mortality In any dilution of effluent (Including $100 \%$ effluent) exceed6. 507 for elther species, or there is a statistically sigalficant difference in the mortality observed for elther spectes berween the control and any effluent concentration.

Should acute torfcity be detected, discharge must be haited 1mmediately. The permittee must subuit a report to the Division Whthin 5 days of the toricity being detected, outilning the steps proposed to determine the cause of the toxiclity. In most cases, this will 1nvolve conducting a series of accelerated tests to show whether the torichey was contruous or an lsoleted incldent. (Effluent from this type of facillty is expected to be relatively consistent.) In those cases where a real or potential KET problem has been established, the permittee nust apply for coverage under an Individual perali, which will Include imposition of HEI Ilaits. (Steps must also be taken to ldentify the source of torlcity, and propose suitable treatment, before an Iridividual permit can be issued.)

The permittee should read the HEI testing sections of Part I.B and I.C of the permit carefully, and should note that the test methodB. for the toricity tests are described in detatl in the Division. guidance document, Guidelines for Conducting thole Efeluent. Toricity Tests. This document should be Iead thoroughly pIlor to comencing the required HET test1ng, to ensure that the permittee Is aware of the various test conditions that-could affect the testresults (e.g., sample holding time).

The permittee should be aware that ellgiblilty for coverage under the general permit may change if the facilety erperiences a change In discharge, as outlined in Part II.A.I of the permit. Such changes shall be reported to the Division immediately. 
COLORADO DEPARTMENI OF HEAIIH, Hater Quallty COntIOI DIVISIOD

Ratlonale - Rage 11. Permit No. COG-310000

v. IERMS AND CONDITIONS OF PERMIT

B. Monitoring and Reporting

1. Montroring: Table $\nabla-2$ Ilsts the monitoring requirements for this permit, lncluding sample type and frequency.

Table V-2 - Montroring Requirements

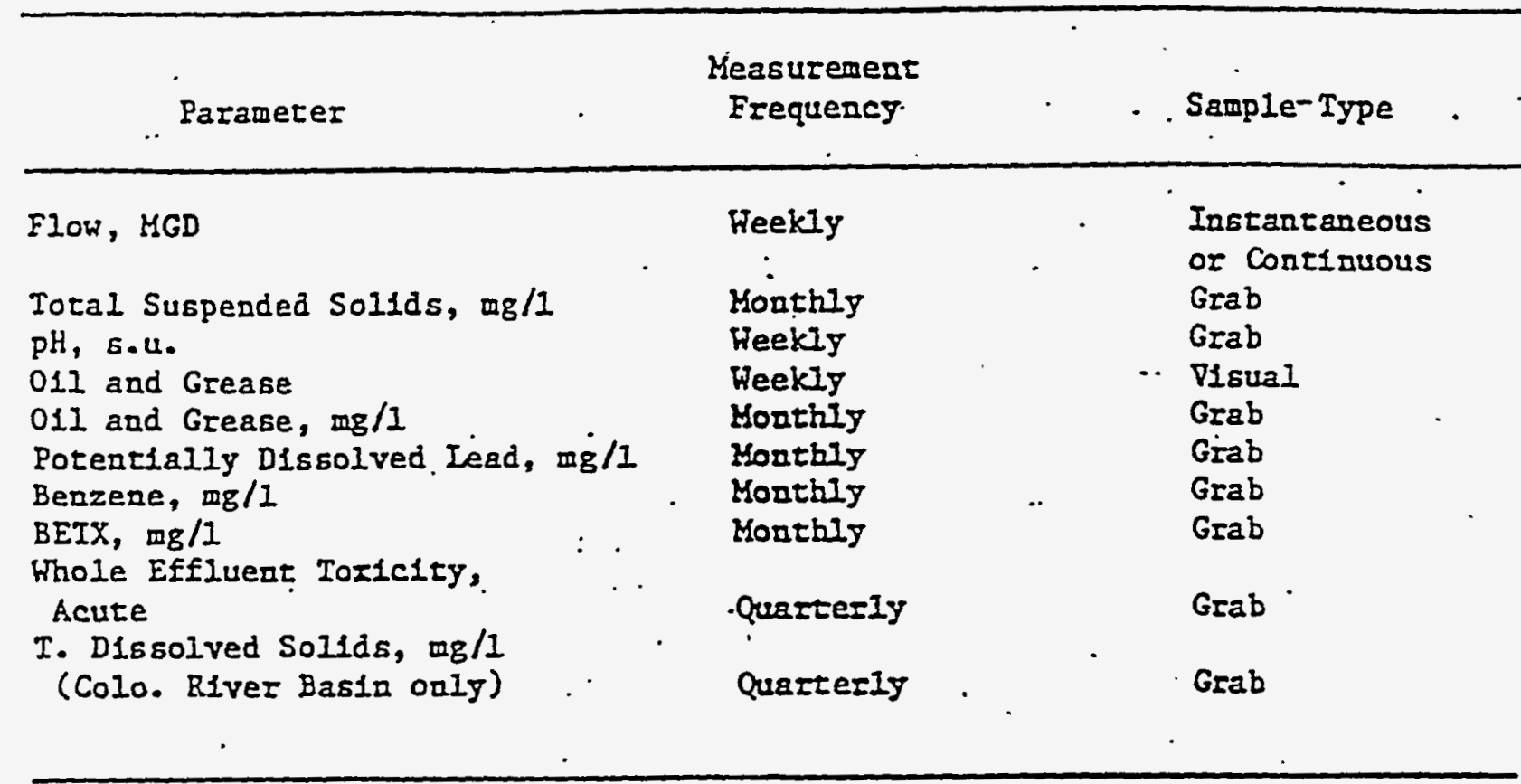

2. Report1ng: The permittee must submit a Discharge Monttoring Report (DKR) on a monthly basis to the Diviston. This ieport should cortaln the required summarlzation of the test results for parameters shown in Table $\nabla-2$ and.Part I.C.I of the permit. See the permit, Part I.C.? for detalls on such. subulssion.

3. Add1tional Monttoring and Report1ng: In additton to the routine monttoring discussed above, the permittee fill be required to wonitor for the entsre volatile fraction of the organic toric poliutants, once per jear, beglouing within three months of the effective date of the certification. If the new data lndicate the presence of any organics at levels which ulght vlolate the organic pollutant.standards contained In tables $A, B$ and $C$ of "The Basic Standards and Methodologles for Surface Hater" (Ref. A), the Divibion reserves the Ilght to require the: facilfty to obtain an Individual permit.

C. Additional Terms and Conditions

1. Splll Contalament: As most fac1litles provide bulk storage of some volume of gasolines or other chemicals, the permit will require 
COIORADO DEPARTMENI OF EEAITH, Hater Quality COntrol DIV1sion

Rationale - Page 12. Permit No. COG-310000

\section{IERMS AND CONDIIIONS OF PERMII}

1. Soll1 Contaloment: (Cont.) adequate protection from spills for. buch facllifles 50 as to prevent $10 s$ of these materlais into discharged waters. Such protection can take varlous forms; horever, diking in most cases will prove to be the most cost effective. This provision is required as the Pivision interprets proper operation as properly addressing potential pollutant sources before problems occur.

Splil reports wili cnis be required in cases of noncomplinace with. permit conditions. The permittee will, however, be required to maintain 1ts records for a perlod of three years. Such records w1Il be subject to inspecrion by EPA and/or the Division. -

2. Duration of Permit: The permit shall not exceed five gears in duration. The permitite' 's authority to dischorge under this permit is epproved until the expiration date of the general perult. The . permittee mus apply for recerteflcation inder the general perndt at lesst 180 days prior to its expiration date..

Rathrya Dolan November 15,1989

D. Changes Eolloring Public Notlce

The following changes were made in the permt ifter revier of coments received during the public notice period:

1. Coverage of diesel fuel contamination was deleted, due to the constltuents of diesel fuel, winl ch are best determined by analyses for actd and base-aeutral organics, not rolatiles.....

2. Coverage for faclittes with effluent volumes over $0.05 \mathrm{MGD}$ was deleted, so that more frequenc monitoring could be applied to larger.facllities. However, such operations could still apply for temporary coverage under the general permit, if they met the 0.05 MGD flow. Ilutt while an individual permit is processed.

3. The requirement that discharge be imediately terminated if torlcity is 1dentifled is clarifled.

4. A requirement has been added stating that if discharge is to a storm sewer system, ipproval from the owner of the system must be. obtained prior to certification. 
"COLORADO DEPARTHENT. OF HEAITR, Hater Quality Control DIVIEIon

Rationale - Page 13. Permit lio. COG-310000

VI. REFERENCES

A. Colorado Dept. of Health, Hater Quality Control Commission. Basic Standards and Methodologies for Surface Water (3.1.0). Denver: CDH, as revised $8 / 7 / 89$.

B. Colorado Dept. of Health, Hater Quality Control Commission. Regulations for Efflueni Iimltations (10.1.0). Denver: CDH, as revised $1 / 6786$.

C. Colorado Dept. of Hezlth, Water Quality Control Commission. Requlat1ons for the State Discharge Perm1t System $(6.1 .0)$; Denver: : CDH, as revised $8 / 31 / 89$.

D. Patterson, James H. Industrial Hastekater Treatment TechnolögY, Second Edit1on: Boston: Butrerkorths, 1985.

E. D.S. Environmental Protect10n Agency. Kodel NPDES Permit for Discharges Resuling from the Cleanuo of Gasoline Released from Dnderground Storage Tanks. Wash., D.C.: J.S. Gov't'Printing Office, $6 / 89$.

F. U.S. Environmental Protection Agency. Cleanuo of Releases from Petroleum OSTs: Selected Technologies (EPA/530/UST-88/00I). Wash., D.C.: U.S. Gov't PIInting Office, 4/88.

G. State of Utah, Division of Environmental Bealth. General Perait for Ireated Groundwater Contaminated with Petroleum products (draft). Stace of Utah, 2/89:

A. Verschuerea, Karel. Biandbook of Environmental Data on Organic Chemlcals, Second Edit10n. Net. York: Van Nostrand Reinhold Company, 1983. 
$-$

1 


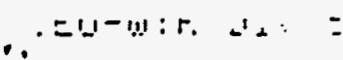

Form No.

OFIFICE OF THE STATE ENGINEER

GWS-25

COLORADO DNISION OF WATER RESOURCES

818 Ceniennlsl B'do.. 1313 Shnrman S1. Denvar, Colorasio 80203

(303) BCE-35-91

APPLICANT

WEL PERMTT NUMBER

DIV. 5. CNTY. 23. WD

18388627

45 DES. BASIN

MD

Lot: Block: Flling: Subdiv:

US DEPT OF ENERGY

\%ROXANNE DANZ

BOX 98518

LAS VEGAS NV $89193-8518$

(702)295-7723

PERMT TO CONSTRUCT A WEL

\section{APPROVED WELL LOCATION GARFIELD COUNTY}

NE $1 / 4 \quad$ SW $1 / 4$ Secilon 25
TwP $7 S$ RANGE $95 \mathrm{~W}$ 6th ।

\section{DISTANCES FROM SECTION LINNES}

$1700 \mathrm{Ft}$. from South Section Line

3500 Ft. from East Section Line

\section{ISSUANCE OF THIS PERMIT DOES NOT CONFER A WHATER RIGHT CONDTIONS OF APPROVAL.}

1) This well shall be uscd in such a way as to cause no material injury to exisling water rights. The issuance of permit does not assure the applicant that no injury will occur to another vested water right or preclude ano owner of a vested water right from sooking relief in a civil court action.

2) The construction of this well shall be in compliance with the Water Well Construction Rules 2 CCR 402-2, unt approval of a variance has been granted by the State Board of Examiners of VJater Well Construction and PL. Installation Contractors in accordance with Rule 18.

3) Approved pursuant to CRS 37.92-602(3)(b)(1) for uses as describod in C.9S $37.92 .602(1)(1)$. Use of this we limited to monitoring water levels and/or wator quality sampling.

4) This well must be equipped with a locking cap or seal to prevent well contamination or possible hazards as open well. The well must be kept locked at all times except during sampling or measuring.

5) Records of water level measurements and water quality analyses sinall be maintained by the well owner: submitted to the Division of Water Resources upori request.

6) Upon conclusion of the monitoring program the well owner shall plug this well in accordance with the Water Construction Rules. A well plugging report must be completed and submitted to the Division of Water Resour. within 60 days of plugging.

7) The owner shall mark tho well in a conspicuous place with well permit numberand namo of aquiler:as approprii and shall take necessary means and precautions to preserve these markings.

8) This well must be constructed by or under the supervislon of a llcansed woll drillor or other authorized individ according to the Water Well Construction Rules.

.9) A well completion repon including lithologic log must be submitted by the individual authorizod to construct

$\checkmark$ well. For non-standard construction the report must include an as.bullt drawing showing detalls such as def casing, perforated zones, and a description of the grouting type and Interval. This woll is known as RU-1.

10) This well shall be constructed not more than 200 feet from the location specified on this pernil.

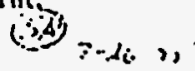

\section{DIVISION COPY}

APPROVED
SGA
ROCOIPT NO. $0386347 \mathrm{~A}$


WELL PERMIT NUMBER

DV. 5 CNTY. 23 WD 45 DES. BASIN MD
Lot: Block: Filing: Subdiv:

\section{5}

\section{APPROVED WELLL LOCATION GARFIELD COUNTY}

US DEPT OF ENERGY

GROXANNE DANZ

BOX 98518

LAS VEGAS NV 89193.8518

(702)295-7723

PERMIT TO CONSTRUCT A WELI
NE $1 / 4$ SW $1 / 4$ Section 25

TwP $7 \mathrm{~S}$ RANGE $85 \mathrm{~W}$ 6th

\section{DISTANCES FROM SECTION LINES}

$1820 \mathrm{Fl}$. from South Section Line

$3450 \mathrm{Ft}$. from East Section Line

ISSUANCE OF THIS PERNIT DOES NOT CONFER A WATER RIGHT CONDITIONS OF APPROVAL

1) This yoll shall be used in such a way as to cause no matorial injury to exlsting water rights. The issuance 0 permit does not assure the applicant that no injury will occur to another vestod water right or preclude anc owner of a vested water right from seeking reliet in a civil court action.

2) The construction of this well shall be in compliance with the Water Well Construction Rules 2 CCR 402-2, ur approval of a variance has been granted by the State Board of Examiners of Water Woll Construction and $P$ Installation Contractors in accordance with Rule 18.

3) Approved pursuant to CRS 37-92-602(3)(b)(1) for uses as described in CRS 37-92.602(1)(1). Use of this w limitod to monitoring water levels and/or water qualiny sampling.

4) Thls well must be equipped with a locking cap or seal to prevent well contamination or possible hazards a open well. The well must be kept locked at all times except during sampling or measuring.

5) Records of water level measurements and water quality analyses shall be maintalned by the well owner submitted to the Divlsion of Wator Resources upon request.

6) Upon conclusion of the monitoring program the weil owner shall plug this well in accordance with the Water Construction Rules. A well plugging report must be completed and submitted to tho Dlvision of Water Resou within 60 days of plugging.

7) The owner shall mark the well in a conspicuous place with well permit number and name of aquiler as appropr and shall take necessary means and precaullons to preserve these markings.

8) This well must be constructed by or under the supervision of a llcensed vell driller or other authorized indivl according 10 the Water Woll Construction Rules.

9) A well completion report including lithologic log must be submitted by the indlvldual authorized to construc well. For non-standard construction the report must include an as-bullt drawing showing detalls such as dc casing. perforated zones, and a description of the grouting type and interval. This well is known as RU-2

10) This well shall be constructed not more than 200 feet from the location speclied on this permit;

\section{DIVISION COSY}

$\begin{aligned} & \text { APPROVED } \\ & \text { SGA } \\ & \ddot{R}\end{aligned}$
Receipt No. 03863478


Form No. OFFICE OF THE STATE ENGINEER .

- GWS-25 COLORADO DNISION OF WATER RESOURCES

Bis Contonnisl eldd., 1313 shorman St., Desver, Coloredo 80203

(303) 860.3501

WELL PERMTT NUMBER

1888665

DIV. 5 CNTY. 23 WD 45 DES. BASIN

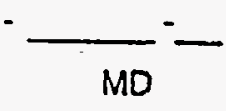

Lot: Blook: Flling: Subdiv:

US DEPT OF ENERGY

\%ROXANNE DANZZ

BOX 985.10

LAS VEGAS NV 89193.8518

(702)295-7723

PERMIT TO CONSTRUCT A WELL
APPROVED WELL LOCATION

GARFIELD COUNTY

NW $1 / 4$ SW $1 / 4$ Section 25

TwP $7 S$ RANGE $95 \mathrm{~W}$ 6Ih P.M.

DISTANCES FROM SECTIION LINES

2150 Ft. from South Section Line

4100 Ft: from East 'Section Line

ISSUANCE OF THIS PERMIT DOES NOT CONFER A WATER RIGHT CONDFTIONS OF APPROVAL

1) This well shall be usod in such a way as to cause no material lnjury to existing water rights. The issuance of the permit does not assure the applicant that no injury will occur to another vested wator right or preclude another owner of a vested water right from seeking relief in a clvil court action.

2) The construction of this well shall be in compliance with the Water Well Consituction Rulos 2 CCR 402.2, unless approval of a variance has been granted by the State Board of Examiners of Water Wel! Constructlon and Pump Installation Contractors in accordance wilh Rulo 18.

3) Approved pursuant to CFS 37-92.602(3)(b)(1) for uses as described in CRS 37-92-602(1)(1). Use of this well is limited to monitoring waler lovels and/or water quality sampling.

4) This well must be equipped with a locking cap or seal to prevent well contamination or possible hazards as an open well. The well must be kept locked at all times except during sampling or measuring.

5) Records of water level measurenents and water quality analyses shafl be maintained by the well owner and submitted to the Division of Water Resources upon request.

-6) Upon conclusion of the monitoring. program the wall owner shall plug this well in accordance with tho Wator Well Construction Rules. A well plugging report must bo completed and submitted to the Division of Water Resources within 60 days of plugging.

7) The owner shall mark the well in a consplcuous place with well pernit number and name of aquifer as appropriate, and shall take necessary means and procautions to presorvo theso marklngs.

8) This well must be constructed by or under the supervision of a licensed well driller or other authorized individual according to the Water Well Construction Rules.

9) A well completion report including lithologic log must be submitted by the individual authorized to construct the well. For. non-standard construction the report must include an as-built drawing showing details such as depth, casing, porforated zones, and a description of the grouting type and Interval. This well is known as RU 3.

10) This well shall be constructed not more than 200 feet from the location specified on this permit.

\section{DIVISIOR COPY}

APPAOVED SGA

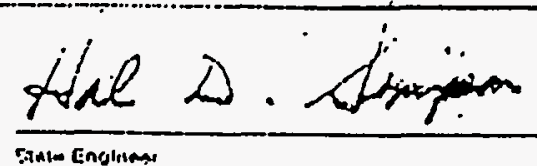

sanis Englinas

Recoipt No. $0336347 \mathrm{C}$
DATE ISSUED JUL $27 \$ 995$

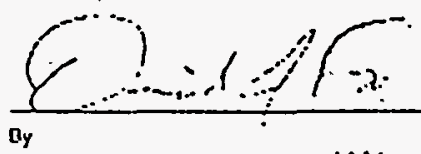

EXPIFATION DRTE IUL -27 fgn? 
Form No. OFFICE OF THE STATE ENGINEER

. GWS-25 COLORADO DIVISION OF WATER RESOURCES

o18 Centennini Dldig. 1313 Shorman St. Denvor. Colorado 80203 (303) 866.3521

LIC

\begin{tabular}{|c|c|c|c|c|c|c|c|}
\hline & \multicolumn{3}{|c|}{ WEU PERMIT NUMBER } & \multicolumn{3}{|c|}{1 ESBSG' } & \multirow{2}{*}{$\frac{}{\text { IVD }}$} \\
\hline & DIV. 5 & CNTY. & 23 & HD & 45 & DES. BASIN & \\
\hline
\end{tabular}

Lol. Block: Filing: Subdiv:

\section{APPBOVED WELL LOCATION \\ GARFIELD COUNTY}

US DEPT OF ENERGY

$\%$ ROXANNE DANZ

BOX 98518

LAS VEGAS NV 89193.8518

(702) 295-7723

PERMIT TO CONSTRUCT A WELL

NW $1 / 4 \quad$ SW $1 / 4$ Section 25
Typ $7 S \quad$ RANGE $95 \mathrm{~W}$ Gth P.M.

DISTANCES FROM SECTION LINES

$2300 \mathrm{Ft}$. from South Saction Line

$4010 \mathrm{Fl}$. from . East Section Line

ISSUANCE OF THIS PERMIT DOES NOT CONFER A WATER RIGHT

CONDTIONS OF APPROVAL

1) This woll shall bo usod in such a way as to cause no material injury to existing vater rights. The issuance of the permit does not assure the applicant that no injury will occur to another vested water right or procludo another owner of a vested water right from seeking refief in a civil court action.

2) The constructicr. of this well shall be in compliance with the Water Well Construction Rules 2 CCR 402-2, unless approval of a variance has been granted by the State Board of Examiners of Water Well Construction and Pump Installation Contractors in accordance with Rule 18.

3) Approved pursuant to CR.S $37.92-602(3)(\mathrm{b})(1)$ for uses as described in CRS $37-32-602(1)(f)$. Use of this woll is limited to monitoring water levels and/or water quality sampling.

4) This weil must be equipped with a locking cap or seal to prevent well contamination or possible hazards as an open well. The woll must be kept locked at all tinies except during sampling or measuring.

5) Records of water level measuremonts and water quality analyses shall be maintained by the well ouner and submitted to the Division of Water Resources upon request.

i) Upon conclusion of the monitoring program the well owner shall plug this wall in accordance with the Water W'ell Construction Rules. A well plugging repon must be completed and submitted to the Division of Water Resources willin 60 days of plugging.

7) Tho owner shall mark the well in a conspicuous place with well permit number and name of aquifer as appropriate, and shall take necessary means and procautions to preserve these markings.

8) This well must be constructed by or under the supervision of a licensed well driller or other authorized individual according to the Water Well Construction Rules.

8) A well completion report including lithologic log must be submitted by the individual authorized to construct the well. For non-standard construction the report must include an as-buith drawing showing detalls such as depth, casing, perforated zones, and a description of the grouting type and interval. This well is known as RU.A.

10) This well shall be constructed not moro than 200 feet from the location specified on this permit

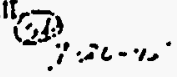

\section{APPROVED SGA}

Roreipt ro. 03863470

\section{DIVISION COPY}

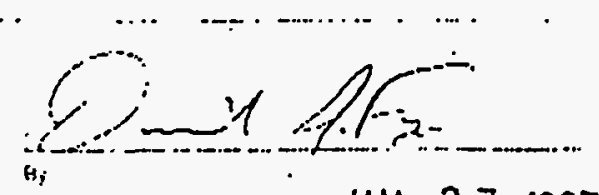

EXPIRATION DATE JUL. 271997 
WELL PERMT NUMBER

DIV. 5 CNTY. 23 WD

wo

188868

Lol: Blook: Filling: Subdiv:

\author{
US DEPT OF ENERGY \\ \%ROXANNE DANZ \\ BOX 98518 \\ LAS VEGAS NV 89193.8518
}

(702)295-7723

PERMIT TO CONSTRUCT A WEU

\section{APPROVED WELL LOCATION GARFIELD COUNTY

NW $1 / 4$ SW $1 / 4$ Section 25
TwP $7 S$ RANGE $.95 \mathrm{~W}$ 6th P.M.

DISTANCES FROM SECTION LINES

$2200 \mathrm{Ft}$. from South Soction Line

$4310 \mathrm{Ft}$ from East Section Line

ISSUANCE OF THIS PERMIT DOES NNOT CONFER A WATER RIGHT CONOTIONS OF APPROVAL

1) This well shall be used in such a way as to cause ro material injury to existing water rights. The issuance of the permit does not assure the applicant that no injuny. will occur to anothor vosted water right or preclude another owner of a vested water right from seeking reliel in a clvil court action.

2) The construction of thls woll shall bo in compllance with the Water Well Construction Rules 2 CCR 402-2, unless approval of a varlance has beon grantod by the State Board of Examiners of Water Well Construction and Pump Installation Contractors in accordance will Rule 18.

3) Approved pursuant to CRS 37.92-602(3)(b)(1) for uses as described in CRS 37-92.602(1)(n). Use of this well is limted to montoring water lovols and/or water quality sampling.

4) This well must be equipped vith a locking cap or seal to prevent woll contamination or possible hazards as an opon well. The woll must be kept locked at all times except during sampling or measuring.

.5) Records of water level moasuromonts and water quality analyses shall be maintainod by the well owrier and submitted to the Divislon of Water Resources upon request.

6) Upon conclusion of the monitoring program the well owner shall plug this well in accordance with the Water Well Construction Rules. A well plugging report must bo completed and submilted to the Division of Water Resources within 60 days of plugging.

7) The owner shall mark the well in a conspicuous place with well permit number and name of acquifer as appropriate. and shall take necessary means and precautions to preserve these markings.

8) This well must be constructed by or under the supervision of a licensed well driller or other authorized individual according to the Water Well Construction Rules.

9) A well completion report including lithologle log must be submilted by the individual authorized to construct the well. For non-standard construction the report must include an as-built drawing showing details such as depth, casihg, perforated.zones, and a descrlptlon of the grouting type and interval. This well is known as RU-5.

10) This well shall be constructod not more than 200 feet from the location specified on this pernit. (if)

\section{DIVISION COBY}

APPROVED
SGA

Receip: 1!o. 0.386347E

DATE ISEUED

JU!. 271995

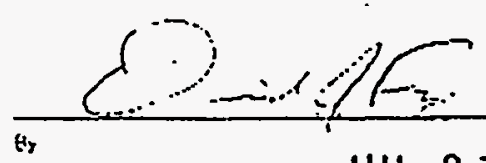

FXPIRATION DATF JUL 27 19E: 
Form No. - OFFICE OF THE STATE ENGINEER

.. GWS.25 COLORADO DIVISION OF WATER RESOURCES

B18 Centonnial Blug.. 1313 Shorman St. Dorivor. Colorado 80203

(303) $800-3581$

US DEPT OF ENERGY

\%ROXANNE DANZ

BOX 98518

LAS VEGAS NV 89193.8518

(702) 295.7723

PERMIT TO CONSTRUCT A WEL
WEL PERMT NUMBER

DIV. 5 CNTY. 23

Wo

45

$45^{\circ}$

DES. BASIN

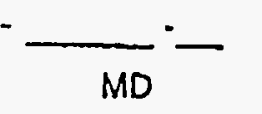

Lot: Block: Filing: Subdiv:

ISSUANCE OF THIS PERMIT DOES NOT CONFER A WATER RIGHT

\section{CONDTTONS OF APPROVAL}

1) This woll shall be used in such a way as to cause no material injury to existing water rlghts. The issuance of the permit does not assure the applicant that no injury will occur to another vestod water right or preclude anothe owner of a vostod water right from seeking reliel in a clvil court action.

2) The construction of this well shall be in compliance with the Water Well Construction Rules 2 CCF 402-2, uniess approval of a variance has been granted by the State Board of Examiners of Watcr Well Construction and Pumf Installation Contractors in accordance with Rule 18.

3) Approved pursuant to CRS 37-92-602(3)(b)(1) for uses as described in CRS 37-92-602(i)(f). Use of this well it limited to monitoring water levels and/or water quality sampling.

4) This well must be equipped with a locking cap or seal to prevent well contamination or possible hazards as ar open well. The well nust be kept locked at all times except during sampling or measuring.

5) Records of water level measurements and water quality analyses shall be maintained by tho well ownor ank submittod to the Division of Water Resources upon request.

6) Upon concluslon of tho monitoring program the well owner shall plug this well in accordance with the Water Wel Construction Rules. A well plugging report must be completed and submitted to the Division of Wator Resource! within 60 days of plugging.

7) The owner shall mark the well In a conspicuous place with well permit number and name of aquiler as approprlate and shall take necossary moans and precautions to preserve these markings.

8) This well must be constructed by or under the supervlsion of a llcensed well driller or other authorized individua according to the Water Well Construction Rules.

9) A well completion report including lithologic log must be submitted by the individual authorized to construct thi well. For non-standard construction the report must include an as-built drawing showing details such as dopth casing. pertorated zones, and a description of the grouting type and interval. This well is known as RU-6.

10) This well shall be constructed not more than 200 feet from the location specitied on this permit

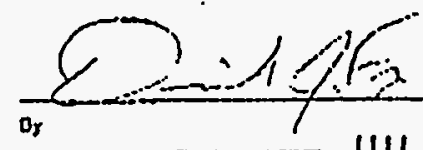


Forn! No. OFFICE OF THE STATE ENGINEER

.. GWS.25 COLORADO DIVISION OF WATER RESOURCES

818 Contcrinital Bldo., 1313 Sherman St. Donvor. Colorado 80203

(.303) $B 56.3501$

LIC

APPLICANT

\author{
US DEPT OF ENERGY \\ \%ROXANNE DANZ \\ BOX 98518 \\ - LAS VEkAS NV 83193.8513
}

(702)295-7723

PERMIT TO CONSTRUCT A WELL

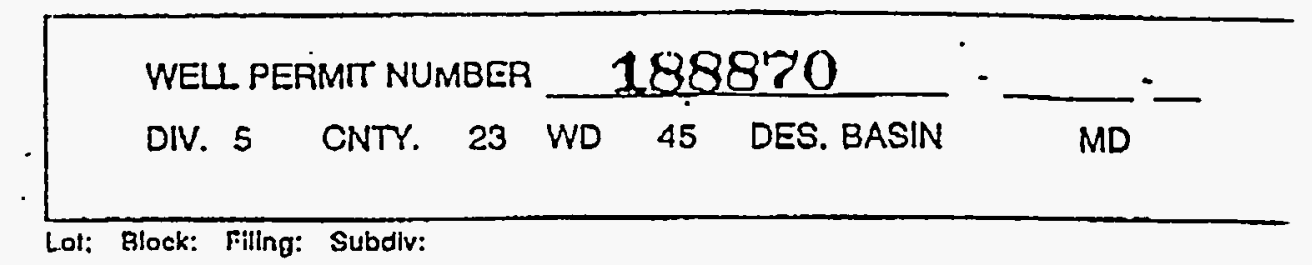

APPROVED WELL LOCATION

GARFIELD COUNTY

NW $1 / 4 \quad$ SW $1 / 4$ Section 25
TWP 75

DISTANCES FROM SECTION LINES

$2130 \mathrm{Ft}$. from South Seclion Line

$4310 \mathrm{Ft}$ from East Soction Lino

ISSUANCE OF THIS PERMIT DOES NOT CONFER A WATER RIGHT

CONDIIONS OF APPROVAL

1) This well shall be used in such a way as to cause no matorlal Injury to existing wator rights. The issuance of tho permit does not assure the applicant that no injury will occur to another vested water right or preclude another owncr-or a vested water right from seeking relief in a civil court action.

2) The construction of this well shall be in compliance with the Wator Well Construction Rules 2 CCR 402-2, unless approval of a variance has been granted by the State Board of Examiners of Water Well Construciion and Pump Installation Contractors in accordance with Rule 18.

3) Approved pursuant to CRS 37-92-602(3)(D)(1) for uses as described In CRS 37-92-602(1)(1). Uso of this well is limited to monitoring water levels and/or water quality sampling.

4) This well must bo equlpped with a locking cap or seal to prevent well contamination or possiblo hazards as an open well. Tho woll must be kept lockod at all times oxcopt during sampling or measuring.

5) Records of water level measurements and water quality analyses shall be maintained by the well owner and submilted to the Division of Water Resources upon request.

6) Upon conclusion of the monitoring program the well owner shall plug this well in accordance with the Water Well Construction Rules. A well pluging report must be completed and submitled to the Division of Water Resources within 60 days of plugging.

7) The owner shall mark the well in a conspicuous place with well permit number and name of aquiler as appropriate. and shall take necessary means and precautions to preserve these markings.

8) This well must be constructed by or under the supervislon of a licensed well driller or other authorized individual according to the Water Well Construction Rulos.

9) A well completion repor including lithologic log must be submitted by the individual authorized to construct the woll. For non-standard construction tho roport must includo an as-buill drawing shoving details such as depth, casing, perforated zones, and a description of the grouting typo and interval. This well is known as RU-7.

10) This well shall be constructed not more than 200 feet from the location specified on this permit

\section{DIVISION COEY}

APPROVED
SGA
Receript No. O38G347G


WELL PERMT NUMBER

APPLICANT

DIV.. 5 CNTY. 23

$\frac{188871}{\text { WD } 45 \text { DES. BASIN }}$

Lot: Block: Filling: Subdiv:

\author{
US DEPT OF ENERGY \\ \%ROXANNE DANZ \\ BOX 98518 \\ LAS VEGAS NV $89193-8518$ \\ (702)295.7723
}

PERMIT TO CONSTRUCT A WEU

\section{APPROVED WELL LOCATION \\ GARFIELD COUNTY.}

NW $1 / 4$ SW $1 / 4$ Section 25
$7 S$ RAINGE $95 \mathrm{~W}$ 6th P.M.

DISTANCES FHOM SECTION LINES

$\begin{array}{lll}2440 \text { Ft. from } & \text { South Section Line } \\ 4180 \text { Ft. from } & \text { East Section Line }\end{array}$

\section{ISSUANCE OF THIS PERMIT DOES NOT CONFER A WIATER RIGHT CONDTIONS OF APPROVAL}

1) This well shall be used in such a way as to cause no material injury to existing water rights. The issuance of the permit does not assuro the applicant that no injury will occur to another vested water right or procludo anotho owner of a yested wator right from seeking relief in a civil court action.

2) The construction of this well sinall be in compliance with the Water Well Constiuction fules 2 CCR 402-2, unlass approval of a variance has been granted by the State Board of Examiners of Watcr Wiell Construction and Pumf Installation Contraciors in accordance with Rule 18.

3) Approved pursuarit to CRS $37.92-602(3)(b)(1)$ lor uses as described in CRS 37-92-602(1)(n). Uso of this well ke limited to monitoring waler lovols. and/or water qualiny sampling.

4) This well must be equipped with a locking cap.or seal to prevent well contamination or possible hazards as ar open well. The well must be kept locked at all times except during sampling or measuring.

5) Records of water lovel measurements and water quality analyses shall be maintained by the well ownor ane submitted to the Division of Water Resources upon request.

6) Upon conclusion of the monitoring program the well owner sinall plug this weil in accordance vilth tho Water Wel Construction Rules. A well plugging report must be completed and submitted to the Division of Water Rosources within 60 days of plugging.

7) The owner shall mark the well in a.conspicuous place with well permit number and name of aquifer as appropriate and shall take necessary meanis and precautions to preserve these markings.

8) This well must be constructed by or under the supervision of a licensed well driller or other authorized inclividua according to the Water Well Construction Rules.

9) A well completion repor including lithologic log.must be submitted by the individual authorized to construct the well. For non-standard construction the repont must Include an as-built drawing showing details such as depth casing. perforated zonos, and a doscription of the groutlng type and interval. This well is known as RU-8.

10) This well shall bo constructed not moro than 200 foot from the location specifled on this permit.

$$
69-26 \cdot 5
$$

APPROVED
SGA


Water Well Construction Rules;

Eflective Date April 1, 1995

5.2.32 "Watertight" means a condition which does not allow the entrance, passage or flow of water under normal operating conditions.

5.2.33 "Well Owner" means any person or his agent who holds the title or other rights of property in a well:

5.2.34 "Woll Pit" means a structure for the underground installation of equipment and piping. If the well terminates in the pit, the structure shall be deemed to be a vault.

5.2.35 "Well Vault" means an underground structure in which the well casing terminates below ground surface. A vault may include the installation of additional equipment and piping.

5.2.36 "Well Yield Test" means a test of a well conducted to determine a stabilized drawdown and production rate of a well.

5.3 Other Definitions - All other words used herein shall be given their usual customary and accepted meaning. Terms that were not defined in this Rule which are defined in the statutes or other rules of the State Engineer shall use the meaning given therein. All words of a technical nature specific to the water well industry shall be given the meaning which is generally accepted in the said water wall industry.

\section{RULE 6 GENERAL RULES}

6.1 Permit Requirement - A permit issued by the State Engineer is required prior to constructing a new or replacement well, prior to changing the producing interval of an existing wall or prior to installing the initial pumping system or a pumping system having a sustained production rate in excess of the permitted production rate.

6.1.1 It is the responsibility of all persons authorized to construct wells or install pumping equipment to ensure that a valid permit issued by the State Engineer exists prior to and during all work.performed to construct or modify a well. A copy of the permit, verbal approval number or a copy of the notice provided to the State Engineer shall be available at the drilling site

6.1.2 All well construction, repair of an existing well, or installation or replacement of a pump shall comply with the conditions of approval on the valid well permit or the verbal approvat. The work shall be completed prior to the expiration of the permit.

6.2 Authorized Well Construction or Pump Installatlon Contrsctor - Well coristruction, repair, modification or plugging and sealing or pump installation, repair, or modification shall be performed only by a contractor or a direct employes of the contractor or by a person who is under supervision of an individual having a valid license issued by the Stato Board of Examiners of Water Well and Pump Installation Contractors unless exempt under provisions of Rule 7 or Section $37.97-206(3)$, C.R.S.

6.3<smiles>[AlH2]</smiles>
Notice of Intent to Construct - Prior to beginning construction of a well, a monitoring and - -obstrvation hole, or a test hole, the licensed water well contractor or the authorized individual shall notify the State Engineer of their intent to construct as shown below. Such notice is not 
Water Wall Construction Rules;

Effective Date April 1, 1985

required for test holes which are not intended to be constructed through a confining layer between aquifers.

a. for wells where a permit has been-issued by the State Engineer, such notice shall be submitted not less than three (3) nor more than ten (10) working days prior to the anticipated date of construction. This notice shall be submitted on a form provided by the State Engineer and shall be valid for a period of fourteen (14) calendar days from the anticipated construction date. In the event that a construction contractor has entered into an agreement to construct a well less than this minimum three (3) day notice requirement, such notice may be given by facsimile transmission. After six (6) months from the effective date of these rules, the Board may evaluate and reconsider the impacts and effectiveness of this notice requirement and shall have the authority to suspend this rule by taking formal action at an official Board meeting; or

b. for test holes which will penetrate though a confining layer beiween aquifers and for monitoring and observation holes the notice shall be submitted in writing at least three (3) days prior to construction, and the construction of the excavation must be completed within 90 days from the date of notice to the. State Engineer. This monitoring or test hole notice shall contain the following information as a minimum (Table 1 summarizes when notice to the State Engineer is required):

Landowner's name; structure owner's name; rame of the water well contractor or authorized individual: approximate date of construction: location by $1 / 4-1 / 4$, section, township and range; number and type of holes to be constructed; estimated total depths: and purpose or intended use of the holes.

6.4 Compliance with Regulations - Construction of all wells shall, as a minimum, comply with the standards in these Rules. In the case where federal, state, county, municipal or local government laws, regulations or codes are more stringent than these Rules or contain standards not covered by these Rules, then the contractor shall comply with those standards.

6.5. Products Containing Toxic Materlals - Products such as solder and fluxes containing more than two tenths $(0.2)$ per cent lead, and materials, such as pipes and fittings containing more than eight (8.0) per cent lead and all mercury are prohibited from being used in wells and holes.

6.6 Disposal of Fluids Resulting from Well Construction, Development and Disinfection Fluids resulting from well construction, development or disinfection shall not be discharged into the waters of the state without first obtaining a permit pursuant to the Colorado Discharge Permit System (CDPS). Fluid disposal by land application must not flow into or have the potential to sllow into surface waters and must not impact aquatic life or ground water. Fluid wastes may be disposed of by other proper means such as off site transport for treatment and final disposal, evaporation ponós, or pumping to a sanitary sewer system with permission.

6.7 Directional Drilling - Prior approval from the State Engineer is required if the proposed well will be deflected more than 200 feet horizontally from its surface location.

6.8 Water Used for Well Construction and Stimulation. All water used during the construstion, development and stimulation of a well shall be obtained from an approved public supply. if water is not readily available from such a public supply, the water may be obtained 
Appendix C

Pond Draining and Construction Dewatering Analytical Results 


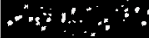

to: Ray Ireary, IT

faxil: $\quad 793-5222$

re: CDPS Eermit COG-310084 Reported Violations

data: Soptember 24, 1996

pagas: 1 , induding this cover shest.

Kevin Leary, at USDOE, requested I send you this fax regerding seported violations for the sbove-referenced permit. At this time, the Division does not intend to pursue formal enforcement action againot tho permittco for tho violations roported on Discharge. Monitoring Reports submitted to the Divislon relative to this permit.

If you have any questions, you may contact me at the number listed bolow.

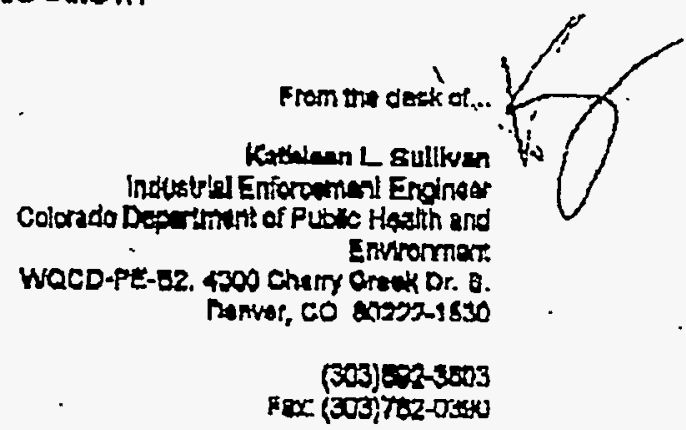


Table C-1

Pond Draining and Construction Dewatering Analytical Results

\begin{tabular}{|c|c|c|c|c|c|c|c|c|c|}
\hline & & \multicolumn{8}{|c|}{ Pond Dewaiering Samples } \\
\hline IT Corp ID\# & Permit Criterion & RU00100 I & & RU00102 & & RU00115 & & RU00115 & \\
\hline Date Collected & & $8 / 2 / 95$ & & $8 / 7 / 95$ & & $8 / 11 / 95$ & & $8 / 11 / 95$ & \\
\hline Sample Location & & Pond Water & & Pond Water & & Pond Water & & Reanalysis & \\
\hline & & \begin{tabular}{|l|} 
Conc. \\
\end{tabular} & $\mathbf{Q}$ & Conc. & Q & Conc. & $\bar{Q}$ & Conc. & a \\
\hline METALS: $:::::: \ldots \ldots: 2: \%$ & Oig/lla: & Uig/l: & $\therefore$ & $\because u g / \Omega$ & $\because$ & $\because \mu g / \mathrm{L} \because:$ & $\because \because$ & $\mu g / L$ & \\
\hline Chromium & 50 & 3.3 & $U$ & 4.4 & B & 131 & & 35.9 & \\
\hline Iron & 1000 & 201 & & 113 & & 1660 & & 84.1 & \\
\hline Dissolved Lead ${ }^{a}$ & 31 & 2.0 & $\mathbf{u}$ & 2.0 & $\mathrm{U}$ & 7.6 & & na & \\
\hline Mercury & 2 & 0.20 & $\bar{U}$ & 0.20 & $\mathrm{U}$ & 0.20 & $\bar{U}$ & na & \\
\hline Zinc & 10 & 6.8 & & 4.0 & & 20.2 & & na & \\
\hline ORGANICS: & Hgn & $\because \mu g h$ & $\because \because$ & oign/ & $\because$ & Hgin $\because$ & $\because$ & $\because \therefore \lg / 1: \vdots$ & $:$ \\
\hline Benzene & 1 & 1 & $\mathrm{U}$ & 1 & U & 1 & $\mathrm{U}$ & na & \\
\hline Toluene & NS & 5 & $\bar{U}$ & 5 & U & 5 & $\bar{U}$ & na & \\
\hline Ethyibenzene & NS & 5 & $\underline{U}$ & 5 & $\mathrm{U}$ & 3 & $\bar{J}$ & na & \\
\hline Total Xylene & NS & 5 & $\mathrm{U}$ & 5 & $\mathrm{U}$ & 6 & $\mathrm{~J}$ & na & \\
\hline Organic Toxic Pollutants & NS & & & & & ND* & & na & \\
\hline 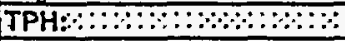 & $\therefore m g / n$ & $\therefore: \mathrm{mg} / \mathrm{i} \because \mathrm{O}$ & $\because \therefore$ & $\because$ mg/l: & $\because$ & $\therefore: m g / 6$ & $\therefore \because$ & $\therefore:$ mgR:: & \\
\hline Nonspecific & 10 & 5.0 & UJ & 0.5 & $\bar{U}$ & 6.46 & & na & \\
\hline Diesel & 10 & $\mathrm{na}$ & & na & & na & & na & \\
\hline INORGANICS: $\because,:: \cdots,:$, & mg $/$ L $\because$ & $\mathrm{mg} \Omega \because \because$ & $\because$ & $\because \mathrm{mg} / \mathrm{L} \because$ & & $\because$ mgn $\because$ & & $\therefore \operatorname{mg} / 2$. & \\
\hline Total Dissolved Solids & NS & 380 & & 393 & & 380 & & na & \\
\hline Total Suspended Solids & $30 / 45^{c}$ & 4.0 & & 3.0 & & 49.0 & & na & \\
\hline $\mathrm{pH}$ & $6.5-9.0$ & 8.2 & & 8.1 & & 7.8 & & na & \\
\hline
\end{tabular}

\begin{tabular}{|c|c|c|c|c|c|c|c|c|c|}
\hline & & & & instruction & De & watering San & nple & & \\
\hline IT Corp ID\# & Permit Criterion & RU-CDW-01 & & RU-CDW-03 & & RU-CDW-05 & & RU-CDW-06 & \\
\hline Date Collected & & $9 / 15 / 95$ & & $9 / 15 / 95$ & & $9 / 27 / 95$ & & $10 / 5 / 95$ & \\
\hline Sample Location & & Pond Water & & Pond Water & & Pond Water & & Pond Water & \\
\hline & & Conc. & $\mathbf{Q}$ & Conc. & & Conc. & & Conc. & \\
\hline METALS $\because \cdots$ & $\Leftrightarrow \cdots$ & $\because \mu g / \measuredangle$ & $\because$ & $\because \mu g h \Leftrightarrow$ & & 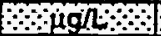 & & $\because \mu g / 6$ & $\therefore$ \\
\hline Chromium & 50 & na & & na & & 10 & $\bar{U}$ & 13 & \\
\hline Iron & 1000 & na & & $n a$ & & 660 & & 4100 & \\
\hline Dissolved Lead ${ }^{\mathrm{a}}$ & 31 & na & & na & & 31 & $\mathbf{U}$ & 31 & $\mathrm{u}$ \\
\hline Mercury & 2 & na & & na & & 0.20 & $\mathrm{U}$ & na & \\
\hline Zinc & 10 & na & & na & & 20 & $U$ & 28 & \\
\hline ORGANICS:b:::::a & oligh & Gigh & $\because$ & $\because i g h$ & $\therefore$ & iqg & $\Leftrightarrow$ & $\theta i g h$ & $::$ \\
\hline Benzene & 1 & 5 & $\underline{U}$ & 2 & $\mathrm{U}$ & 1.0 & $\mathrm{U}$ & 5.0 & $\mathrm{U}$ \\
\hline Toluene & NS & na & & na & & 0.40 & J & 0.18 & $\mathrm{~J}$ \\
\hline Ethylbenzene & NS & na & & $\mathrm{na}$ & & 0.14 . & $\mathrm{J}$ & 0.18 & $\mathrm{~J}$ \\
\hline Total Xylene ' & NS & na & & na & & 0.80 & $\sqrt{J}$ & 25 & U \\
\hline Organic Toxic Pollutants & NS & na & & na & & $\mathrm{ND}^{*}$ & & & \\
\hline TPH: $\cdots \ldots \ldots \ldots \ldots \ldots \ldots$ & $\therefore \therefore$ mig/l & $\therefore \mathrm{mg} / \mathrm{l} \theta$ & & $\because \mathrm{mg} / \mathrm{L}$ & & $\because$ mg/l $\because$ & $\because$ & $\mathrm{mg} / \mathrm{l}$ & $\because$ \\
\hline Nonspecific & 10 & na & & na & & 1.0 & $\mathrm{U}$ & na & \\
\hline Diesel & 10 & $\mathrm{na}$ & & na & & na & & 0.44 & \\
\hline INORGANICS: ::::::::: & $\because \because \mathrm{mg} h \because \cdots \mathrm{a}$ & $\because \mathrm{mg} / \mathrm{n} \because$ & $\because$ & $\because \mathrm{mg} / \mathrm{t} \because \because$ & & $\because$ mgdL $\because$ & $\because$ & $\because$ mgitl $\because$ & $\because:$ \\
\hline Total Dissolved Solids & NS & na & & $\mathrm{na}$ & & 380 & & 570 & \\
\hline Total Suspended Solids & $30 / 45^{c}$ & na & & na & & 14 & & 140 & \\
\hline $\mathrm{pH}$ & $6.5-9.0$ & na & & na & & 7.7 & & 7.5 & J \\
\hline
\end{tabular}

$Q=D$ ata qualifier: $U=$ Compound was analyzed but not detected above the specified limit; $J=$ Reported value is e $\mathrm{mg} \Omega=$ milligrams per liter; $\mu \mathrm{g} \Omega$ = micrograms per liter

$n a=$ not analyzed; $N D^{*}=$ not detected. See Table $\mathrm{C}-2$ for analytical quantitation limits..

NS $=$ not specified

\footnotetext{
a Dissolved Lead analysis required under the discharge permit.

${ }^{b}$ Permit criterion for Total BTEX (benzerie, tolvene, ethylbenzene, and xylenes) $=100$ ugh

${ }^{c} 30 / 45 \mathrm{mg} /$ refers to 30 day average/7 day average
} 
Table C-2

Pond Draining and Construction Dewatering Analytical Results Organic Toxic Pollutants

\begin{tabular}{|c|c|c|c|c|c|}
\hline IT Corp ID\# & Permit Criterion * & RU00115 & & \multicolumn{2}{|l|}{ RU-CDW-05 } \\
\hline Date Collected & & $8 / 11 / 95$ & & & \\
\hline Sample Location & & Pond Water & & Pond Water & \\
\hline & & Conc. & $\mathbf{Q}$ & Conc. & \\
\hline ORGANIES & jg/L & $\mu g / L$ & 3 & $\mu \dot{g} / \mathrm{E}$ & \\
\hline Chloromethane & 10 & .10 & $U$ & NR & \\
\hline \begin{tabular}{|l} 
Vinyl Chloride \\
\end{tabular} & 2 & 2 & $\mathrm{U}$ & 2.0 & U \\
\hline Bromomethane & 10 & 10 & U & $\mathrm{NR}$ & \\
\hline Chloroethane & 10 & 10 & $\mathrm{U}$ & 10 & U \\
\hline Acrolein & 25 & 20 & $\mathrm{U}$ & 25 & $U$ \\
\hline Acrylonitrile & 25 & 20 & $\mathrm{U}$ & 25 & $U$ \\
\hline Methylene Chloride & 10 & 10 & $\mathrm{U}$ & 10 & $\mathrm{U}$ \\
\hline 1,1-Dichloroethene & 5 & 5 & U & 5.0 & $\mathrm{U}$ \\
\hline trans-1,2-Dichloroethene & 5 & 5 & $\mathrm{U}$ & 5.0 & $\bar{U}$ \\
\hline 1,1-Dichloroethane & 5 & 5 & U & 5.0 & $\bar{U}$ \\
\hline Chloroform & 5 & 5 & 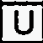 & 5.0 & $U$ \\
\hline 1,2-Dichloroethane & 5 & 5 & $\mathrm{U}$ & 5.0 & U \\
\hline 1,1,1-Trichloroethane & 5 & 5 & $U$ & 5.0 & U \\
\hline Carbon Tetrachloride & 5 & 5 & $U$ & 5.0 & $\mathrm{U}$ \\
\hline Trichloroethene & 5 & 5 & $U$ & 5.0 & $U$ \\
\hline 1,2-Dichloropropane & 5 & 5 & U & 5.0 & $U$ \\
\hline Benzene & 5 & 1 & $\mathrm{U}$ & 1.0 & U \\
\hline Bromodichloromethane & 5 & 5 & $\mathrm{U}$ & 5.0 & U \\
\hline 2-Chloroethylvinyl ether & 10 & 20 & UJ & 10 & $\mathrm{U}$ \\
\hline trans-1,3-Dichloropropene & 5 & 5 & $\mathrm{U}$ & 5.0 & (U) \\
\hline cis-1,3-Dichloropropene & 5 & 5 & $\mathrm{U}$ & 5.0 & $\bar{U}$ \\
\hline 1,1,2-Trichloroethane & .5 & 5 & $U$ & 5.0 & $U$ \\
\hline Chlorodibromomethane & 5 & 5 & $\mathrm{U}$ & 5.0 & U \\
\hline Toluene & 5 & 5 & $\mathrm{U}$ & 0.40 & $\mathrm{~J}$ \\
\hline Tetrachloroethene & 5 & 5 & $U$ & 5.0 & U \\
\hline Chlorobenzene & 5 & 5 & $\mathrm{U}$ & 5.0 & $U$ \\
\hline Ethylbenzene & 5 & 3 & $\mathrm{~J}$ & 0.14 & $\mathrm{~J}$ \\
\hline Total Xylene & NS & 6 & $J$ & 0.80 & $J$ \\
\hline Bromoform & 5 & 5 & UJ & 5.0 & $\bar{U}$ \\
\hline 1,1,2,2-Tetrachloroethane & 5 & 5 & $\mathrm{U}$ & 5.0 & U \\
\hline
\end{tabular}

$Q=$ Data qualifier: $U=$ Compound was analyzed but not detected above the specified limit; $J=$ Reported value is estimated. $\mu g / L=$ micrograms per liter $N R=$ not reported; $N S=$ not specified

- Permit Criterion is a maximum acceptable detection limit. 
Appendix D

Stabilized Sediment Analytical Results 


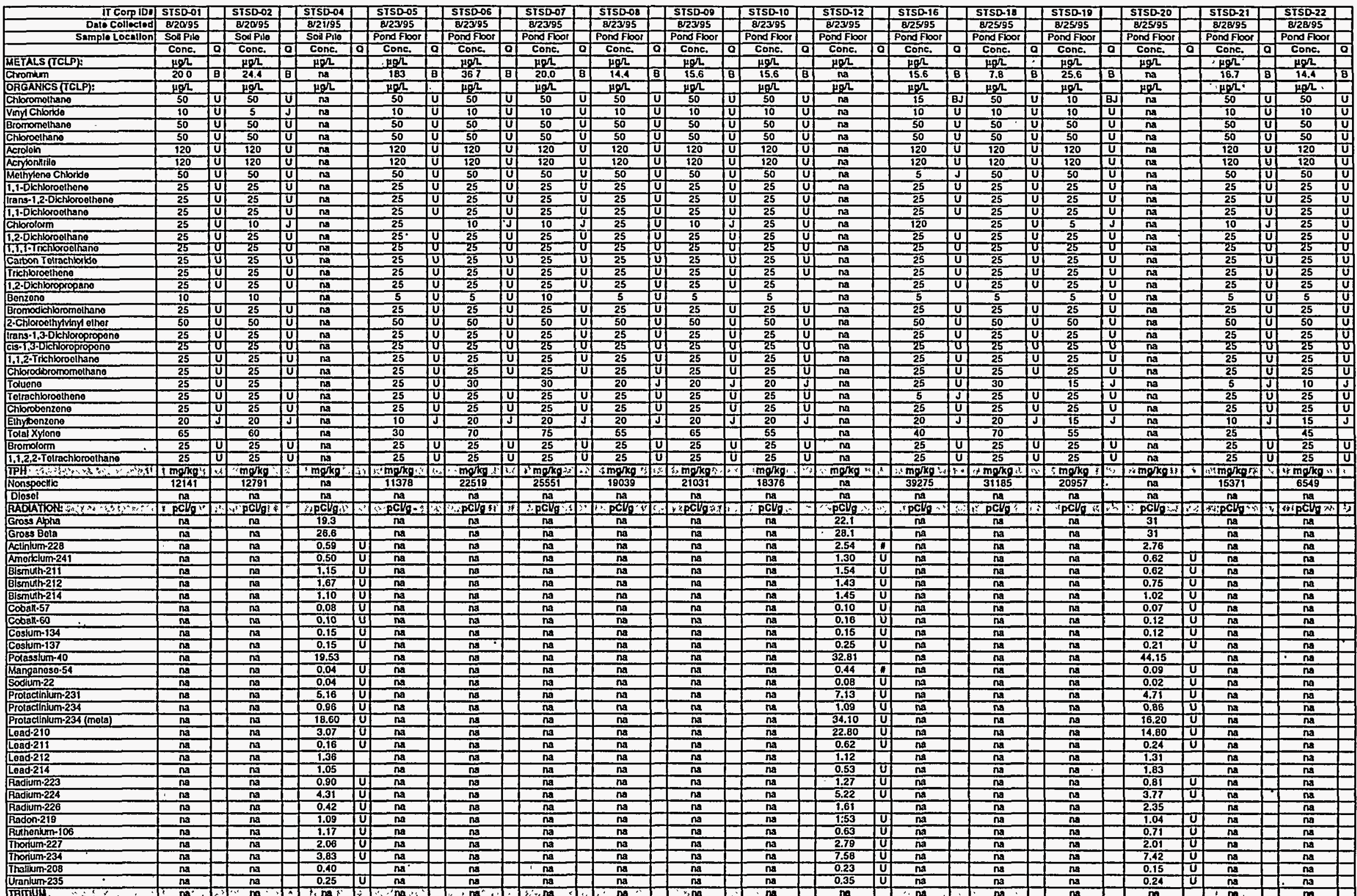




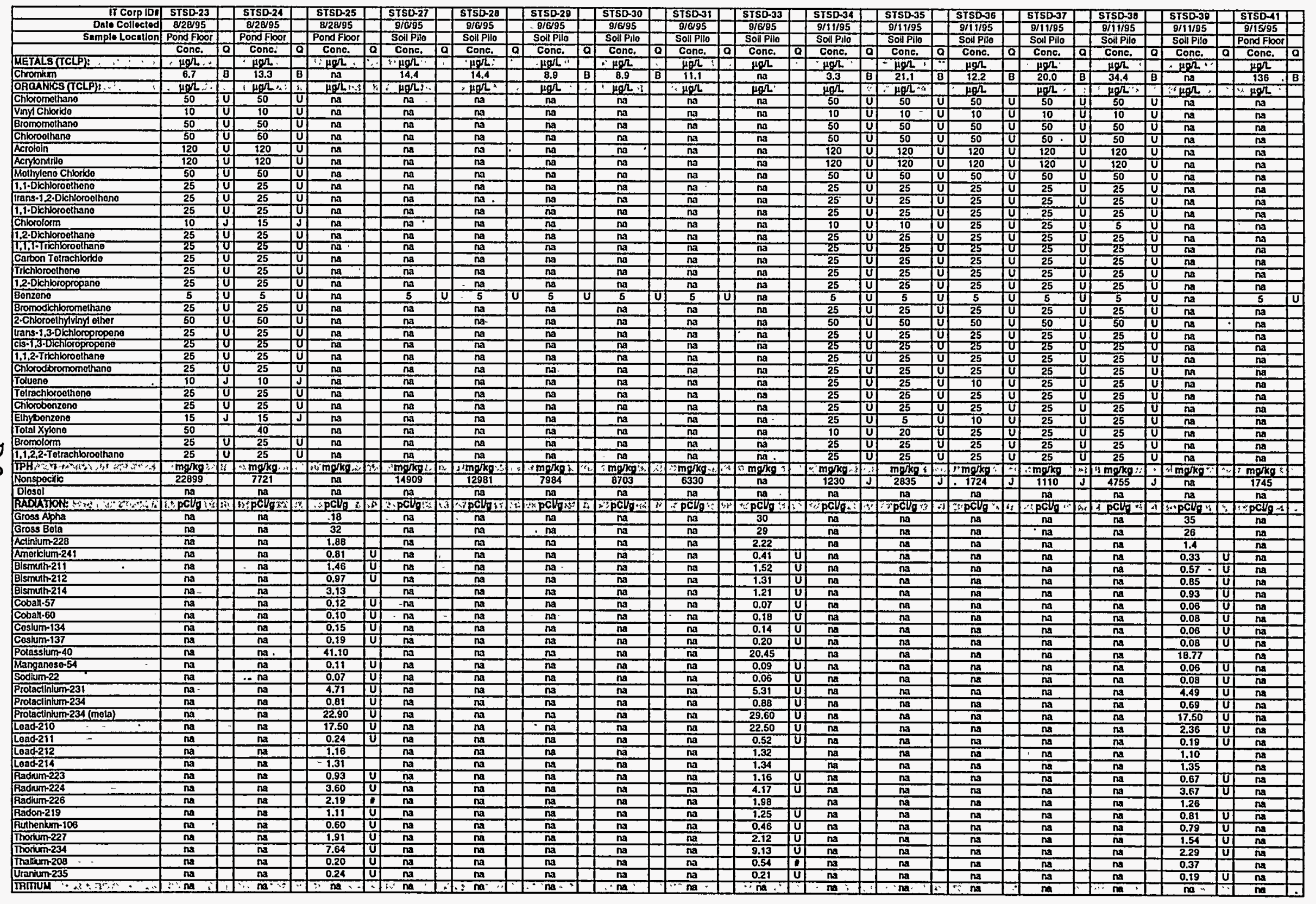




0
0

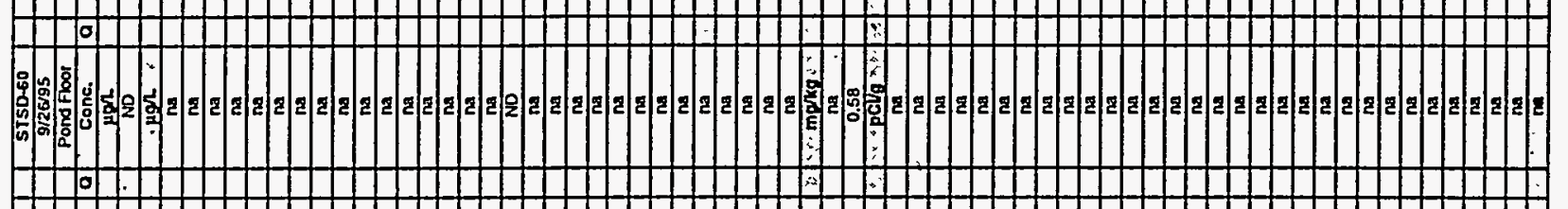

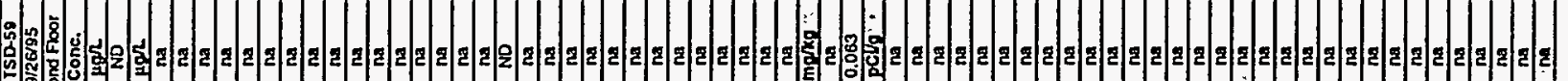

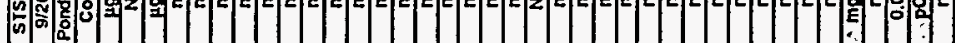

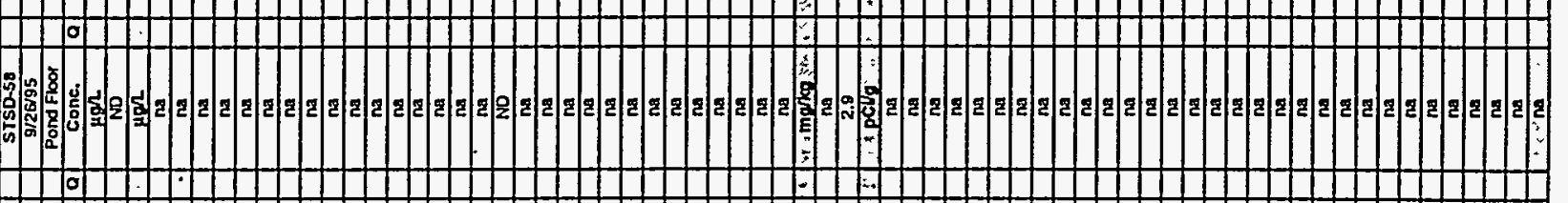

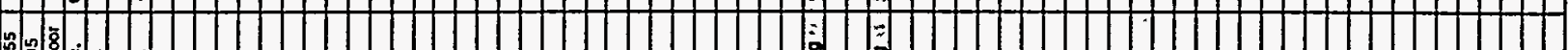

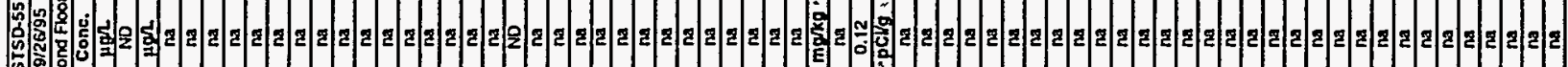

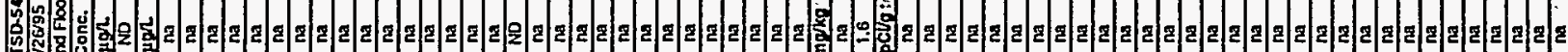

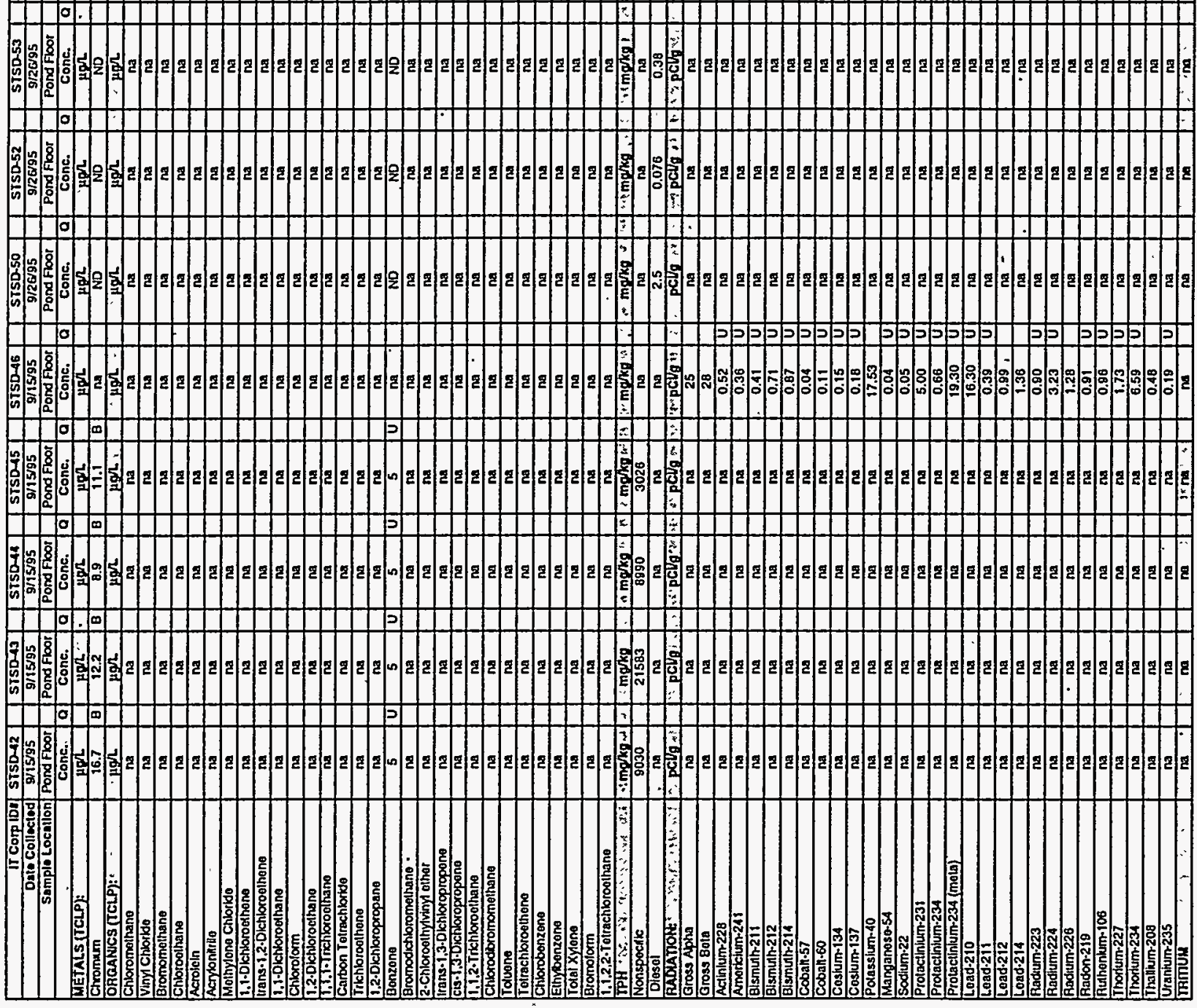




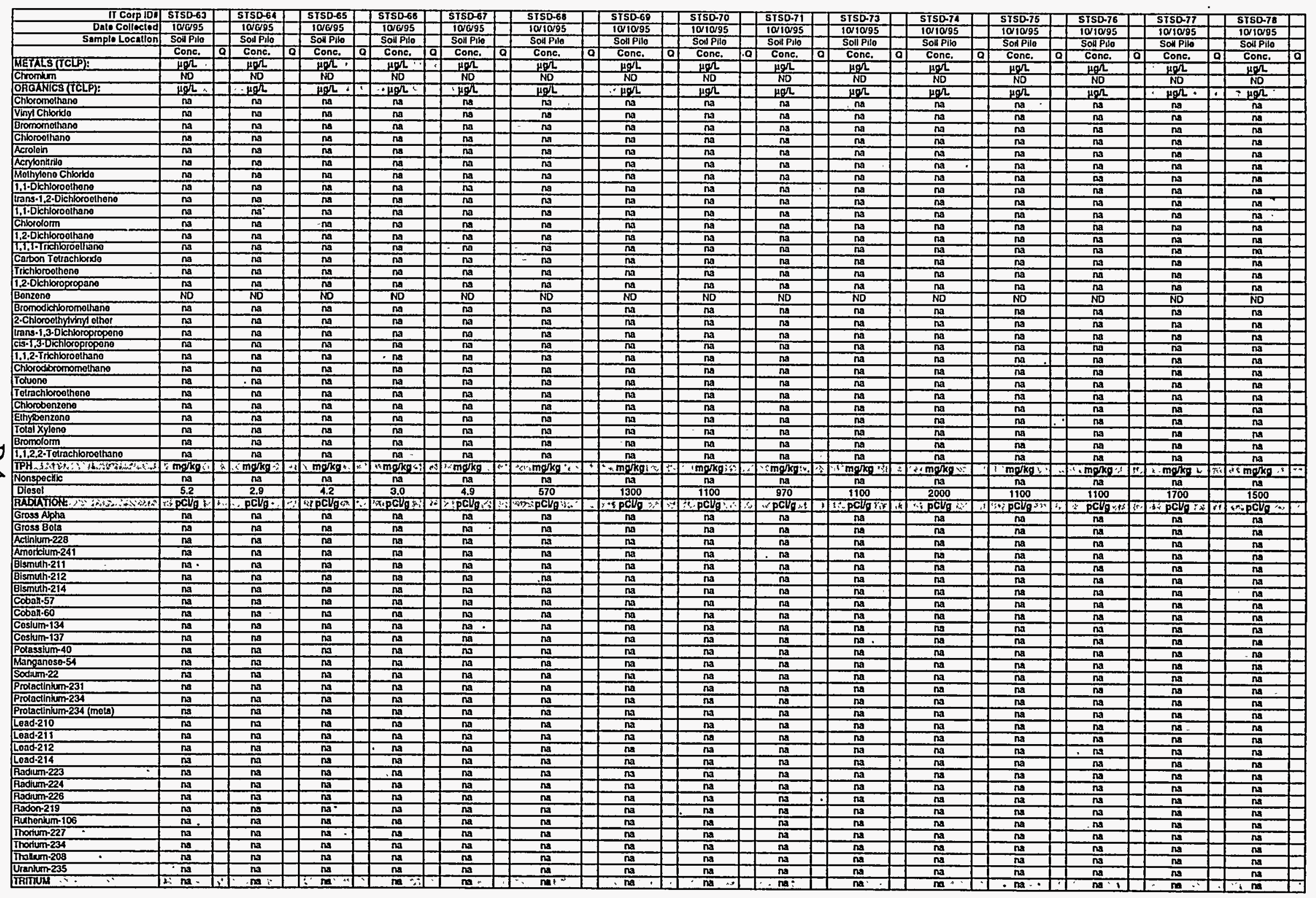




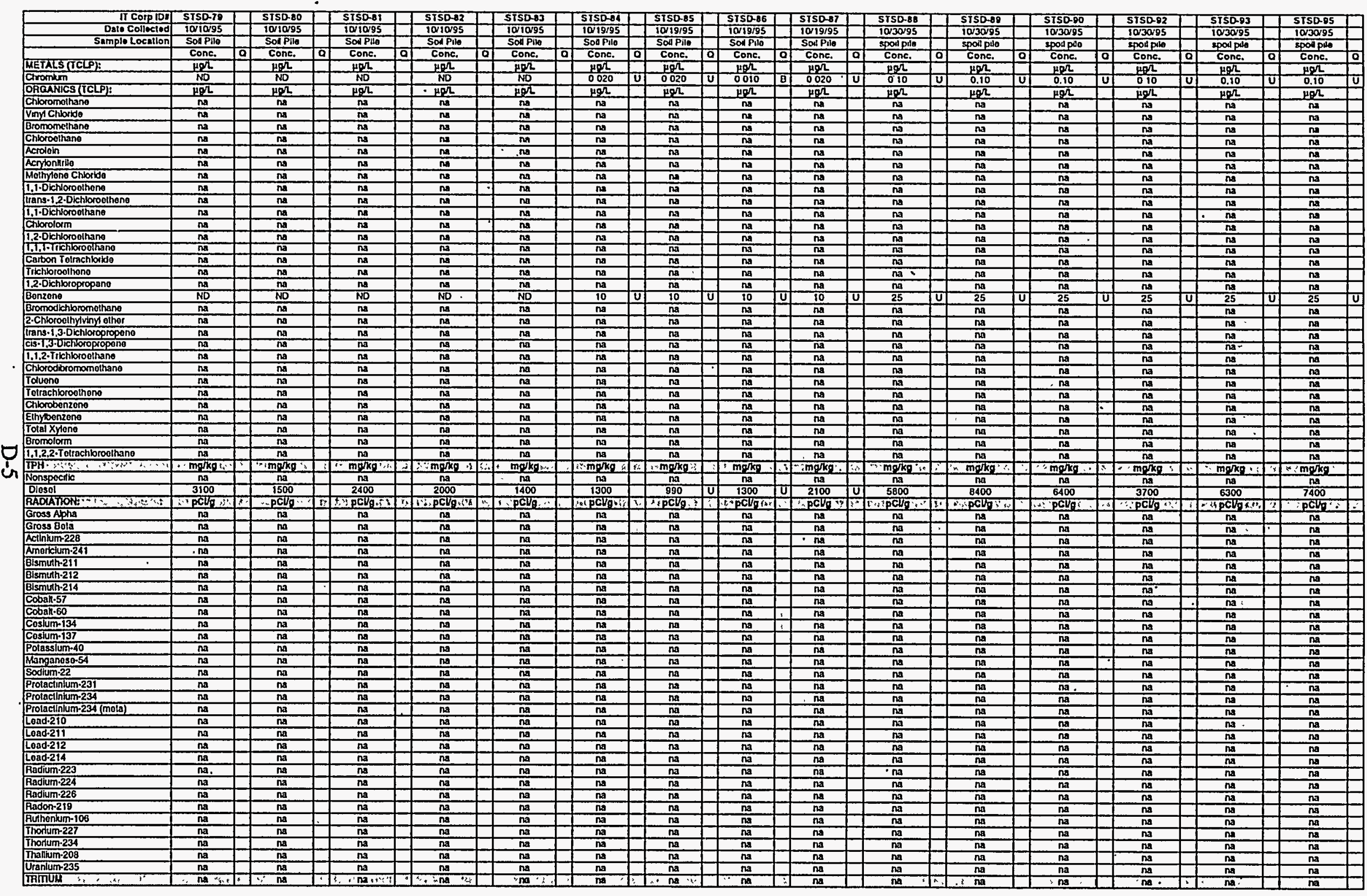




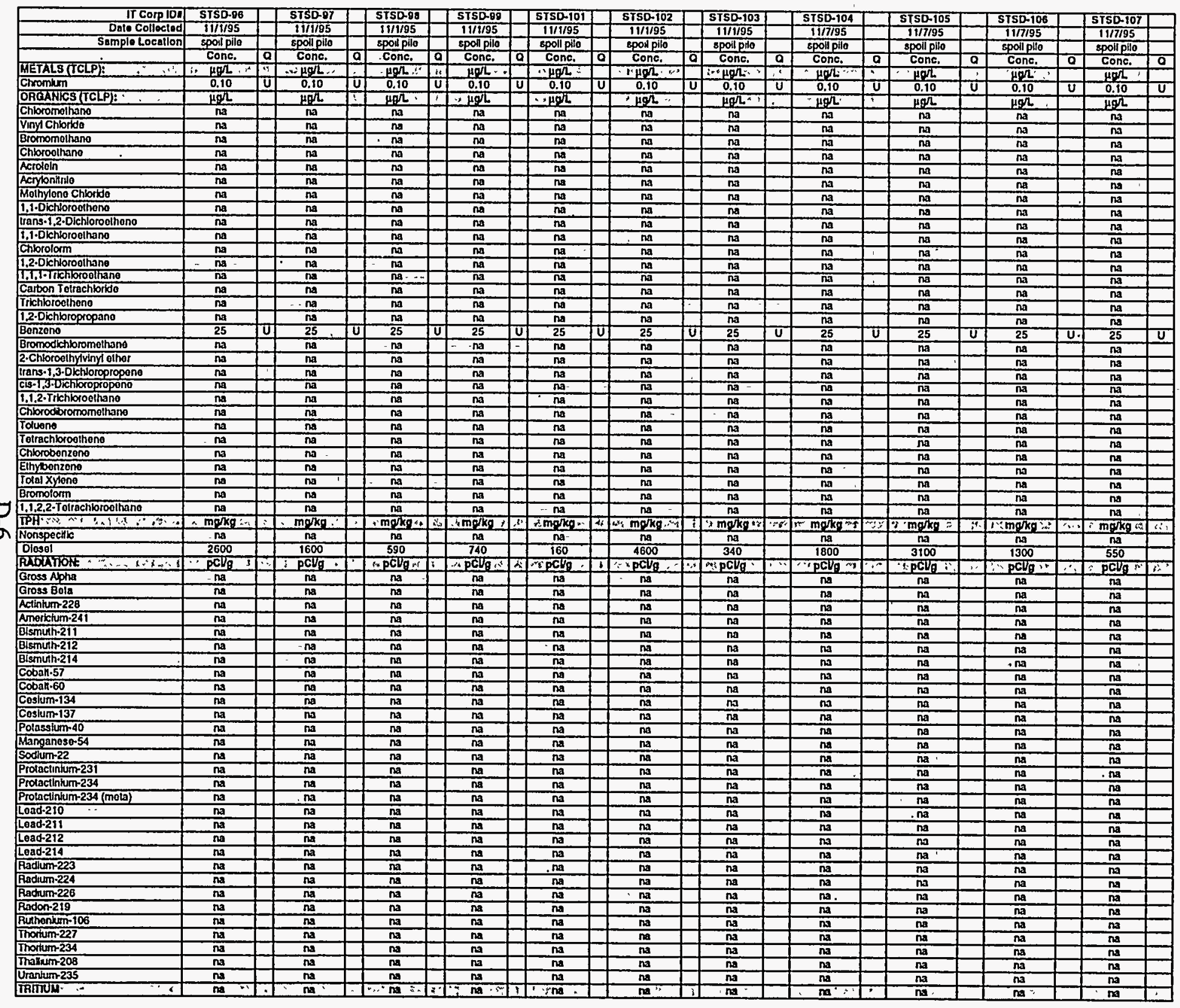




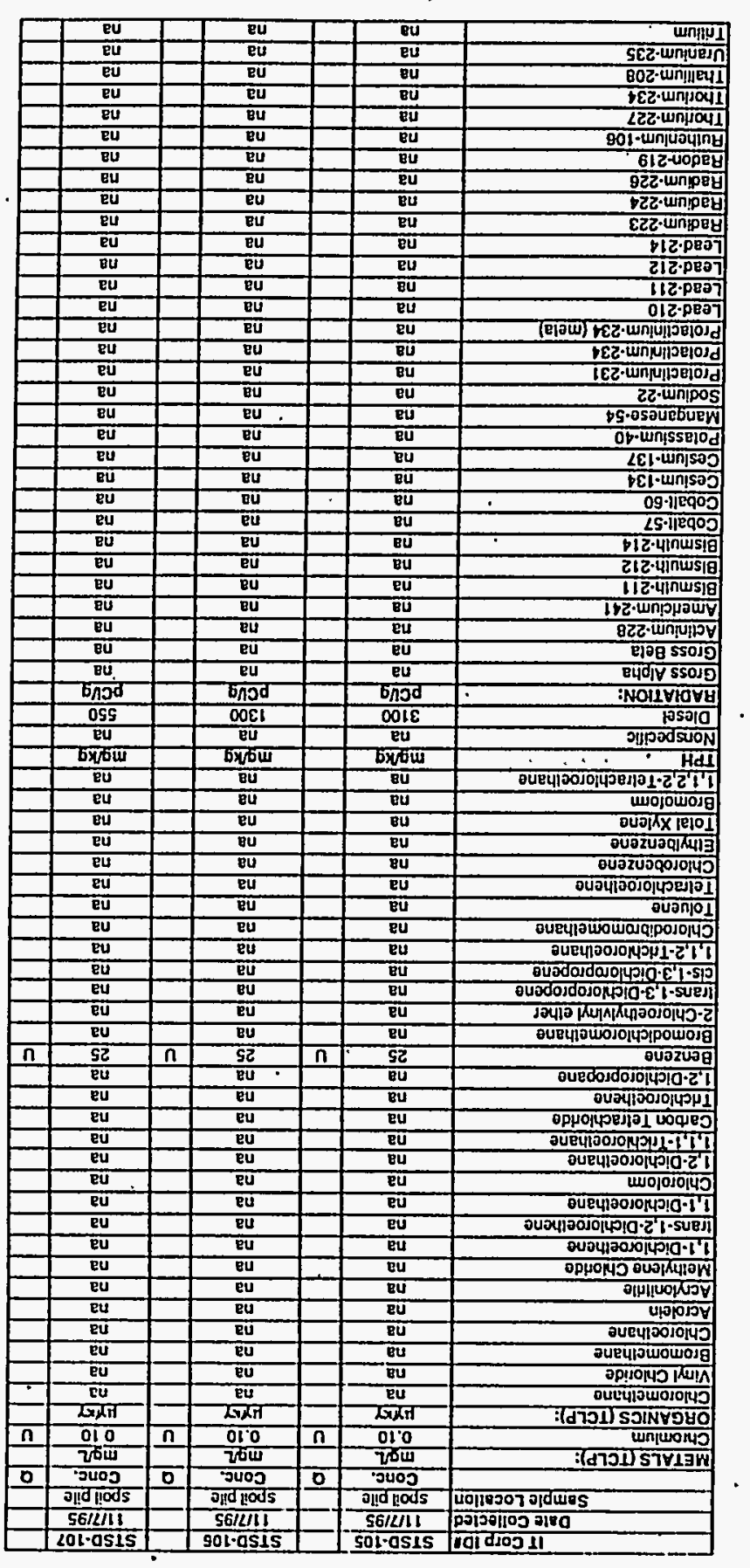

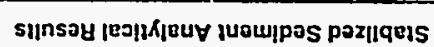


Appendlx D

Stabllzed Sediment Analytical Results

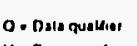

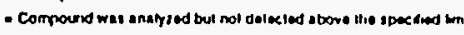

- Reporied value a sermaled

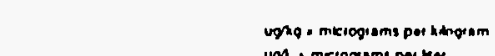

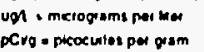

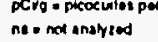

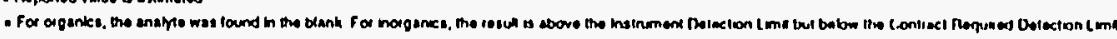

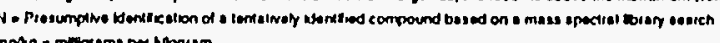

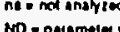

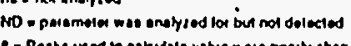

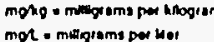

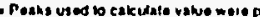

mol $=$ mingrami per her 
Appendix E

Pond Cleanup Verification Analytical Results 
Roy Romer, Gowmox

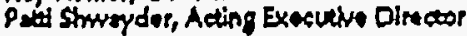

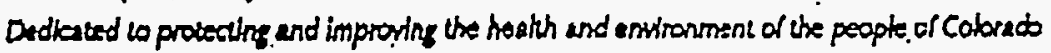

Grand function Retsonal Othe

232 5. Geh SteE, Room 232

Gind function Colorodo 81501-2768

Fax (970) 240-7198

June 7, 1996

Kr. Btophen A. Killington, Direotor

Invironsantal Ramtoration DLvielon

Departwant of Inargy Nevade operations offlco

5.0. Box 98518

- Lak Vegar, Novada' 89193-8518

Rar sulluon pond stto

Daur Xr. MLllingtons

Hr. Keviln Loery of your of:lee has aoked mo to write a latter confirming oux

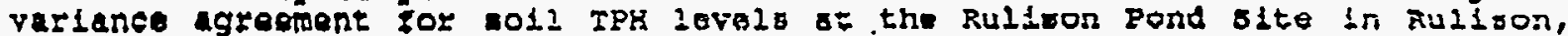
Colorado. The Remodiction Plan groposad attalnment levels of $250 \mathrm{mg} / \mathrm{kg} \mathrm{TP!}$ in soli in the oxouveted aroa. Thie sarget loval was ontublikhed by rovitew of the

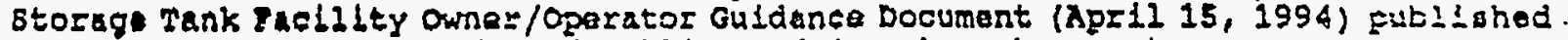
by the colorado Department of Putlic Headth and Environment.

During the remediatlon, it became necobsary to leavo in placo loolatad areas with TPH concentrations in exceas of the proposed attalnment level. A varianco of up to $1000 \mathrm{mg} / \mathrm{kg}$ IPH was agreed to by the colorado Department of public Health

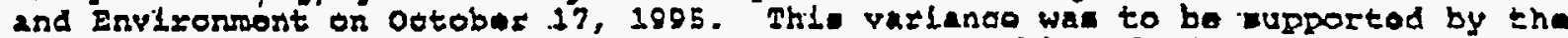
Departmant of Enezgy with a risk asersoment that would ovaluate and document the azake. and artimated volumes being left in place. Additlonaliy, groundwatar monitoring bing conducted quartarly tor a mininum of two years will be utilized to demonstrate the effectivensas of the remodistion.

The Ilsk angerment and documentation hes not yot boun faceivad by our of Ilea. This intortaztion will be reviowed upon recelpt.

If you require, further information regarding the TPH vartance plaade contact mo at $\cdot 970-24 B=7168$.

sinceraly,

(sinic

L

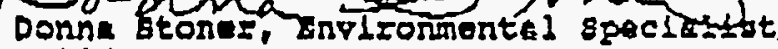

Bolld Fast. Program

Herardour Haterlals and

Mart. Kanagament DLvLELon

ids

cer Kr. Kevln Leary, DOF Kevade Operatlona OEflce

SH OAR RUL IR

rile

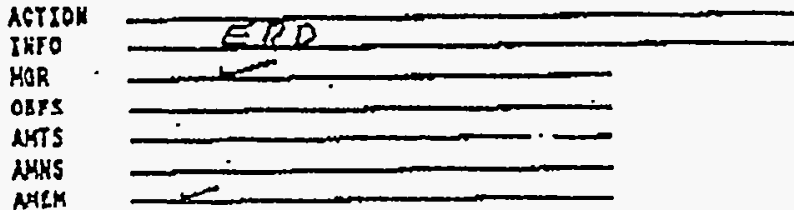


Appendix E

Pond Cleanup Verification Analytical Results

\begin{tabular}{|c|c|c|c|c|c|c|c|c|c|c|c|c|c|c|c|c|}
\hline IT Corp ID\# & RU-VSS-01 & & RU-VSS-01-1 & & RU-VSS-01-2 & & RU-VSS-02 & & RU-VSS-02-1 & & RU-VSS-03 & & RU-VSS-03-1 & & RU-VSS-04 & \\
\hline Date Collected & $9 / 7 / 95$ & & $9 / 9 / 95$ & & $10 / 13 / 95$ & & $9 / 7 / 95$ & & $9 / 9 / 95$ & & $8 / 31 / 95$ & & $9 / 9 / 95$ & & $8 / 31 / 95$ & \\
\hline Sample Location & Pond Floor & & Pond Floor & & Pond Floor & & Pond Floor & & Pond Floor & & Pond Floor & & Pond Floor & & Pond Floor & \\
\hline & Conc. & $\mathbf{Q}$ & Conc. & a & Conc. & $\mathbf{Q}$ & Conc. & $\mathbf{Q}$ & Conc. & $\mathbf{Q}$ & Conc. & $Q$ & Conc. & $\mathbf{Q}$ & Conc. & Q \\
\hline TPH: & $\mathrm{mg} / \mathrm{kg}$ & & $\mathrm{mg} / \mathrm{kg}$ & & $\mathrm{mg} / \mathrm{kg}$ & & $\mathrm{mg} / \mathrm{kg}$ & & $\mathrm{mg} / \mathrm{kg}$ & $\therefore$ & $\mathrm{mg} / \mathrm{kg}$ & & $\mathrm{mg} / \mathrm{kg}$ & $\because$ & $\mathrm{mg} / \mathrm{kg}$. & \\
\hline Nonspecilic & na & & 1,021 & $\mathrm{~J}$ & na & & na & & 700 & $\mathrm{~J}$ & na. & & 70 & $\mathrm{~J}$ & na & \\
\hline Diesel & 1.600 & & na & & 22 & & 1.700 & & na & & na & & na & & na & \\
\hline Waste Oil & na & & na & & na & & na & & na... & & na. & & na & & na & \\
\hline METALS:(TCLP) & $\therefore \mathrm{mg} / \mathrm{L}$ & & $m g / L$ & & mg/L & & $\mathrm{mg} / \mathrm{L}$ & & $\mathrm{mg} / \mathrm{L}$ & & $\mathrm{mg} / \mathrm{L}$. & & $m g / L$ & & $\mathrm{mg} / \mathrm{L}$ & \\
\hline Silver & na & & na & & na & & na & & na & & -na & & na & & na & \\
\hline Arsenic & na & & na & & na & & na & & na & & na & & na & & na & \\
\hline Barium & na & & na & & na & & na & & na & & na & & na. & & na & \\
\hline Cadmium & na & $\cdot$ & na & & na & & na & & na & & na & & na & & na & \\
\hline Chromium & na & & na & & na & & na & & na & & na & & na & & na & \\
\hline Lead & na & & na & & na & & na & & na & & na & & na & & na & \\
\hline Selenium & na & & na & & na & & na & & na & & na & & na & & na & \\
\hline Mercury & na & & na & & na & & na & & na & & na & & na & & na & \\
\hline ORGANICS:(TCLP) $\because \cdots$ & mig/L & $\because$ & $\therefore \mathrm{mg} \dot{\mathrm{g}} \mathrm{L} \ldots$ & $\because$ & $\because \quad$ mg̈几 & & mg/lin & & mgllasin & : & 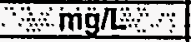 & 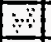 & ing/llon & $\therefore$ & ing $/ L$ & $\because$ \\
\hline Chloromethane & 50 & $\mathrm{U}$ & na & & na & & 50 & $\mathrm{U}$ & na & & 50 & U & na & & 50 & $\mathrm{U}$ \\
\hline Vinyl Chloride & 10 & $\mathrm{U}$ & na & & na & & 10 & $\mathrm{U}$ & na & & 10 & $\mathrm{U}$ & na & & 10 & $\bar{U}$ \\
\hline Bromomethane & 50 & $\mathrm{U}$ & na & & na & & 50 & $\mathbf{U}$ & na & & 50 & U & na & & 50 & $\mathbf{U}$ \\
\hline Chloroethane & 50 & $\mathrm{U}$ & na & & na & & 50 & $\mathbf{U}$ & na & & 50 & U & na & & 50 & $\mathbf{U}$ \\
\hline Acrolein & 120 & $\mathrm{U}$ & na & & na & & 120 & $\mathbf{U}$ & na & & 120 & U & na & & 120 & $U$ \\
\hline Acrylonitrile. & 120 & $\mathrm{U}$ & na: & & na & & 120 & $\mathbf{U}$ & na & & 120 & $\mathrm{U}$ & na & & 120 & $\mathrm{U}$ \\
\hline Methylene Chloride & 50 & $\mathbf{U}$ & na & & na & & 50 & $\mathrm{U}$ & na & & 50 & $\mathrm{U}$ & na & & 50 & U \\
\hline 1,1-Dichloroethene & 25 & $\mathrm{U}$ & na & & na & & 25 & $\mathrm{U}$ & na & & 25 & $U$ & na & & 25 & $\bar{U}$ \\
\hline trans-1.2-Dichloroethene & 25 & U & na & & na & & 25 & $\mathbf{U}$ & na & & 25 & $\underline{U}$ & na & & 25 & $U$ \\
\hline 1,1-Dichloroethane & 25 & U & na & & na & & 25 & $\mathrm{U}$ & na & & 25 & $\underline{U}$ & na & & 25 & $\bar{U}$ \\
\hline Chloroform & 5 & $\mathrm{~J}$ & na & & na & & 10 & $J$ & na & & 10 & $\mathrm{~J}$ & na & & 10 & $J$ \\
\hline 1,2-Dichloroethane & 25 & $\mathrm{U}$ & na & & na & & 25 & $\mathrm{U}$ & na & & 25 & U & na & & $\cdot 25$ & $\mathbf{U}$ \\
\hline 1,1,1-Trichloroethane & 25 & $\bar{U}$ & na & & na & & 25 & $\mathrm{U}$ & na & & 25 & U & na & & 25 & $\mathbf{U}$ \\
\hline Carbon Tetrachloride & 25 & U & na & & na & & 25 & $\mathrm{U}$ & na & & 25. & U & na & & 25 & $\mathbf{U}$ \\
\hline Trichloroethene & 25 & $\mathrm{U}$ & na & & na & & 25 & $\mathrm{U}$ & na & & 25 & U & na & & 25 & $\mathbf{U}$ \\
\hline 1,2-Dichloropropane & 25 & $\underline{U}$ & na. & & na & & 25 & $\mathrm{U}$ & na & & 25 & $\mathbf{U}$ & na & & 25 & $\bar{U}$ \\
\hline Benzene & 5 & $\mathbf{U}$ & nia & & 25 & $\underline{U}$ & 5 & $\mathrm{U}$ & na & & 5 & U & na & & 5 & $\bar{U}$ \\
\hline 2-Chloroethylvinyl ether & 50 & $\mathrm{U}$ & na & & na & & 50 & $\mathrm{U}$ & na & & 50 & $\underline{U}$ & na & & 50 & $U$ \\
\hline Bromodlchloromethane & 25 & $\mathrm{U}$ & na & & na & & 25 & $\mathrm{U}$ & na & & 25 & $\mathrm{U}$ & na & & 25 & $\mathbf{U}$ \\
\hline trans-1,3-Dichloropropene & 25 & $\mathrm{U}$ & na & & na & & 25 & $\mathbf{U}$ & na & & 25 & U & na & & 25 & 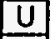 \\
\hline cis-1,3-Dichloropropene & 25 & $\mathrm{U}$ & na & & na & & 25 & $\bar{U}$ & na & & 25 & U & na & & 25 & $U$ \\
\hline 1,1,2-Trichloroethane & 25 & $\mathrm{U}$ & na & & na & & 25 & $\mathrm{U}$ & na & & 25 & $\mathrm{U}$ & na & & 25 & $U$ \\
\hline Chlorodibromomethane & 25 & $\mathrm{U}$ & na & & na & & 25 & U & na & & 25 & $\mathrm{U}$ & na & & 25 & $U$ \\
\hline Toluene & 25 & $\mathrm{U}$ & na & & na & & 25 & $\mathrm{U}$ & na & & 25 & $\mathrm{U}$ & na & & 25 & $U$ \\
\hline Tetrachloroethene & 25 & $\underline{U}$ & na & & na & & 25 & U & na & & 25 & U & na & & 25 & $U$ \\
\hline Chlorobenzene & 25 & $U$ & na & & na & & 25 & U & na & & 25 & U & na & & 25 & 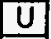 \\
\hline Ethylbenzene & 25 & $\mathrm{U}$ & na & & na & & 25 & $\mathrm{U}$ & na & & 25 & $\mathbf{U}$ & na & & 25 & $U$ \\
\hline Total Xylene & 25 & U & na & & na & & 25 & $\mathrm{U}$ & $\mathrm{na}$ & & 25 & $\bar{U}$ & na & & 25 & $\mathrm{U}$ \\
\hline Bromoform & 25 & $\mathrm{U}$ & na & & na & & 25 & $\underline{U}$ & na & & 25 & U & na & & 25 & $U$ \\
\hline 1,1,2,2-Tetrachloroethane & 25 & U & na & & na & & 25 & U & na & & 25 & U & na & & 25 & U \\
\hline
\end{tabular}


Appendix $E$

Pond Cleanup Verification Analytical Results

\begin{tabular}{|c|c|c|c|c|c|c|c|c|c|c|c|c|c|c|c|c|}
\hline IT Corp ID\# & RU-VSS-04-1 & & RU-VSS-04-2 & & RU-VSS-05 & & RU-VSS-05-1 & & RU-VSS-05-2 & & RU-VSS-06 & & RU-VSS-06-1 & & RU-VSS-07-1 & \\
\hline Date Collected & $9 / 9 / 95$ & & $10 / 13 / 95$ & & $8 / 31 / 95$ & & $9 / 9 / 95$ & & $10 / 13 / 95$ & & $8 / 31 / 95$ & & $9 / 9 / 95$ & & $9 / 9 / 95$ & \\
\hline Sample Location & Pond Floor & & Pond Floor & & Pond Floor & & Pond Floor & & Pond Floor & & Pond Floor & & Pond Floor & & Pond Floor & \\
\hline & Conc. & $\mathbf{Q}$ & Conc. & Q & Conc. & $\mathbf{Q}$ & Conc. & $\mathbf{Q}$ & Conc. & Q & Conc. & $\mathbf{Q}$ & Conc. & Q & Conc. & $\mathbf{Q}$ \\
\hline TPH: $\because \cdots$ & img/kg & & $\mathrm{mg} / \mathrm{kg}$ & & $\mathrm{mg} / \mathrm{kg}$ & & $\mathrm{mg} / \mathrm{kg}$ & $\div:$ & $\mathrm{mg} / \mathrm{kg}$ & 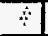 & $\mathrm{mg} / \mathrm{kg}$ & $\because$ & $\dot{\mathrm{mg}} / \mathrm{kg}$ & 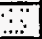 & $\mathrm{mg} / \mathrm{kg}$ & $\because$ \\
\hline Nonspecific & 685 & $\mathrm{~J}$ & na & & na & & 590 & $\mathrm{~J}$ & na & & na & & 138 & $\mathrm{~J}$ & 310 & $\mathrm{~J}$ \\
\hline Dlesel & na & & 160 & & na & & na & & 33 & & na & & na & & $\mathrm{na}$ & \\
\hline Waste Oil & na & & na & & na. & & na & & na & & na . & & na & & na & \\
\hline METALS:(TCLP) & $\ldots m g / L=$ & 3 & $\mathrm{mg} / \mathrm{h}$ & نسن & $\mathrm{mg} / \mathrm{L}$ & & $\therefore \mathrm{mg} / \mathrm{L}: \mathrm{m}$ & $\dot{3}$ & $\therefore \mathrm{mg} / \mathrm{L}-3$ & 2 & mg/L & $\because$. & mg/L & $\because$ & $\mathbf{m g} / \mathbf{L}:$ & $\therefore$ \\
\hline Silver & na & & na & & na & & 0.0044 & $\mathrm{U}$ & 0.50 & UJ & na & & na & & na & \\
\hline Arsenic '. & na & & na & & na & & 0.127 & $\mathrm{U}$ & 0.50 & $\mathrm{U}$ & na & & na & & na & \\
\hline Barium & na & & na & & na & & 1.92 & $B$ & 10.0 & $\mathrm{U}$ & na & & na & & na & \\
\hline Cadmium & na & & na & & na & & 0.0022 & $\mathrm{U}$ & 0.10 & U & na & & na & & na & \\
\hline Chromium & na & & na & & na & & 0.0033 & U & 0.10 & U & na & & na & & na & \\
\hline Lead & na & & na & & na & & 0.0422 & $\mathrm{U}$ & 0.50 & U & na & & na & & na & \\
\hline Selenium & na & & na & & na & & 0.147 & $\mathrm{U}$ & 0.10 & $\mathrm{U}$ & na & & na & & na & \\
\hline Mercury & na & & nia & & na & & 0.0 & $\mathrm{U}$ & 0.02 & $\mathrm{U}$ & na & & na & & na & \\
\hline ORGANICS: (TCLP) & 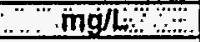 & 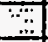 & :....mgll:": : & $\because$ & :mig/t: & $\because$ & $\therefore \mathrm{mg} / \mathrm{ln}$ & 要 & $\because \operatorname{mg} / l_{0}$ & : & mg $/ \mathrm{a}$ & * & ing ill & 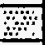 & mg/lis: & \\
\hline Chloromethane & na & & na & & 50 & U & na & & na & & 50 & $\mathrm{U}$ & na & & 50 & $\bar{U}$ \\
\hline Vinyl Chloride & na & & na & & 10 & $\mathrm{U}$ & na & & na & & 10 & $\mathrm{U}$ & na & & 10 & $\bar{U}$ \\
\hline Bromomethane & na & & na & & 50 & $\mathrm{U}$ & na & & na & & 50 & $\mathbf{U}$ & na & & 50 & $\bar{U}$ \\
\hline Chloroethane & na & & na & & 50 & $\bar{U}$ & na & & na & & 50 & $\mathrm{U}$ & na & & 50 & $\bar{U}$ \\
\hline Acrolein & na & & na & & 120 & $U$ & na & & na & & 120 & $\mathrm{U}$ & na & & 120 & $\mathrm{U}$ \\
\hline Acrylonitrile & na & & na & & 120 & $\mathrm{U}$ & na & & na & & 120 & $\mathrm{U}$ & na & & 120 & $\bar{U}$ \\
\hline Methylene Chloride & na & & na & & 50 & $\mathrm{U}$ & na & & na & & 50 & $\mathrm{U}$ & na & & 50 & U \\
\hline 1,1-Dichloroelhene & na & & na & & 25 & U & na & & na & & 25 & $\mathbf{U}$ & na & & 25 & $\bar{U}$ \\
\hline trans-1,2-Dichloroethene & na & & na & & 25 & $\mathrm{U}$ & na & & na & & 25 & $\mathrm{U}$ & na & & 25 & $\mathrm{U}$ \\
\hline 1,1-Dichloroethane & na & & na & & 25 & $\mathrm{U}$ & na & & na & & 25 & $\mathrm{U}$ & na & & 25 & $\bar{U}$ \\
\hline Chloroform & na & & na & & 25 & $\mathrm{U}$ & na & & na & & 10 & $\mathrm{~J}$ & na & & 15 & $\mathrm{~J}$ \\
\hline 1,2-Dichloroelhane & na & & na & & 25 & $\mathrm{U}$ & na & & na & & 25 & $\mathrm{U}$ & na & & 25 & $\bar{U}$ \\
\hline 1,1,1-Trichloroethane & na & & na & & 25 & $\bar{U}$ & na & & na & & 25 & $\mathrm{U}$ & na & & 25 & $\bar{U}$ \\
\hline Carbon Tetrachloride & na & & na & & 25 & $\mathrm{U}$ & na & & na & & 25 & U & na & & 25 & $\bar{U}$ \\
\hline Trichloroethene & na & & na & & 25 & $\mathrm{U}$ & na & & na & & 25 & $\bar{U}$ & na & & 25 & $\bar{U}$ \\
\hline 1,2-Dichloropropane & na & & na & & 25 & $\mathrm{U}$ & na & & na & & 25 & $\bar{U}$ & na & & 25 & $\bar{U}$ \\
\hline Benzene & na & & 25 & U. & 5 & $\mathrm{U}$ & na & & 25 & $\mathrm{U}$ & 5 & U & na & & 5 & $\mathrm{U}$ \\
\hline 2-Chloroelhylvinyl elher & na & & na & & 50 & $\mathrm{U}$ & na & & na & & .50 & $\bar{U}$ & na & & 50 & $\bar{U}$ \\
\hline Bromodichloromethane . & na & & na & & 25 & $\mathrm{U}$ & na & & na & & 25 & $\bar{U}$ & $n a \ldots$ & & 25 & U \\
\hline trans-1,3-Dichloropropene & na & & na & & 25 & $\mathrm{U}$ & na & & na & & 25 & $\mathbf{U}$ & na & & 25 & $\mathrm{U}$ \\
\hline cis-1,3-Dichloropropene & na & & na & & 25 & $\mathrm{U}$ & na & & ńa & & 25 & $\mathbf{U}$ & na & & 25 & U \\
\hline 1,1,2-Trichloroethane & na & & na & & 25 & $\mathrm{U}$ & na & & na & & 25 & $\mathbf{U}$ & $n a$ & & 25 & $\bar{U}$ \\
\hline Chlorodibromomethane & na & & na & & 25 & $\mathrm{U}$ & na & & na & & 25 & $\mathbf{U}$ & na & & 25 & $\bar{U}$ \\
\hline Toluene & na & & na & & 25 & $\mathrm{U}$ & na & & na & & 25 & $\mathrm{U}$ & na & & 25 & $\bar{U}$ \\
\hline Tetrachloroethene & na & & na & & 25 & $\mathrm{U}$ & na & & na & & 25 & $\mathbf{U}$ & na & & 25 & $\bar{U}$ \\
\hline Chlorobenzene & na & & na & & 25 & $\mathrm{U}$ & na & & na & & 25 & $\mathbf{U}$ & na & & 25 & $\bar{U}$ \\
\hline Elhylbenzene & na & & na & & 25 & $\mathbf{U}$ & na & & $\overline{\text { na }}$ & & 25 & $\bar{U}$ & na & & 25 & $\bar{U}$ \\
\hline Total Xylene & na & & na & & 25 & $\bar{U}$ & na & & na & & 25 & $\mathbf{U}$ & na & & 25 & $\bar{U}$ \\
\hline Bromoform & na & & na & & 25 & $\bar{U}$ & na & & na & & 25 & $\mathrm{U}$ & na & & .25 & U \\
\hline $1,1,2,2$-Tetrachloroethan $\theta$ & na & & na & & 25 & $U$ & na & & na & & 25 & u & na & & 25 & $\bar{U}$ \\
\hline
\end{tabular}


Appendix E

Pond Cleanup Verification Analytical Results

\begin{tabular}{|c|c|c|c|c|c|c|c|c|c|c|c|c|c|c|c|c|}
\hline IT Corp ID\# & RU-VSS-08 & & RU-VSS-08-1 & & RU-VSS-09 & & RU-VSS.09.1 & & RU-VSS-10-1 & & RU-VSS-11-1 & & RU-VSS-12 & & RU-VSS-13 & \\
\hline Date Collected & $9 / 7 / 95$ & & $9 / 9 / 95$ & & $9 / 7 / 95$ & & $9 / 9 / 95$ & & $9 / 9 / 95$ & & $9 / 9 / 95$ & & $10 / 13 / 95$ & & $10 / 14 / 95$ & \\
\hline Sample Location & Pond Floor & & Pond Floor & & Pond Floor & & Pond Floor & & Pond Floor & & Pond Floor & & Pond Floor & & Pond Floor & \\
\hline & Conc. & Q & Conc. & $\mathbf{Q}$ & Conc. & $\mathbf{Q}$ & Conc. & Q & \begin{tabular}{|c|} 
Conc. \\
\end{tabular} & $\mathbf{Q}$ & Conc. & $Q$ & Conc. & $\mathbf{Q}$ & Conc. & $Q$ \\
\hline TPHA & $m g / \mathrm{kg}_{. . .}$ & 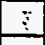 & $\mathrm{mg} / \mathrm{kg}$ & & $\mathrm{mg} / \mathrm{kg}$ & & ing/kg & $\therefore$ & $\therefore \mathrm{mg} / \mathrm{kg}$ & & $\mathrm{mg} / \mathrm{kg}$ & $\cdots$ & $\mathrm{mg} / \mathrm{kg}: \because$ & $\because$ & $\because \mathrm{mg} / \mathrm{kg}: \because$ & $\because$ \\
\hline Nonspecific & na & & 10 & UJ & na & & na & & 176. & $J$ & 177 & $\mathrm{~J}$ & na & & na & \\
\hline Diesel & 260 & & na & & 49 & & na & & na & & na & & 320 & & $2, \overline{600}$ & D \\
\hline Waste Oil & $\ldots$ na & & $\ldots$ na & & -na- & & na & & na & $\cdots$ & $-n a$ & - & $\cdots$ na & & \begin{tabular}{|r|}
-25 \\
\end{tabular} & $\bar{U}$ \\
\hline METALS:(TCLP) & $\mathrm{mgh}$ & & $m g / L$ & تـت & $\cdots \mathrm{mg} / \mathrm{L}:$ & & "mg/L" & $\therefore$ & $\mathrm{mg} / \mathrm{L}$ & $\because=$ & $m g / L$ & 3 & mg/L: & $\because:$ & $\because \mathrm{mg} / \mathrm{L}$ & \\
\hline Silver & 0.0044 & $\mathrm{U}$ & na & & na & & na & & na & & na & & na & & $-n a$ & \\
\hline Arsenic & 0.127 & $\mathrm{U}$ & na & & na & & na & & na & & na & & na & & na & \\
\hline Barium & 1.37 & & na & & na & & na & & na & & na & & na & & na & \\
\hline Cadmium & 0.0133 & & na & & na & & na & & na & & na & & na & & na & \\
\hline Chromium & 0.0033 & $\mathrm{U}$ & na & & na & & na & & na & & na & & na & & na & \\
\hline Lead & 0.0422 & $\mathrm{U}$ & na & & na & & na & & na & & na & & na & & na & \\
\hline Selenium & 0.147 & $\mathbf{U}$ & na & & na & & na & & na & & na & & na & & na & \\
\hline Mercury. & 0.002 & $\mathrm{U}$ & na & & na. & & na & & na & & \begin{tabular}{|l} 
na \\
\end{tabular} & & na &. & na & \\
\hline ORGANICS: (TCLP) & $\therefore \mathrm{mg} / \mathrm{h}$. & & img/h & $\ddot{*}$ & $\mathrm{mg} / \mathrm{m}$. & & $\mathrm{mg} / \mathrm{L}:$ & $\therefore$ & mgill: & $\because$ & Amgla & $\because$ & mgra: & 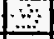 & mg/h & \\
\hline Chloromelhane & 50 & $\mathrm{U}$ & na. & & 50 & $\mathrm{U}$ & na & & 50 & U & 50 & $\mathrm{U}$ & na & & na & \\
\hline Vinyl Chloride & 10 & U & na & & 10 & $\mathrm{U}$ & na & & 10 & $U$ & 10 & $\mathrm{U}$ & na & & na & \\
\hline Bromomethane & 50 & U & na & & 50 & $\mathrm{U}$ & na & & 50 & $\mathrm{U}$ & 50 & $\mathrm{U}$ & na & & na & \\
\hline Chloroethane & 50 & $\mathrm{U}$ & na & & 50 & $\mathrm{U}$ & na & & 50 & $\mathrm{U}$ & 50 & $\mathbf{U}$ & na & & - na & \\
\hline Acrolein & 120 & U & na & & 120 & U & na & & 120 & $\mathrm{U}$ & 120 & $\mathbf{U}$ & na & & $\cdots n a$ & \\
\hline Acrylonitrile & 120 & $\mathrm{U}$ & na & & 120 & $\mathrm{U}$ & na & & 120 & $U$ & 120 & $\mathbf{U}$ & na & & $\cdots$ na & \\
\hline Methylene Chloride & 50 & $\mathrm{U}$ & na & & 50 & $\mathrm{U}$ & na & & 50 & $\mathrm{U}$ & 50 & $\mathbf{U}$ & na & & $\cdots$ na & \\
\hline 1,1-Dichloroethene & 25 & $\mathrm{U}$ & na & & 25 & $\mathrm{U}$ & na & & 25 & $\mathrm{U}$ & 25 & $\mathbf{U}$ & na & & - na & \\
\hline trans-1,2-Dichloroethene & 25 & $\mathrm{U}$ & na & & 25 & $\mathrm{U}$ & na & & 25 & U & 25 & $\underline{U}$ & na & & $\cdots$ na & \\
\hline 1,1-Dichloroethane & 25 & U & na & & 25 & $U$ & na & & $25 \cdot$ & U & 25 & U & na & & - na & \\
\hline Chloroform : & 10 & $J$ & na & & 25 & U & na & & 15 & $\mathrm{~J}$ & 15 & $\mathrm{~J}$ & na & & - na & \\
\hline 1,2-Dichloroethane & $25^{\circ}$ & $\mathrm{U}$ & na & & 25 & $\mathrm{U}$ & na & & 25 & U & 25 & $\mathrm{U}$ & na & & na & \\
\hline 1,1,1-Trichloroelhane & 25 & $\mathrm{U}$ & na & $\dot{-}$ & 25 & $\underline{U}$ & na & & 25 & $\mathrm{U}$ & 25 & $\mathbf{U}$ & na & & na & \\
\hline Carbon Tetrachloride & .25 & $\mathrm{U}$ & na & & 25 & U & na & & 25 & $\bar{U}$ & 25 & $U$ & na & & - na & \\
\hline Trichloroethene & 25 & U & na & & 25 & $U$ & na & & 25 & $\mathrm{U}$ & 25 & $\mathrm{U}$ & na & & - na & \\
\hline 1,2-Dichloropropane & 25 & $\mathrm{U}$ & na & & 25 & $\mathrm{U}$ & na & & 25 & $\mathrm{U}$ & 25 & $\mathrm{U}$ & na & & $\cdots$ na & \\
\hline Benzene & 5 & $U$ & na & & 5 & $\mathrm{U}$ & na & & 5 & $\mathrm{U}$ & 5 & $\mathrm{U}$ & 25 & $\mathrm{U}$ & $=10$ & U \\
\hline 2-Chloroethylvinyl ether & 50 & $\mathrm{U}$ & na & & 50 & $\mathrm{U}$ & na & & 50 & $U$ & 50 & $\mathrm{U}$ & na & & na & \\
\hline Bromodichloromethane & 25 & $\mathrm{U}$ & na & & 25 & $\mathrm{U}$ & na & & 25 & $\mathrm{U}$ & 25 & $\mathrm{U}$ & na & & na & \\
\hline trans-1,3-Dichloropropene & 25 & $\mathrm{U}$ & na & & 25 & U & na & & 25 & $\mathrm{U}$ & 25 & $U$ & na & & ina & \\
\hline cis-1,3-Dichloropropene & 25 & U & na & & 25 & $\mathrm{U}$ & na & & $25^{\prime}$ & U & 25 & $\mathrm{U}$ & na & & na & \\
\hline 1,1,2-Trichloroethane & 25 & $U$ & na & & 25 & U & na & & 25 & $\mathrm{U}$ & 25 & U & na & & na & \\
\hline Chlorodibromomethane. & 25 & $\mathrm{U}$ & na & & 25 & $\mathrm{U}$ & na & & 25 & $\mathrm{U}$ & 25 & $\mathrm{U}$ & na & & $\approx$ na & \\
\hline Toluene & 25 & $\mathrm{U}$ & na & & 25 & $\mathrm{U}$ & na & & 25 & $\bar{U}$ & 25 & $\mathrm{U}$ & na & & $\cdots$ na & \\
\hline Tetrachloroethene & 25 & $\mathrm{U}$ & na & & 25 & $\mathbf{U}$ & na. & & 25 & $\mathrm{U}$ & 25 & $\bar{U}$ & na & & na & \\
\hline Chlorobenzene & 25. & $\mathrm{U}$ & na & & 25 & $\mathrm{U}$ & na & & 25 & $\mathrm{U}$ & 25 & $\mathrm{U}$ & na & & na & \\
\hline Ethylbenzene & 25 & U & na & & 25 & $\mathrm{U}$ & na & & 25 & U & 25 & $\mathrm{U}$ & na & & $=$ na & \\
\hline Tolal Xylene & 25. & $\mathrm{U}$ & na & & 25 & $\mathrm{U}$ & na & & 25 & $\mathrm{U}$ & 25 & $\mathrm{U}$ & na & & na & \\
\hline Bromoform & 25 & U & na & & 25 & $\mathrm{U}$ & na & & 25 & $\mathrm{U}$ & 25 & $\mathrm{U}$ & na & & na & \\
\hline 1,1,2,2-Tetrachloroethane & 25 & $\mathrm{U}$ & na & & 25 & $\mathrm{U}$ & na & & 25 & $U$ & 25 & $\mathrm{U}$ & na & & na & \\
\hline
\end{tabular}


Appendix E

Pond Cleanup Verification Analytical Results

\begin{tabular}{|c|c|c|c|c|c|c|c|c|c|c|c|c|c|c|c|c|}
\hline IT Corp IDA & RU-VSS-13-1 & & RU-VSS-14 & & RU-VSS-15 & & RU-VSS-16 & & RU-VSS-17 & & RU-VSS-18 & & RU-VSS-19 & & RU-VSS-19-1 & \\
\hline Date Collected & $10 / 19 / 95$ & & $10 / 13 / 95$ & & $10 / 13 / 95$ & & $10 / 12 / 95$ & & $10 / 12 / 95$ & & $10 / 12 / 95$ & & $10 / 12 / 95$ & & $10 / 18 / 95$ & \\
\hline Sample Location & Pond Floor & & Pond Floor & & Pond Floor & & Pond Floor & & Pond Floor & & Pond Floor & & Pond Floor & & Pond Floor & \\
\hline & Conc. & Q & Conc. & Q & Conc. & a & Conc. & a & Conc. & Q & Conc. & Q & Conc. & Q & Conc. & Q \\
\hline TPH: ... & $\mathrm{mg} / \mathrm{kg}$ & & $\mathrm{mg} / \mathrm{kg}$ & & $\mathrm{mg} / \mathrm{kg}$ & & $\mathrm{mg} / \mathrm{kg}$ & & $\mathrm{mg} / \mathrm{kg}$ & & $\mathrm{mg} / \mathrm{kg}$ & $\because$ & $\mathrm{mg} / \mathrm{kg}$. & $\therefore$ & $\therefore \mathrm{mg} / \mathrm{kg}$ & \\
\hline Nonspecific & na & & na & & na & & na & & na & & na & & na & & na & \\
\hline Diesel & 840 & & 7.1 & & 180 & & 25 & $\underline{U}$ & 210 & & 29 & & 16,000 & & 370 & \\
\hline Waste Oil & na & & $\mathrm{na}$ & & na & & 25 & U & 25 & $\mathrm{U}$ & na & & na & & na & \\
\hline METALS: (TCLP). & $\mathrm{mg} / \mathrm{L}$ & & $\mathrm{mg} / \mathrm{L}$. & & $\mathrm{mg} / \mathrm{L}$ & & $\mathrm{mg} / \mathrm{L}$. & $\therefore$ & $\mathrm{mg} / \mathrm{L}$ & & $\mathrm{mg} / \mathrm{L}$ & 3 & mig/L: & $\therefore$ & $\cdots \mathrm{mg} / \mathrm{L}$ & \\
\hline Silver & na & & na & & 0.50 & UJ & na & & na & & na & & na & & na & \\
\hline Arsenic & na & & na & & 0.50 & $\mathrm{U}$ & na & & na & & na & & na & & na & \\
\hline Barium & na & & na & & 10.0 & U & na & & na & & na & & na & & na & \\
\hline Cadmium & na & & na & & 0.10 & $\mathrm{U}$ & na & & na & & na & & na & & na & \\
\hline Chromium & na & & na & & 0.10 & $U$ & na & & na & & na & & na & & na & \\
\hline Lead & na & & na & & 0.50 & $U$ & na & & na & & na & & na & & na & \\
\hline Selenium & na & & na & & 0.10 & $\mathrm{U}$ & na & & na & & na & & na & & na & \\
\hline Mercury & na & & na & & 0.02 & U & na & & na & & na & & na & & na & \\
\hline ORGANICS:(TCLP) & $m g / L$ & & mg/l & $\therefore$ & $\underline{m g} / \mathbf{L} \ldots$ & $\because$ & $\therefore \mathrm{mg} / \mathrm{L}: \cdots$ & $\because$ & $m g / L: \cdots$ & $\therefore$ & mgll: & $\because$ & $\cdots, \quad$ mg $/ L \therefore$ & $\because$ & $\therefore \mathrm{mg} / \mathrm{L}:$ & \\
\hline Chloromelhane & na & & na & & na & & na & & na & & na & & na & & na & \\
\hline Vinyl Chloride & na & & na & & na & & na & & na & & na & & na & & na & \\
\hline Bromomethane & na & & na & & na & & na & & na & & na & & na & & na & \\
\hline Chloroethane & na & & na & & na & & na & & na & & na & & na & & na & \\
\hline Acrolein & na & & na & & na & 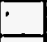 & na & & na & & na & & na & & na & \\
\hline Acrylonitrile & na. & & na & & na & & na & & na- & & na & & na & & na & \\
\hline Methylene Chloride & na & & na & & na & & na & & na & & na & & na & & na & \\
\hline 1,1-Dichloroelhene & na & & na & & na & & na & & na & & na & & na & & na & \\
\hline Irans-1,2-Dichloroethene & na & & na & & na & & na & & na. & & na & & na & & na & \\
\hline 1,1-Dichloroethane & na & & na & & na & & na & & na & & na & & na & & na & \\
\hline Chloroform & na & & na & & na & & na & & na & & na & & na & & na & \\
\hline 1,2-Dichloroethane & na & & na & & na & & na & & na & & na & & na & & na & \\
\hline 1,1,1-Trichloroethane & na & & na & & na & & na & & na & & na & & na & & na & \\
\hline Carbon Tetrachloride & na & & na & & na & & na & & na & & na & & na & & na & \\
\hline Trichloroethene & na. & & na & & na & & na & & na & & na & & na & & na & \\
\hline 1,2-Dichloropropane & na & & na & & na & & na & & na & & na & & na & & na & \\
\hline Benzene & 25 & $\mathbf{U}$ & 25 & $\underline{U}$ & 25 & U & 10 & $\mathrm{U}$ & 10 & $\mathbf{U}$ & 25 & $\mathrm{U}$ & 25 & U & na & \\
\hline 2-Chloroethylvinyl elher & na & & na & & na & & na & & na & & na & & na & & na & \\
\hline Bromodichloromethane & na & & na & & na & & na & & na & & na & & na & & na & \\
\hline trans-1,3-Dichloropropene & na. & & -na & & na & & na & & na & & na & & na & & na & \\
\hline cis-1,3-Dichloropropene & na & & na & & na & & na & & na & & na & & na & & na & \\
\hline 1,1,2-Trichloroethane & na & & na & & na & & na & & na & & na & & na & & na & \\
\hline Chlorodibromomethane & na & & na & & na & & na & & na & & na & & na & & na & \\
\hline Toluene & na & & na & & na & & na & & na & & na & & na & & na & \\
\hline Tetrachloroethene & na & & na & & na & & na & & na & & na & & na & & na & \\
\hline Chlorobenzene & na & & na & & na & & na & & na & & na & & na & & na & \\
\hline Elhylbenzene & na & & na & & na & & na & & na & & na & & na & & na & \\
\hline Total Xylene & na & & na & & na & & na & & na & & na & & na & & na & \\
\hline Bromoform & na & & na & & na & & na & & na & & na & & na & & na & \\
\hline 1,1,2,2-Tetrachloroethane & na & & na & & na & & na & & na & & na & & na & & na & \\
\hline
\end{tabular}


Appendix $E$

Pond Cleanup Verification Analytical Results

\begin{tabular}{|c|c|c|c|c|c|c|c|c|c|c|c|c|c|c|c|c|}
\hline IT Corp IDH & RU-VSS-20 & & RU-VSS-20-1 & & RU-VSS-20-2 & & RU-VSS-120 & & RU-VSS-21 & & RU-VSS-22 & & RU-VSS-23 & & RU-VSS-24 & \\
\hline Date Collected & $10 / 12 / 95$ & & $10 / 18 / 95$ & & $10 / 21 / 95$ & & $10 / 12 / 95$ & & $10 / 12 / 95$ & & $10 / 12 / 95$ & & $10 / 12 / 95$ & & $10 / 12 / 95$ & \\
\hline Sample Locatlon & Pond Floor & & Pond Floor & & Pond Floor & & Pond Floor & & Pond Floor & & Pond Floor & & Pond Floor & & Pond Floor & \\
\hline & Conc. & $\mathbf{Q}$ & Conc. & $\mathbf{Q}$ & Conc. & 0 & Conc. & $\mathbf{Q}$ & Conc. & $\mathbf{Q}$ & Conc. - & Q & Conc. & a & Conc. & a \\
\hline TPH: & $\mathrm{mg} / \mathrm{kg}$ & & $\mathrm{mg} / \mathrm{kg}$ & & $\mathrm{mg} / \mathrm{kg}$ & & $\mathrm{mg} / \mathrm{kg}$ & & $\mathrm{mg} / \mathrm{kg}$ & & $\mathrm{mg} / \mathrm{kg}$ & & $\mathrm{mg} / \mathrm{kg}$ & & $\mathrm{mg} / \mathrm{kg}$ & \\
\hline Nonspecific & $\mathrm{na}$ & & na & & na & & na & & na & & na & & na. & & na & \\
\hline Diesel & 2,500 & & 1.500 & & 150 & & na & & 2.4 & $\mathrm{U}$ & 370 & & 25 & u & 170 & \\
\hline Waste Oil & na & & na & & na & & na & & na & & na & & 25 & $\mathrm{U}$ & 25 & $\mathrm{U}$ \\
\hline METALS: (TCLP) & $\mathrm{mg/L}$ & & $\mathrm{mg} / \mathrm{L}$ & & $\mathrm{mg} / \mathrm{l}$ & & $m g / L$ & & $\mathrm{mg} \Omega$ & & $\mathrm{mg} / \mathrm{L}$ & & $m g / L$ & 8 & $\mathrm{mg} / \mathrm{L}$ & \\
\hline Silver & 0.50 & $\mathrm{U}$ & na & & na & & na & & na & & na & & na & & na & \\
\hline Arsenic & 0.50 & $\mathrm{U}$ & $n a$ & & na & & na & & na & & na & & na & & na & \\
\hline Barium & 10.0 & U & na. & & na & & na & & na & & na & & na & & na & \\
\hline Cadmium & 0.10 & $\mathrm{u}$ & na & & na & & na & & na & & na & & na & & na & \\
\hline Chromium & 0.10 & $\mathrm{U}$ & na & & na & & na & & na & & na & & na & & $\mathrm{na}$ & \\
\hline Lead & 0.50 & $\mathrm{U}$ & na & & na & & na & & na & & na & & na & . & na & \\
\hline Selenium & 0.10 & $\mathrm{U}$ & na & & na & & na & & na & $\dot{ }$ & na & & na & - & na & \\
\hline Mercury & 0.020 & $\mathrm{U}$ & na & & na & & na & & na & & na & & na & & na & \\
\hline ORGANICS: (TCLP) $\because$ & mg/l. & & ingli: & & $\mathrm{mg} / \mathrm{L}:$ & $\therefore$ & ming $/ \mathrm{a}$ & 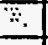 & migll :.: & $\because$ & mig/h & $\because:$ & $\therefore \mathrm{mg} / \mathrm{L}$ & 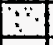 & $\therefore \mathrm{mg} / \mathrm{L}$ & $\because$ \\
\hline Chloromelhane & na & & na & & na & & . na & & na & & na & & na & . & na & \\
\hline Vinyl Chloride & na & & na & & na & & na & & na & & na & & na & & na & \\
\hline Bromomelhane & na & & na & & $\mathrm{na}$ & & na & & na & & na & & na & & na & \\
\hline Chloroethane & na & & na & & na & & na & & na & & na & & na & $\dot{\square}$ & na & \\
\hline Acrolein & na & & na & & na & & na & & na & & na & & na & . & na & \\
\hline Acrylonitrile & na & & na & & na & & na & & na & & na & & na & & na & \\
\hline Methylene Chloride & na & & na & & na & & na & & na & & na & & na & & na & \\
\hline 1,1-Dichloroethene & na & & na & & na & & na & & na & & na & & na & & na & \\
\hline trans-1,2-Dichloroethene & na & & na & & na & & na & & na & & na & & na & & na & \\
\hline 1,1-Dichloroethane & na & & na & & na & & na & & na & & na & & na & & na & \\
\hline Chlorolorm & na & & na & & na & & na & & na. & & na & & na & & na & \\
\hline 1,2-Dichloroethane & na & & na & & na & & na & & na & & na & & na & & na & \\
\hline 1,1,1-Trichloroethane & na & & na & & na & & na & & na & & na & & na & & na & \\
\hline Carbon Tetrachloride & na & & na & & na & & na & & na & & na & & na & & na & \\
\hline Trichloroethene & na & & na & & na & & na & & na & & na & & na & & na & \\
\hline 1,2-Dichloropropane & na & & na & & na & & na & & na & & na & & na & & na & \\
\hline Benzene & 25 & U & na & & na & & na & & 25 & $\mathrm{U}$ & 25 & $\mathrm{U}$ & 10 & $\mathrm{U}$ & 10 & U \\
\hline 2-Chloroolhyivinyl ether & na & & na & & na & & na & & na & & na & & na & & na & \\
\hline Bromodichloromethane & na & & na & & na & & na & & na & & na & i & na & & na & \\
\hline trans-1,3-Dichloropropene & na & & na & & na & & na & & na & & na & & na & & na & \\
\hline cis-1,3-Dichloropropene & na & & na & & na & & na & & na & & na & & na & & na & \\
\hline 1,1,2-Trichloroethane & na & & na & & na & & na & & na & & na & & na & & na & \\
\hline Chlorodibromomethane & na & & na. & & na & & na & & na & & na & & na & & na & \\
\hline Toluene & na & & na & & na & & na & & na & & na & & na & & na & \\
\hline Tetrachloroethene & na & & na & & na & & na & & na & & na & & na & & na & \\
\hline Chlorobenzene & na & & na & & na & & na & & na & & na & & na & & na & \\
\hline Ethylbenzene & na & & na & & na & & na & & na & & na' & & na & & na & \\
\hline Total Xylene & na & & na & & na & & na & & na & & na & & na & & na & \\
\hline Bromoform & na & & na & & na & & na & & na & & na & & na & & na & \\
\hline $1,1,2,2-$ Tetrachloroethane & na & & na & & na & & na & & na & & na & & na & & na & \\
\hline
\end{tabular}


Appendix $E$

Pond Cleanup Verification Analytical Results

\begin{tabular}{|c|c|c|c|c|c|c|c|c|c|c|c|c|c|c|c|c|}
\hline IT Corp ID\#| & RU-VSS-25 & $\cdot$ & RU-VSS-26 & & RU-VSS-26-1 & & RU-VSS-27 & & RU-VSS-27-12 & & RU-VSS-28 & & RU-VSS-29 & & RU-VSS-29-1 & \\
\hline Date Collected & $10 / 13 / 95$ & & $10 / 13 / 95$ & & $10 / 18 / 95$ & & $10 / 14 / 95$ & & $10 / 14 / 95$ & & $10 / 13 / 95$ & & $10 / 13 / 95$ & & $10 / 18 / 95$ & \\
\hline Sample Locatlon & Pond Floor & & Pond Floor & & Pond Floor & & Pond Floor & & Pond Floor & & Pond Floor & & Pond Floor & & Pond Floor & \\
\hline & Conc. & $\mathbf{Q}$ & Conc. & Q & Conc. & Q & Conc. & Q & Conc. & Q & Conc. & Q & Conc. & Q & Conc. & Q \\
\hline TPH: ...... & $\mathrm{mg} / \mathrm{kg}$ & & $\mathrm{mg} / \mathrm{kg}$ & & $\mathrm{mg} / \mathrm{kg}$ & & $\mathrm{mg} / \mathrm{kg}$ & $\because$ & $\mathrm{mg} / \mathrm{kg}$ & $\because$ & $\mathrm{mg} / \mathrm{kg}$ & $\pi$ & $\mathrm{mg} / \mathrm{kg}$ & & $\because \mathrm{mg} / \mathrm{kg}$ & \\
\hline Nonspecific & na & & na & & na & & na & & na & & na & & na & & na & \\
\hline Diesel & 680 & & 1,400 & & 31 & & 160 & & 740 & & 77 & & 2,000 & $\div$ & 77 & \\
\hline Waste Oil & na & & na & & na & & 25 & U & na & & na & & na & & $\mathrm{na}$ & \\
\hline METALS:(TCLP) & $\therefore \mathrm{mg} / \mathrm{L} ; \mathrm{a}$ & $\therefore$ & $m g / L$ & & $m g / L$ & & mg/L...... & $\dot{a}$ & mg/L:: & 3 & $\mathrm{mg} / \mathrm{L}$ & $\because$ & mg/L & $\because$ & $m g^{\prime} / L$ & $\therefore$ \\
\hline Silver & 0.50 & UJ & na & & na & & 0.006 & $\mathrm{U}$ & 0.50 & $\mathrm{U}$ & na & $\therefore$ & na & 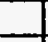 & na & \\
\hline Arsenic & 0.50 & $\mathbf{U}$ & na & & na & & 0.0377 & $\mathrm{U}$ & 0.50 & $\mathrm{U}$ & na & 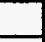 & na & & na & \\
\hline Barium & 10.0 & $\mathrm{U}$ & na & & na & & 2.42 & & 10.0 & U & na & 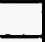 & na & & na & \\
\hline Cadmium & 0.10 & $\mathbf{U}$ & na & & na & & 0.0058 & & 0.10 & U & na & 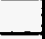 & na & & na & \\
\hline Chromium & 0.10 & $\mathbf{U}$ & na & & na & & 0.0037 & U & 0.10 & $\mathrm{U}$ & na & 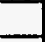 & na & & na & \\
\hline Lead & 0.50 & U & na & & na & & 0.0382 & U & 0.50 & U & na & . & na & & na & \\
\hline Selenium & 0.10 & $\mathbf{U}$ & na & & na & & 0.055 . & $B$ & 0.10 & U. & na & 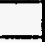 & na & & na & \\
\hline Mercury & 0.02 & $\mathbf{U}$ & na & & na & & 0.0001 & $\mathrm{U}$ & 0.020 & U & na & & na & & na & \\
\hline ORGANICS: (TCLP) & $\therefore \mathrm{mg} / \mathrm{h}$ & & $\mathrm{mg} / \mathrm{h}$ & & $\mathrm{mg} / \mathrm{L}$ & & migh & $\therefore$ & mgilli:............. & + & migll & 3 & : m $\ddot{g} / L$ & $\because$ & $\ddot{m} g / l:::=$ & $\therefore$ \\
\hline Chloromethane & na & & na. & & na & & na & & na & & na & & na & & na & \\
\hline Vinyl Chloride & na & & na & & na & & na & & na & & na & & na & & na & \\
\hline Bromomethane & na & & na & & na & & na & & na & & na & & na & & na & \\
\hline Chloroethane & na & & na & & na & & na & & na & & na & & na & & na & \\
\hline Acrolein & na & & na & & na & & na & & na & & na & & na & & na & \\
\hline Acrylonitrile & na & & na & & na & & na & & na & & na & & na. & & na & \\
\hline Methylene Chloride & na & & na & & na & & na & 1 & na & & na & & na & & na & \\
\hline 1,1-Dichloroelhene & na & & na & & na & & na & & na & & na & & na & & na & \\
\hline Irans-1,2-Dichloroethene & na & & na & & na & $\cdot$ & na & & na & & na & - & na & & na & \\
\hline 1.1-Dichloroelhane & na & & na & & na & & na & & na & & na & & na & & na & \\
\hline Chloroform & na & & na & & na & & na & & na & & na & & na & & na & \\
\hline 1,2-Dichloroethane & na & & na & & na & & na & & na & & na & & na & & na & \\
\hline 1,1,1-Trichloroethane & na & & na & & na & & na & & na & & na & & na & - & na & \\
\hline Carbon Tefrachloride & na & & na & & na & & na & & na & & na & & na & & na & \\
\hline Trichloroethene & na & & na & & na & & na & & na & & na & & na & & na & \\
\hline 1,2-Dichloropropane & na & & na & & na & & na & & na & & na & & na & & na & \\
\hline Benzene & 25 & U & 25 & U & na & & 10 & $\mathrm{U}$ & 25 & $U$ & 25 & $\underline{U}$ & 25 & $\mathbf{U}$ & na & \\
\hline 2-Chloroethylvinyl ether & na & & na & & na & & na & & na & & na & & na & & na & \\
\hline Bromodichloromethane & na & & na & & na & & na & & na & & na & & na & & na & \\
\hline trans-1,3-Dichloropropene & na & & na & & na & & na & & na & & na & & na & & na & \\
\hline cis-1,3-Dichloropropene & na & & na & & na & & na & & na & & na & & na & & na & \\
\hline 1,1,2-Trichloroethane & na & & na & & na & & na & & na & & na & & na & & na & \\
\hline Chlorodibromomethane & na & & na & & na & & na & & na & & na & & na & & na & \\
\hline Toluene & na & & na & & na & & na & & na & & na- & & na & & na & \\
\hline Tetrachloroethene & na & & na & & na & & na. & & na & & na & & na & & na & \\
\hline Chlorobenzene & na & & na & & na & & na & & na & & na & & na & & na & \\
\hline Elhylbenzene & na & & na & & na & & na & & na & & na & & na & & na & \\
\hline Total Xylene & na & & na & & na & & na & & na & & na & & na & & na & \\
\hline Bromoform & na & & na & & na & & na & & na & & na & & na & & na & \\
\hline 1,1,2,2-Tetrachloroethane & na & & na & & na & & na & & na & & na & & na & & na & \\
\hline
\end{tabular}


Appendix E

Pond Cleanup Verification Analytical Results

\begin{tabular}{|c|c|c|c|c|c|c|c|c|c|c|c|c|c|c|c|c|}
\hline IT Corp ID\# & RU-VSS-30 & & RU-VSS-31 & & RU-VSS-131 & & RU-VSS-32 & & RU-VSS-33 & & RU-VSS-34 & & RU-VSS-34-1 & & RU-VSS-34-2 & \\
\hline Date Collected & $10 / 12 / 95$ & & $10 / 12 / 95$ & & $10 / 12 / 95$ & & $10 / 12 / 95$ & & $10 / 12 / 95$ & & $10 / 12 / 95$ & & $10 / 18 / 95$ & & $10 / 21 / 95$ & \\
\hline Sample Location & Pond Floor & & Pond Floor & & Pond Floor & & Pond Floor & & Pond Floor & & Pond Floor & & Pond Floor & & Pond Floor & \\
\hline & Conc. & $\mathbf{Q}$ & Conc. & $\mathbf{Q}$ & Conc. & $\mathbf{Q}$ & Conc. & Q & Conc. & Q & Conc. & $\mathbf{Q}$ & Conc. & $\mathbf{a}$ & Conc. & Q \\
\hline $\mathrm{TPH}_{\mathrm{h}, \ldots}, \cdots$ & $\mathrm{mg} / \mathrm{kg}$ & $\because$ & $\mathrm{mg} / \mathrm{kg}$ & & mig/kg & 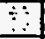 & $\mathrm{mg} / \mathrm{kg}$ & & $\mathrm{mg} / \mathrm{kg}$ & $\vdots$ & $\mathrm{mg} / \mathrm{kg} \mathrm{a}$ & 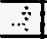 & $\mathrm{mg} / \mathrm{kg}$ & $\because$ & $\mathrm{mg} / \mathrm{kg}$ & \\
\hline Nonspecific & na & & na & & na & & na & & na & & na & & na & & na & \\
\hline Diesel & 36 & & 30 & $*$ & na & & 170 & & 340 & & 1,400 & & 1,700 & & 140 & \\
\hline Waste Oil & 25 & U & na & & na & & na & & na & & \begin{tabular}{|c|} 
na \\
\end{tabular} & & $\mathrm{na}$ & & na & \\
\hline METALS:(TCLP) & 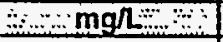 & : & mig/L: $\because \because$ & $\therefore$ & $\therefore \mathrm{mg} / \mathrm{L}:-$ & (i) & mgl & -1 & $\therefore \cdot \mathrm{mg} / \mathrm{L}_{\mathrm{K}} \mathrm{u}$ & 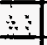 & mg/lis:man & $\therefore$ & mgl & ست.: & mig/L & \\
\hline Silver & 0.006 & U & na & & na & & na & & na & & \begin{tabular}{c|} 
na \\
\end{tabular} & & na & & na & \\
\hline Arsenic & 0.0377 & UJ & na & & na & & na & & na & & na & & na & & na & \\
\hline Barium & 1.32 & & na & & na & & na & & na & & na & & na & & na & \\
\hline Cadmium & 0.0045 & $\mathrm{U}$ & na. & & na & & na & & na & & na & & na & & na & \\
\hline Chromium & 0.0037 & $\mathrm{U}$ & na & & na & & na & & na & & na & & na & & na & \\
\hline Lead & 0.0382 & U & na & & na & & na & & na & & na & & na & & na & \\
\hline Selenium & 0.0426 & $\mathrm{U}$ & na & & na & & na & & na & & na & & na & & na & \\
\hline Mercury & 0.0001 & $\mathbf{U}$ & na & & na & & na & & na & & na & & na & & na & \\
\hline ORGANICS:(TCLP) & mg/hin & 2 & 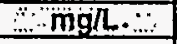 & 3 & 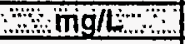 & :"1 & ang/t & $\because$ & $\mathrm{mg} / \mathrm{k}$ & $\because$ & 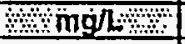 & 8 & ing/lising & . & :8wagh & $\therefore$ \\
\hline Chloromethane & na & & na & & na & & na & & na & & \begin{tabular}{|c|} 
na \\
\end{tabular} & & na & & na & \\
\hline Vinyl Chloride & na & & na & & na & & na & & na & & na & & na & & na & \\
\hline Bromomethane & na & & na & & na & & na & & na & & na & & na & & na & \\
\hline Chloroethan $\theta$ & na & & na & & na & & na & & na & & na & & na & & na & \\
\hline Acrolein & na & & na & & na & & na & & $\mathrm{na}$ & & na & E & na & & na & \\
\hline Acrylonitrile & na & & na & & na & & na & & na & & na & & na & & na & \\
\hline Methylene Chloride & na & & na & & na & & na & & na & & na & & na & & $\because \mathrm{na}$ & \\
\hline 1,1-Dichloroethene & na & & na & & na & & na & & na & & na & & na & & $\therefore$ na & \\
\hline trans-1,2-Dichloroethene & na & & na & & na & & na & & na & & na & & na & & $\sim$ na & \\
\hline 1,1-Dichloroethane & na & & na & & na & & na & & na & & na & & na & & $\cdots$ na & \\
\hline Chloroform - & na & & na & & na & & na & & na & & na & & na & & na & \\
\hline 1,2-Dichloroethane & na & & na & & na & & na & & na & & na & & na & & na & \\
\hline 1,1,1-Trichloroethane & na & & na & & na & & na & & na & & na & & na & & na & \\
\hline Carbon Tetrachloride & na & & na & & nia & & na & & na & & na & & na & & $-\mathrm{na}$ & \\
\hline Trichloroethene & na & & na & & na & & na & & na & & na & & na & & na & \\
\hline 1,2-Dichloropropane & na & & na & & na & & na & & na & & na' & & na & & . na & \\
\hline Benzene & 10 & U & 25 & $\mathrm{U}$ & na & & 25 & $\mathrm{U}$ & 25 & $\mathrm{U}$ & 25 & $U$ & na & & $\because$ na & \\
\hline 2-Chloroethylvinyl ether & na & & na & & na & & na & & na & & na & & na & & na & \\
\hline Bromodichloromethane & na & & na & & na & & na & & na & & na & & na & & na & \\
\hline trans-1,3-Dichloropropene & na & & na & & na & & na & & na & & na & & na & & na & \\
\hline cis-1,3-Dichloropropene & na & & na & & na & & na & & na & & na & & na & & na & \\
\hline 1,1,2-Trichloroethane & na & & na & & na & & na & & $\mathrm{na}$ & & na & & na & & na & \\
\hline Chlorodibromomethane & na & & na & & na & & na & & na & & na & & na & & - na & \\
\hline Toluene & na & & na & & na & & na & & na & & na & & na & & na & \\
\hline Tetrachloroethene & na & & na & & na & & na & & na. & & na & & na & & na & \\
\hline Chlorobenzene & na & & na & & na & & na & & na & & $\mathrm{na}$ & & na & & na & \\
\hline Elhylbenzene & na & & na & & na & & na & & na & & na & & na & & na & \\
\hline Total Xylene & na & & na & & na & & na & & na & & na & & na & & na & \\
\hline Bromoform & na & & na & & na & & na & & na & & na & & na & & $\overline{n a}$ & \\
\hline 1,1,2,2-Tetrachloroelhane & na & & na & & na & & na & & na & & na & & na & & na & \\
\hline
\end{tabular}


Appendix E

Pond Cleanup Verification Analytical Results

\begin{tabular}{|c|c|c|c|c|c|c|c|c|c|c|c|c|c|c|c|c|}
\hline IT Corp ID\# & RU-VSS-34-12 & & RU-VSS-35 & & RU-VSS-36 & & RU-VSS-37 & & RU-VSS-38 & & RU-VSS-40 & & RU-VSS-41 & & RU-VSS-42 & \\
\hline Date Collected & $10 / 14 / 95$ & & $10 / 13 / 95$ & & $10 / 12 / 95$ & & $10 / 12 / 95$ & & $10 / 12 / 95$ & & $10 / 12 / 95$ & & $10 / 13 / 95$ & & $10 / 13 / 95$ & \\
\hline Sample Location & Pond Floor & & Pond Floor & & Pond Floor & & Pond Floor & & Pond Floor & & Pond Floor & & Pond Floor & & Pond Floor & \\
\hline & Conc. & $\mathbf{Q}$ & Conc. & $\mathbf{Q}$ & Conc. & a & Conc. & a & Conc. & Q & Conc. & $\mathbf{Q}$ & Conc. & $\mathbf{Q}$ & Conc. & $\bar{Q}$ \\
\hline TPH: & $\mathrm{mg} / \mathrm{kg}$ & & $\mathrm{mg} / \mathrm{kg}$ & & $\mathrm{mg} / \mathrm{kg}$ & & $\mathrm{mg} / \mathrm{kg}$ & & $\mathrm{mg} / \mathrm{kg}$ & & $\mathrm{mg} / \mathrm{kg}$ & & $\mathrm{mg} / \mathrm{kg}$ & & $\mathrm{mg} / \mathrm{kg}$ & \\
\hline Nonspecilic & na & & na & & na & & na & & na & & na & & na & & na & \\
\hline Diesel & 310 & & 600 & & 590 & & 72 & & 540 & & 25 & $\bar{U}$ & 240 & & 49 & \\
\hline Waste Oil & na & & na & & na & & na & & na & & 25 & $\mathrm{U}$ & na & & na & \\
\hline METALS: (TCLP) & $\mathrm{mg} / \mathrm{L}$ & & $\mathrm{mg} / \mathrm{L}$ & & $m g / L$ & & $\mathrm{mg} / \mathrm{L}$ & & $\mathrm{mg} / \mathrm{L}$ & & $\mathrm{mg} / \mathrm{L}$ & & $\mathrm{mg} / \mathrm{L}$ & & $\mathrm{mg} / \mathrm{L}$ & \\
\hline Silver & 0.50 & $\bar{U}$ & .0 .50 & UJ & na & & na & & na & & 0.006 & U & 0.50 & UJ & na & \\
\hline Arsenic & 0.50 & $\mathrm{U}$ & 0.50 & $U$ & na & & na & & na & & 0.0377 & UJ & 0.50 & $\mathrm{U}$ & na & \\
\hline Barium & 10.0 & $\bar{U}$ & $\cdot 10.0$ & $\mathrm{U}$ & na. & & na & & na & & 1.16 & & 10.0 & $\bar{U}$ & na & \\
\hline Cadmium & 0.10 & $\bar{U}$ & 0.10 & $\mathrm{U}$ & na & & na & & na & & 0.0023 & $\bar{U}$ & 0.10 & $\bar{U}$ & na & \\
\hline Chromium & 0.10 & $\bar{U}$ & 0.10 & $\mathrm{U}$ & na & & na & & na & & 0.0058 & $\underline{U}$ & 0.10 & $\bar{U}$ & na & \\
\hline Lead & 0.50 & U & 0.50 & $\mathrm{U}$ & na & & na & & na & & 0.0382 & $\bar{U}$ & 0.50 & $\underline{U}$ & na & \\
\hline Selenium & 0.10 & $\bar{U}$ & $0 . \overline{10}$ & $\mathrm{U}$ & na & & na & & na & & 0.0426 & $\bar{U}$ & 0.10 & $\underline{U}$ & na & \\
\hline Mercury & 0.020 & $\mathrm{U}$ & 0.020 & $\mathrm{U}$ & na & & na & 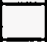 & na & & 0.0001 & $\mathrm{U}$ & 0.020 & $\bar{U}$ & na & \\
\hline ORGANICS: (TCLP) & $m g / L$ & & $\mathrm{mg} / \mathrm{L}$ & & miglts & & $m i g / L, \cdots$ & 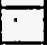 & $\because \mathrm{mg} / \mathrm{l}$ & \%: & \#; "mglt & $\vdots$ & $\mathrm{mg} / \mathrm{m}$ & $\therefore$ & $\mathrm{mg} / \mathrm{h}$ & \\
\hline Chlordmethane & na & & na & & na & & na & & na & & na & & na & & na & \\
\hline Vinyl Chloride & na & & na & & na & & na & & na & & na & & na & & na & \\
\hline Bromomethane & na & & na & & na & & na & & na & & na & & na & & na & \\
\hline Chloroethane & na & & na & & na & & na & & na & & na & & na & & na & \\
\hline Acroleln & na & & na & & na & & na & & na & & na & & na & & na & \\
\hline Acrylonitrile & na & & na & & na & & na & & na & 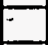 & na & & na & & na & - \\
\hline Methylene Chloride & na & & na & & na & & na & & na & & na & & na & & na & \\
\hline 1,1-Dichloroethene & na & & na & & na & & na & & na & & na & & na & & na & \\
\hline trans-1,2-Dichloroethene & na & & na & & na & & na & & na & & na & & na & & na & \\
\hline 1,1-Dichloroethane & na & & na & & na & & na & & na & & na & & na & & na & \\
\hline Chlorolorm & na & & na & & na & & na & & na & & na & & na & & na & \\
\hline 1,2-Dichloroethane & na & & na & & na & & na & & na & & na & & na & & na & \\
\hline 1,1,1-Trichloroethane & na & & na & & na & & na & & na & & na & & na & & na & \\
\hline Carbon Tetrachloride & na & & na & & na & & na & & na & & na & & na & & na & \\
\hline Trichloroelhene & na & & na & & na & & na & & na & & na & & na & & na & \\
\hline 1,2-Dichloropropane & na & & na & & na & & na & & na & & na & & na & & na & \\
\hline Benzene & 25 & $\mathrm{U}$ & 25 & $\mathrm{U}$ & 25 & $\mathrm{U}$ & 25 & U & 25 & $\mathrm{U}$ & 10 & $\bar{U}$ & 25 & U & 25 & $\bar{U}$ \\
\hline 2-Chloroethylvinyl ether & na & & na & & na. & & na & & na & & na & & na & & na & \\
\hline Bromodichloromelhane & na & & na & & na & & na & & na & & na & & na & & na & \\
\hline trans-1,3-Dichloropropene & na & & na & & na & & na & & na & & na & & na & & na & \\
\hline cis-1,3-Dichloropropene & - na & & na & & na & & na & & na & & na & & na & & na & \\
\hline 1,1,2-Trichloroethane & na & & na & & na & & na & & $\overline{\text { na }}$ & & na & & na & & na & \\
\hline Chlorodibromomethane & na & & na & & na & & na & & na & & na & & na & & na & \\
\hline Toluene & na & & na & & na & & na & & na & & na & & na & & na & \\
\hline Tetrachloroethene & na & & na & & na & & na & & na & & na & & na & & na & \\
\hline Chlorobenzene & na & & na & & na & & na & & na & & na & & na & & na & \\
\hline Ethylbenzene & na & & $\overline{\mathrm{na}}$ & & na & & na & & na & & $\overline{n a}$ & & na & & na & \\
\hline Total Xylene & $\overline{\text { na }}$ & & $\overline{\text { na }}$ & & na & & na & & na & & na & & na & & na & \\
\hline Bromoform & na & & $\overline{\text { na }}$ & & na & & na & & $\overline{n a}$ & & na & & na & & na & \\
\hline 1,1,2,2-Tetrachloroethane & na & & na & & na & & na & & na & & na & & na & & na & \\
\hline
\end{tabular}


Appendix $E$

Pond Cleanup Verification Analytical Results

\begin{tabular}{|c|c|c|c|c|c|c|c|c|c|c|c|c|c|c|c|c|}
\hline IT Corp ID\# & RU-VSS-43 & & RU-VSS-44 & & RU-VSS-45 & & RU-VSS-46 & & RU-VSS-47 & & RU-VSS-4B & & RU-VSS-49 & & RU-VSS-49-12 & \\
\hline Date Collected & $10 / 19 / 95$ & & $10 / 19 / 95$ & & $11 / 01 / 95$ & & $11 / 01 / 95$ & & $11 / 01 / 95$ & & $10 / 19 / 95$ & & $10 / 13 / 95$ & & $10 / 14 / 95$ & \\
\hline Sample Location & Pond Floor & & Pond Floor & & Pond Floor & & Pond Floor & & Pond Floor & & Pond Floor & & Pond Floor & & Pond Floor & \\
\hline. & Conc. & Q & Conc. - & $\mathbf{Q}$ & Conc. & $\mathbf{Q}$ & Conc. & $\mathbf{a}$ & Conc. & Q & Conc. & $\mathbf{Q}$ & Conc. & Q & Conc. & $\mathbf{Q}$ \\
\hline TPH: & $\mathrm{mg} / \mathrm{kg}$ & & $\mathrm{mg} / \mathrm{kg}$ & $\cdots$ & $\mathrm{mg} / \mathrm{kg}$ & & $\mathrm{mg} / \mathrm{kg}$ & & $\mathrm{mg} / \mathrm{kg}$ & & $\mathrm{mg} / \mathrm{kg}$ & & $\mathrm{mg} / \mathrm{kg}$ & & $\mathrm{mg} / \mathrm{kg}$ & \\
\hline Nonspecific & na & & na & & na & & na & & na & & $\mathrm{na}$ & & na & & na & \\
\hline Diesel & 170 & & 470 & & 45 & & 21 & & 67 & & 790 & & 110 & & 350 & \\
\hline Waste Oil & na & & na & & na & & na & & na & & na & & na & & na & \\
\hline METALS:(TCLP) & $\therefore m g / L$ & & $\mathrm{mg} / \mathrm{L}$ & & $\mathrm{mg} / \mathrm{L}$ & & $\mathrm{mg} / \mathrm{L}$ & & $\mathrm{mg} / \mathrm{L}$. & & $\mathrm{mg} / \mathrm{L}$ & & $\mathrm{mg} / \mathrm{L}$ & & $\mathrm{mg} / \mathrm{L}$ & \\
\hline Silver & na & & na & & na & & na & & 0.50 & $\mathrm{U}$ & na & & na & & 0.50 & $\bar{U}$ \\
\hline Arsenic & na & & na & & na & & na & & 0.50 & $\mathrm{U}$ & na & & na & & 0.50 & U \\
\hline Barium & na & & na & & na & & na & & 10.0 & $\mathrm{U}$ & na & & na & & 10.0 & $\bar{U}$ \\
\hline Gadmium & na & & na & & na & & na & & 0.10 & $\mathrm{U}$ & na & & na & & 0.10 & $\mathrm{U}$ \\
\hline Chromium & na & & na & & na & & na & & 0.10 & $\mathrm{U}$ & na & & na & & 0.10 & $\mathrm{U}$ \\
\hline Lead & na & & na & & na & & na & & 0.50 & $\bar{U}$ & na & & na & & 0.50 & $\mathrm{U}$ \\
\hline Selenium & na & & na & & na & & na & & 0.10 & $\mathrm{U}$ & na & & na & & 0.10 & $\bar{U}$ \\
\hline Mercury & na & & na & & na & & na & & 0.020 & $\mathrm{U}$ & na & & na & & 0.020 & U \\
\hline ORGANICS: (TCLP) & . mgin: & & $\operatorname{mg} / \mathbf{L}$ & $\vdots$ & mgll & & img/t.in & 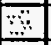 & $\mathrm{mg} / \mathrm{L}$ & 桨 & H. $\mathrm{mg} \boldsymbol{h}^{\prime}$ & & $\therefore m g / 2:$ & $\therefore$ & $\because \dot{\mathbf{m}} \mathbf{g} / \mathrm{L}$ & 4 \\
\hline Chloromethane & na & & na & & na & & na & 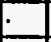 & na & & na & & na & & na & \\
\hline Vinyl Chloride & na & & na & & na & & na & & na & & na & & na & & na & \\
\hline Bromomethane & na & & na & & na & & na & & na. & & na & & na & & na & \\
\hline Chloroethane & na & & na & & na & & na & & na & & na & & na & & $\because \mathrm{na}$ & \\
\hline Acrolein & na & & na & & na & & na & & na & & na & & na & & na & \\
\hline Acrylonitrile & na & & na & & na & & na & & na & & na & & na & & na & \\
\hline Methylene Chloride & na & & na. & & na. & & na & & na & & na & & na & & na & \\
\hline 1,1-Dichloroethene & na & & na & & na & & na & & na & & na & & na & & na & \\
\hline trans-1,2-Dichloroelhene & na & & na & & na & & na & & na & & na & & na & & na & \\
\hline 1,1-Dichloroethane & $\mathrm{na}$ & & na & & na & & na & & na & & na & & na & & na & \\
\hline Chloroform & na & & na & & na & & na & & na & & na & & na & & na. & \\
\hline 1,2-Dichloroethane & na & & na & & na & & na & & na & & na & & na & & na & \\
\hline 1,1,1-Trichloroethane & na & & na & & na & & na & - & na & & na & & na & & na & \\
\hline Carbon Tetrachloride & na & & na & & na & & na & & na & & na & & na & & $\therefore$ na & \\
\hline Trichloroethene & na & & na & & na & & na & & na & & na & & na & & na & \\
\hline 1,2-Dichloropropane & na & & na & & na & & na & & na & & na & & na & & na & \\
\hline Benzene & 0.025 & $\mathrm{U}$ & 0.025 & $\mathbf{U}$ & 25 & $\mathrm{U}$ & 25 & U & 25 & U & 0.025 & $\mathrm{U}$ & 25 & U & 25 & $\mathrm{U}$ \\
\hline 2-Chloroethylvinyl ether & na & & na & & na & & na & & na & & na & & na & & na & \\
\hline Bromodichioromethane & na & & na & & na & & na & & na & & na & & na & & na & \\
\hline trans-1,3-Dichloropropene & na & & na & & na & & na & & na & & na & & na & & na & \\
\hline Cis-1,3-Dichloropropene & na & & na & & na & & na & & na & & na & & na & & na & \\
\hline 1,1,2-Trichloroethane & na & & na & & na & & na & & na & & na & & na & & na & \\
\hline Chlorodibromomethane & na & & na & & na & & na & & na & & na & & na & & na & \\
\hline Toluene & na & & na & & na & & na & & na & & na & & na & & na & \\
\hline Tetrachloroethene & na & & na & & na & & na & & na & & na & & na & & na & \\
\hline Chlorobenzene & na & & na. & & na & & na & & na & & na & & na & & na & \\
\hline Ethylbenzene & na & & na & & na & & na & & na & & na & & na & & na & \\
\hline Total Xylene & na & & na & & na & & na & & na & & na & & na & & na & \\
\hline Bromoform & na & & na & & na & & na & & na & & na & & na & & na & \\
\hline $1,1,2,2-$ Tetrachloroethane & na & & na & & na.. & & na & & na & & na & & na & & $n a$ & \\
\hline
\end{tabular}


Appendix E

Pond Cleanup Verification Analytical Results

\begin{tabular}{|c|c|c|c|c|c|c|c|c|c|c|c|c|c|c|}
\hline $\begin{array}{r}\text { IT Corp ID\# } \\
\text { Date Collected }\end{array}$ & RU-VSS-49-12S & & RU-VSS-50 & & RU-VSS-51 & & RU-VSS-52 & & RU-VSS-53 & & RU-VSS-54 & & RU-VSS-55 & \\
\hline Date Collected & $10 / 14 / 95$ & & $10 / 13 / 95$ & & $10 / 12 / 95$ & & $10 / 12 / 95$ & & $11 / 6 / 95$ & & $11 / 6 / 95$ & & $11 / 6 / 95$ & \\
\hline Sample Location & Pond Floor & & Pond Floor & & Pond Floor & & Pond Floor & & Pond Floor & & Pond Floor & & Pond Floor & \\
\hline & Conc. & $Q$ & Conc. & Q & Conc. & $\mathbf{Q}$ & Conc. & Q & Conc. & Q & Conc. & $a$ & Conc. & $\bar{a}$ \\
\hline TPH::- & $\mathrm{mg} / \mathrm{kg}$ & $\because:$ & $\mathrm{mg} / \mathrm{kg}$ & & $\mathrm{mg} / \mathrm{kg}$ & $\because$ & $\mathrm{mg} / \mathrm{kg}$ & & $\mathrm{mg} / \mathrm{kg}$ & & $\dot{m g} / \mathrm{kg}$ & & $\mathrm{mg} / \mathrm{kg}$ & \\
\hline \begin{tabular}{|l} 
Nonspecific \\
\end{tabular} & na & & na & 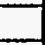 & na & & na & & na & & na & & na & \\
\hline \begin{tabular}{|l|} 
Diesel \\
\end{tabular} & 120 & & 1,000 & & 60 & & 2.4 & $\bar{U}$ & 27 & & 60 & & 38 & \\
\hline Waste Oil & 25 & $\mathrm{U}$ & na & E & 25 & $\bar{U}$ & na & & na & & na & & na & \\
\hline METALS: (TCLP) $:, \because \ldots$ & $\therefore \mathrm{mg} / \mathrm{L}$ & & $\mathrm{mg} / \mathrm{L}$ & - & $\therefore \mathrm{mg} / \mathrm{a}$ & 3 & $\therefore \ldots \mathrm{mg} / \mathrm{L} \cdot \cdots$ & $\because$ & mg/L & 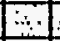 & $\mathrm{mg} / \mathrm{L}$ & 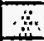 & $\mathrm{mg} / \mathrm{L}$ & \\
\hline Silver & 6.0 & $\tilde{U}$ & 0.50 & UUJ & na & Z & na & . & na & & na & & na & \\
\hline Arsenic & 37.7 & $\bar{U}$ & 0.50 & $\bar{U}$ & na & Z & na & & na & & na & & na & \\
\hline Barium & 1480 & & 10.0 & $\mathrm{U}$ & na & - & na & & na & & na & . & na & \\
\hline Cadmium & 2.3 & U & 0.10 & $\mathrm{U}$ & na & 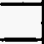 & na & & na & & $\mathrm{na}$ & & na & \\
\hline Chromium & 4.8 & $B$ & 0.10 . & U & na & 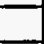 & na & 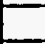 & na & - & na & & na & - \\
\hline Lead & 38.2 & $\bar{U}$ & 0.50 & $\mathrm{U}$ & na & 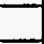 & na & & na & & na & & na & \\
\hline Selenium & 58.8 & $\mathrm{~B}$ & 0.10 & $\bar{U}$ & na & 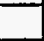 & na & & na & & na & & na & \\
\hline Mercury $\quad \cdot$ & 0.10 & $\bar{U}$ & 0.020 & $\mathrm{U}$ & na & E & na & & na & & na & & na & \\
\hline OHGANICS OTCLP) $\ldots$ & $m \ddot{g} / \mathrm{h}$ & $\because$ & $\therefore m g h$ & $\because$ & $\therefore$ migh & $\because \because$ & ing/h & $\vdots$ & : mgll & $\therefore$ & $\mathrm{mg} / \mathrm{L} \cdot \mathrm{a}$ & & imgll & \\
\hline Chloromethane & na & & na & -1 & na & & $\mathrm{na}$ & 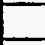 & na & & na & & na & \\
\hline Vinyl Chloride & na & & na & E & na & - & na & & na & & na & & na & \\
\hline Bromomethane & na & & na & 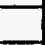 & na & Z & na & & na & & na & & na & \\
\hline Chloroethane & na & & na & - & na & - & na & & na & & na & & na & \\
\hline Acrolein & na & & na & 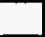 & na & 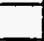 & na & & na & & na & & na & \\
\hline Acrylonitrile & na & & na & E & $\mathrm{na}$ & - & na & & na & & na & & na & \\
\hline Methylene Chloride & na & & na & E & na & - & na & & na & & na & & na & \\
\hline 1,1-Dichloroethene & na & & na & - & na & E & na & & na & & na & & na & \\
\hline trans-1,2-Dichloroethene & na & & na & 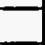 & na & Z & na & & na & & na & & na & \\
\hline 1,1-Dichloroethane & na & & na & 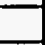 & na & 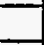 & na & & na & - & na & & na & \\
\hline Chloroform & na & 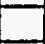 & na & - & na & - & na & & na & & na & & na & \\
\hline 1,2-Dichloroethane & na & & na & - & na & - & na & & na & & na & & na & \\
\hline 1,1,1-Trichloroethane & na & & na & - & na & 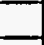 & na & & na & - & na & & na & \\
\hline Carbon Tetrachloride & na & & na & & na & & na & & na & & na & & na & \\
\hline $\begin{array}{l}\text { Trichloroethene } \\
\end{array}$ & na & - & na & 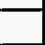 & na & 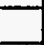 & na & 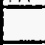 & na & 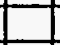 & na & 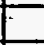 & na & \\
\hline 1,2-Dichloropropane & na & & na & & na & & na & & na & & na & & na & \\
\hline Benzene & 10 & $U$ & 25 & $U$ & 10 & $\bar{U}$ & 25 & $U$ & 25 & $U$ & 25 & $\mathrm{U}$ & 25 & $U$ \\
\hline 2-Chloroethylvinyl elher & na & & na & & na & & na & & na & & na & & na & \\
\hline Bromodichloromethane & na & 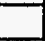 & na & & na & & na & & na & & na & & na & \\
\hline Irans-1,3-Dichloropropene & na & & na & & na & & na & & na & & na & & na & \\
\hline cis-1,3-Dichloropropene & na & & na & & na & & na & & na & & na & & na & \\
\hline 1,1,2-Trichloroethane & $\mathrm{na}$ & & na & & na & & na & & $\mathrm{na}$ & & na & & na & \\
\hline Chlorodibromomethane & na & & na & & na & & na & & na & & na & & na & \\
\hline Toluene & na & & na & & na & & na & & na & & na & & $\mathrm{na}^{-}$ & \\
\hline Tetrachloroethene & na & & na & & na & & na & & na & & na & & na & \\
\hline Chlorobenzene & na & 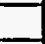 & na & & na & & $\mathrm{na}$ & & na & & na & & na & \\
\hline Ethylbenzene & na & & na & & na & & na & & na & 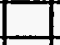 & na & & na & \\
\hline Total Xylene & na & & na & & na & & na & & na & & na & & na & \\
\hline Bromoform & na & & $\mathrm{na}$ & & na & & na & & na & 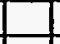 & na & & na & \\
\hline 1,1,2,2-Tetrachloroethane & na & & na & & na & & na & & na & & na & & na & \\
\hline
\end{tabular}


Appendix E

Pond Cleanup Verification Analytical Results

\begin{tabular}{|c|c|c|c|c|c|c|c|c|c|c|c|c|c|c|}
\hline IT Corp ID\# & RU-VSS-T01 & & RU-VSS-T01-07 & & RU-VSS-TO1-19 & & AU-VSS-T02-15.5 & & RU-VSS-T02-23 & & RU-VSS-T02-31.5 & & RU-VSS-T03-26 & \\
\hline Date Collected & $9 / 21 / 95$ & & $9 / 21 / 95$ & & $9 / 21 / 95$ & & $9 / 20 / 95$ & & $9 / 20 / 95$ & & $9 / 20 / 95$ & & $9 / 20 / 95$ & \\
\hline Sample Locallon & Test Pit 01 & & Test Pit 01 & & Test Pit 01 & & Test Pit 02 & & TestPit 02 & & Test Pit 02 & & Test Pit 03 & \\
\hline & Conc. & Q & Conc. & $\mathbf{Q}$ & Conc. & $\mathbf{Q}$ & Conc. & $\mathbf{a}$ & Conc. & $\mathbf{Q}$ & Conc. & $\mathbf{Q}$ & Conc. & $\mathbf{Q}$ \\
\hline TPHI $=4, \therefore \quad \therefore$ & $\mathrm{mg} / \mathrm{kg}$ & 4 & $\mathrm{ing} / \mathrm{kg}$ & & $\ldots$ mig/kg & 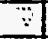 & $\operatorname{mg} / \mathrm{kg}$ & & mg/kg $:$ & & $\because: \mathrm{mg} / \mathrm{kg} \ldots$ & $\%$ & $\mathrm{mg} / \mathrm{kg}$ & \\
\hline Nonspecific & na & & na & & na & & na & & na & & na & & na & \\
\hline Diesel & na & & 300 & & 330 & & 20 & & 40 & & 4.4 & & 56 & \\
\hline Waste Oil & na & & na & & na & & na & & $\mathrm{na}$ & & na & & na & \\
\hline METALS (TCLP) & ing mg/L & $\because i$ & $\because \mathrm{mg} / \mathrm{L}$ & $\vdots$ & $\because \mathbf{m g} / \mathbf{L}: \cdots$ & $\ldots$ & $\because \quad \therefore$ mg/L $: \cdots$ & & $3 \mathrm{mg} / \mathrm{L} / \mathrm{m}$ & $\because$ & mg/L & $\because$ & mgll & \\
\hline Silver & 0.50 & $\mathrm{U}$ & na & & na & & na & & na & & na & & na & \\
\hline Arsenic & 0.50 & U & na & & na & & na & & na & & na & & na & \\
\hline Barium & 10.0 & $\mathbf{U}$ & na & & na & & - na & & na & & na & & na & \\
\hline Cadmium & 0.10 & $\mathrm{U}$ & na & & na & & na & & na & & na & & na & \\
\hline Chromium & 0.10 & $\mathrm{U}$ & na & & na & & . na & & na & & na & & na & \\
\hline Lead & 0.50 & $\mathrm{U}$ & na & & na & & na & & na & & na & & na & \\
\hline Selenium & 0.10 & $\mathrm{U}$ & na & & na & & na & & na & & nia & & na & \\
\hline Mercury & 0.020 & $\mathrm{U}$ & na & & na & & na & & na & & na & & na & \\
\hline ORGANIGS:(TCLP) & $\because \mathbf{m g} / \mathrm{h}$ & $\therefore$ & $m g / t=$ & $\because$ & angland & $\because$ & mg/lo: & & 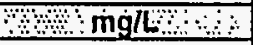 & $\vdots$ & $\because \mathrm{mg} / \mathrm{h}: \mathrm{n}$ & $\because$ & $=2 \mathrm{mg} / \mathrm{L}$ & \\
\hline Chloromethane & na & & na & & na & & na & & na & & na & & na & \\
\hline Vinyl Chloride & na & & na & & na & & na & & na & & na & & na & \\
\hline Bromomethane & na & & na & & na & & na & & na & & na & & na & \\
\hline Chloroethane & na & & na & & na & & na & & na & & na & & na & \\
\hline Acrolein & na & & na & & na & & na & & na & & na & & na & \\
\hline Acrylonitrile & na & & na & & na & & na & & na & & na & & na & \\
\hline Methylene Chloride & na & & na & & na & & na & & na & & na & & na & \\
\hline 1,1-Dichloroethene & na & & na & & na & & na & & na & & na & & na & \\
\hline trans-1,2-Dichloroethene & na & & na & & na & & na & & na & & na & & na & \\
\hline 1,1-Dichloroethane & na & & na & & na & & na & & na & & na & & na & \\
\hline Chloroform & na & & na & & na & & na & & na & & na & & na & \\
\hline 1,2-Dichloroethane & na & & na & & na. & & na & & na & & na & & na & \\
\hline 1,1,1-Trichloroethane & na & & na & & na & & na & & na & & na & & na & \\
\hline Carbon Tetrachloride & na & & na & & na & & na & & na & & na & & na & \\
\hline Trichloroelhene & na & & na & & na & & na & & na & & na & & na & \\
\hline 1,2-Dichloropropane & na & & na & & na & & na & & na & & na & & na & \\
\hline Benzene & ND & & na & & na & & na. & & na & & na & & na & \\
\hline 2-Chloroethylvinyl elher & na & & na & & na & & na & & na & & na & & na & \\
\hline Bromodichloromelhane & na & & na & & na & & na & & na & & na & & na & \\
\hline trans-1,3-Dichloropropene & na & & na & & na & & na & & na & & na & & na & \\
\hline cis-1,3-Dichloropropene & na & & na & & na & & na & & na & & na & & na & \\
\hline 1,1,2-Trichloroothane & na & & na & & na & & na & & na & & na & & na & \\
\hline Chlorodibromomethane & na & & na & & na & & na & & na & & na & & na & \\
\hline Toluene & na & & na & & na & & na & & na & & na & & na & \\
\hline Tetrachloroethene & na & & na & & na & & na & & na & & na & & na & \\
\hline Chlorobenzene & na & & na & & na & & na & & na & & na & & na & \\
\hline Ethylbenzene & na & & na & & na & & na & & na & & na & & na & \\
\hline Tolal Xylene & na & & na & & na & & na & & na & & na & & na & \\
\hline Bromoform & na & & na & & na & & na & & na & & na & & na & \\
\hline 1,1,2,2-Tetrachloroethane & na & & na & & na & & na & & na & & na & & na & \\
\hline
\end{tabular}


Appendix $E$

Pond Cleanup Verification Analytical Results

\begin{tabular}{|c|c|c|c|c|c|c|c|c|c|c|c|c|c|c|}
\hline IT Corp ID\# & RU-VSS-T03-39 & & RU-VSS-TO4 & & RU-VSS-T04-14 & & AU-VSS-T04-23 & & RU-VSS-TO5-14 & & RU-VSS-T05-24 & & RU-VSS-T05-30 & \\
\hline Date Collected & $9 / 20 / 95$ & & $9 / 21 / 95$ & & $9 / 21 / 95$ & & $9 / 21 / 95$ & & $9 / 26 / 95$ & & $9 / 26 / 95$ & & $9 / 26 / 95$ & \\
\hline Sample Locatlon & Test Pit 03 & & Test Pit.04 & & Test Pit 04 & & Test Pit 04 & & Tesi Pit 05 & & Tes! Pit 05 & & Test Pit 05 & \\
\hline & Conc. & $\mathbf{Q}$ & Conc. & Q & Conc. & $\mathbf{Q}$ & Conc. & $\mathbf{Q}$ & Conc. & Q & Conc. & $\bar{Q}$ & Conc. & Q \\
\hline TPH: & $\mathrm{mg} / \mathrm{kg}$ & & $\mathrm{mg} / \mathrm{kg}$ & & $\mathrm{mg} / \mathrm{kg}$ & & $\mathrm{mg} / \mathrm{kg}$ & & $\mathrm{mg} / \mathrm{kg}$ & & $\mathrm{mg} / \mathrm{kg}$ & . & $\mathrm{mg} / \mathrm{kg}$ & \\
\hline Nonspecific & na & & na & & na & & na & & na & & na & & na & \\
\hline Diesel & 41 & & na & & 3,500 & & 3,100 & & 200 & & 14 & & 2.5 & $\bar{U}$ \\
\hline Waste Oil & na & & na & & na & & na & & na & & na & & na & \\
\hline METALS:(TCLP) . . & $\mathrm{mg} / \mathrm{L}$ & & $m g / t$ & & $\mathrm{mg} / \mathrm{L}$ & & $\mathrm{mg} / \mathrm{L}$ & & $\mathrm{mg} / \mathrm{L}$ & & $m g / L$ & & $m g / L$ & \\
\hline Silver & na & & 0.50 & U & na & & na & & na & 1 & na & & na & \\
\hline Arsenic & na & & 0.50 & U & na & & na & & na & & na & & na & \\
\hline Barium & na & & 10.0 & $\bar{U}$ & na & & na & & na & & na & & na & \\
\hline Cadmium & na & & 0.10 & $\bar{U}$ & na & & na & & na & & na & & na & \\
\hline Chromium & na & & 0.10 & $\bar{u}$ & na & & na & & na & & na & & na & \\
\hline Lead & na & & 0.50 & Uं & na & & na & & na & & na & & na & \\
\hline Selenium & na & & 0.10 & $\bar{U}$ & na & & na & & na & & na & & na & \\
\hline Mercury & na & & 0.020 & $\bar{U}$ & na & & na & & na & & na & & na & \\
\hline OAGANICS: (TCLP) & $\mathrm{mg} / \mathrm{L}:$ & & mg/h & $:$ & $\because \mathrm{mg} / \mathrm{L}$ & & $m g h$. & $\because$ & ing/h & 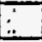 & mgillin & 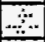 & Uimg/L.... & \\
\hline Chloromethane & na & & na & & na & & na & & na & & $\mathrm{na}$ & & na & \\
\hline Vinyl Chloride & na & & na & & na & & na & & na & & na & & na & \\
\hline Bromomelhane & na & & na & & na & & na & & na & & na & & na & \\
\hline Chloroethane & na & & na & & na & & na & & na & & na & & na & \\
\hline Acrolein & na & & na & & na & & na & & na & & na & & na & \\
\hline Acrylonitrile & na & & na & & na & & na & & na & & na. & & $\mathrm{na}$ & \\
\hline Methylene Chloride & na & & na & & na & & na & & na & & na & & na & \\
\hline 1,1-Dichloroethene & na & & na & & na & & na & & na & & na & & na & \\
\hline trans-1,2-Dichloroethene & na & & na & & na & & na & & na & & na & & na & \\
\hline 1,1-Dichloroethane & na & & na & & na & & na & & na & & na & & na & \\
\hline Chloroform & na & & na & & na & & na & & $\mathrm{na}$ & & na & & na & \\
\hline 1,2-Dichloroethane & na & & na & & na & & na & & na & & na & & na & \\
\hline 1,1,1-Trichloroethane & na. & & na & & na & & na & & na & & na & & na & \\
\hline Carbon Tetrachloride & na & & na & & na & & na & & na & & na & & na- & \\
\hline Trichloroethene & na & & na & & na & & na & & na & & na & & na & \\
\hline 1,2-Dichloropropane & na & & na & & na & & na & & na & & na & & na & \\
\hline Benzene & na & & $\mathrm{ND}$ & & na & & na & & $\mathrm{na}$ & & na & & na & \\
\hline 2-Chloroethylvinyl ether & na & & na & & na & & na & & na & & na & & na & \\
\hline Bromodichloromethan $\theta$ & na & & na & & na & & na & & na & & na & & na & \\
\hline trans-1,3-Dichloropropene & na & & na & & na & & na & & na & & na & & na & \\
\hline cis-1,3-Dichloropropene & na & & na & & na & & na & & na & & na & & na & \\
\hline 1,1,2-Trichloroethane & na & & na & & na & & na & & na & & na & & na & \\
\hline Chlorodibromomethane & na & & na & & na & & na & & na & & na & & na & \\
\hline Toluene & na & & na & & na & & na & & na & & na & & na & \\
\hline Tetrachloroethene & na & & na & & na & & na & & na & & na & & na & \\
\hline Chlorobenzene & na & & na & & na & & na & & na & & na & & na & \\
\hline Ethylbenzene & na & & na & & na & & na & & - na & & na & & na & \\
\hline Tolal Xylene & na & & na & & na & & na & & na & & na & & na & \\
\hline Bromoform & na & & na & & na & & na & & na & & na & & na & \\
\hline $1,1,2,2-$ Tetrachloroethane & na & & na & & na & & na & & na & & na & & na & \\
\hline
\end{tabular}


Appendix E

Pond Cleanup Verification Analytical Results

\begin{tabular}{|c|c|c|c|c|c|c|c|c|c|c|c|c|c|c|c|c|}
\hline IT Corp IDHI & RU-VSS-T06-7 & & RU-VSS-T06-15 & & RU-VSS-T06-22 & & RU-VSS-205 & & RU-VSS-215 & & RU-VSS-225 & & RU-VSS-227 & & RU-VSS-235 & \\
\hline Date Collected & $9 / 26 / 95$ & & $9 / 26 / 95$ & & $9 / 26 / 95$ & & $10 / 13 / 95$ & & $10 / 13 / 95$ & & $10 / 13 / 95$ & & $10 / 14 / 95$ & & $10 / 13 / 95$ & \\
\hline Sample Location & Test Pit 06 & & Test Pit 06 & & Test Pit 06 & & Pond Floor & & Pond Floor & & Pond Floor & & Pond Floor & & Pond Floor & \\
\hline & Conc. & Q & Conc. & $\mathbf{a}$ & Conc. & $\mathbf{Q}$ & Conc. & $\mathbf{a}$ & Conc. & $\mathbf{Q}$ & Conc. & a & Conc. & $Q$ & Conc. & $\mathbf{Q}$ \\
\hline TPH: & $\mathrm{mg} / \mathrm{kg}$ & & $\mathrm{mg} / \mathrm{kg}$ & & $\mathrm{mg} / \mathrm{kg}$ & & $\mathrm{mg} / \mathrm{kg}$ & & $\mathrm{mg} / \mathrm{kg}$ & & $\mathrm{mg} / \mathrm{kg}$ & $\bar{\vdots}$ & $\mathrm{mg} / \mathrm{kg}$ & $\therefore$ & $\mathrm{mg} / \mathrm{kg}$ & \\
\hline Nonspecific & na & & na & & na & & na & & na & & na & & na & & na & \\
\hline \begin{tabular}{|l|} 
Diesel \\
\end{tabular} & 23 & & 45 & & 2.1 & U & 30 & & 240 & & 500 & & 170 & & 440 & \\
\hline Wasle Oil & na & & na & & na & & 25 & $\mathrm{U}$ & 25 & $\bar{U}$ & 24 & $\mathrm{U}$ & na & & 25 & $\bar{U}$ \\
\hline METALS: (TCLP) & $\mathrm{mg} / \mathrm{L}$ & & $\mathrm{mg} / \mathrm{L}$ & & $\mathrm{mg} / \mathrm{L}$ & & $\mathrm{mg} / \mathrm{h}:$ & & $\mathrm{mg} / \mathrm{L}$ & $\overline{3}$ & $\mathrm{mg} / \mathrm{L}:$ & $\because$ & $\mathrm{mg} / \mathrm{L} \quad \therefore$ & & $\mathrm{mg} / \mathrm{L}$ & \\
\hline Silver & na & & na & & na & & 0.01 & $\mathrm{U}$ & 0.01 & $\bar{u}$ & 0.01 & $\bar{U}$ & 0.50 & $\bar{U}$ & 0.01 & $\bar{U}$ \\
\hline Arsenic & na & & na & & na & & 0.5 & $\bar{U}$ & 0.5 & $\bar{U}$ & 0.5 & $\bar{U}$ & 0.50 & $\bar{U}$ & 0.5 & $\bar{U}$ \\
\hline Barium & na & & na & & na & & 1.28 & & 1.04 & & 1.81 & & 10.0 & $\bar{U}$ & 2.07 & \\
\hline Cadmium & na & & na & & na & & 0.05 & $\bar{U}$ & 0.0063 & & 0.0105 & & 0.10 & $\bar{U}$ & 0.007 & \\
\hline Chromium & na & & na & & na & & 0.02 & $\bar{U}$ & 0.02 & $\bar{U}$ & 0.0218 & & 0.10 & $\bar{U}$ & 0.02 & $\bar{U}$ \\
\hline Lead & na & & na & & na & & 0.1 & $\bar{U}$ & 0.1 & $\bar{U}$ & 0.1 & $\bar{U}$ & 0.50 & $\overline{\mathrm{U}}$ & 0.1 & $\bar{U}$ \\
\hline Selenium & na & & na & & na & & 0.25 & $\bar{U}$ & 0.25 & $\bar{U}$ & 0.25 & $\bar{U}$ & 0.10 & $\bar{U}$ & 0.25 & $\bar{U}$ \\
\hline Mercury & na & & na & & na & & 0.0002 & $\bar{U}$ & 0.0002 & $\bar{U}$ & 0.0002 & $\bar{U}$ & 0.020 & $\bar{U}$ & 0.0002 & $\bar{U}$ \\
\hline ORGANIGS (TCLP) & ing n & 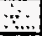 & $\mathrm{mg} / \mathrm{h}$ & 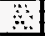 & $\because n$ m & $\therefore$ & mg/thi: w & $\therefore$ & ing/lous & 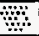 & $\mathrm{mg} / \mathrm{lm}$ & 3 & 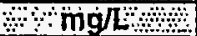 & 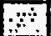 & mg/lo: & $\because ;$ \\
\hline Chloromethane & na & & na & & na & & na & & na & & na & . & na & 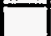 & na & \\
\hline Vinyl Chloride & na & & na & & na & & na & 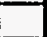 & na & & na: & & na & & na & \\
\hline Bromomethane & na & & na & & na & & na & . & na & & na & & na & & na & \\
\hline Chloroethane & na & & na & & na & & na & & na & & na & & na & & na & \\
\hline Acrolein & na & & na & & na & & na & & na & & na & & na & & na & \\
\hline Acrylonitrile & na & & na & & na & & na & & na & & na & & na & & na & \\
\hline Methylene Chloride & na & & na & & na & & na & & na & & na & & na & & na & \\
\hline 1,1-Dichloroethene & na & & na & & na & . & na & & na & & na & & na & & na & \\
\hline trans-1,2-Dichloroelhene & na & & na & & na & & na & & na & & na & & na & & na & \\
\hline 1,1-Dichloroethane & na & & na & & na & & na & & na & & na & & na & & na & \\
\hline Chloroform & na & & na & & na & 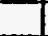 & na & & na & & na & & na & & na & \\
\hline 1,2-Dichloroethane & na & & na & & na & & na & & na & & na & & na & & na & \\
\hline 1,1,1-Trichloroethane & na & & na & & na & & na & & na & & na & . & na & & na & \\
\hline Carbon Tetrachloride & na & & na & & na & & na & & na & & na & & na & & na & \\
\hline Trichloroethene & na & & na & & na & & na & & na & . & na & & na & & na & \\
\hline 1,2-Dichloropropane & na & & na & & na & & na & & na & & na & & na & & na & \\
\hline Benzene & na & & na & & na & & 10 & $\mathbf{U}$ & 10 & $\mathrm{U}$ & 10 & $\mathrm{U}$ & 25 & U & 10 & $\bar{U}$ \\
\hline 2-Chloroethyivinyl ether & na & & na & & na & & na & & na & & na & & na & & na & \\
\hline Bromodichloromethane & na & & na & & na & & na & & na & $\cdot$ & na & & na & & na & \\
\hline trans-1,3-Dichloropropene & na & & na & & na & & na & & na & & na & & na & & na & \\
\hline cis-1,3-Dichloropropene & na & & na & & na & & na & & na & & na & & na & & na & \\
\hline 1,1,2-Trichloroethane & na & & na & & na & & na & & na & & na & & na & & na & \\
\hline Chlorodibromomethane & na & & na & & na & & na & & na & & na & & na & & na & \\
\hline Toluene & na & & na & & na & & na & & na & & na & & na & & na & \\
\hline Tetrachloroethene & na. & & na & & na & & na & . & na & & na & & na & & na & \\
\hline Chlorobenzene & na & & na & & na & & na & & na & & na & & na & & na & \\
\hline Elhylbenzene & na & & na & & na & & na & & na & & na & & na & & na & \\
\hline Total Xylene, & na & & na & & na & & na & & na & & na & & na & & na & \\
\hline Bromoform & na & & na & & na & & na & & na & & na & & na & & na & \\
\hline $1,1,2,2 \cdot$ Tetrachloroethan $\theta$ & na & & na & & na & & na & & na & & na & & na & & na & \\
\hline
\end{tabular}


Appendix E

Pond Cleanup Verification Analytical Results

\begin{tabular}{|c|c|c|c|c|c|c|c|c|}
\hline IT Corp ID\# & RU-VSS-241 & & RU-VSS-247 & & RU-VSS-253 & & RU-VSS-255 & \\
\hline Date Collected & $10 / 13 / 95$ & & $11 / 1 / 95$ & & $11 / 6 / 95$ & & $11 / 6 / 95$ & \\
\hline Sample Locatlon & Pond Floor & & Pond Floor & & Pond Floor & & Pond Floor & \\
\hline & Conc. & a & Conc. & $\mathbf{Q}$ & Conc. & $\mathbf{Q}$ & Conc. & $\mathbf{Q}$ \\
\hline TPH: $\ldots$ & mg/kg & & $\ddot{\mathrm{m} g} \mathrm{~g} / \mathrm{kg}$ & & $\mathrm{mg} / \mathrm{kg}$ & 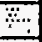 & $\therefore \mathrm{mg} / \mathrm{kg}$ & $\because$ \\
\hline Nonspecific & na & & na & & na & & na & \\
\hline Diesel & 380 & & 45 & & 25 & U & 25 & $\bar{U}$ \\
\hline Waste Oil & 24 & $\mathrm{U}$ & 24 & U & 25 & $\bar{U}$ & 25 & $\bar{U}$ \\
\hline METALS:(TCLP): & $\mathrm{mg} / \mathrm{L}=$ & $\because$ & $\because \mathrm{mg} / \mathrm{L}$ & 1 & $\therefore \mathrm{mg} / \mathrm{L}$ & $\because$ & mg/L & $\because$ \\
\hline Silver & 0.01 & $\mathrm{U}$ & 0.01 & $\mathrm{U}$ & na & & na & \\
\hline Arsenic & 0.5 & U & 0.50 & U & na & & na & \\
\hline Barium & 1.67 & & 0.94 & & na & & na & \\
\hline Cadmium & 0.0054 & & 0.0030 & B & na & & na & \\
\hline Chromium & 0.02 & U & 0.020 & U & na & & na & \\
\hline Lead & 0.1 & $\mathrm{U}$ & 0.10 & $\underline{U}$ & na & & na & \\
\hline Selenium & 0.25 & $\mathrm{U}$ & 0.25 & $\mathbf{U}$ & na & & na & \\
\hline Mercury & 0.0002 & $\mathrm{U}$ & 0.00010 & B & na & & na & \\
\hline ORGANICS: (TCLP) : : & $\mathrm{mg} / \mathrm{l}$ & $\dot{4}$ & . mig/lo............ & 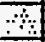 & 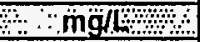 & 3 & 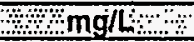 & 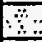 \\
\hline Chloromethane & na & & na & & na & & na & \\
\hline Vinyl Chloride & na & & na & & na & & na & \\
\hline Bromomethane & na & & na & & na & & na & \\
\hline Chloroethane & na & & na & & na & & na & \\
\hline Acrolein & na & & na & & na & & na & \\
\hline Acrylonitrile - & na & & na & & na & & na & \\
\hline Methylene Chloride & na & & na & & na & & na & \\
\hline 1,1-Dichloroethene & na & & na & & na & & na & \\
\hline trans-1,2-Dichloroethene & na & & na & & na & & na & \\
\hline 1,1-Dichloroethane & na & 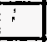 & na & & na & & na & \\
\hline Chloroform & na & & na & & na & & ná & \\
\hline 1,2-Dichloroethane & na & & na & & na & & na & \\
\hline 1,1,1-Trichloroelhane & na & & na & & na & & na & \\
\hline Carbon Tetrachloride & na & & na & & na & $\cdot$ & na & \\
\hline Trichloroethene & na & & na & & na & & na & \\
\hline 1,2-Dichloropropane & na & & na & & na & & na & \\
\hline Benzene & 10 & $\mathrm{U}$ & 10 & $\mathrm{U}$ & 10 & $\mathrm{U}$ & 10 & $\bar{U}$ \\
\hline 2-Chloroethylvinyl ether & na & & na & & na & & na & \\
\hline Bromodichloromethane & na & & na & & na & & na & \\
\hline trans-1,3-Dichloropropene & na & & na & - & na & & na & \\
\hline cis-1,3-Dichloropropene - & na & & na & & na & & na & \\
\hline 1,1,2-Trichloroethane & na & & na & & na & & na & \\
\hline Chlorodibromomethane & na & & na & & na & & na & $\dot{\cdot}$ \\
\hline Toluene & na & & na & & na & & na & \\
\hline Tetrachloroethene & na & & na & & na & & na & \\
\hline Chlorobenzene & na & & na & & na & & na & \\
\hline Ethylbenzene & na & & na & & na & & na & \\
\hline Total Xylene & na & & na & & na & & na & \\
\hline Bromoform & na & & na & & na & & na & \\
\hline 1,1,2,2-Tetrachloroethane & na & & na & & na & & na & \\
\hline
\end{tabular}




\section{$Q=$ Data qualifier.}

$=$ Compound was analyzed but not detected above the specilied limil

$B=$ In organics, the analyte was lound in the blank In Inorganics, the resull is above the Instrument Detection Limll but below the Contract Required Delection Linit

$\mathrm{N}=$ Presumptive identillcatlon of a tentatively idenilied compound based on a mass spectral library search.

$\mathrm{mg} / \mathrm{kg}=$ milligrams per kllogram

$m g h=$ milligrams per liter

ul $=$ micrograms per liter

Matrix Interleience experlenced with this analysis

$\mathrm{D}=\mathrm{TPH}$ Dlesel concentration lor RU.VSS -13 is from a 1:5 dilution.

na $=$ nol analyzed

ND = parameter was analyzed for but not delected.

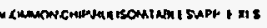





\section{Appendix F}

Surface Ground Zero Area Soil Boring Logs 


\section{.}




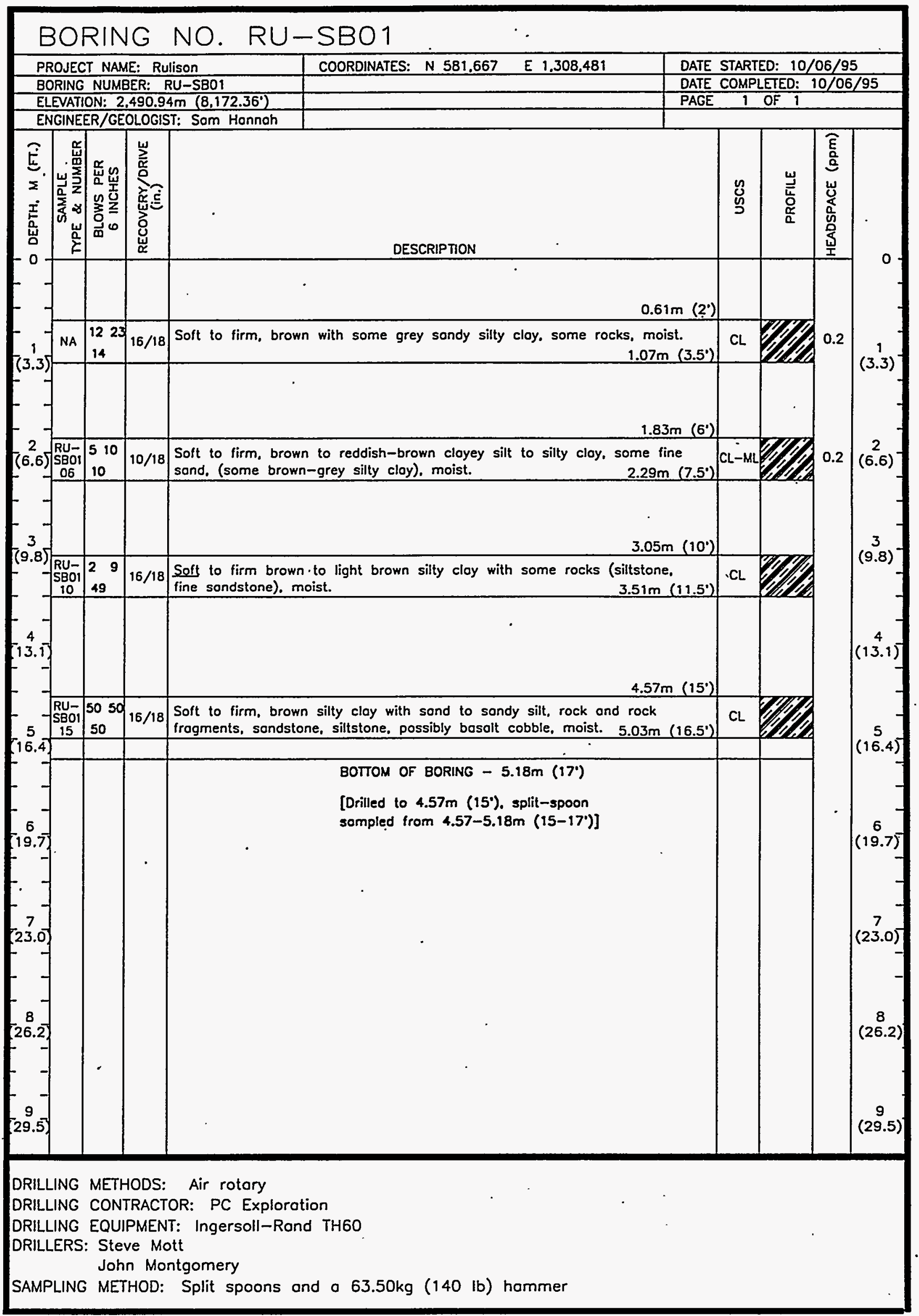




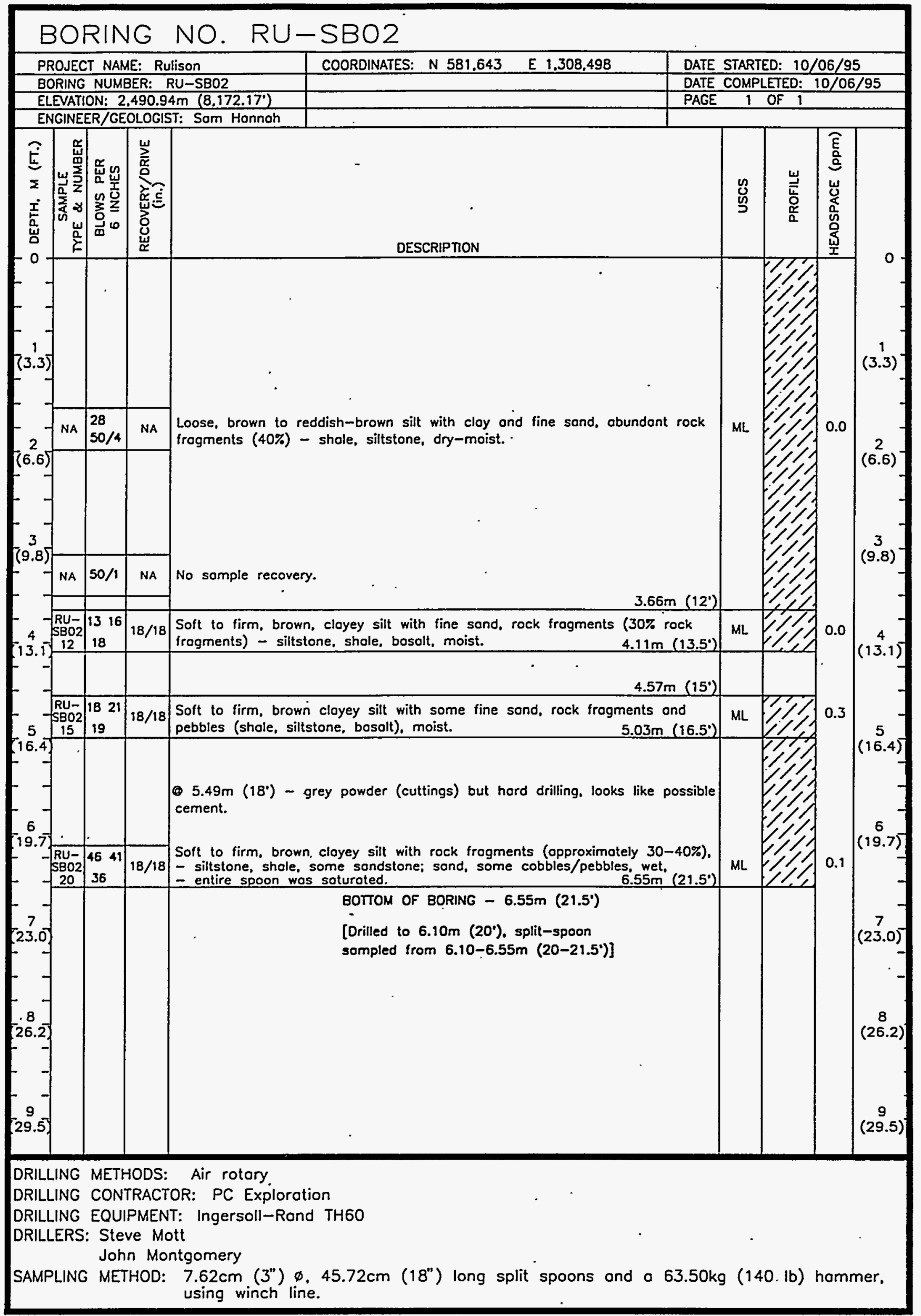





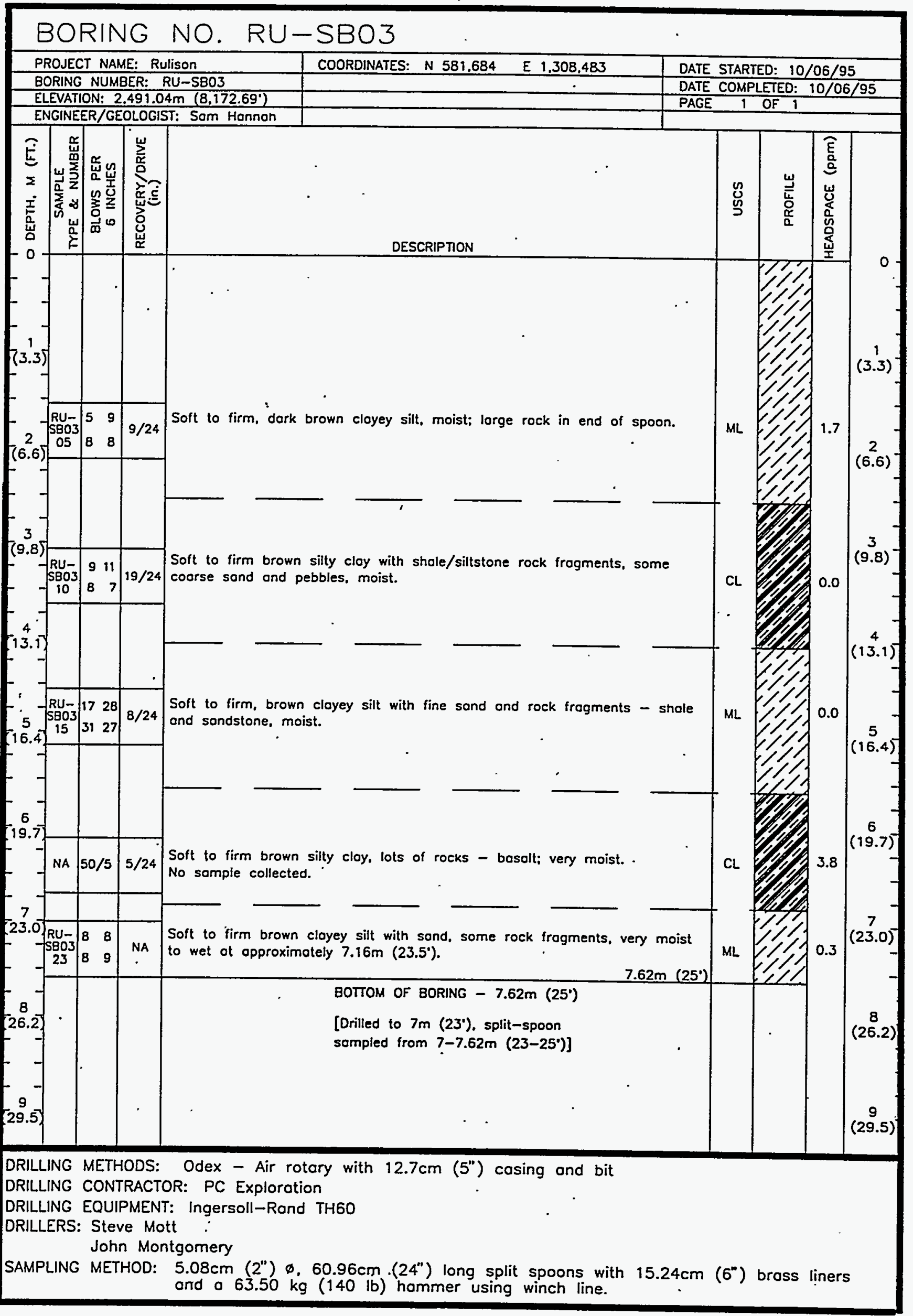





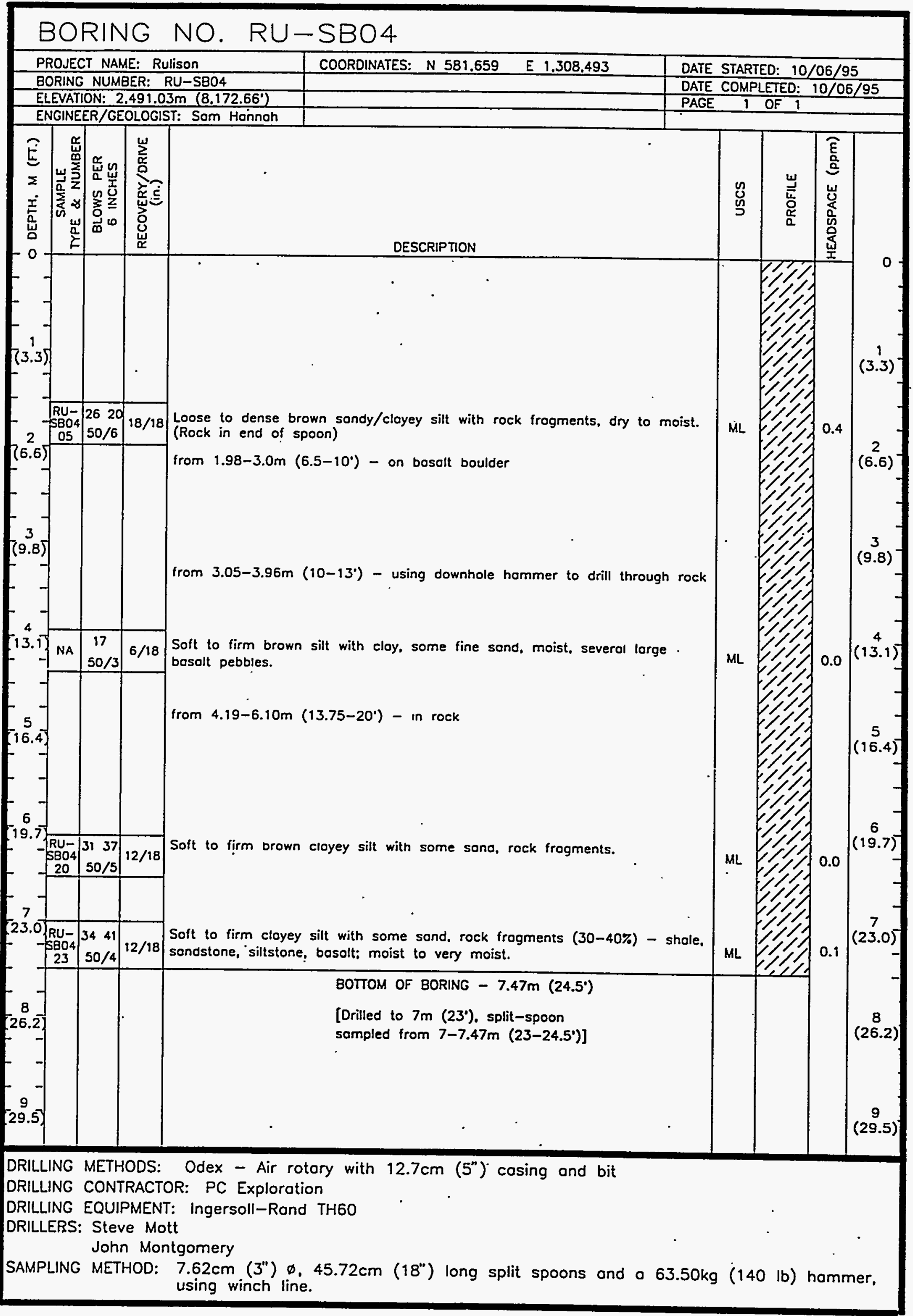



BORING NO. RU-SBO5

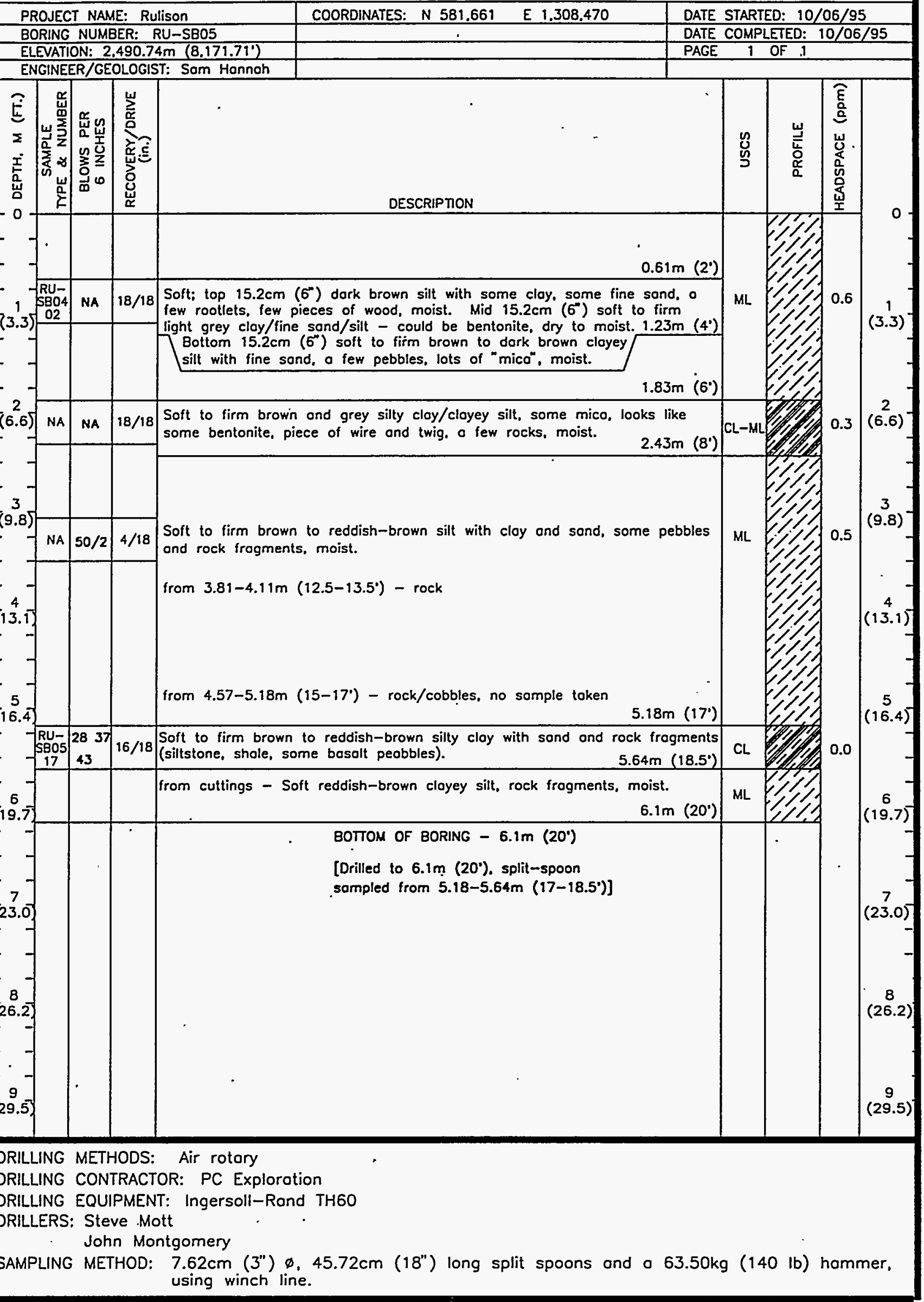



BORING NO. RU-SBO6

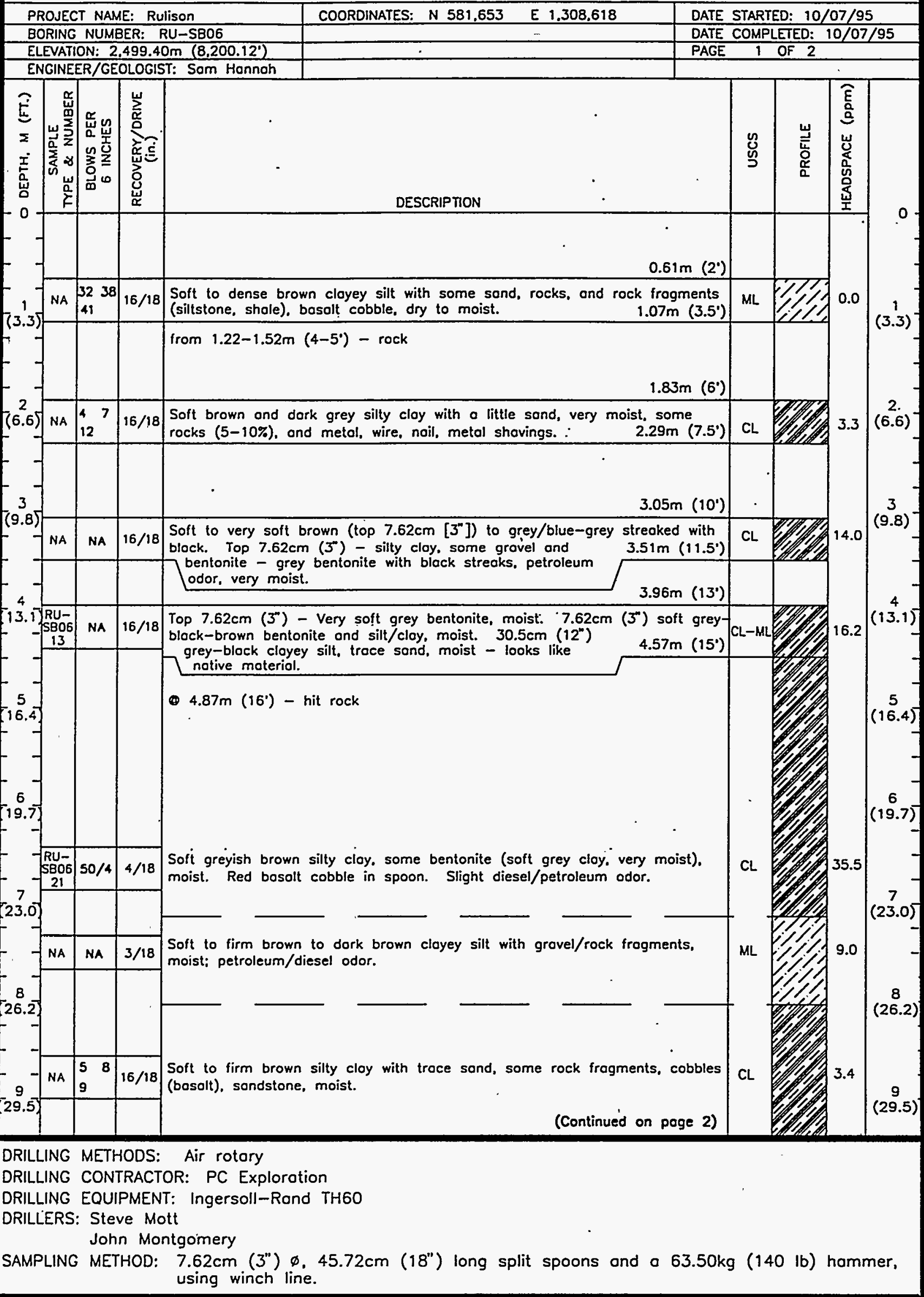




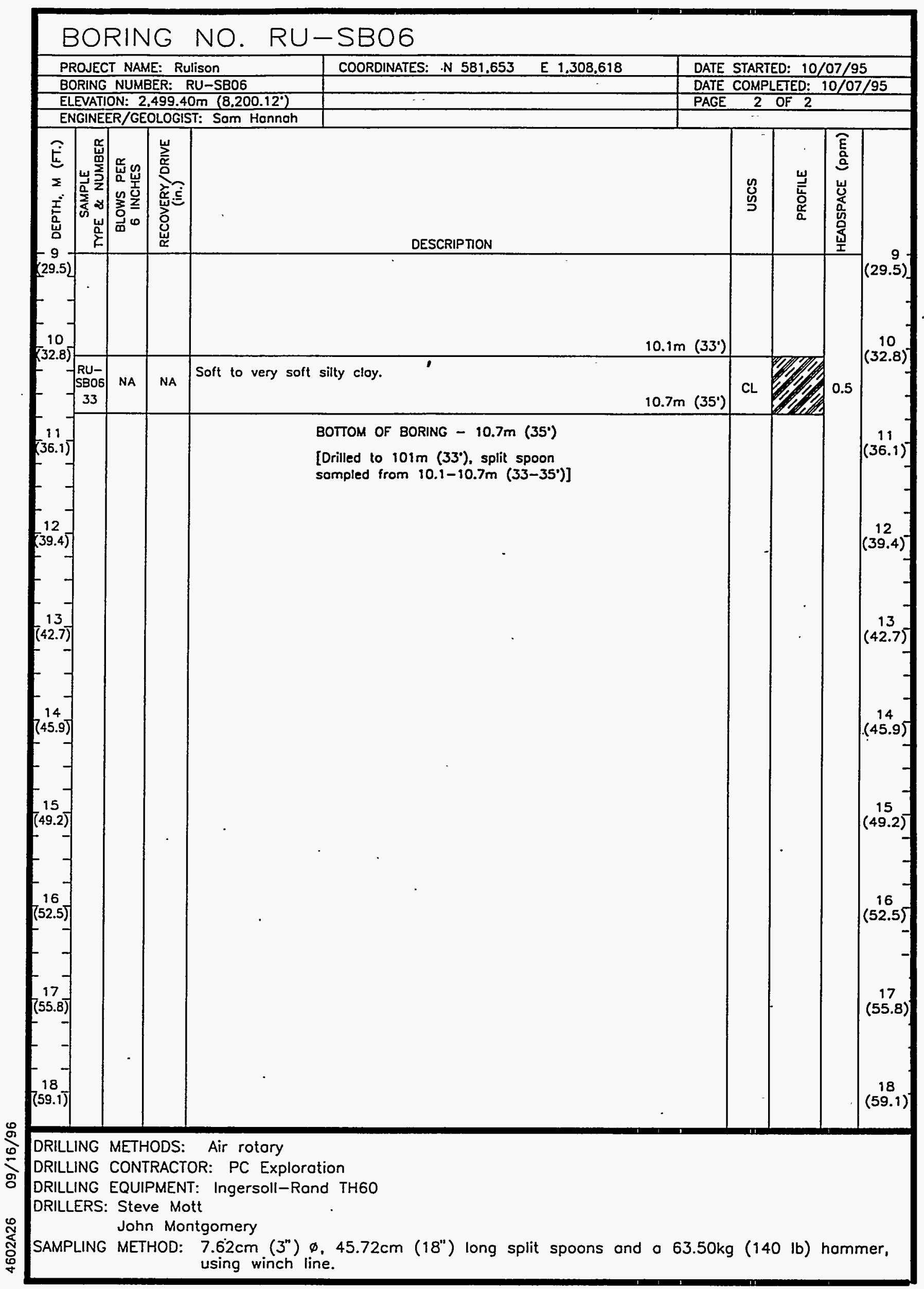




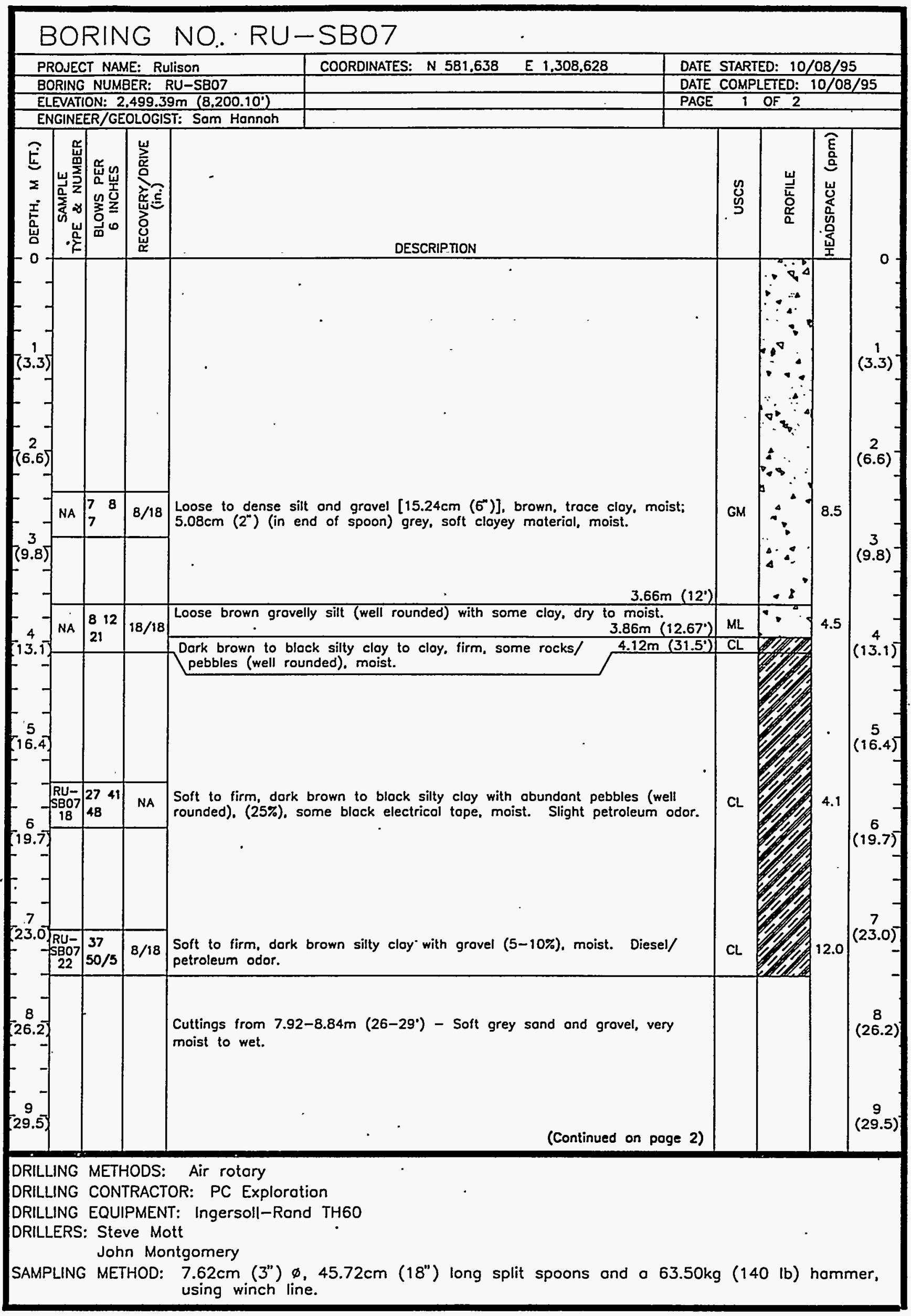




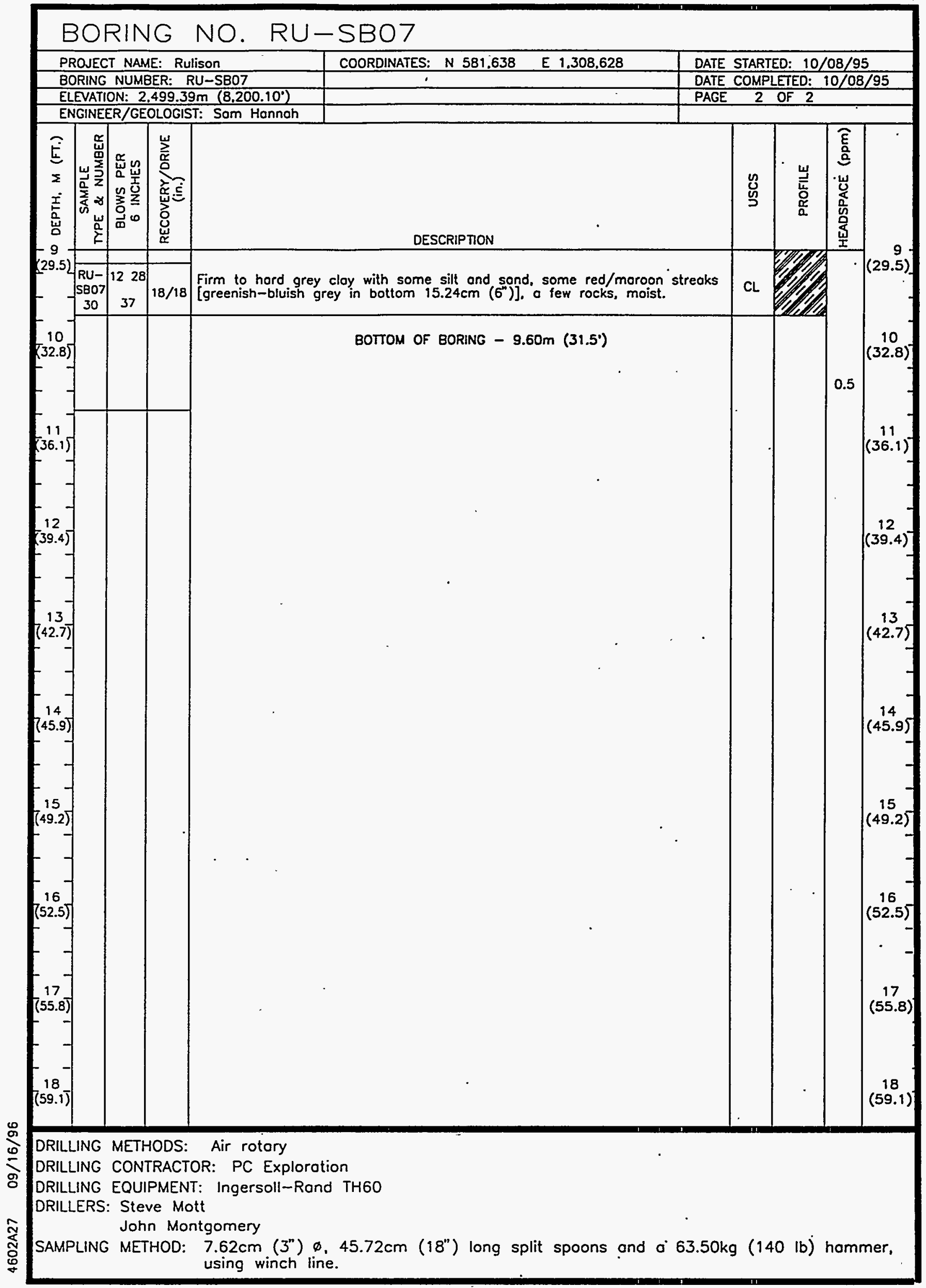


BORING NO. RU-SBO8

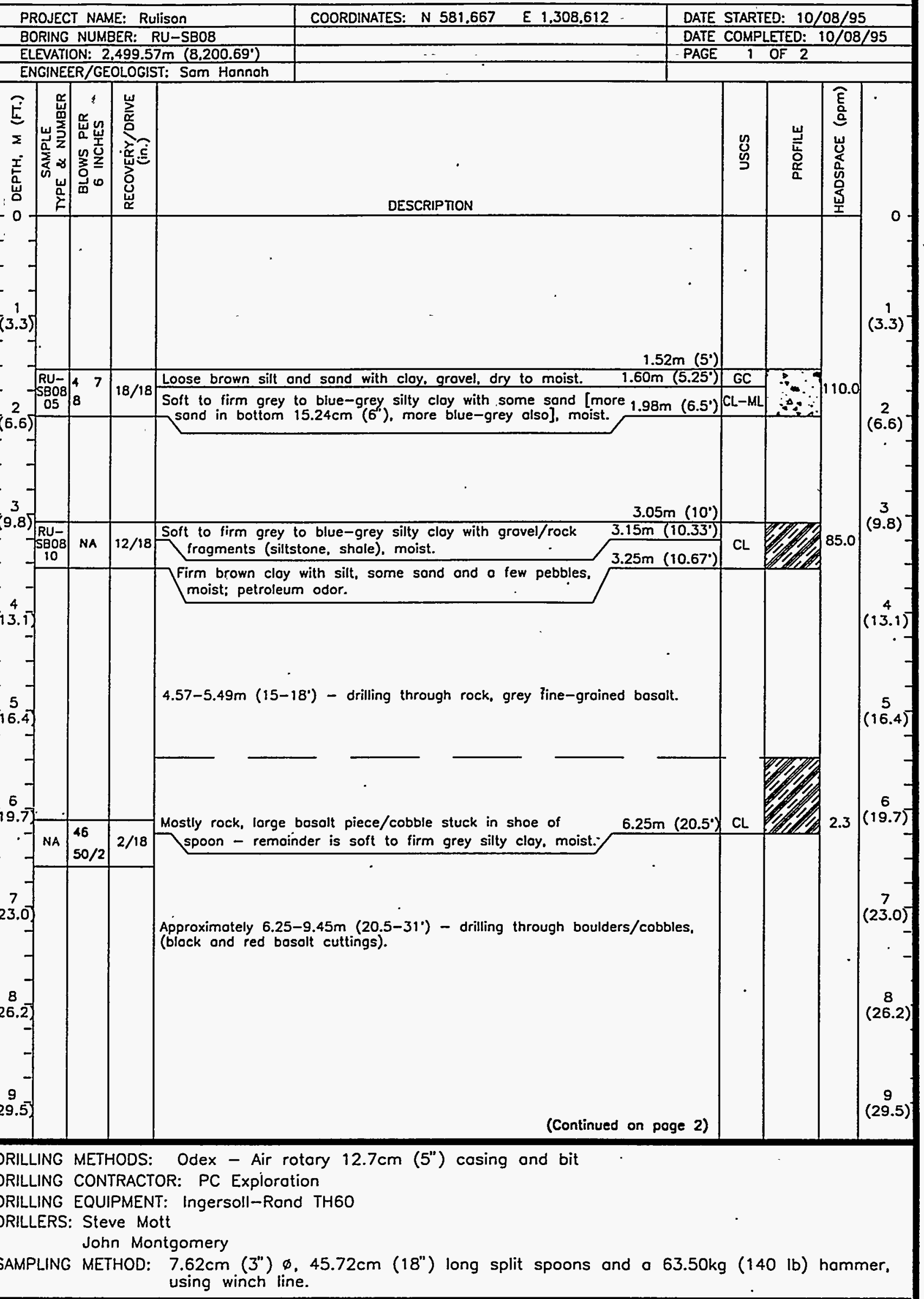




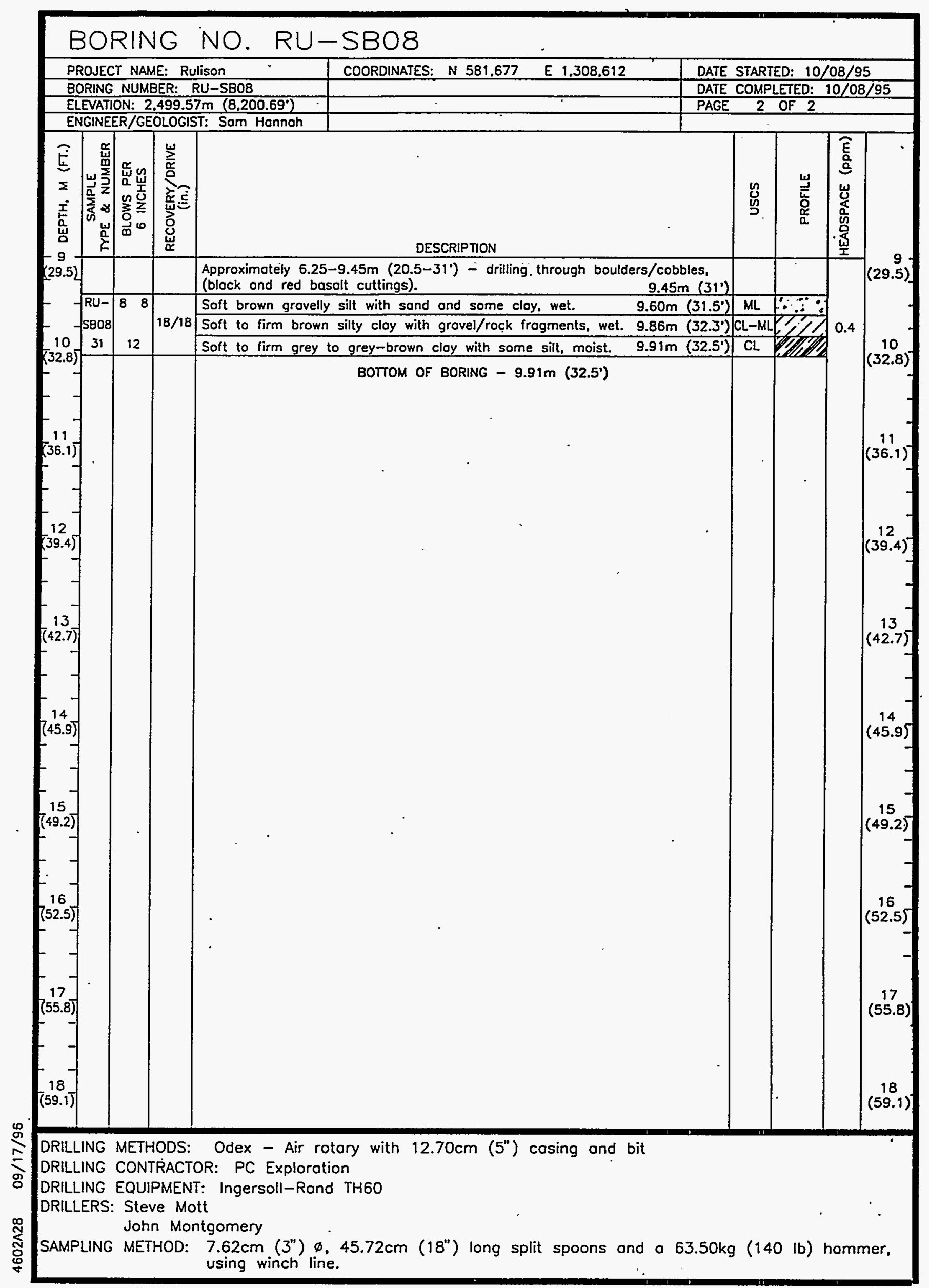


Appendix G

Monitoring Well Boring Logs and Construction Diagrams 



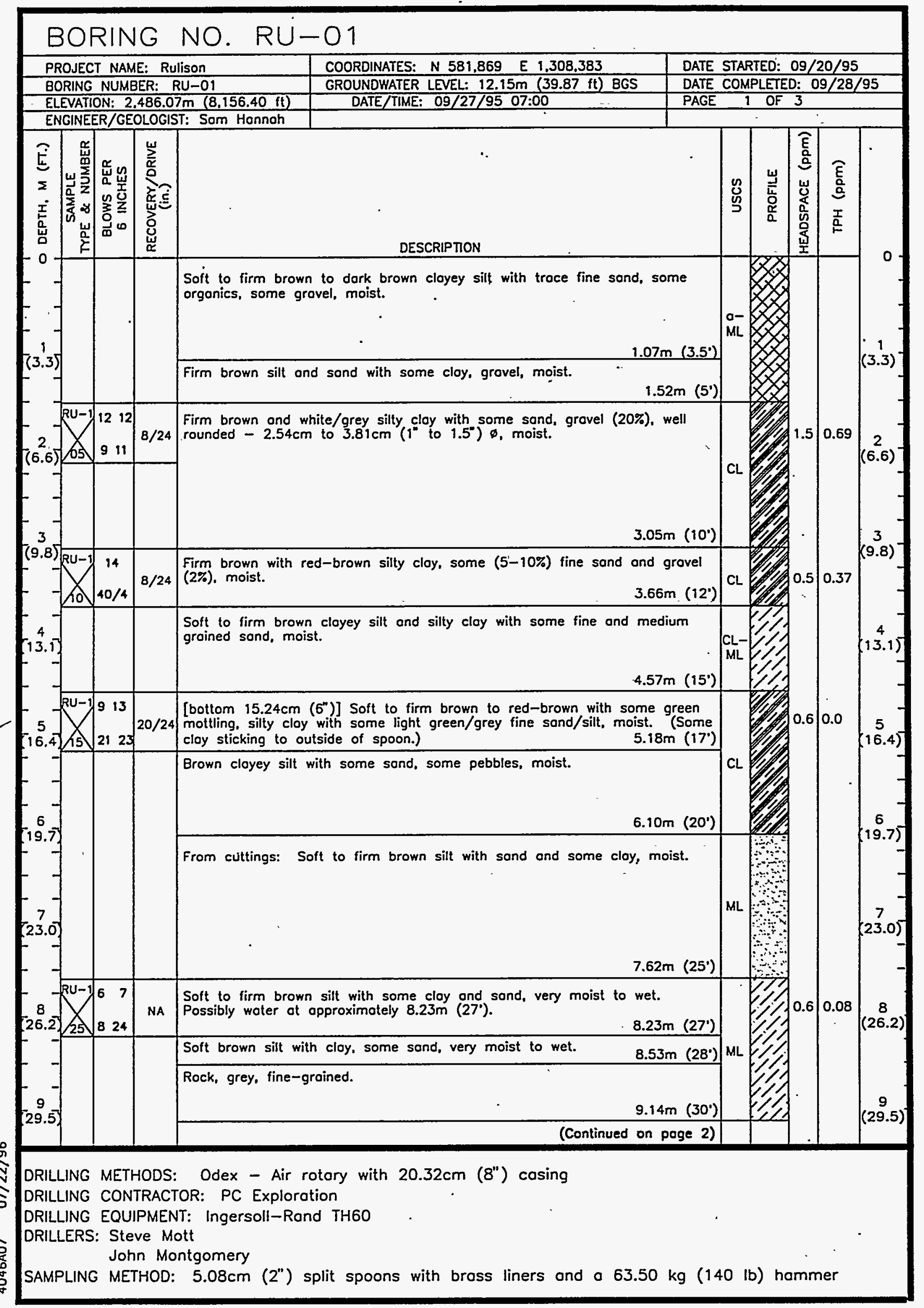




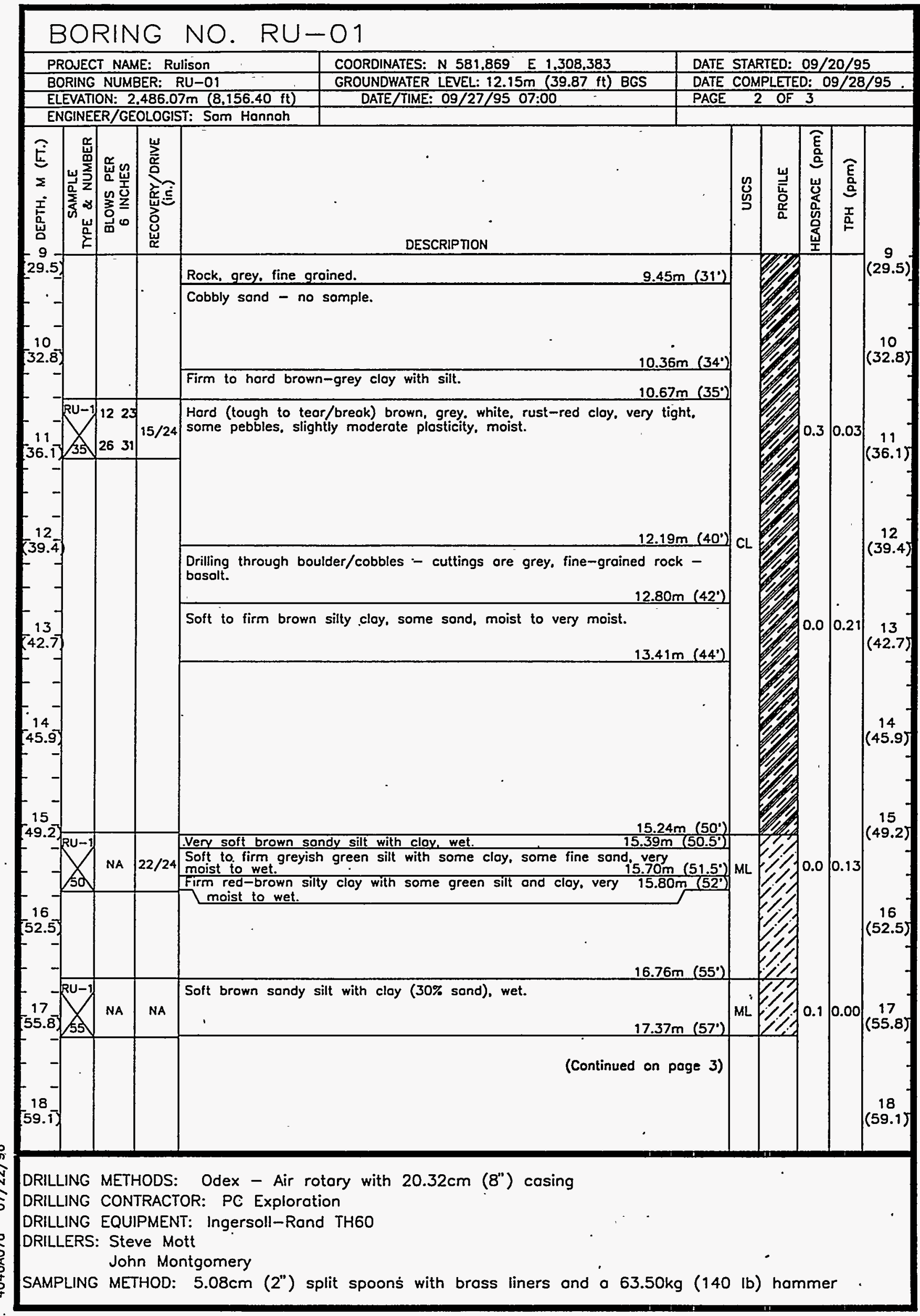

G-2 


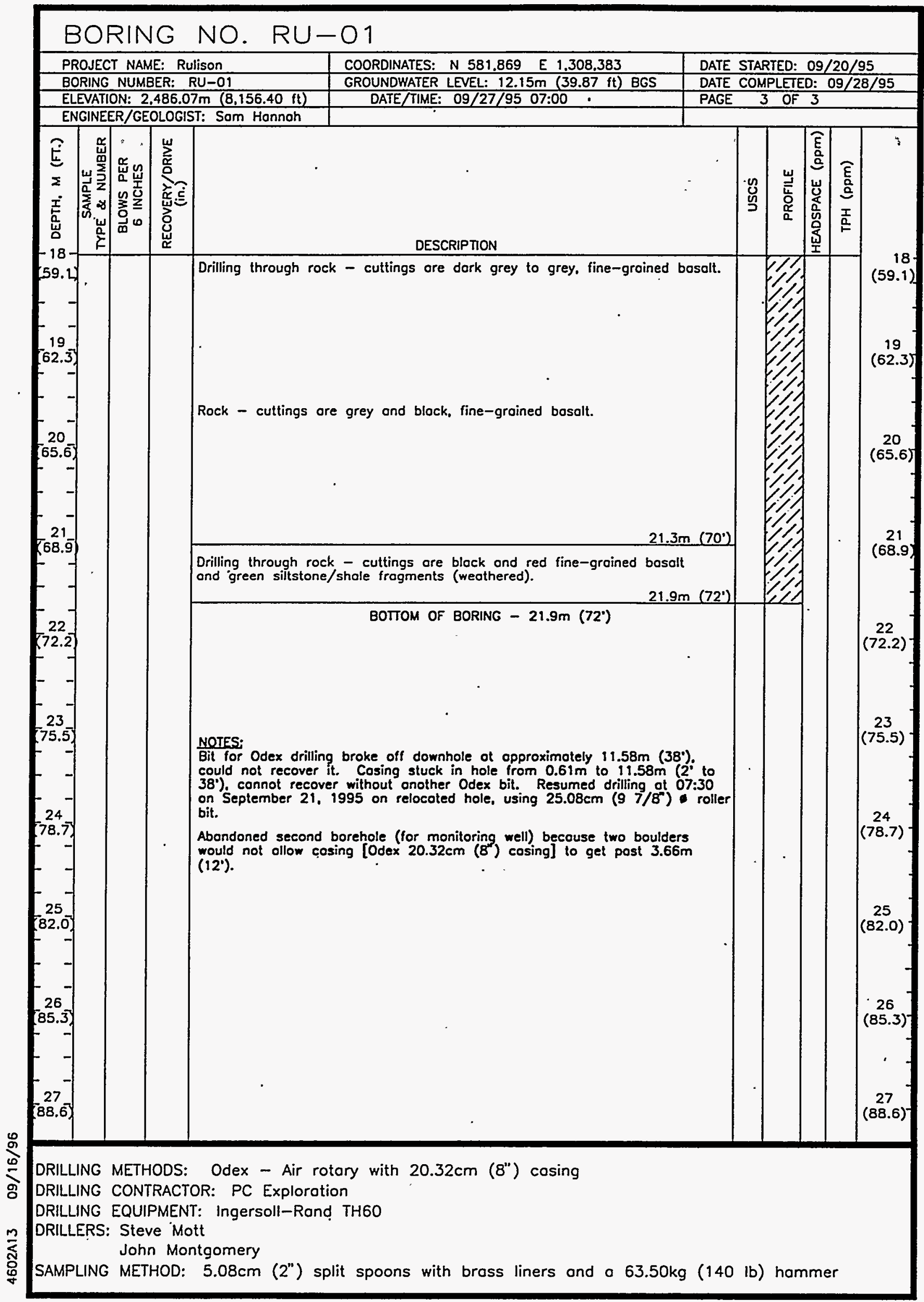




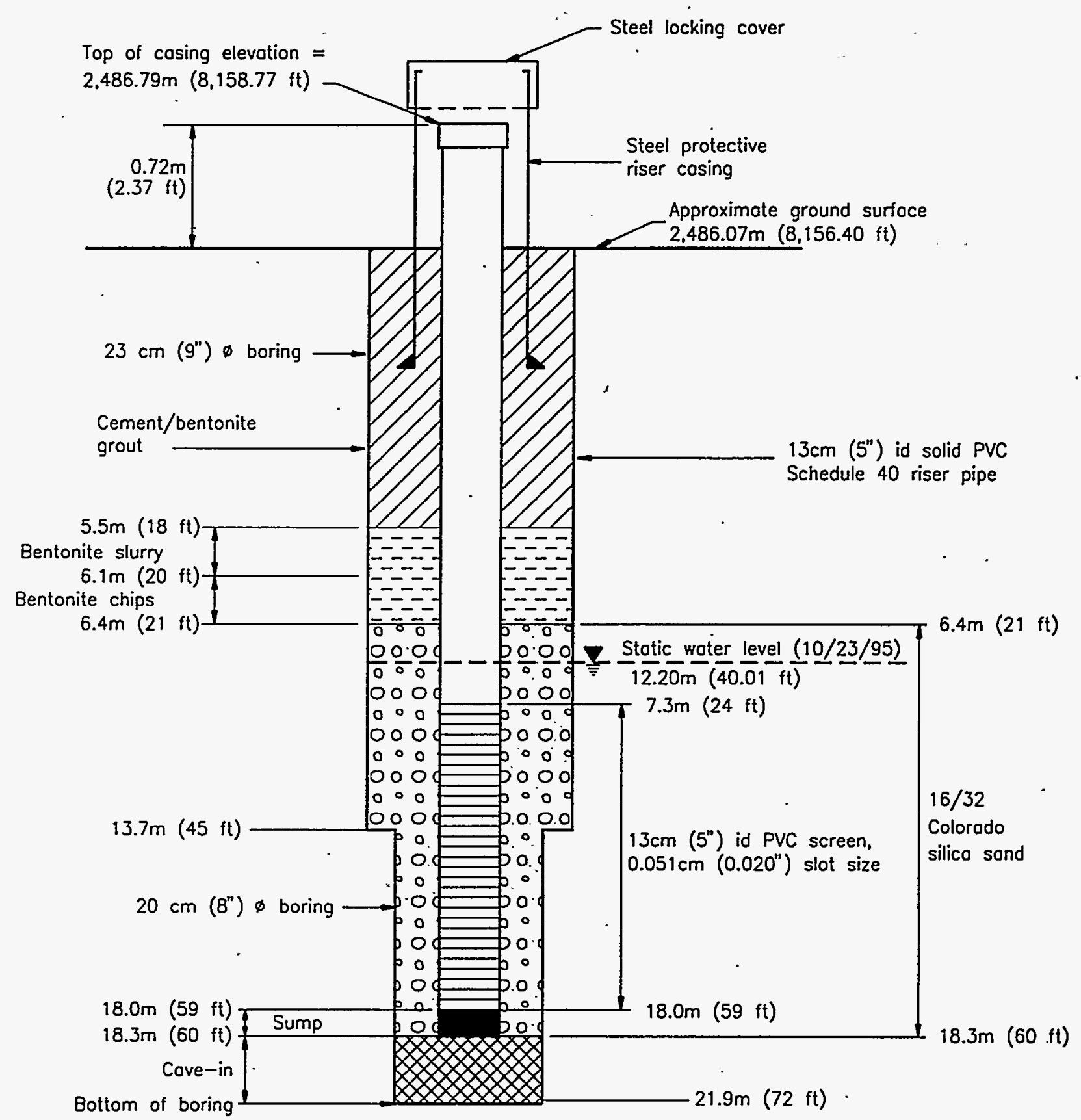

NOT TO SCALE

(All depths ore below ground surface)

Well RU-9

Installed: 09/28/95

Coordinotes: Colorodo Stote Plonor

N 581,868.9401 E 1,308,383.3567
LEGEND

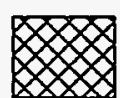

Borehole cave-in

Cement/bentonite grout

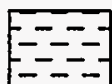

Bentonite slurry/ hydrated bentonite pellets

000 p.o.o
16/32 Colorodo silica sand

Rulison Drilling Effluent Pond-Schematic Well Construction Diagram Monitoring Well RU-1 
BORING NO. RU -02

PROJECT NAME: Rulison

COORDINATES: N 582.010 E 1.308 .392 DATE STARTED: $10 / 03 / 95$

BORING NUMBER: RU-02

ELEVATION: $2.485 .22 \mathrm{~m}(8,153.60 \mathrm{ft})$

ENGINEER/GEOLOGIST: Som Hannoh

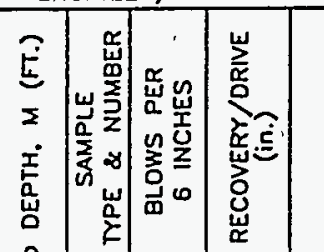

DESCRIPTION

From cuttings - soft brown to dork brown silt with fine sond, trace clay, organic motter, a few pebbles, moist.

DATE COMPLETED: $10 / 05 / 95$

PAGE

DESCRIPTION
gan cuttings - soft brown to dork brown silt with fine sond, trace clay.
ganic a few pebbles, moist.

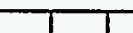

(2)

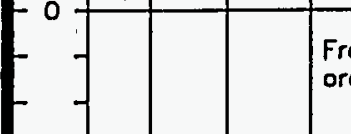

$(3.3)$

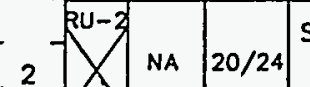

Soft to firm brown clayey silt with some sond, some pebbles, moist.

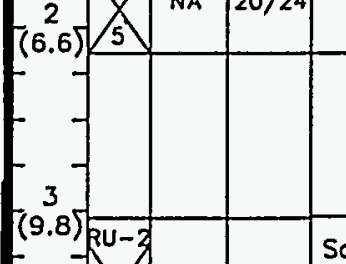

NA $16 / 24$ frogments, moist.

\begin{tabular}{|l|l|l|l|l}
\hline & & & \\
\hline & &
\end{tabular}

Brown cloyey silt with lots of shale frogments, some weothered (25-30\% shole frogments). moist.

NU NA $18 / 24$ Soft to firm brown cloyey silt with fine sond. rock frogments (shole/ 5
16.4 NA $18 / 24$ liltstone).(25-30\% rock frogments). moist.

Soft to firm brown cloyey silt with fine sond, rock frogments-predominiontly sittstone (brown), (30-35\% rock frogments), moist.

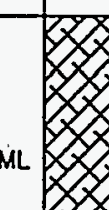

(2)

(1)

$6.71 \mathrm{~m}$

DRILLING METHODS: Odex - Air rotary, with $17.78 \mathrm{~cm}\left(7^{\prime \prime}\right)$ cosing

DRILLING CONTRACTOR: PC Explorotion

DRILLING EQUIPMENT: Ingersoll-Rand TH6O

DRILLERS: Steve Mott

SAMPLING METHOD: Split spoons and a $63.50 \mathrm{~kg}(140 \mathrm{lb})$ hammer 


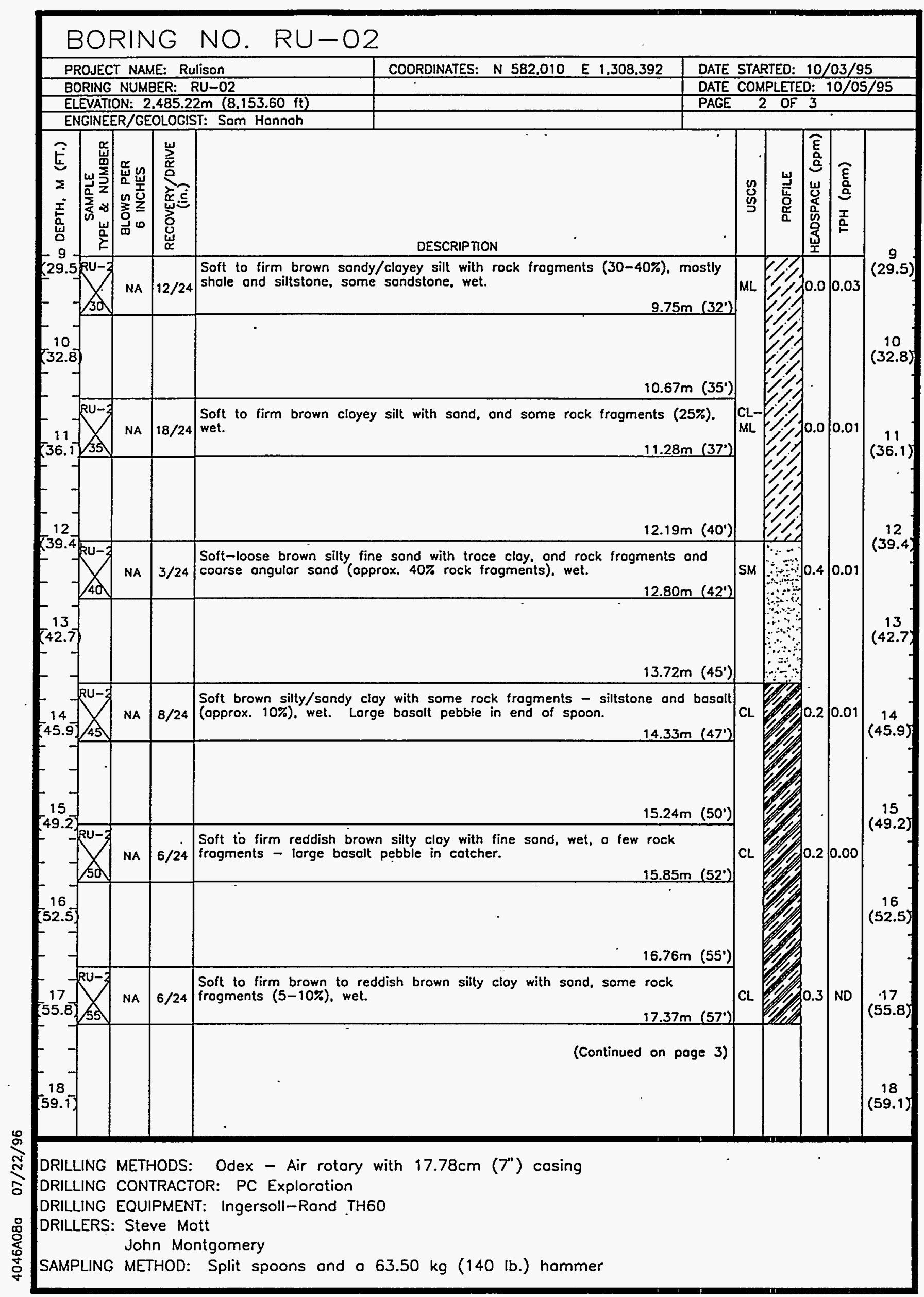




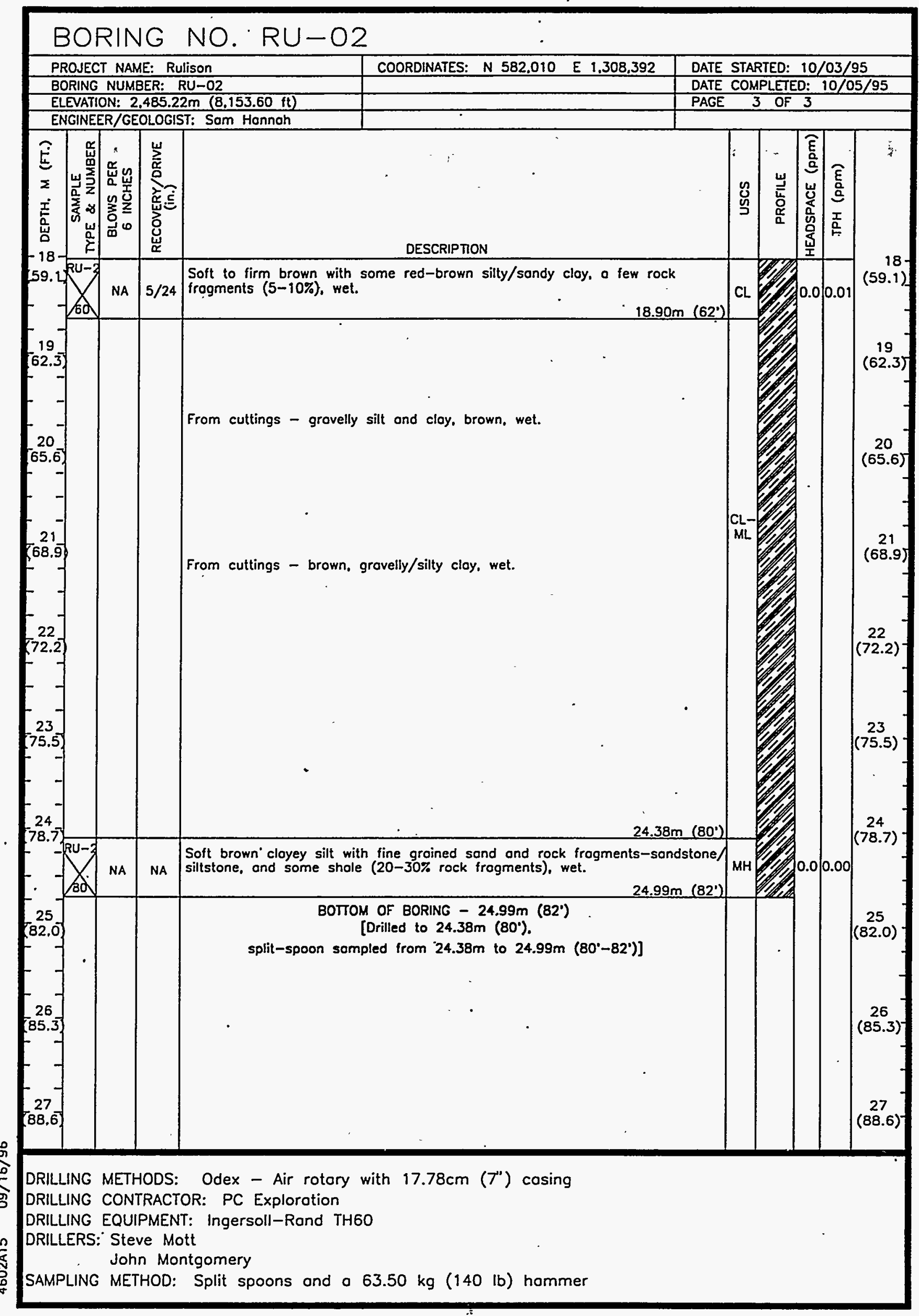




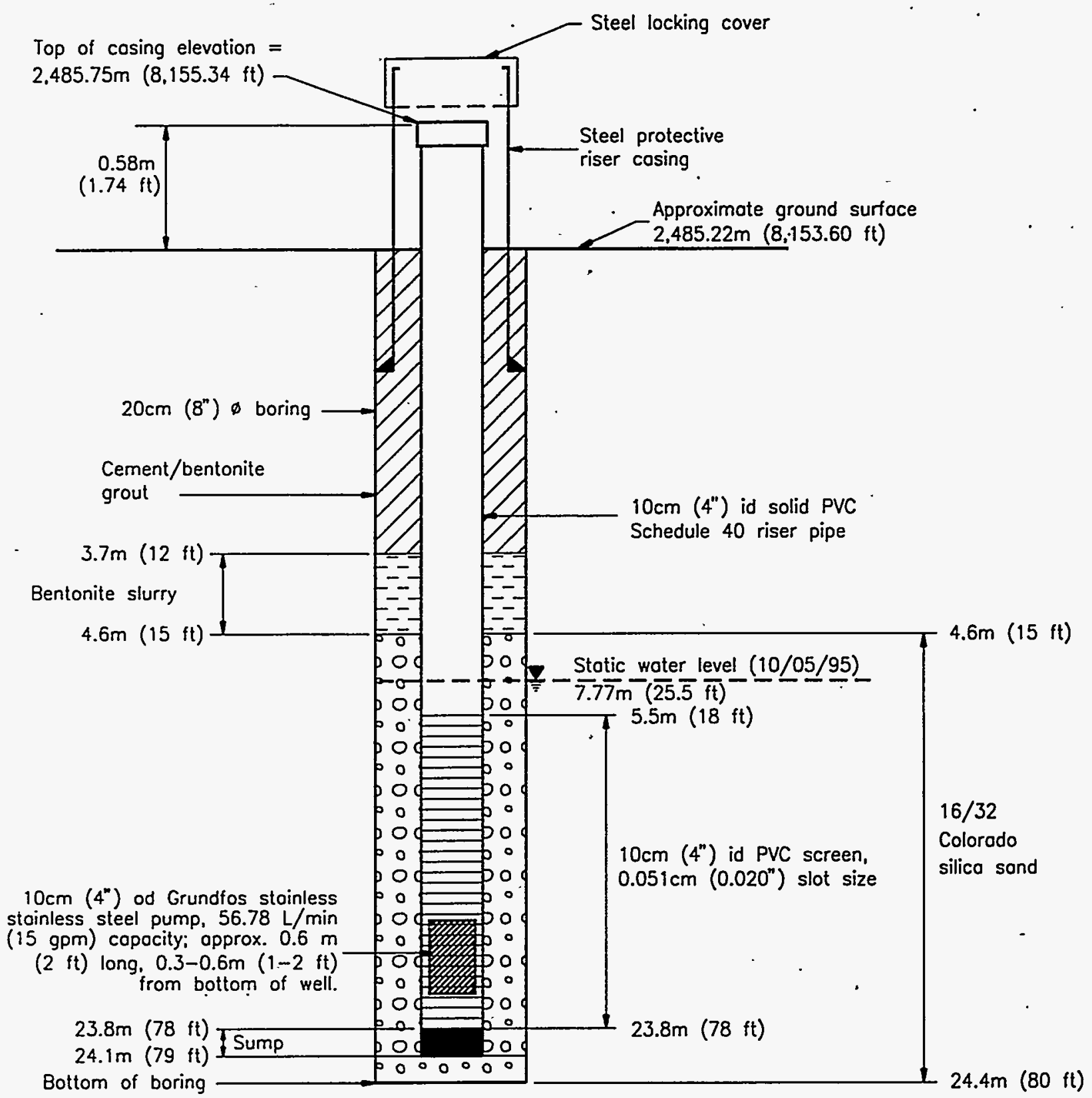

NOT TO SCALE

(All depths are below ground surface)

Well RU-2

installed: $10 / 05 / 95$

잉
Coordinotes: Colorodo Stote Planar

N 582,010.0098 E 1,308,391.6958
LEGEND
77 Cement/bentonite grout

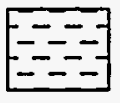

Bentonite slurry/ hydrated bentonite pellets
16/32 Colorodo

p.o. O. silico sand 


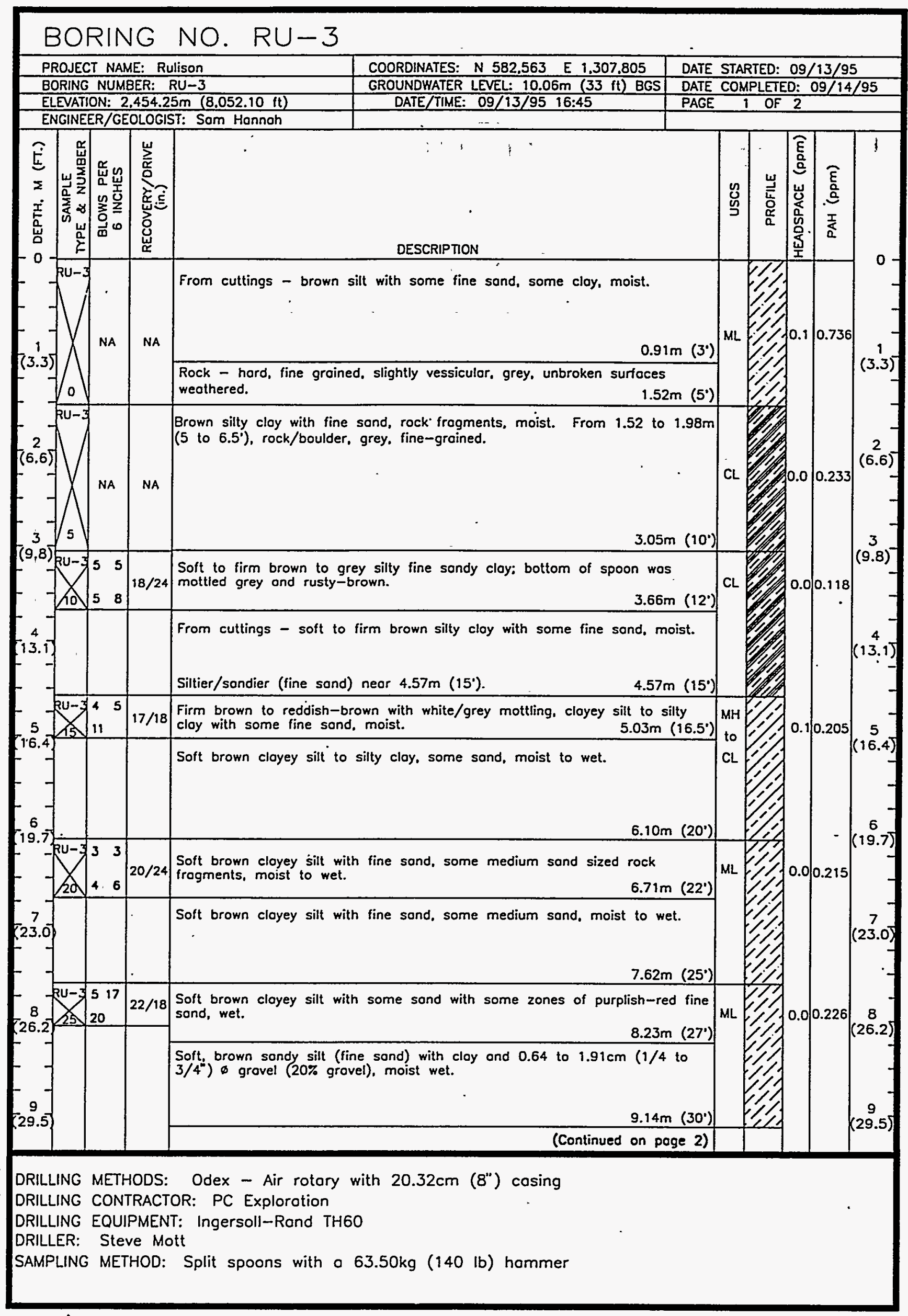




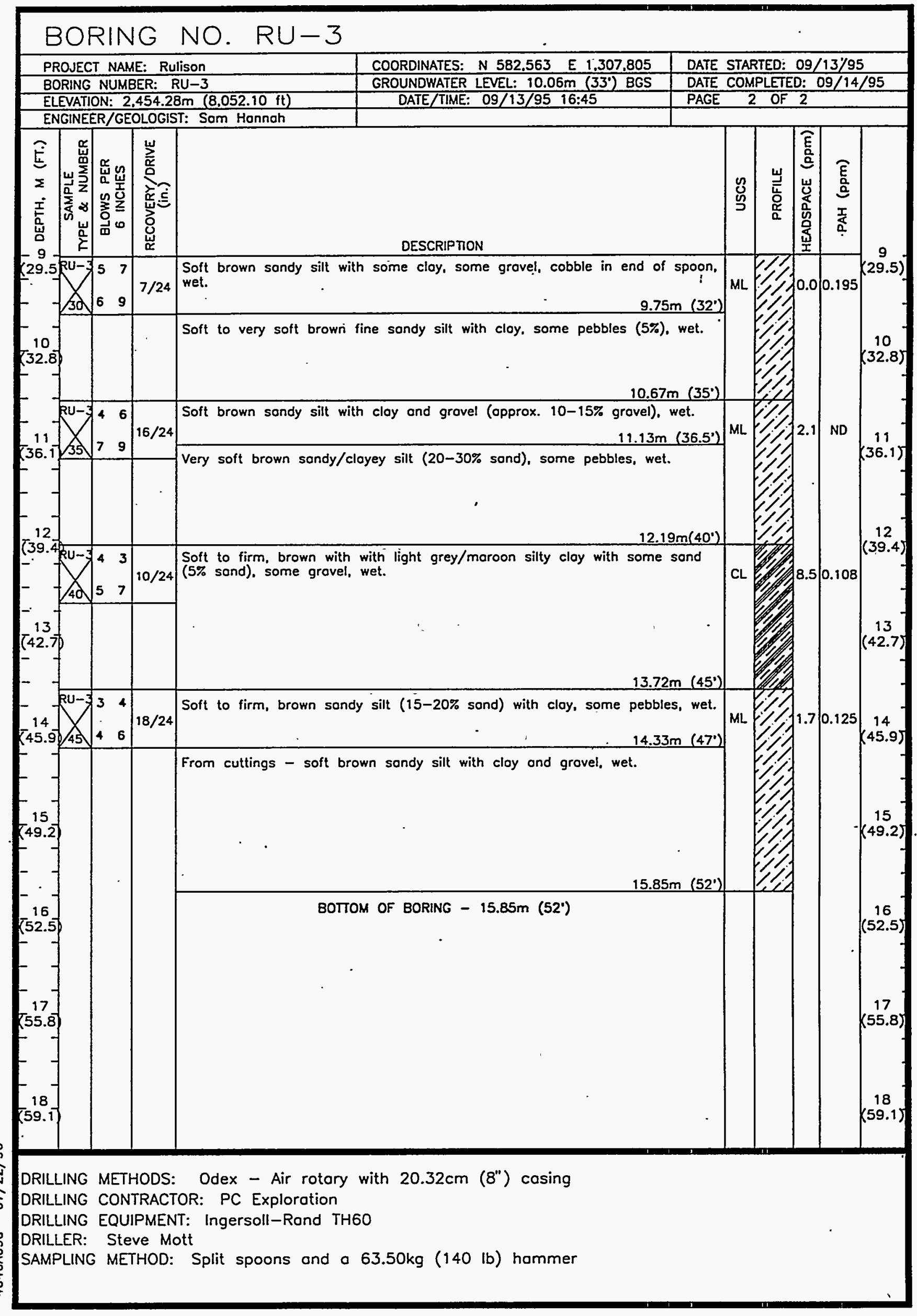




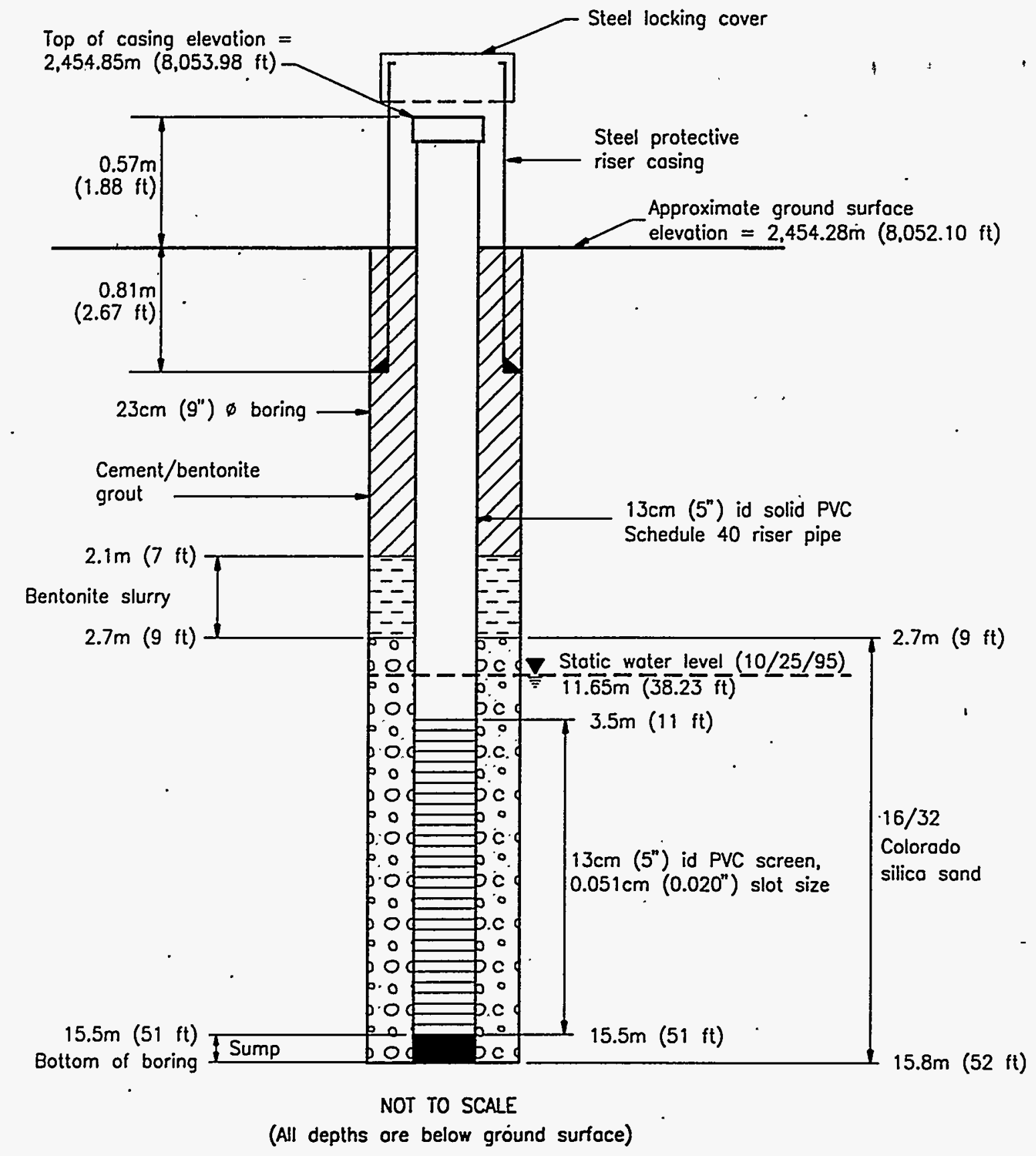

Well RU-3

installed: 09/14/95

Coordinates: Colorado Stote Planor

N 582563.2770 E $\{307804.6005$

LEGEND

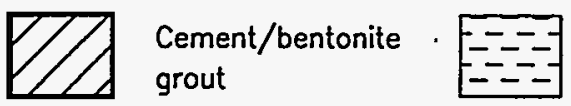

Bentonite slurry/ hydrated bentonite pellets

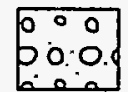

16/32 Colorado silico sand

Rulison Drilling Effluent Pond-Schematic Well Construction Diagram Monitoring Well RU-3 



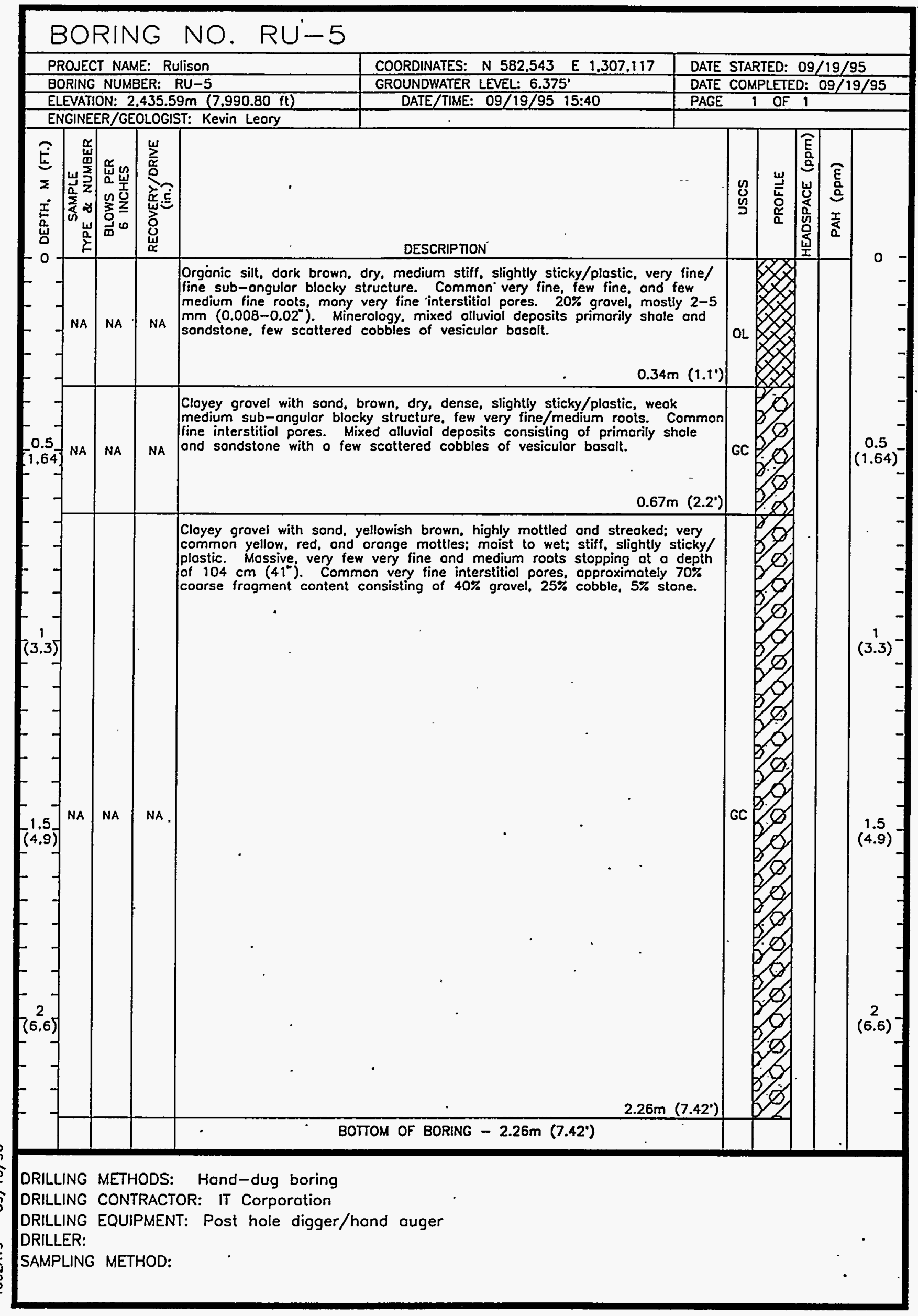




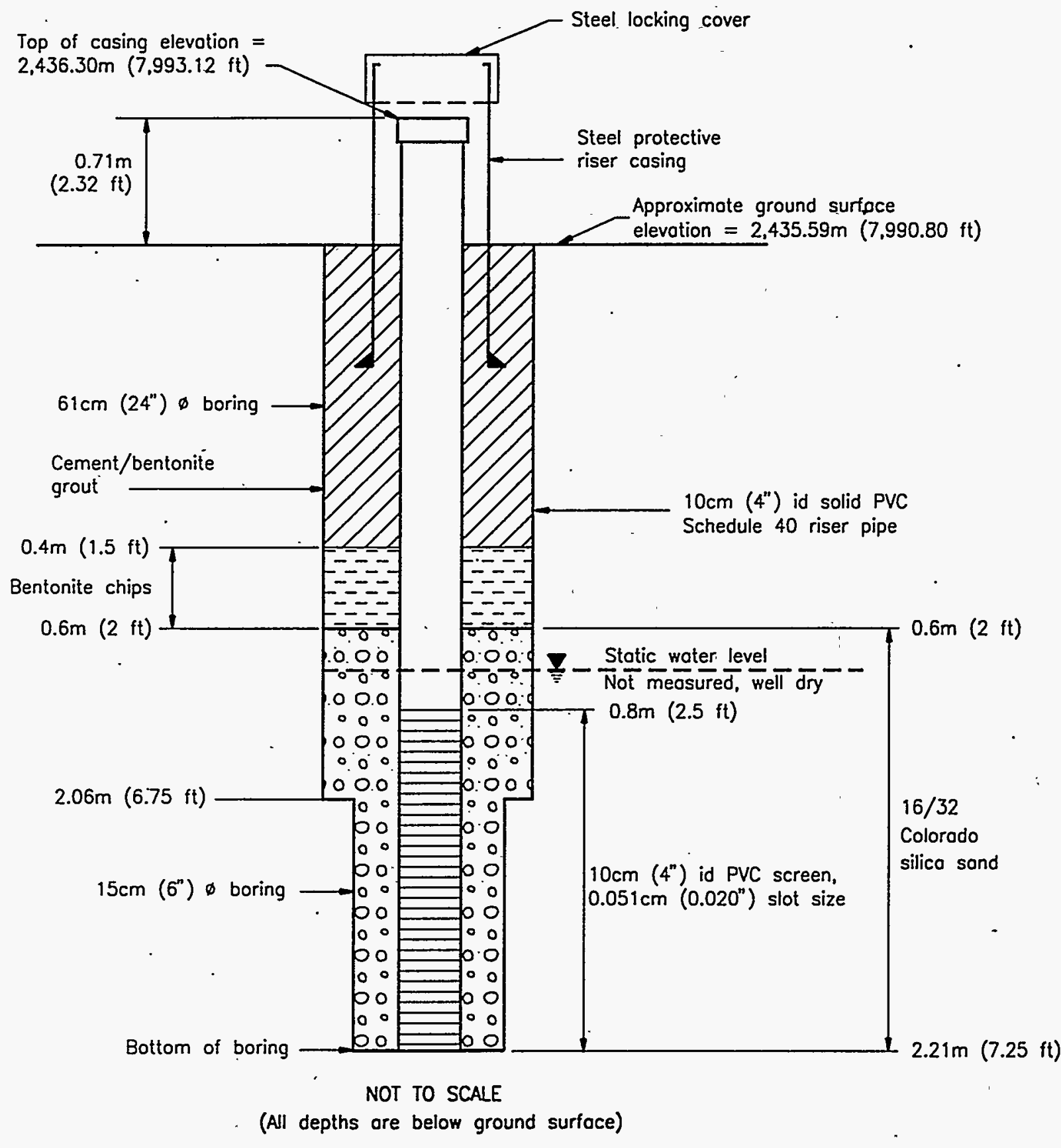

Well RU-5

Instolled: 09/26/95

Coordinates: Colorado State Planar

N 582543.2696 E 1307116.7871
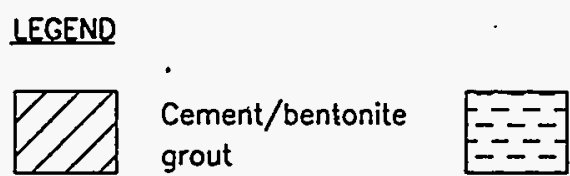

Hydrated bentonite chips 
BORING NO. RU -6

\begin{tabular}{|l|l|l|l} 
PROJECT NAME: Rulison & COORDINATES: N 582.719 & DATE STARTED: 09/28/95
\end{tabular}

\begin{tabular}{l|c|c} 
BORING NUMBER: RU-6 (Abondoned) & E 1.307.194 & DATE COMPLETED: 09/28/95
\end{tabular}

ELEVATION: TOP of PVC $=2.432 .46 \mathrm{~m}(7.980 .50 \mathrm{ft})$

ENGINEER/GEOLOGIST: Kevin Leary

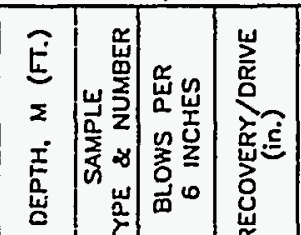

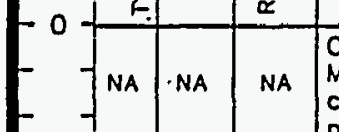

OESCRIPTION

Organic silt, dark brown, dry, medium stiff, slightly sticky and slightly plastic.

colluvial origin: sub-angular blocky structure. Mixed minerology of

pores: common very fine, few fine, medium, ond coorse roots.

$-1 \quad 10 \%$ grovel, mostly $2-5 \mathrm{~mm}\left(0.008-0.02^{\circ}\right)$ o ronge.

Inorgonic clay, dork brown, dry. stiff, sticky and plostic; weok-coorse ond

very coorse sub-ongular blocky structure; mixed minerology of colluvial

origin; common very fine and fine interstitial pores; few, fine, tubulor pores:

few very fine and fine roots; $20 \%$ gravel, mostly $2-5 \mathrm{~mm}\left(0.008-0.02^{\prime}\right)$ ronge.

$0.43 m\left(1.4^{\prime}\right)$

Orgonic silt, very dark brown, slightly moist, sligntly sticky and slightly plostic: moderote. medium sub-ongular blocky structure: mixed minerology of colluvial origin: mony very tine ond fine interstitiol pores; very few, very fine, and fine roots.

$\left[\begin{array}{c}0.5 \\ 1.64]\end{array} \quad\right.$

DRILLING METHODS: Hand-dug boring

DRILLING CONTRACTOR: IT Corporation

DRILLING EQUIPMENT: Post hole digger/hand ouger

$1.10 \mathrm{~m}\left(3.6^{\circ}\right)$

Water bearing zone (dry): clayey sand with grovel, light brown, moist, slightly sticky and slightly plastic; mossive; mixed minerology of colluvial origin; reddish and orange motties, common: common very fine interstitial pores: few very fine and fine roots; $50 \%$ gravel, $10 \%$ cobble. $1.30 \mathrm{~m}\left(4.25^{\prime}\right)$

BOTTOM OF BORING - $1.30 \mathrm{~m}\left(4.25^{\prime}\right)$ 



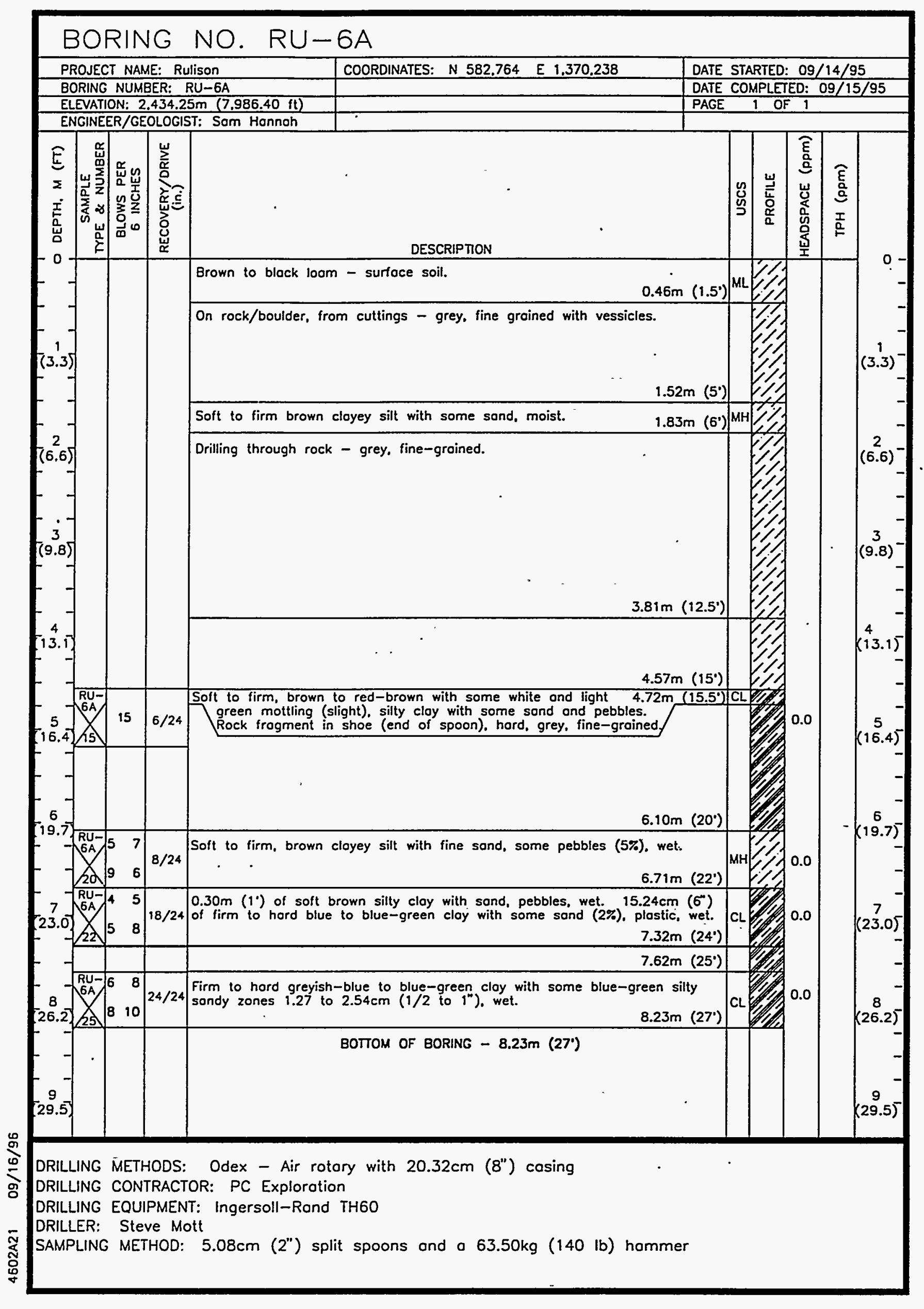




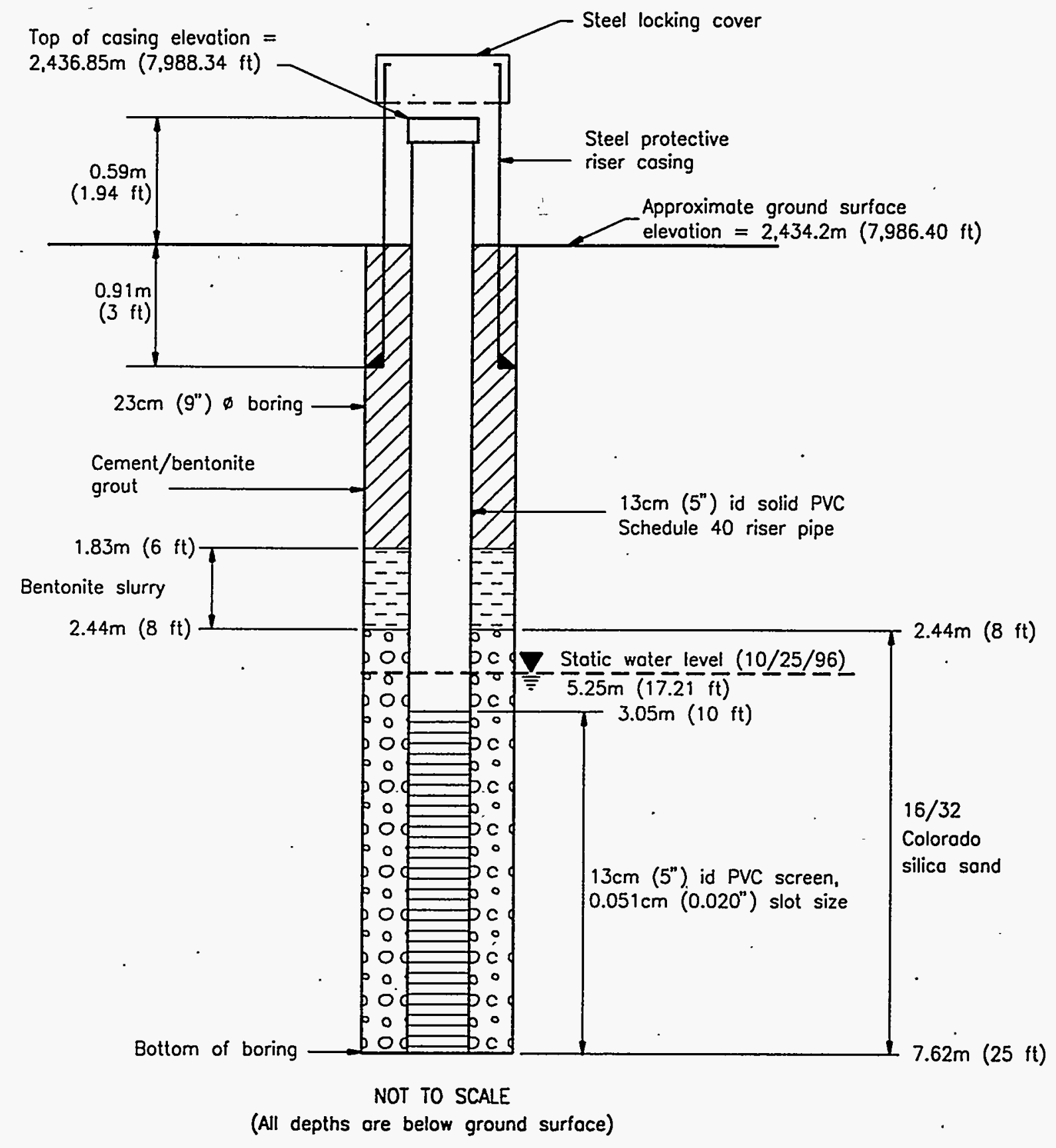

Well RU-6A

Installed: $09 / 15 / 95$

Coordinates: Colorodo State Planar

N 582,764.2546 E 1,307,237.8146

LEGEND

17 Cement/bentonite grout
Eentonite slurry

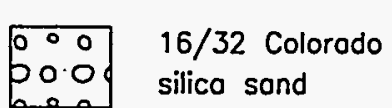

Rulison Drilling Effluent Pond-Schematic Well Construction Diagram Monitoring Well RU-6A 


\section{BORING NO. RU -7}

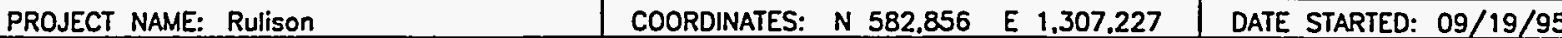

\begin{tabular}{|c|c|c|}
\hline BORING NUMBER: $\quad$ RU 7 & 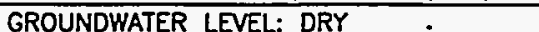 & DATE COMPLETED: $09 / 19 / 95$ \\
\hline
\end{tabular}

ENGINEER/GEOLOGIST: Kevin Leary

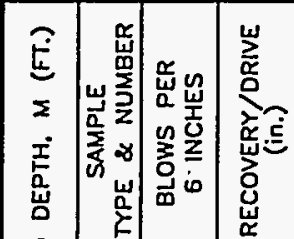

DESCRIPTION

Organic silt, dork brown, dry, medium stiff, slightly sticky/plostic; very fine/

fine sub-angular blocky structure; common very fine, few fine, and few

medium roots, many very fine interstitial pores; $25 \%$ gravel, all $2-5 \mathrm{~mm}$

$\left(0.008-0.02^{\prime \prime}\right) \varnothing$. Minerology mixed alluviol deposits, primorily sandstone NA NA NA $\begin{aligned} & (0.008-0.02 \\ & \text { and shale. }\end{aligned}$

\section{$0.38 m\left(1.25^{\prime}\right)$}

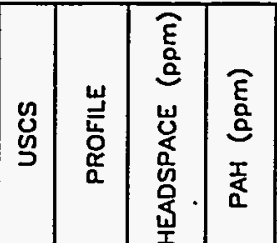

Organic silts, dork brown, dry, medium stiff, slightly sticky/plostic, medium sub-angular blocky structure, few fine common medium and few coorse roots, many very fine interstitiol pores, $20 \%$ coorse frogments, mostly 2-5 $\mathrm{mm}\left(0.008-0.02^{\prime \prime}\right)$ ø. Minerology some os above.

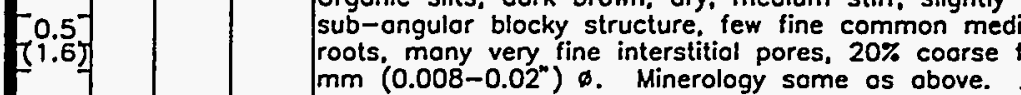

ڤั

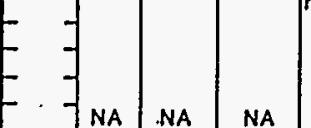

INA NA NA

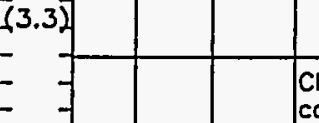

$1.14 \mathrm{~m}\left(3.75^{\prime}\right)$

OL

Clayey grovel with sand, yellowish-brown, highly mottled and streaked, very massive red, yellow, and oronge mottles; moist, stin, slightly iticky, very approximately $60 \%$ coorse frogments consisting of $40 \%$ grovel, $10 \%$ cobble, and $10 \%$ stone. 


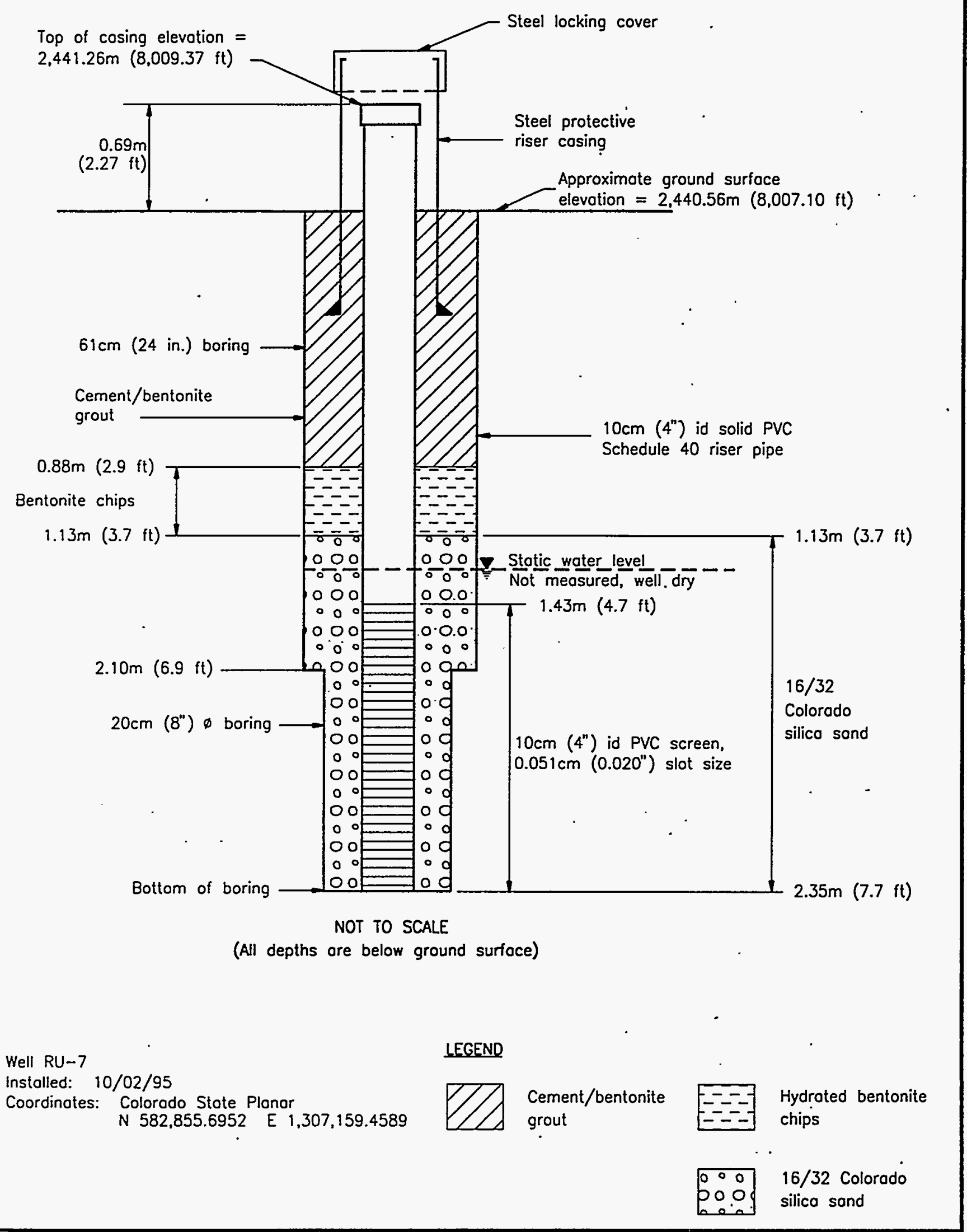

Rulison Drilling Effluent Pond-Schematic Well Construction Diagram Monitoring Well RU-7 


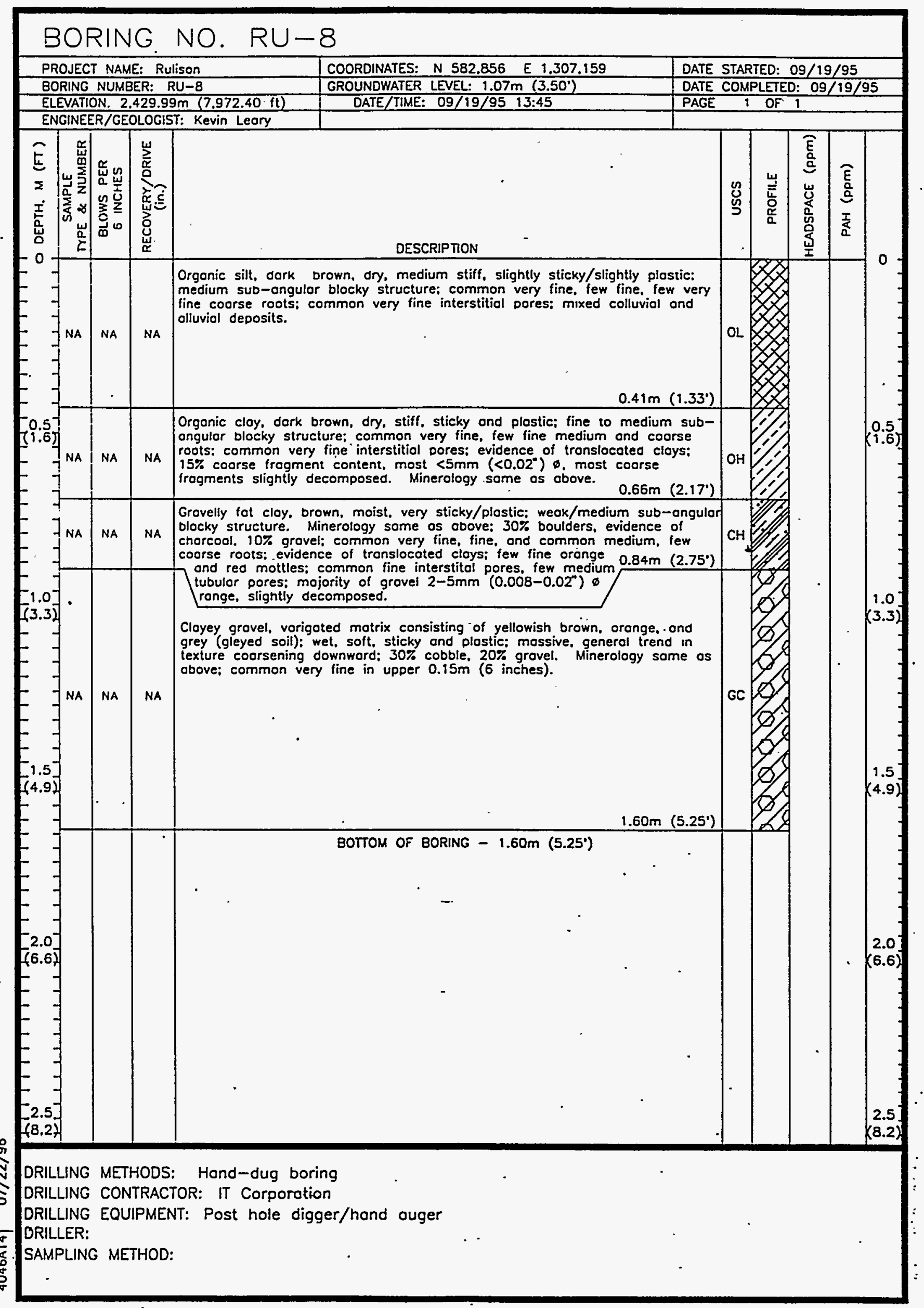




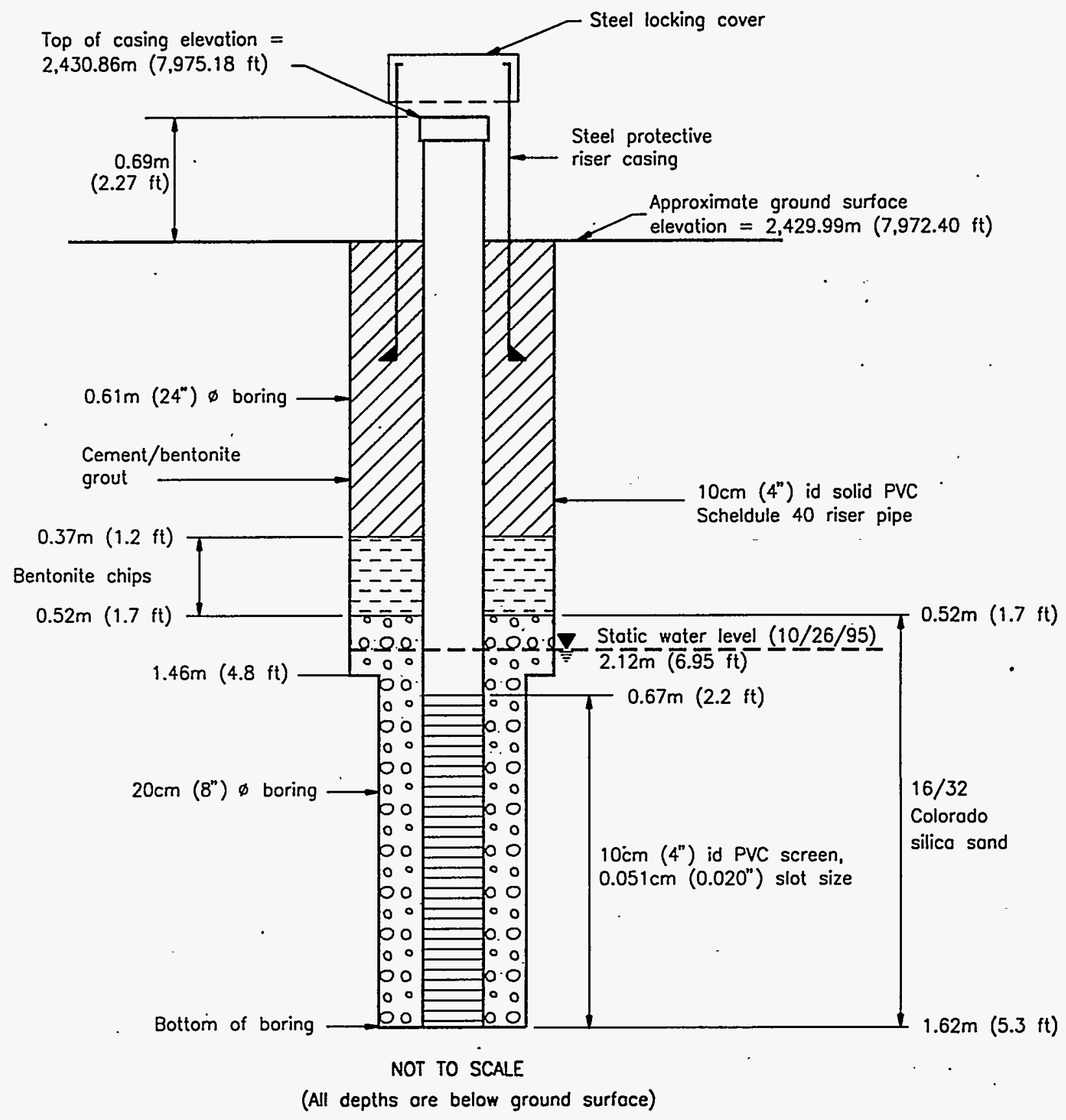

Well RU-8

Installed: 09/26/95

Coordinates: Colorado State Planar

N 582,855.6952 E 1,307.159.4589
LEGEND
7 Cement/bentonite grout

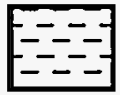

Hydrated bentonite chips 


\section{Appendix H}

Aquifer Test Data 


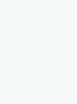




\section{Aquifer Test Data}

To estimate the hydrologic properties of the unconsolidated material present at the Rulison site, two slugs tests and one eight-hour pumping test, with recovery, were performed. Analysis of the field data was conducted using AQTESOLV (Aquifer Test Solver), a software program written by Geraghty \& Miller, Inc. (Revision 1, 1991).

To analyze the pumping test and recovery data, a Theis solution was calculated which assumed unconfined conditions, without a delayed yield from storage. The pumping rate was approximately 2 gallons per minute (gpm). These assumptions appeared to be valid because total drawdown in the pumping well was approximately 0.4 meters ( 1.3 feet), which had approximately 3 meters (10 feet) of saturated aquifer screened. A piezometer, located approximately 8 feet from the pumping well, had approximately 3 centimeters $(0.1 \mathrm{feet})$ of drawdown during the test. Accurate aquifer parameters could not be calculated using the piezometer data. Hydraulic conductivities calculated from the pumping well pumping and recovery data were $5 \times 10^{-3}$ centimeters per second $(\mathrm{cm} / \mathrm{sec})$, respectively.

Slug tests were performed on Wells RU-3 and RU-6. The rise in head in each test was approximately 1 foot while the saturated thickness of the aquifer screened was approximately 13 feet in Well RU-3 and 8 feet in Well RU-6. An unconfined aquifer was assumed and a Bouwer-Rice solution calculated. The hydraulic conductivity for Well RU-6 was calculated to be $8 \times 10^{-4} \mathrm{~cm} / \mathrm{sec}$. A hydraulic conductivity for the RU-3 slug test could not be accurately calculated because the aquifer responded too quickly and in a nonlinear manner. This indicates that there was either not an adequate rise in head during the test or the hydraulic conductivity was much greater than anticipated. 



\begin{tabular}{|c|c|c|c|c|c|c|c|c|c|}
\hline $\begin{array}{c}\text { Time } \\
\text { (minutes) }\end{array}$ & $\begin{array}{c}\text { Recovery } \\
\text { (feet) }\end{array}$ & $\begin{array}{c}\text { Time } \\
\text { (minutes) }\end{array}$ & $\begin{array}{l}\text { Recovery } \\
\text { (feet) }\end{array}$ & $\begin{array}{c}\text { Time } \\
\text { (minutes) }\end{array}$ & $\begin{array}{c}\text { Recovery } \\
\text { (feet) }\end{array}$ & $\begin{array}{c}\text { Time } \\
\text { (minutes) }\end{array}$ & $\begin{array}{c}\text { Recovery } \\
\text { (feet) }\end{array}$ & $\begin{array}{c}\text { Time } \\
\text { (minutes) }\end{array}$ & $\begin{array}{c}\text { Recovery } \\
\text { (feet) }\end{array}$ \\
\hline 0 & 0.154 & 0.1833 & 1.035 & 0.5 & 0.774 & 6 & 0.343 & 80 & 0.212 \\
\hline 0.0033 & 0.198 & 0.1866 & 1.035 & 0.5166 & 0.769 & 6.2 & 0.343 & 82 & 0.212 \\
\hline 0.0066 & 0.512 & 0.19 & 1.02 & 0.5333 & 0.764 & 6.4 & 0.338 & 84 & 0.208 \\
\hline 0.01 & $\cdot 1.011$ & 0.1933 & 1.02 & 0.55 & 0.754 & 6.6 & 0.338 & 86 & 0.212 \\
\hline 0.0133 & 1.132 & 0.1966 & 1.02 & 0.5666 & 0.745 & 6.8 & 0.333 & 88 & 0.212 \\
\hline 0.0166 & 0.895 & 0.2 & 1.011 & 0.5833 & 0.74 & 7 & 0.329 & 90 & 0.208 \\
\hline 0.02 & 0.648 & 0.2033 & 1.011 & 0.6 & 0.735 & 7.2 & 0.329 & 92 & 0.212 \\
\hline 0.0233 & 0.696 & 0.2066 & 1.006 & 0.6166 & 0.73 & 7.4 & 0.324 & 94 & 0.212 \\
\hline 0.0266 & 0.382 & 0.21 & 0.996 & 0.6333 & 0.73 & 7.6 & 0.319 & 96 & 0.212 \\
\hline 0.03 & 0.256 & 0.2133 & 0.991 & 0.65 & 0.72 & 7.8 & 0.324 & 98 & 0.208 \\
\hline 0.0333 & 1.615 & 0.2166 & 0.991 & 0.6666 & 0.716 & 8 & 0.314 & 100 & 0.212 \\
\hline 0.0366 & 1.809 & 0.22 & 0.991 & 0.6833 & 0.711 & 8.2 & 0.319 & 120 & 0.212 \\
\hline 0.04 & 1.315 & 0.2233 & 0.991 & 0.7 & 0.706 & 8.4 & 0.309 & 140 & 0.208 \\
\hline 0.0433 & 1.233 & 0.2266 & 0.982 & 0.7166 & 0.696 & 8.6 & 0.309 & 160 & 0.208 \\
\hline 0.0466 & 1.364 & 0.23 & 0.982 & 0.7333 & 0.691 & 8.8 & 0.304 & 180 & 0.208 \\
\hline 0.05 & 1.335 & 0.2333 & 0.977 & 0.75 & 0.691 & 9 & 0.304 & 200 & 0.212 \\
\hline 0.0533 & 1.282 & 0.2366 & 0.977 & 0.7666 & 0.682 & 9.2 & 0.3 & 220 & 0.208 \\
\hline 0.0566 & 1.277 & 0.24 & 0.972 & 0.7833 & 0.677 & 9.4 & 0.304 & 240 & 0.212 \\
\hline 0.06 & 1.286 & 0.2433 & 0.967 & 0.8 & 0.672 & 9.6 & 0.295 & 260 & 0.198 \\
\hline 0.0633 & 1.267 & 0.2466 & 0.962 & 0.8166 & 0.672 & 9.8 & 0.295 & 280 & 0.198 \\
\hline 0.0666 & 1.248 & 0.25 & 0.958 & 0.8333 & 0.667 & 10 & 0.29 & 300 & 0.203 \\
\hline 0.07 & 1.253 & 0.2533 & 0.958 & 0.85 & 0.662 & 12 & 0.285 & 320 & 0.203 \\
\hline 0.0733 & 1.233 & 0.2566 & 0.948 & 0.8666 & 0.662 & 14 & 0.275 & $340^{\circ}$ & 0.203 \\
\hline 0.0766 & 1.224 & 0.26 & 0.953 & 0.8833 & 0.658 & 16 & 0.261 & 360 & 0.198 \\
\hline 0.08 & 1.224 & 0.2633 & 0.943 & 0.9 & 0.653 & 18 & 0.261 & 380 & 0.198 \\
\hline 0.0833 & 1.214 & 0.2666 & 0.948 & 0.9166 & 0.648 & 20 & 0.246 & 400 & 0.203 \\
\hline 0.0866 & 1.209 & 0.27 & 0.938 & 0.9333 & 0.643 & 22 & 0.246 & 420 & 0.193 \\
\hline 0.09 & 1.199 & 0.2733 & 0.928 & 0.95 & 0.643 & 24 & 0.246 & 440 & 0.193 \\
\hline 0.0933 & 1.19 & 0.2766 & 0.933 & 0.9666 & 0.638 & 26 & 0.242 & 460 & 0.193 \\
\hline 0.0966 & 1.185 & 0.28 & 0.933 & 0.9833 & 0.638 & 28 & 0.232 & 480 & 0.188 \\
\hline 0.1 & 1.17 & 0.2833 & 0.928 & 1 & 0.629 & 30 & 0.232 & 500 & 0.193 \\
\hline 0.1033 & 1.17 & 0.2866 & 0.924 & 1.2 & 0.595 & 32 & 0.227 & 520 & 0.188 \\
\hline 0.1066 & 1.166 & 0.29 & 0.919 & 1.4 & 0.566 & 34 & 0.237 & 540 & 0.188 \\
\hline 0.11 & 1.166 & 0.2933 & 0.919 & 1.6 & 0.537 & 36 & 0.227 & 560 & 0.183 \\
\hline 0.1133 & 1.151 & 0.2966 & 0.919 & 1.8 & 0.527 & 38 & 0.227 & 580 & 0.188 \\
\hline 0.1166 & 1.146 & 0.3 & 0.919 & 2 & 0.503 & 40 & 0.227 & 600 & 0.193 \\
\hline 0.12 & 1.141 & 0.3033 & 0.914 & 2.2 & 0.493 & 42 & 0.227 & 620 & 0.193 \\
\hline 0.1233 & 1.132 & 0.3066 & 0.909 & 2.4 & 0.479 & 44 & 0.227 & 640 & 0.193 \\
\hline 0.1266 & 1.132 & 0.31 & 0.904 & 2.6 & 0.469 & 46 & 0.227 & 660 & 0.188 \\
\hline 0.13 & 1.117 & 0.3133 & 0.899 & 2.8 & 0.45 & $48^{\circ}$ & 0.227 & 680 & 0.193 \\
\hline 0.1333 & 1.117 & 0.3166 & 0.899 & 3 & 0.445 & 50 & 0.222 & 700 & 0.188 \\
\hline 0.1366 & 1.107 & 0.32 & 0.899 & 3.2 & 0.43 & 52 & 0.227 & 720 & 0.183 \\
\hline 0.14 & 1.103 & 0.3233 & 0.899 & 3.4 & 0.425 & 54 & 0.222 & 740 & 0.183 \\
\hline 0.1433 & 1.098 & 0.3266 & 0.895 & 3.6 & 0.416 & 56 & 0.217 & 760 & 0.183 \\
\hline 0.1466 & 1.088 & 0.33 & 0.885 & 3.8 & 0.401 & 58 & 0.217 & 780 & 0.188 \\
\hline 0.15 & 1.088 & 0.3333 & 0.89 & 4 & 0.401 & 60 & 0.217 & & \\
\hline 0.1533 & 1.083 & 0.35 & 0.875 & 4.2 & 0.396 & 62 & 0.212 & & \\
\hline 0.1566 & 1.078 & 0.3666 & 0.856 & 4.4 & 0.387 & 64 & 0.217 & & \\
\hline 0.16 & 1.069 & 0.3833 & 0.846 & 4.6 & 0.382 & 66 & 0.222 & & \\
\hline 0.1633 & 1.064 & 0.4 & 0.837 & 4.8 & 0.377 & 68 & 0.217 & & \\
\hline 0.1666 & 1.064 & 0.4166 & 0.827 & 5 & 0.362 & 70 & 0.217 & & \\
\hline 0.17 & 1.054 & 0.4333 & .0 .817 & 5.2 & 0.362 & 72 & 0.212 & & \\
\hline 0.17333 & 1.054 & 0.45 & 0.803 & 5.4 & 0.358 & 74 & 0.217 & & \\
\hline 0.1766 & 1.045 & 0.4666 & 0.793 & 5.6 & 0.353 & 76 & 0.212 & & \\
\hline 0.18 & 1.035 & 0.4833 & 0.783 & 5.8 & 0.353 & 78 & 0.212 & & \\
\hline
\end{tabular}


Appendix $\mathrm{H}$

Summary of Slug Test Relative Drawdown/Recovery

RU-6

\begin{tabular}{|c|c|c|c|c|c|c|c|}
\hline $\begin{array}{c}\text { Time } \\
\text { (minutes) }\end{array}$ & $\begin{array}{c}\text { Recovery } \\
\text { (feet) }\end{array}$ & $\begin{array}{c}\text { Time } \\
\text { (minutes) }\end{array}$ & $\begin{array}{c}\text { Recovery } \\
\text { (feet) }\end{array}$ & $\begin{array}{c}\text { Time } \\
\text { (minutes) }\end{array}$ & $\begin{array}{c}\text { Recovery } \\
\text { (féet) }\end{array}$ & $\begin{array}{c}\text { Time. } \\
\text { (minutes) }\end{array}$ & $\begin{array}{c}\text { Recovery } \\
\text { (feet) }\end{array}$ \\
\hline 0 & -0.009 & 0.1733 & 1.09 & 0.4 & 1.237 & 4.2 & 0.108 \\
\hline 0.0033 & 0.722 & 0.1766 & 1.071 & 0.4166 & 1.222 & 4.4 & 0.08 \\
\hline 0.0066 & 1.142 & 0.18 & 1.048 & 0.4333 & 1.237 & 4.6 & 0.07 \\
\hline 0.01 & 0.028 & 0.1833 & 1.057 & 0.45 & 1.213 & 4.8 & 0.061 \\
\hline 0.0133 & 0.892 & 0.1866 & 1.034 & 0.4666 & 1.204 & 5 & 0.061 \\
\hline 0.0166 & 1.043 & 0.19 & 1.057 . & 0.4833 & 1.189 & $5: 2$ & 0.037 \\
\hline 0.02 & 1.133 & 0.1933 & $1.086^{\circ}$ & 0.5 & 1.185 & 5.4 & 0.047 \\
\hline 0.0233 & 1.024 & 0.1966 & 1.086 & 0.5166 & 1.152 & 5.6 & 0.028 \\
\hline 0.0266 & 1.227 & 0.2 & 1.062 & 0.5333 & 1.142 & 5.8 & 0.033 \\
\hline 0.03 & 1.194 & 0.2033 & 1.076 & 0.55 & 1.142 & 6 & 0.004 \\
\hline 0.0333 & 1.067 & 0.2066 & 1.062 & 0.5666 & 1.128 & 6.2 & 0.014 \\
\hline 0.0366 & 1.109 & 0.21 & 1.052 & 0.5833 & 1.123 & 6.4 & 0.018 \\
\hline 0.04 & 1.251 & 0.2133 & 1.029 & 0.6 & 1.109 & 6.6 & 0.009 \\
\hline 0.0433 & 1.246 & 0.2166 & 1.052 & 0.6166 & 1.114 & 6.8 & -0.014 \\
\hline 0.0466 & 1.142 & 0.22 & 1.043 & 0.6333 & 1.123 & 7 & -0.018 \\
\hline 0.05 & 1.161 & 0.2233 & 1.043 & 0.65 & 1.086 & 7.2 & -0.009 \\
\hline 0.0533 & 1.147 & 0.2266 & 1.043 & 0.6666 & 1.071 & 7.4 & -0.018 \\
\hline 0.0566 & 1.133 & 0.23 & 1.038 & 0.6833 & 1.052 & 7.6 & -0.018 \\
\hline 0.06 & 1.09 & 0.2333 & 1.128 & 0.7 & 1.038 & 7.8 & -0.033 \\
\hline 0.0633 & 1.09 & 0.2366 & 1.142 & 0.7166 & 1.034 & 8 & -0.023 \\
\hline 0.0666 & 1.071 & 0.24 & 1.18 & 0.7333 & 1.029 & 8.2 & -0.023 \\
\hline 0.07 & 1.038 & 0.2433 & 1.156 & 0.75 & 1.015 & 8.4 & -0.037 \\
\hline 0.0733 & 1.029 & 0.2466 & 1.17 & 0.7666 & 1.005 & 8.6 & -0.023 \\
\hline 0.0766 & 1.015 & 0.25 & 1.142 & 0.7833 & 0.986 & 8.8 & -0.033 \\
\hline 0.08 & 1.043 & 0.2533 & 1.114 & 0.8 . & 0.958 & 9 & -0.033 \\
\hline 0.0833 & 1.052 & 0.2566 & 1.133 & 0.8166 & 0.972 & 9.2 & -0.033 \\
\hline 0.0866 & 1.067 & 0.26 & 1.142 & 0.8333 & 0.953 & 9.4 & -0.033 \\
\hline 0.09 & 1.071 & 0.2633 & 1.119 & 0.85 & 0.949 & 9.6 & -0.033 \\
\hline 0.0933 & 1.052 & 0.2666 & 1.123 & 0.8666 & 0.958 & 9.8 & -0.028 \\
\hline 0.0966 & 1.019 & 0.27 & 1.1 & 0.8833 & 0.953 & 10 & -0.033 \\
\hline 0.1 & 1.015 & 0.2733 & 1.119 & 0.9 & 0.953 & 12 & 0.023 \\
\hline 0.1033 & 0.991 & 0.2766 & 1.119 & 0.9166 & 0.953 & 14 & 0.028 \\
\hline 0.1066 & 1.005 & 0.28 & 1.1 & 0.9333 & 0.925 & 16 & 0.042 \\
\hline 0.11 & 1.043 & 0.2833 & 1.095 & 0.95 & 0.944 & 18 & 0.056 \\
\hline 0.1133 & 1.048 & 0.2866 & 1.114 & 0.9666 & 0.911 & 20 & 0.08 \\
\hline 0.1166 & 1.038 & 0.29 & 1.104 & 0.9833 & 0.897 & 22 & 0.118 \\
\hline 0.12 & 1.019 & 0.2933 & 1.081 & 1 & 0.892 & 24 & 0.122 \\
\hline 0.1233 & 1.029 & 0.2966 & 1.119 & 1.2 & 0.746 & 26 & 0.122 \\
\hline 0.1266 & 0.996 & 0.3 & 1.119 & 1.4 & 0.67 & 28 & 0.16 \\
\hline 0.13 & 1.015 & 0.3033 & 1.114 & 1.6 & 0.613 & 30 & 0.151 \\
\hline 0.1333 & 1.043 & 0.3066 & 1.109 & 1.8 & 0.552 & 32 & 0.203 \\
\hline 0.1366 & 1.057 & 0.31 & 1.119 & 2 & 0.472 & 34 & 0.198 \\
\hline 0.14 & 1.052 & 0.3133 & 1.095 & 2.2 & 0.406 & 36 & 0.212 \\
\hline 0.1433 & 1.067 & 0.3166 & 1.123 & 2.4 & 0.373 & 38 & 0.231 \\
\hline 0.1466 & 1.09 & 0.32 & 1.119 & 2.6 & 0.344 & & \\
\hline 0.15 & 1.114 & 0.3233 & 1.123 & 2.8 & 0.311 & & \\
\hline 0.1533 & 1.133 & 0.3266 & 1.123 & 3 & 0.255 & & \\
\hline 0.1566 & 1.137 & 0.33 & 1.123 & 3.2 & 0.212 & & \\
\hline 0.16 & 1.052 & 0.3333 & 1.128 & 3.4 & 0.184 & & \\
\hline 0.1633 & 1.048 & 0.35 & 1.194 & 3.6 & 0.203 & & \\
\hline 0.1666 & 1.067 & 0.3666 & 1.232 & 3.8 & 0.16 & & \\
\hline 0.17 & 1.057 & 0.3833 & 1.237 & 4 & 0.118 & & \\
\hline
\end{tabular}


Appenaix $\mathrm{H}$

Summary of Relative Drawoown

RU-1 and Associated Piezometer

\begin{tabular}{|c|c|c|c|c|c|c|c|c|c|c|c|}
\hline $\begin{array}{c}\text { Time } \\
\text { (minutes) }\end{array}$ & $\begin{array}{l}\text { Piezometer } \\
\text { Drawdown } \\
\text { (feet) }\end{array}$ & $\begin{array}{c}\text { RU-1 } \\
\text { Drawdown } \\
\text { (feet) }\end{array}$ & $\begin{array}{c}\text { Time } \\
\text { (minutes) }\end{array}$ & $\begin{array}{l}\text { Piezometer } \\
\text { Drawdown } \\
\text { (feet) }\end{array}$ & $\begin{array}{c}\text { RU-1 } \\
\text { Drawdown } \\
\text { (feet) }\end{array}$ & $\begin{array}{c}\text { Time } \\
\text { (minutes) }\end{array}$ & $\begin{array}{l}\text { Piezometer } \\
\text { Drawdown } \\
\text { (feet) }\end{array}$ & $\begin{array}{c}\text { RU-1 } \\
\text { Drawdown } \\
\text { (feet) }\end{array}$ & $\begin{array}{c}\text { Time } \\
\text { (minutes) }\end{array}$ & $\begin{array}{l}\text { Piezometer } \\
\text { Drawdown } \\
\text { (feet) }\end{array}$ & $\begin{array}{c}\text { RU-1 } \\
\text { Drawdown } \\
\text { (feet) }\end{array}$ \\
\hline 0.0000 & 0.0090 & -0.0040 & 0.2166 & -0.1980 & 0.1300 & 0.8333 & -0.2730 & $0.3230^{\circ}$ & 30.0000 & -0.0610 & $1.0870^{\circ}$ \\
\hline 0,0033 & -0.1980 & -0.0040 & 0.2200 & -0.2070 & 0.1350 & 0.8500 & -0.2350 & 0.3230 & 32.0000 & -0.1320 & 1.1020 \\
\hline 0,0066 & -0.4480 & -0.0040 & 0.2233 & -0.1980 & 0.1350 & 0.8666 & -0.2400 & 0.3280 & 34.0000 & -0.0800 & 1.1160 \\
\hline 0.0100 & -0.1360 & 0.0000 & 0.2266 & -0.2500 & 0.1350 & 0.8833 & -0.2120 & $0.3330^{\circ}$ & 36.0000 & -0.0750 & 1.1310 \\
\hline 0.0133 & $\cdot 0.2540$ & -0.0040 & 0.2300 & -0.1650 & 0.1400 & 0.9000 & -0.2540 & 0.3380 & 38.0000 & -0.1600 & 1.1400 \\
\hline 0.0166 & -0.4900 & -0.0040 & 0.2333 & -0.1840 & 0.1400 & 0.9166 & $-0.212 p$ & 0.3430 & 40.0000 & -0.1130 & 1.1500 \\
\hline 0,0200 & -0.4240 & 0.0000 & 0.2366 & -0.2170 & 0.1450 & 0.9333 & -0.2970 & 0.3380 & 42.0000 & -0.1550 & 1.1550 \\
\hline 0.0233 & -0.3160 & -0.0040 & 0.2400 & -0.2500 & 0.1450 & 0.9500 & -0.2260 & 0.3480 & 44.0000 & 0.0000 & 1.1650 \\
\hline 0.0266 & -0.3160 & -0.0040 & 0.2433 & -0.2310 & 0.1490 & 0.9666 & -0.3300 & 0.3480 & 46.0000 & -0.0660 & 1.1690 \\
\hline 0.0300 & -0.3580 & -0.0040 & 0.2466 & -0.1460 & 0.1450 & 0.9833 & -0.2170 & 0.3520 & 48.0000 & -0.0140 & 1.1840 \\
\hline 0.0333 & -0.2870 & $\cdot 0.0040$ & 0.2500 & -0.2500 & 0.1490 & 1.0000 & -0.2830 & 0.3480 & 50.0000 & -0.0280 & 1.1890 \\
\hline 0.0366 & -0.2350 & 0.0000 & 0.2533 & -0.2450 & 0.1490 & 1.2000 & -0.2450 & 0.3810 & 52.0000 & -0.0230 & 1.1940 \\
\hline 0.0400 & $\cdot 0.1410$ & -0.0040 & 0.2566 & -0.2310 & 0.1540 & 1.4000 & -0.2450 & 0.4010 & 54.0000 & -0.0610 & 1.2030 \\
\hline 0.0433 & -0.2260 & 0.0000 & 0.2600 & -0.2260 & 0.1540 & 1.6000 & -0.1840 & 0.4200 & 56.0000 & -0.0230 & 1.2080 \\
\hline 0.0466 & -0.2540 & 0.0000 & 0.2633 & -0.1980 & 0.1590 & 1.8000 & -0.2590 & 0.4350 & 58.0000 & -0.0280 & 1.2130 \\
\hline 0.0500 & -0.2260 & 0.0000 & 0.2666 & -0.2450 & 0.1590 & 2.0000 & -0.2350 & 0.4540 & 60.0000 & -0.0370 & 1.2130 \\
\hline 0.0 .533 & $\cdot 0.2870$ & 0.0040 & 0.2700 & -0.2070 & 0.1590 & 2.2000 & -0.2070 & 0.4680 & 62.0000 & -0.0660 & 1.2180 \\
\hline 0.0566 & -0.2920 & 0.0040 & 0.2733 & -0.2540 & 0.1640 & 2.4000 & -0.1930 & 0.4880 & 64.0000 & -0.0510 & 1.2230 \\
\hline 0.0600 & $\cdot 0.2970$ & 0.0040 & 0.2766 & -0.2830 & 0.1690 & 2.6000 & -0.2170 & 0.5020 & 66.0000 & -0.0230 & 1.2270 \\
\hline 0.0633 & -0.2590 & 0.0090 & 0.2800 & -0.2070 & 0.1690 & 2.8000 & -0.1790 & 0.5170 & 68.0000 & 0.0040 & 1.2270 \\
\hline 0.0666 & -0.1460 & 0.0140 & 0.2833 & -0.2210 & 0.1640 & 3.0000 & -0.2310 & 0.5310 & 70.0000 & 0.0000 & 1.2320 \\
\hline 0.0700 & .0 .1930 & 0.0140 & 0.2866 & -0.2170 & 0.1690 & 3.2000 & -0.2540 & 0.5410 & 72.0000 & -0.0230 & 1.2370 \\
\hline 0.0733 & -0.2640 & 0.0190 & 0.2900 & -0.3160 & 0.1690 & 3.4000 & -0.1740 & 0.5510 & 74.0000 & -0.0610 & 1.2370 \\
\hline 0.0766 & -0.2120 & 0.0190 & 0.2933 & -0.2590 & 0.1690 & 3.6000 & -0.1650 & 0.5650 & 76.0000 & 0.0610 & 1.2420 \\
\hline 0.0800 & -0.1170 & 0.0240 & 0.2966 & -0.1980 & 0.1740 & 3.8000 & -0.1790 & 0.5700 & 78.0000 & 0.0560 & 1.2420 \\
\hline 0.0833 & -0.1740 & 0.0290 & 0.3000 & -0.2210 & 0.1740 & 4.0000 & -0.1510 & 0.5800 & 80.0000 & -0.0610 & 1.2470 \\
\hline 0.0866 & -0.1460 & 0.0290 & 0.3033 & $=0.2400$ & 0.1740 & 4.2000 & -0.1930 & 0.5890 & 82.0000 & -0.0140 & 1.2520 \\
\hline 0.0900 & -0.1790 & 0.0330 & 0.3066 & -0.2640 & 0.1780 & 4.4000 & -0.1790 & 0.5940 & 84.0000 & -0.0180 & 1.2560 \\
\hline 0.0933 & -0.1510 & 0.0380 & 0.3100 & -0.1840 & 0.1780 & 4.6000 & -0.1740 & 0.6090 & 86.0000 & 0.0040 & 1.2520 \\
\hline 0.0966 & $\cdot 0.1550$ & 0.0380 & 0.3133 & -0.2310 & 0.1780 & 4.8000 & -0.1980 & 0.6180 & 88.0000 & 0.0090 & 1.2520 \\
\hline 0,1000 & -0.1980 & 0.0430 & 0.3166 & -0.2020 & 0.1880 & 5.0000 & -0.2350 & 0.6330 & 90.0000 & -0.0330 & 1.2560 \\
\hline 0.1033 & -0.1360 & 0.0480 & 0.3200 & -0.1880 & 0.1830 & 5.2000 & -0.1980 & 0.6420 & 92.0000 & 0.0370 & 1.2560 \\
\hline 0.1066 & -0.2070 & 0.0480 & 0.3233 & -0.1980 & 0.1830 & $5.40,00$ & -0.1550 & 0.6520 & 94.0000 & -0.0090 & 1.2560 \\
\hline 0.1100 & -0.2070 & 0.0530 & 0.3266 & -0.2400 & 0.1930 & 5.6000 & -0.1880 & 0.6670 & 96.0000 & 0.0230 & 1.2610 \\
\hline 0.1133 & -0.1740 & 0.0580 & 0.3300 & -0.2450 & 0.1880 & 5.8000 & -0.2120 & 0.6760 & 98.0000 & 0.0510 & 1.2560 \\
\hline 0.1166 & -0.1550 & 0.0620 & 0.3333 & -0.1510 & 0.1930 & 6.0000 & -0.1840 & 0.6760 & 100.0000 & 0.0230 & 1.2560 \\
\hline 0.1200 & -0.1550 & 0.0620 & 0.3500 & -0.0140 & 0.1980 & 6.2000 & -0.2070 & 0.6810 & 120.0000 & 0.0330 & 1.2710 \\
\hline 0.1233 & -0.2780 & 0.0670 & 0.3666 & -0.1130 & 0.1980 & 6.4000 & -0.2070 & 0.6860 & 140.0000 & 0.1510 & 1.2660 \\
\hline 0.1266 & -0.2350 & 0.0670 & 0.3833 & -0.0840 & 0.2120 & 6.6000 & -0.1650 . & 0.6910 & 160.0000 & 0.1360 & 1.2850 \\
\hline 0,1300 & -0.2170 & 0.0720 & 0.4000 & -0.1080 & 0.2170 & 6.8000 & $-0.1460^{\circ}$ & 0.7000 & 180.0000 & 0.1170 & 1.3000 \\
\hline 0.1333 & -0.2500 & 0.0770 & 0.4166 & -0.1320 & 0.2270 & 7.0000 & -0.1220 & 0.7000 & 200.0000 & 0.1270 & 1.3000 \\
\hline 0.1366 & -0.2780 & 0.0720 & 0.4333 & -0.0990 & 0.2270 & 7.2000 & -0.1840 & .0 .7050 & 220.0000 & 0.2210 & 1.3190 \\
\hline 0.1400 & -0.2970 & 0.0820 & 0.4500 & -0.1220 & 0.2320 & 7.4000 & -0.1220 & 0.7100 & 240.0000 & 0.2170 & $1.3190^{\circ}$ \\
\hline 0.1433 & -0.2730 & 0.0820 & 0.4666 & -0.1220 & 0.2410 & 7.6000 & -0.2070 & 0.7150 & 260.0000 & 0.2350 & 1.3140 \\
\hline 0.1466 & -0.2310 & 0.0820 & 0.4833 & -0.1550 & 0.2460 & 7.8000 & -0.1650 & 0.7250 & 280.0000 & 0.3530 & 1.3050 \\
\hline 0.1500 & -0.2920 & 0.0870 & 0.5000 & -0.2070 & 0.2510 & 8.0000 & -0.1650 & 0.7250 & 300.0000 & 0.2780 & 1.3140 \\
\hline 0.1533 & -0.2780 & 0.0910 & 0.5166 & -0.1980 & 0.2560 & 8.2000 & -0.1840 & 0.7300 & 320.0000 & 0.2970 & 1.3240 \\
\hline 0.1566 & -0.2260 & 0.0870 & 0.5333 & -0.1790 & 0.2610 & 8.4000 & -0.1880 & 0.7340 & 340.0000 & 0.2920 & 1.3240 \\
\hline 0.1600 & -0.2690 & 0.0910 & 0.5500 & -0.1980 & 0.2650 & 8.6000 & -0.1790 & 0.7390 & 360.0000 & 0.2870 & 1.3340 \\
\hline 0.1633 & -0.2350 & 0.0910 & 0.5666 & -0.1220 & 0.2700 & 8.8000 & -0.1360 & 0.7490 & 380.0000 & 0.3630 & 1.3390 \\
\hline 0.1666 & -0.1980 & 0.1010 & 0.5833 & -0.2120 & 0.2750 & 9.0000 & -0.1930 & 0.7490 & 400.0000 & 0.3250 & 1.3340 \\
\hline 0.1700 & -0.2450 & 0.1010 & 0.6000 & -0.1270 & 0.2800 & 9.2000 & -0.2210 & 0.7540 & 420.0000 & 0.3630 & 1.3340 \\
\hline 0.1733 & -0.2310 & 0.1010 & 0.6166 & -0.2310 & 0.2800 & 9.4000 & -0.1840 & 0.7630 & 440.0000 & 0.2170 & 1.3340 \\
\hline 0.1766 & -0.2350 & 0.1010 & 0.6333 & -0.1930 & 0.2850 & 9.6000 & -0.1650 & 0.7680 & 460.0000 & 0.1880 & 1.3240 \\
\hline 0.1800 & -0.2020 & 0.1060 & 0.6500 & -0.2310 & 0.2940 & 9.8000 & -0.1550 & 0.7780 & 480.0000 & 0.2970 & 1.3050 \\
\hline 0.1833 & -0.1740 & 0.1110 & 0.6666 & -0.2400 & 0.2900 & 10.0000 & -0.1690 & 0.7780 & & & \\
\hline 0.1866 & -0.2730 & 0.1160 & 0.6833 & -0.2120 & 0.2940 & 12.0000 & -0.1690 & 0.8500 & & & \\
\hline 0.1900 & $\cdot 0.2260$ & $0: 1160$ & 0.7000 & -0.2310 & 0.2990 & 14.0000 & -0.1690 & 0.8940 & & & \\
\hline 0.1933 & -0.1840 & 0.1200 & 0.7166 & -0.1880 & 0.3040 & 16.0000 & -0.2310 & 0.9280 & & & \\
\hline 0.1966 & -0.1690 & 0.1200 & 0.7333 & -0.2120 & 0.3040 & 18.0000 & -0.1170 & 0.9620 & & ${ }^{\circ}$ & \\
\hline 0.2000 & -0.2070 & 0.1200 & 0.7500 & -0.1930 & 0.3090 & 20.0000 & -0.1650 & 0.9860 & & & \\
\hline 0,2033 & -0.2590 & 0.1250 & 0.7666 & -0.2400 & 0.3090 & 22.0000 & -0.0840 & 1.0150 & & & \\
\hline 0,2066 & -0.1930 & 0.1250 & 0.7833 & -0.2640 & 0.3190 & 24.0000 & -0.0280 & 1.0390 & & & \\
\hline 0,2100 & $\cdot 0.2170$ & 0.1250 & 0.8000 & -0.2640 & 0.3190 & 26.0000 & -0.1360 & 1.0530 & & & \\
\hline 0.2133 & -0.2170 & 0.1250 & 0.8166 & -0.2780 & 0.3230 & 28.0000 & -0.0560 & 1.0780 & & & \\
\hline
\end{tabular}




\begin{tabular}{|c|c|c|c|c|c|c|c|c|c|c|c|}
\hline $\begin{array}{c}\text { Time } \\
\text { (minutes) }\end{array}$ & $\begin{array}{c}\text { Piezometer } \\
\text { Recovery } \\
\text { (feet) }\end{array}$ & $\begin{array}{c}\text { RU-1 } \\
\text { Recovery } \\
\text { (feet) }\end{array}$ & $\begin{array}{c}\text { Time } \\
\text { (minutes) }\end{array}$ & $\begin{array}{c}\text { Piezometer } \\
\text { Recovery } \\
\text { (feet) }\end{array}$ & $\begin{array}{c}\text { RU-1 } \\
\text { Recovery } \\
\text { (ieel) }\end{array}$ & $\begin{array}{c}\text { Time } \\
\text { (minutes) }\end{array}$ & $\begin{array}{c}\text { Piezometer } \\
\text { - Recovery } \\
\text { (feet) }\end{array}$ & $\begin{array}{c}\text { RU-1 } \\
\text { Recovery } \\
\text { (feet) }\end{array}$ & $\begin{array}{c}\text { Time } \\
\text { (minutes) }\end{array}$ & $\begin{array}{l}\text { Piezometer } \\
\text { Recovery } \\
\text { (feet) }\end{array}$ & $\begin{array}{c}\text { RU-1 } \\
\text { Recovery } \\
\text { (feet) }\end{array}$ \\
\hline 0.0000 & 0.2210 & 1.3290 & 0.2166 & -0.1270 & 1.1650 & 0.8333 & -0.0610 & 0.9710 & 30.0000 & -0.1130 & 0.2700 \\
\hline 0.0033 & 0.1360 & 1.3190 & 0.2200 & -0.1080 & 1.1740 & 0.8500 & -0.0660 & 0.9660 & 32.0000 & -0.1320 & 0.2610 \\
\hline 0.0066 & 0.0700 & 1.3240 & 0.2233 & -0.1030 & 1.1650 & 0.8666 & -0.0840 & 0.9710 & 34.0000 & -0.1080 & 0.2410 \\
\hline 0.0100 & 0.0000 & 1.3240 & 0.2266 & -0.1510 & 1.1650 & 0.8833 & -0.0890 & 0.9710 & 36.0000 & -0.1360 & 0.2410 \\
\hline 0.0133 & 0.0180 & 1.3190 & 0.2300 & -0.1460 & 1.1550 & 0.9000 & -0.0840 & 0.9620 & 38.0000 & -0.1840 & 0.2270 \\
\hline 0.0166 & 0.1170 & 1.3140 & 0.2333 & -0.1320 & 1.1500 & 0.9166 & -0.0750 & 0.9620 & 40.0000 & -0.1740 & 0.2220 \\
\hline 0.0200 & 0.0560 & 1.3100 & 0.2366 & -0.1410 & 1.1550 & 0.9333 & -0.0610 & 0.9570 & 42.0000 & -0.1220 & 0.2070 \\
\hline 0.0233 & 0.0660 & 1.3100 & 0.2400 & -0.1690 & 1.1550 & 0.9500 & -0.0660 & 0.9520 & 44.0000 & -0.1360 & 0.2070 \\
\hline 0.0266 & 0.0800 & 1.3140 & 0.2433 & -0.1510 & 1.1550 & 0.9666 & -0.0800 & 0.9470 & 46.0000 & -0.1980 & 0.1980 \\
\hline 0.0300 & $\cdot 0.0420$ & 1.3050 & 0.2466 & -0.1270 & 1.1500 & 0.9833 & -0.1220 & 0.9470 & 48.0000 & -0.1650 & 0.1880 \\
\hline 0.0333 & 0.0140 & 1.3050 & 0.2500 & -0.1460 & 1.1450 & 1.0000 & -0.1170 & 0.9470 & 50.0000 & -0.1130 & 0.1880 \\
\hline 0.0366 & -0.0090 & 1.2950 & 0.2533 & -0.1650 & 1.1450 & 1.2000 & -0.1030 & 0.9080 & 52.0000 & -0.1690 & 0.1830 \\
\hline 0.0400 & 0.0000 & 1.2950 & 0.2566 & -0.1460 & 1.1450 & 1.4000 & -0.1170 & 0.8890 & 54.0000 & -0.1410 & 0.1740 \\
\hline 0.0433 & -0.0180 & 1.2900 & 0.2600 & -0.1410 & 1.1450 & 1.6000 & -0.1030 & 0.8650 & 56.0000 & -0.2070 & 0.1740 \\
\hline 0.0466 & -0.0370 & 1.2850 & 0.2633 & -0.1650 & 1.1450 & 1.8000 & -0.0510 & 0.8410 & 58.0000 & -0.1930 & 0.1690 \\
\hline 0.0500 & 0.0000 & 1.2850 & 0.2666 & -0.1740 & 1.1400 & 2.0000 & -0.0560 & 0.8210 & 60.0000 & -0.1600 & 0.1690 \\
\hline 0.0533 & -0.0230 & 1.2760 & 0.2700 & -0.1550 & 1.1450 & 2.2000 & -0.0700 & 0.8070 & 62.0000 & -0.1550 & 0.1640 \\
\hline 0.0566 & -0.0560 & 1.2760 & 0.2733 & .0 .1320 & 1.1400 & 2.4000 & -0.0890 & 0.7870 & 64.0000 & -0.1510 & 0.1540 \\
\hline 0.0600 & -0.0370 & 1.2760 & 0.2766 & -0.1690 & 1.1310 & 2.6000 & -0.1130 & 0.7680 & 66.0000 & -0.1740 & 0.1450 \\
\hline 0.0633 & -0.0140 & 1.2710 & 0.2800 & -0.1690 & 1.1360 & 2.8000 & -0.1410 & 0.7630 & 68.0000 & -0.2070 & 0.1490 \\
\hline 0.0666 & -0.0420 & 1.2710 & 0.2833 & -0.1360 & 1.1310 & 3.0000 & -0.1220 & 0.7390 & $\cdot 70.0000$ & -0.1650 & 0.1450 \\
\hline 0.0700 & -0.0750 & 1.2610 & 0.2866 & -0.1460 & 1.1360 & 3.2000 & -0.1170 & 0.7340 & 72.0000 & -0.1790 & 0.1350 \\
\hline 0.0733 & -0.0510 & 1.2610 & 0.2900 & -0.1690 & 1.1310 & 3.4000 & -0.0840 & 0.7200 & 74.0000 & -0.1650 & 0.1450 \\
\hline 0.0766 & -0.0420 & 1.2560 & 0.2933 & -0.1550 & 1.1260 & 3.6000 & -0.0890 & 0.7100 & 76.0000 & -0.1600 & 0.1300 \\
\hline 0.0800 & -0.0750 & 1.2560 & 0.2966 & -0.1220 & 1.1310 & 3.8000 & -0.1080 & 0.7000 & 78.0000 & -0.1840 & 0.1400 \\
\hline 0.0833 & -0.0890 & 1.2610 & 0.3000 & -0.1410 & 1.1210 & 4.0000 & -0.1170 & 0.6910 & 80.0000 & -0.1980 & 0.1250 \\
\hline 0.0866 & -0.0750 & 1.2560 & 0.3033 & -0.1360 & 1.1310 & 4.2000 & -0.1460 & 0.6810 & 82.0000 & -0.1690 & 0.1300 \\
\hline 0.0900 & -0.0800 & 1.2470 & 0.3066 & -0.1320 & 1.1210 & 4.4000 & -0.1270 & 0.6710 & 84.0000 & -0.1840 & 0.1250 \\
\hline 0.0933 & -0.1220 & 1.2420 & 0.3100 & -0.1030 & 1.1160 & 4.6000 & -0.1170 & 0.6570 & 86.0000 & -0.2070 & 0.1200 \\
\hline 0.0966 & -0.1080 & 1.2420 & 0.3133 & -0.1410 & 1.1160 & 4.8000 & -0.1170 & 0.6520 & 88.0000 & -0.1030 & 0.1250 \\
\hline 0.1000 & -0.0800 & 1.2420 & 0.3166 & -0.1550 & 1.1210 & 5.0000 & -0.1080 & 0.6470 & 90.0000 & -0.1080 & 0.1160 \\
\hline 0.1033 & -0.1270 & 1.2370 & 0.3200 & -0.1030 & 1.1210 & 5.2000 & -0.1030 & 0.6420 & 92.0000 & -0.0890 & 0.1110 \\
\hline 0.1066 & -0.1460 & 1.2420 & 0.3233 & -0.1030 & 1.1160 & 5.4000 & -0.1550 & 0.6330 & 94.0000 & -0.1130 & 0.1160 \\
\hline 0.1100 & -0.1030 & 1.2320 & 0.3266 & -0.1220 & 1.1110 & 5.6000 & -0.1650 & 0.6230 & 96.0000 & -0.1550 & 0.1110 \\
\hline 0.1133 & -0.0940 & 1.2320 & 0.3300 & -0.1220 & 1.1160 & 5.8000 & -0.1650 & 0.6130 & 98.0000 & -0.0890 & 0.1060 \\
\hline 0.1166 & -0.1080 & 1.2320 & 0.3333 & -0.0700 & 1.1160 & 6.0000 & -0.1690 & 0.6040 & 100.0000 & -0.1360 & 0.1010 \\
\hline 0.1200 & -0.1030 & 1.2270 & 0.3500 & 0.0230 & 1.1020 & 6.2000 & -0.1600 & 0.6090 & 120.0000 & -0.0840 & 0.0770 \\
\hline 0.1233 & -0.0660 & 1.2230 & 0.3666 & -0.0040 & 1.0970 & 6.4000 & -0.1790 & 0.6040 & 140.0000 & -0.0990 & 0.0620 \\
\hline 0.1266 & -0.0800 & 1.2230 & 0.3833 & -0.0180 & 1.0870 & 6.6000 & -0.1320 & 0.5890 & 160.0000 & -0.0660 & 0.0530 \\
\hline 0.1300 & -0.1220 & 1.2180 & 0.4000 & -0.0230 & 1.0870 & 6.8000 & -0.1220 & 0.5840 & 180.0000 & -0.0800 & 0.1060 \\
\hline 0.1333 & -0.0940 & 1.2180 & 0.4166 & -0.0280 & 1.0730 & 7.0000 & -0.1130 & 0.5800 & 200.0000 & -0.0750 & 0.1830 \\
\hline 0.1366 & -0.0800 & 1.2180 & 0.4333 & -0.0280 & 1.0730 & 7.2000 & -0.1030 & 0.5700 & 220.0000 & -0.0470 & 0.2030 \\
\hline 0.1400 & -0.1130 & 1.2180 & 0.4500 & -0.0140 & 1.0680 & 7.4000 & -0.1460 & 0.5750 & 240.0000 & 0.0510 & 0.2070 \\
\hline 0.1433 & -0.1080 & 1.2080 & 0.4666 & -0.0230 & 1.0630 & 7.6000 & -0.1600 & 0.5600 & 260.0000 & 0.0660 & 0.2170 \\
\hline 0.1466 & -0.0840 & 1.2080 & 0.4833 & -0.0280 & 1.0580 & 7.8000 & -0.1170 & 0.5550 & 280.0000 & 0.0000 & 0.2170 \\
\hline 0.1500 & -0.0890 & 1.2130 & 0.5000 & -0.0420 & 1.0530 & 8.0000 & -0.1030 & 0.5510 & 300.0000 & -0.0700 & 0.2220 \\
\hline 0.1533 & -0.1220 & 1.2030 & 0.5166 & -0.0660 & 1.0440 & 8.2000 & -0.1320 & 0.5460 & 320.0000 & 0.0560 & 0.2360 \\
\hline 0.1566 & -0.1030 & 1.2030 & 0.5333 & -0.0840 & 1.0490 & 8.4000 & -0.1600 & 0.5360 & 340.0000 & 0.0140 & 0.2270 \\
\hline 0.1600 & -0.0800 & 1.1940 & 0.5500 & -0.0700 & 1.0390 & 8.6000 & -0.1600 & 0.5410 & 360.0000 & 0.0610 & 0.2270 \\
\hline 0.1633 & -0.0940 & 1.1980 & 0.5666 & -0.0610 & 1.0340 & 8.8000 & -0.1360 & 0.5310 & 380.0000 & -0.0040 & 0.2220 \\
\hline 0.1666 & -0.1170 & 1.1940 & 0.5833 & -0.0800 & 1.0240 & 9.0000 & -0.1170 & 0.5260 & 400.0000 & 0.0370 & 0.2220 \\
\hline 0.1700 & -0.0940 & 1.1940 & 0.6000 & -0.0560 & 1.0290 & 9.2000 & -0.1170 & 0.5220 & 420.0000 & 0.0090 & 0.2270 \\
\hline 0.1733 & -0.0660 & 1.1940 & 0.6166 & -0.0660 & 1.0240 & 9.4000 & -0.1320 & 0.5170 & 440.0000 & 0.0510 & 0.2220 \\
\hline 0.1766 & -0.0890 & 1.1940 & 0.6333 & -0.0230 & 1.0150 & 9.6000 & -0.1550 & 0.5220 & 460.0000 & 0.1030 & 0.2270 \\
\hline 0.1800 & -0.0990 & 1.1890 & 0.6500 & -0.0510 & 1.0150 & 9.8000 . & -0.1690 & 0.5120 & 480.0000 & 0.0750 & 0.2320 \\
\hline 0.1833 & -0.0700 & 1.1840 & 0.6666 & -0.0280 & 1.0100 & 10.0000 & -0.1320 & 0.5070 & 500.0000 & 0.0890 & 0.2320 \\
\hline 0.1866 & -0.0700 & 1.1840 & 0.6833 & -0.0990 & 1.0050 & 12.0000 & -0.1170 & 0.4680 & 520.0000 & 0.0750 & 0.2360 \\
\hline 0.1900 & -0.0890 & 1.1840 & 0.7000 & -0.0990 & 1.0050 & 14.0000 & -0.1220 & 0.4350 & & & \\
\hline 0.1933 & -0.0990 & 1.1840 & 0.7166 & -0.0940 & 1.0050 & 16.0000 & -0.1270 & 0.4060 & & & \\
\hline 0.1966 & -0.0700 & 1.1740 & 0.7333 & -0.0700 & 0.9910 & 18.0000 & -0.1550 & 0.3810 & & & \\
\hline 0.2000 & -0.0800 & 1.1740 & 0.7500 & -0.0420 & 0.9910 & 20.0000 & -0.1360 & 0.3570 & & & \\
\hline 0.2033 & -0.1080 & 1.1740 & 0.7666 & -0.0230 & 0.9860 & 22.0000 & -0.1360 & 0.3330 & & & \\
\hline 0.2066 & -0.0940 & 1.1690 & 0.7833 & -0.0090 & 0.9860 & 24.0000 & -0.1030 & 0.3090 & & & \\
\hline 0.2100 & -0.0750 & 1.1690 & 0.8000 & 0.0000 & 0.9810 & 26.0000 & -0.1410 & 0.2990 & & & \\
\hline 0.2133 & -0.0940 & 1.1690 & 0.8166 & -0.0140 & 0.9760 & 28.0000 & -0.1220 & 0.2850 & & & \\
\hline
\end{tabular}



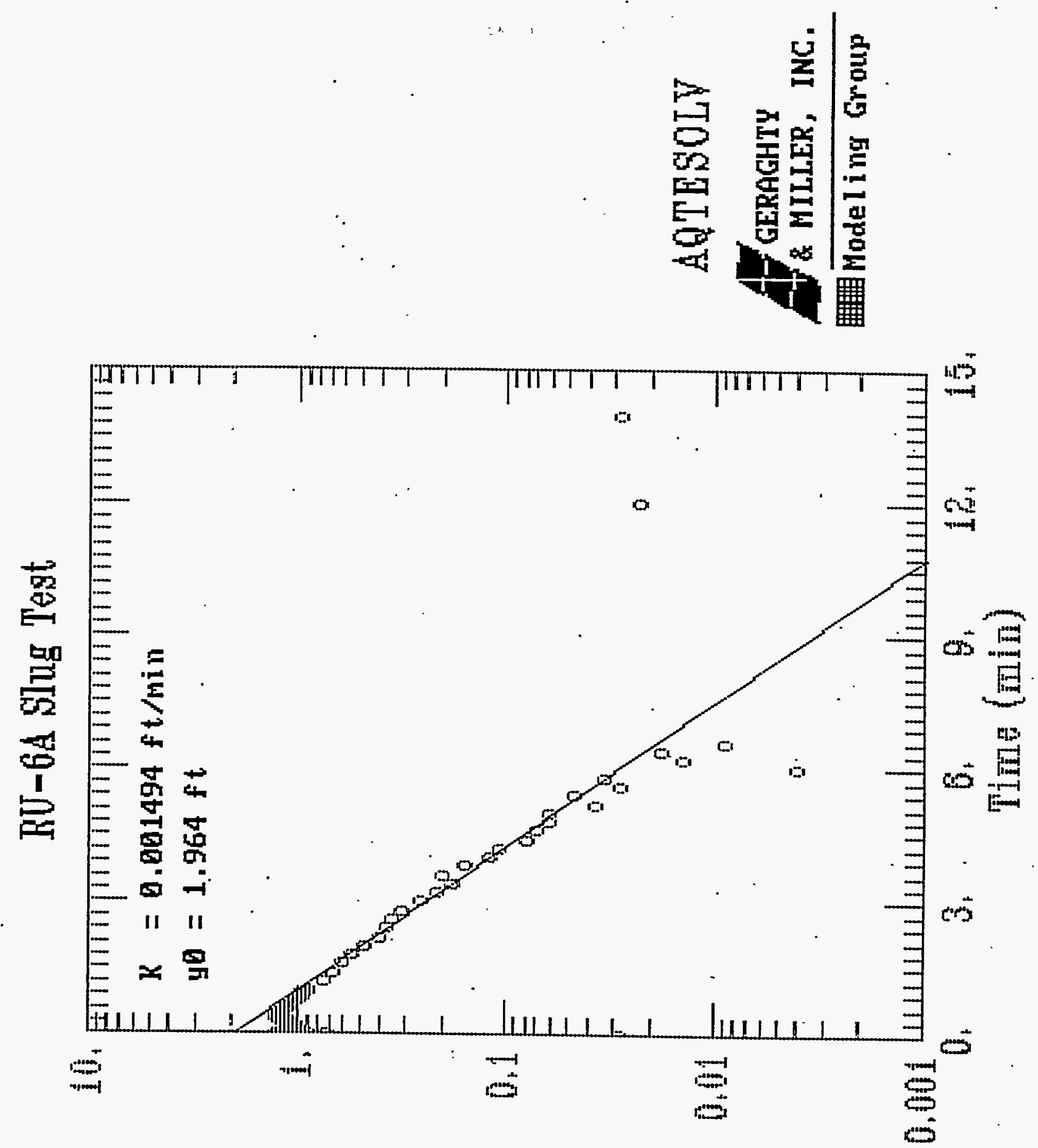

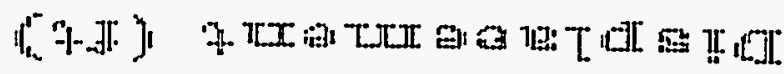




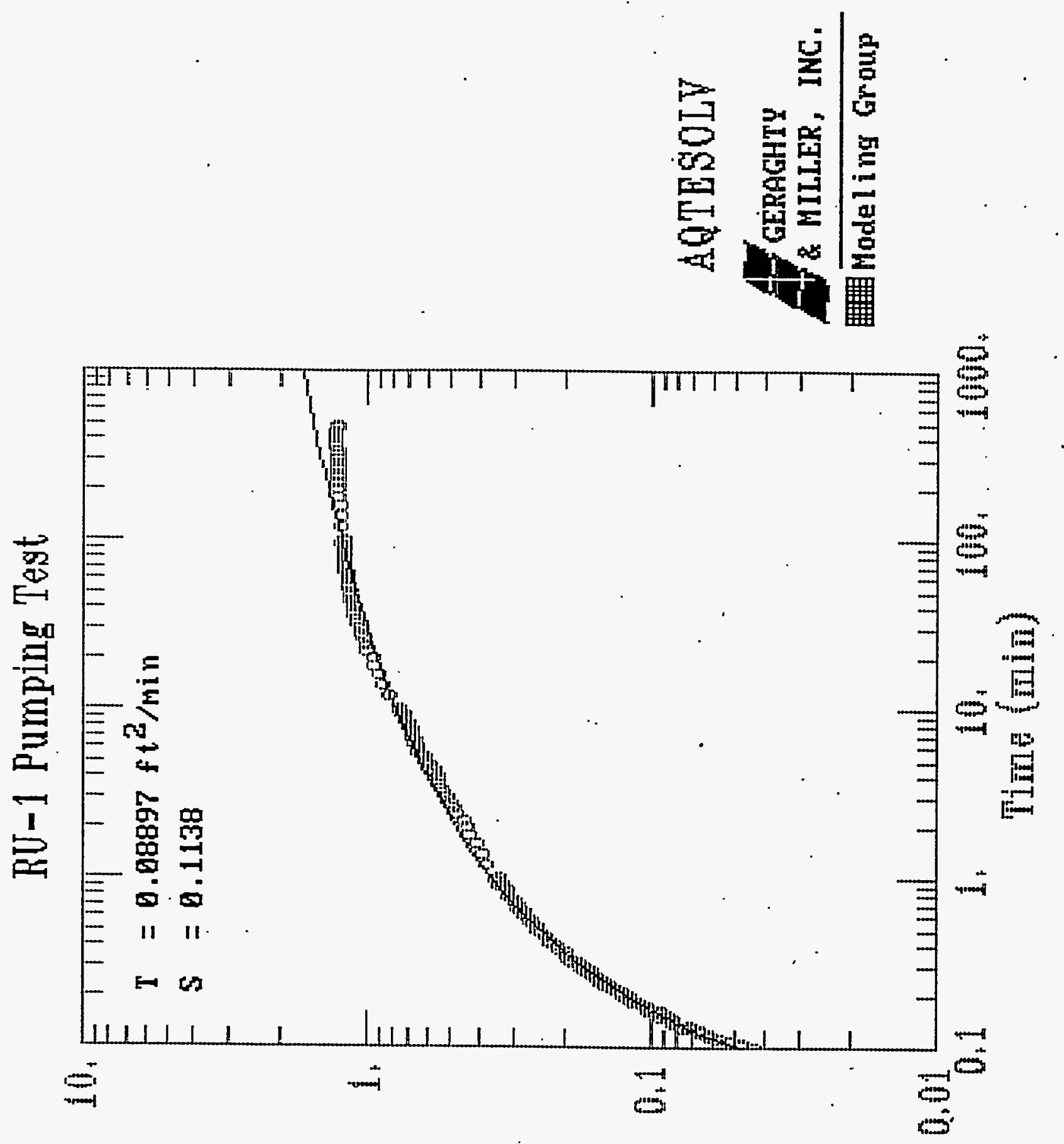

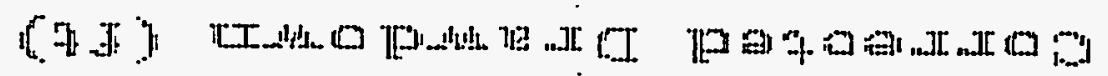


RU-1 Pumping Well Recovery Analysis

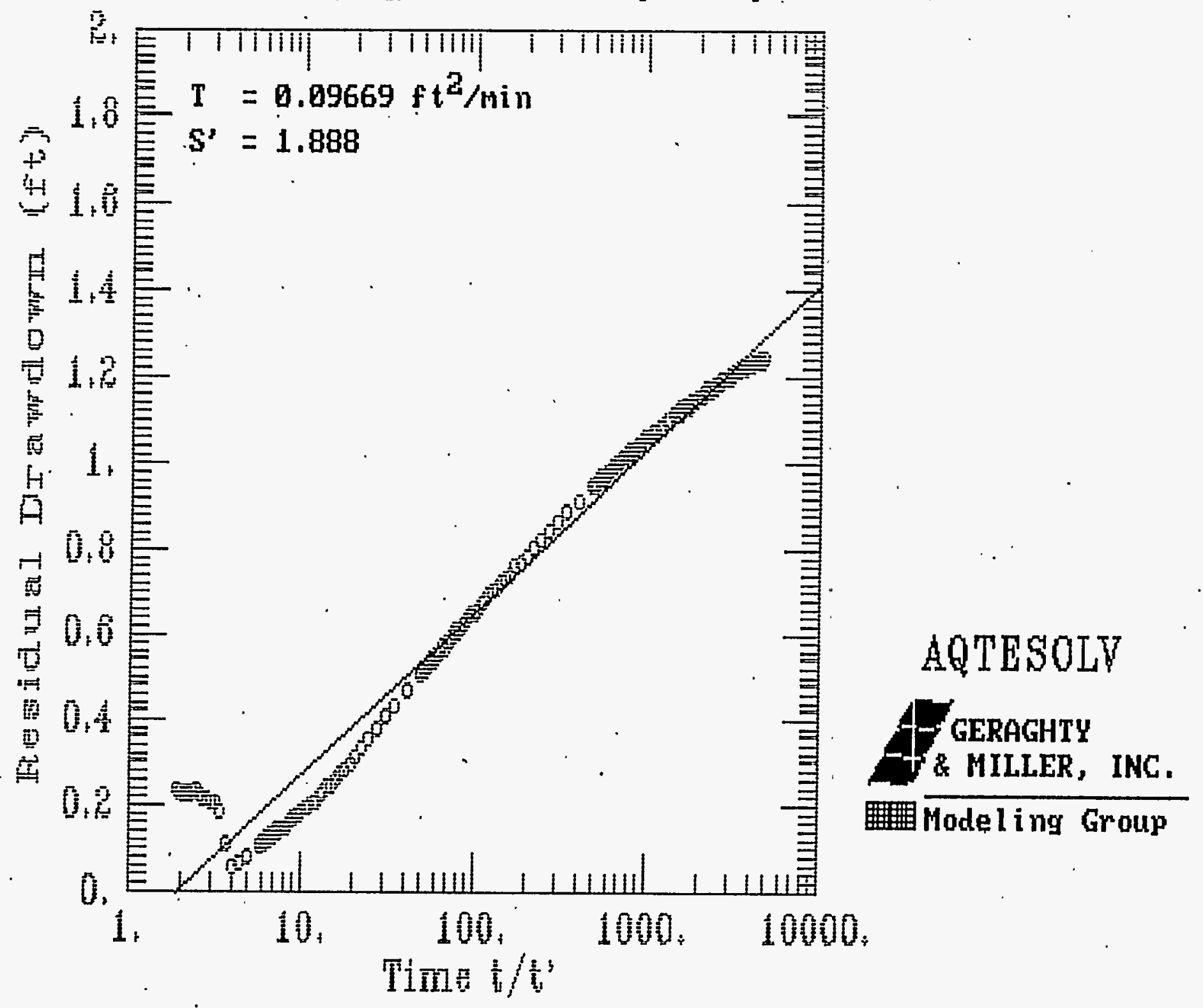



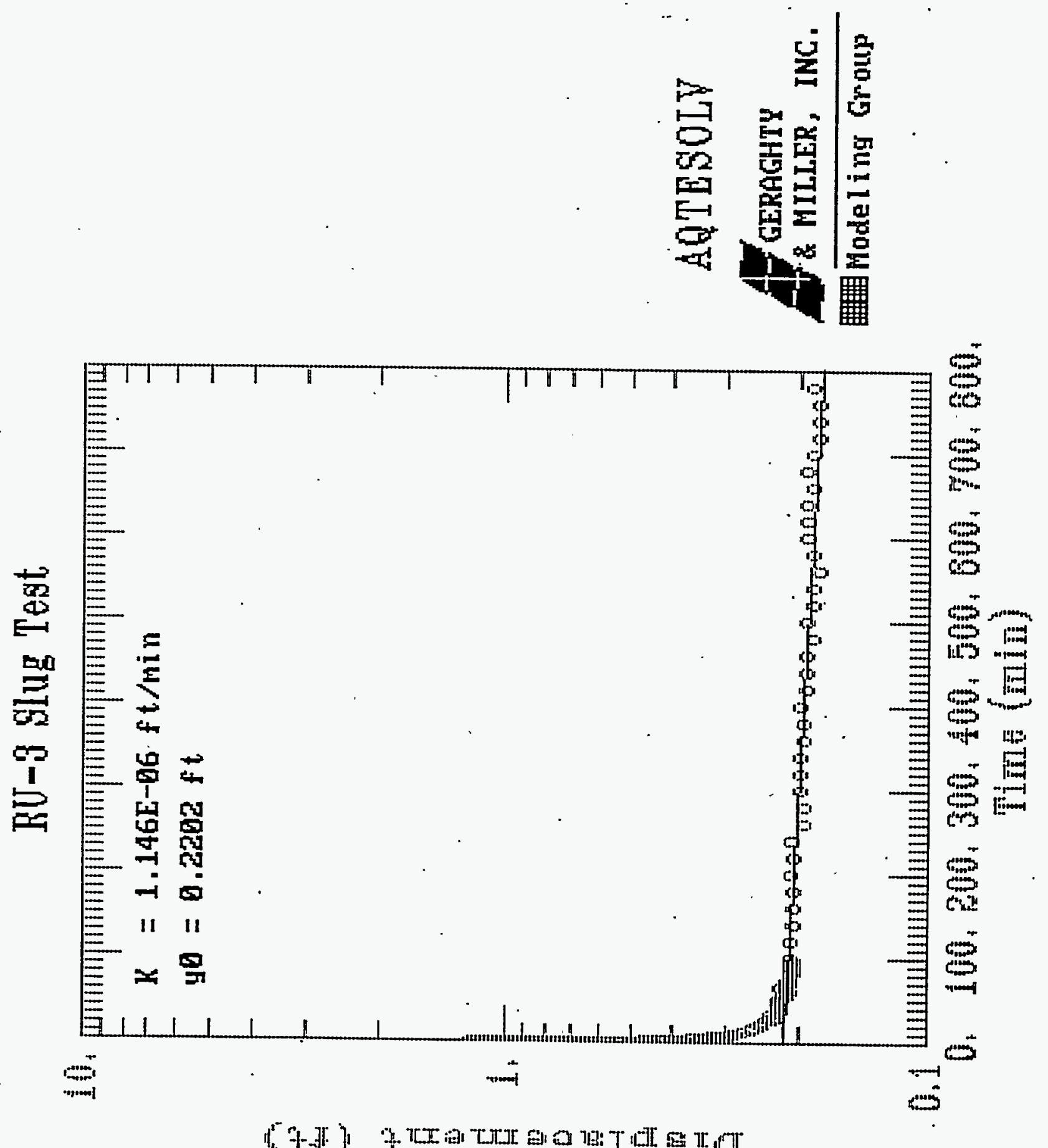


\section{Appendix I}

Risk Assessment 



\section{Table of Contents}

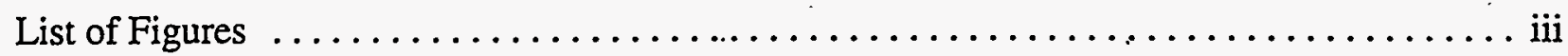

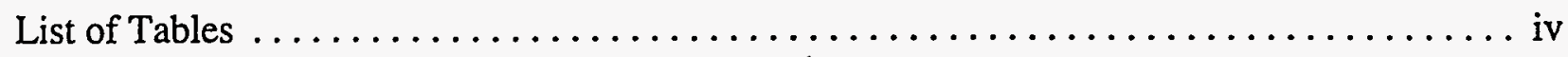

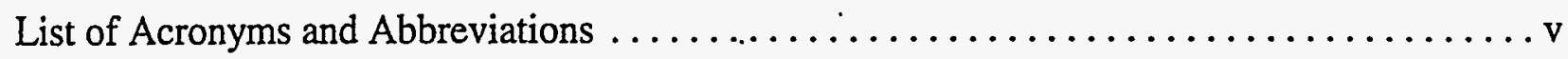

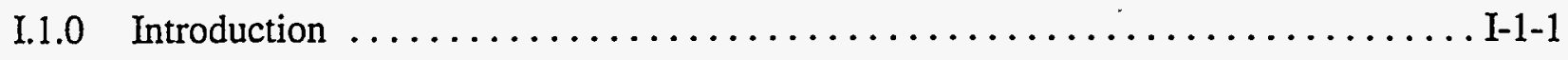

I.2.0 Identification of Constituents of Potential Concern $\ldots \ldots \ldots \ldots \ldots \ldots \ldots \ldots$ I-2-1

I.2.1 Methodology for Selection of Constituents of Potential Concern ......... I-2-1

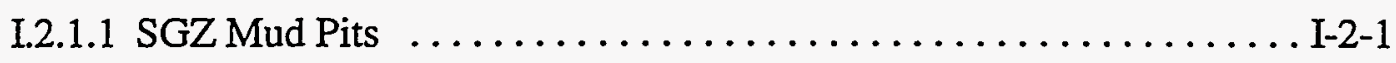

I.2.1.2 Groundwater Downgradient of the Drilling Effluent Pond and

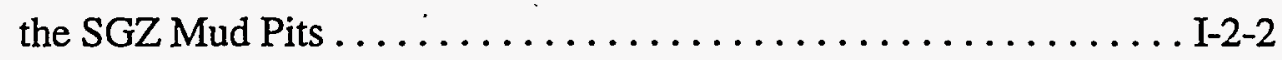

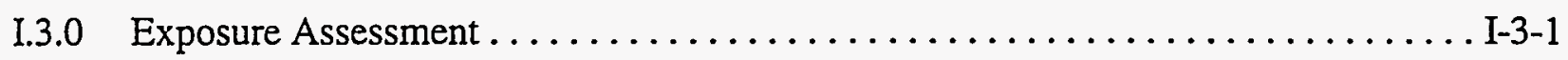

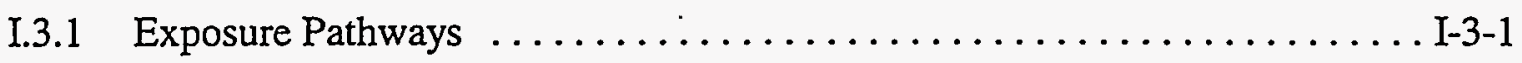

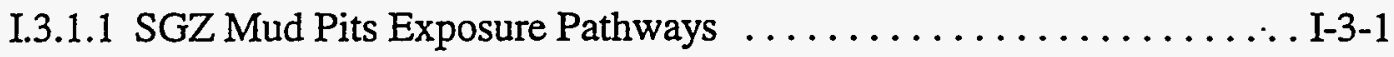

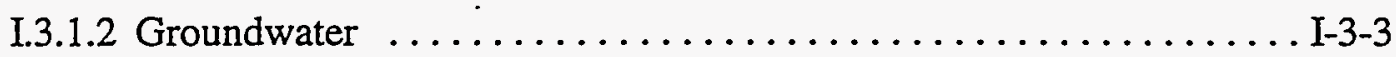

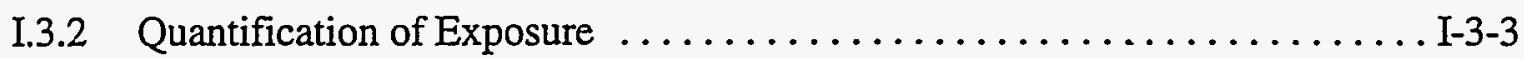

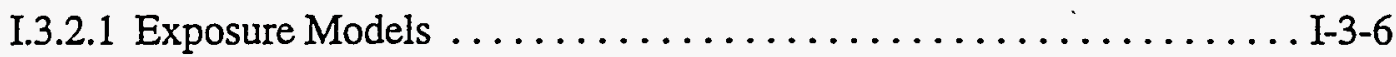

I.3.2.1.1 Ingestion of Soil and Groundwater $\ldots \ldots \ldots \ldots \ldots \ldots$ I-3-7

I.3.2.1.2 Inhalation of Dust $\ldots \ldots \ldots \ldots \ldots \ldots \ldots \ldots \ldots \ldots$ I-3-7

I.3.2.1.3 Inhalation of VOCs while Showering $\ldots \ldots \ldots \ldots \ldots \ldots$ I-3-9

I.3.2.1.4 Dermal Contact Soil and Sediment ............. I-3-10

I.3.2.2 Intakes for Constituents of Potential Concern ............ I-3-11

I.3.2.2.1 Dermal Contact with Groundwater ............ I-3-16

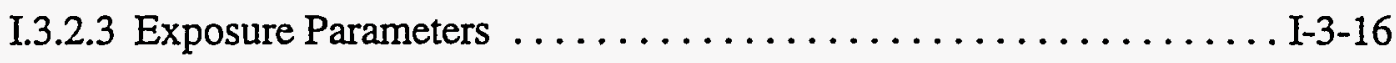

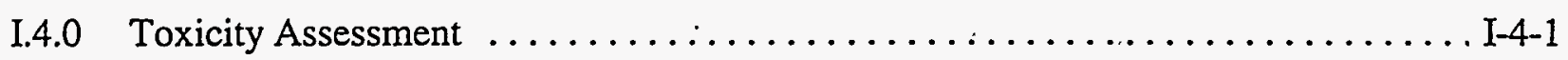

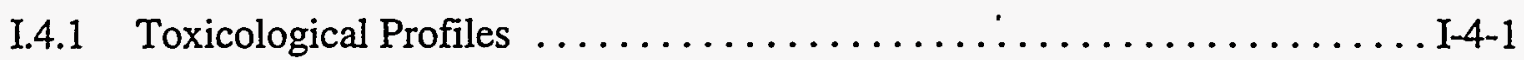

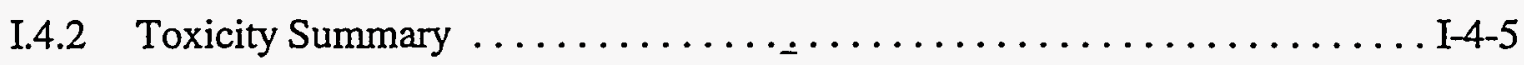


Table of Contents (Continued).

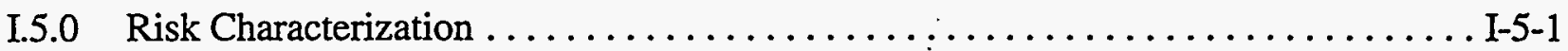

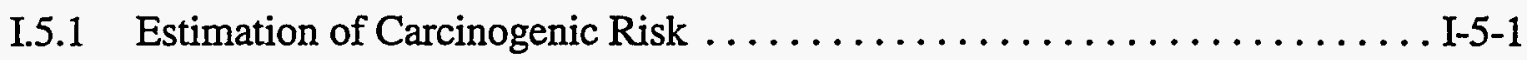

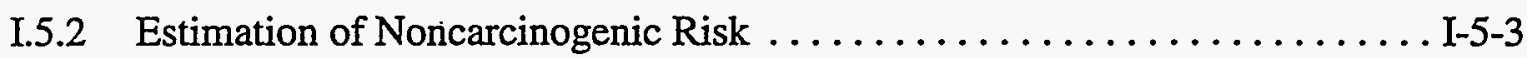

I.5.3 Results of the Human Health Risk Assessment $\ldots \ldots \ldots \ldots \ldots \ldots \ldots \ldots \ldots \ldots \ldots$

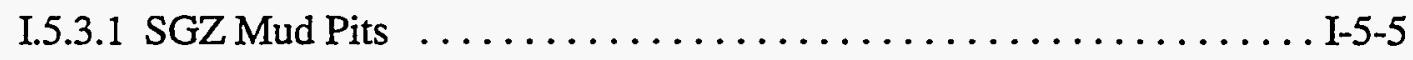

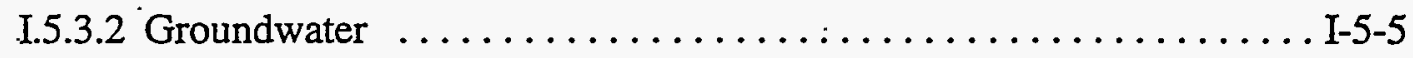

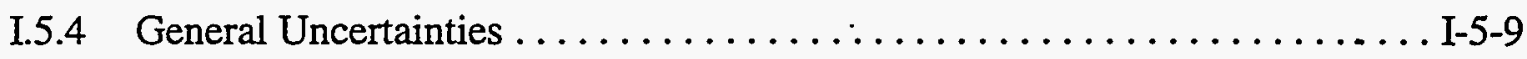

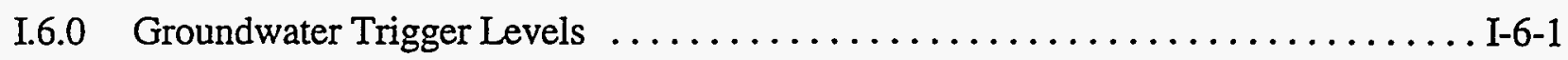

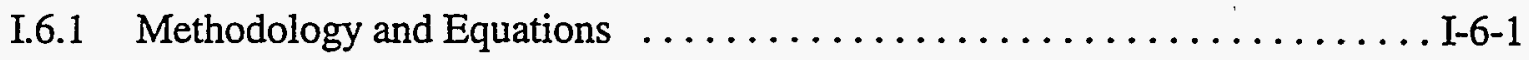

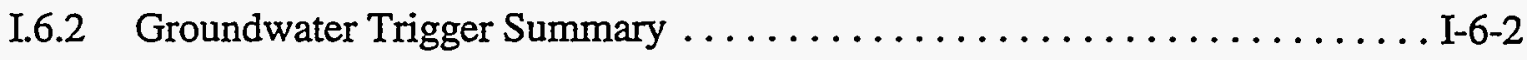

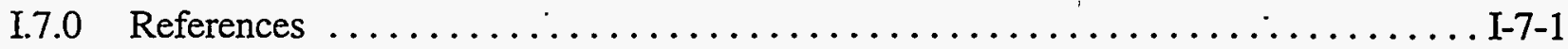




\section{List of Figures}

Number

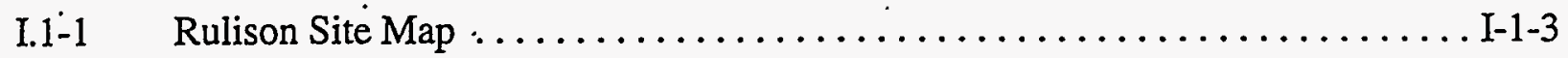

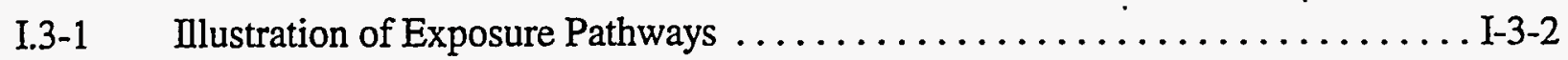

I.3-2 Site Conceptual Model for Future Land Use $\ldots \ldots \ldots \ldots \ldots \ldots \ldots \ldots$ I-3-4 
Number

1.2-1 Constituents of Potential Concern Summary Statistics for Soil at the S.GZ Mud Pits for Rulison, Colorado

I.2-2 Constituents of Potential Concern Summary Data for Groundwater for Rulison, Colorado

I.3-1 Potentially Complete Human Exposure Pathways for Future Land Use at Rulison

I.3-2 Constituent-Specific Input Parameters

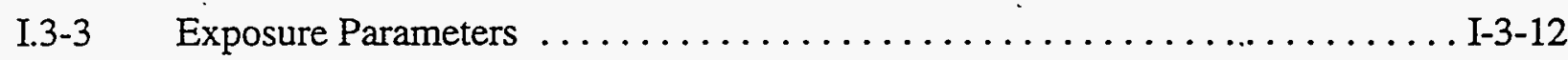

I.3-4 Intake Concentrations for Subsurface Soil at the SGZ Mud Pits of Rulison . . I-3-14

I.3-5 Intake Concentrations for Groundwater in the Vicinity of Rulison ....... I-3-15

I.4-1 Summary of Toxicity Data for COPCs at Rulison, Colorado $\ldots \ldots \ldots \ldots \ldots$ I-4-5

I.5-1 Incremental Lifetime Cancer Risks and Hazard Quotients/Indices for Future Residential Exposure to Subsurface Soil at the SGZ Mud Pits $\mathrm{I}-5-6$

I.5-2 Incremental Lifetime Cancer Risks and Hazard Quotients/Indices for Future Residential Exposure to Groundwater at Rulison $\mathrm{I}-5-7$

I.6-1 Summary of Rulison Groundwater Trigger Levels I-6-3 


\section{List of Acronyms and Abbreviations}

$\begin{array}{ll}\text { AEC } & \text { U.S. Atomic Energy Commission } \\ \text { atm-m }{ }^{3} / \mathrm{mol} & \text { Atmospheres - cubic meter(s) per mole } \\ { }^{\circ} \mathrm{C} & \text { Degree(s) Celsius } \\ \text { CASRN } & \text { Chemical Abstracts Service Registry Number } \\ \mathrm{CFR} & \text { Code of Federal Regulations } \\ \mathrm{cm}^{2} & \text { Centimeter(s) squared } \\ \mathrm{cm}^{2} \mathrm{hr} & \text { Centimeter(s) per hour } \\ \mathrm{COPC} & \text { Constituent of potential concern } \\ \mathrm{CDPHE} & \text { Colorado Department of Public Health and Environment } \\ \mathrm{DTSC} & \text { Department of Toxic Substance Control } \\ \mathrm{EPA} & \text { Environmental Protection Agency } \\ \mathrm{g} & \text { Gram(s) } \\ \mathrm{g} / \mathrm{m}^{2} & \text { Gram(s) per meter(s) squared } \\ \mathrm{HEAST} & \text { Health Effects Assessment Summary Tables } \\ \mathrm{HI} & \text { Hazard index } \\ \mathrm{HT} & \text { Tritium gas } \\ \mathrm{HTO} & \text { Tritium oxide } \\ \mathrm{HQ} & \text { Hazard quotient } \\ \mathrm{hr} / \mathrm{day} & \text { Hour(s) per day } \\ \mathrm{ILCR} & \text { Incremental lifetime cancer risk } \\ \mathrm{IRIS} & \text { Integrated Risk Information System } \\ \mathrm{kg} & \text { Kilogram(s) } \\ \mathrm{kg} / \mathrm{day} & \text { Kilogram(s) per day } \\ \mathrm{kg} / \mathrm{mg} & \text { Kilogram(s) per milligrams } \\ \mathrm{L} / \mathrm{cm}^{3} & \text { Liter(s) per cubic centimeters } \\ \mathrm{L} / \mathrm{day} & \text { Liter(s) per day } \\ \mathrm{L} / \mathrm{min} & \text { Liter(s) per minute } \\ \mathrm{m}^{2} & \text { Square meter(s) } \\ \mathrm{m}^{3} & \text { Cubic meter(s) } \\ \mathrm{m}^{3} / \mathrm{day} & \text { Cubic meter(s) per day } \\ \mathrm{m} \mathrm{m}^{3} / \mathrm{min} & \text { Cubic meter(s) per minute } \\ \mathrm{mg} / \mathrm{cm}{ }^{2} & \text { Milligram(s) per centimeter(s) squared } \\ \mathrm{mg} / \mathrm{day} & \text { Milligram(s) per day } \\ & \end{array}$




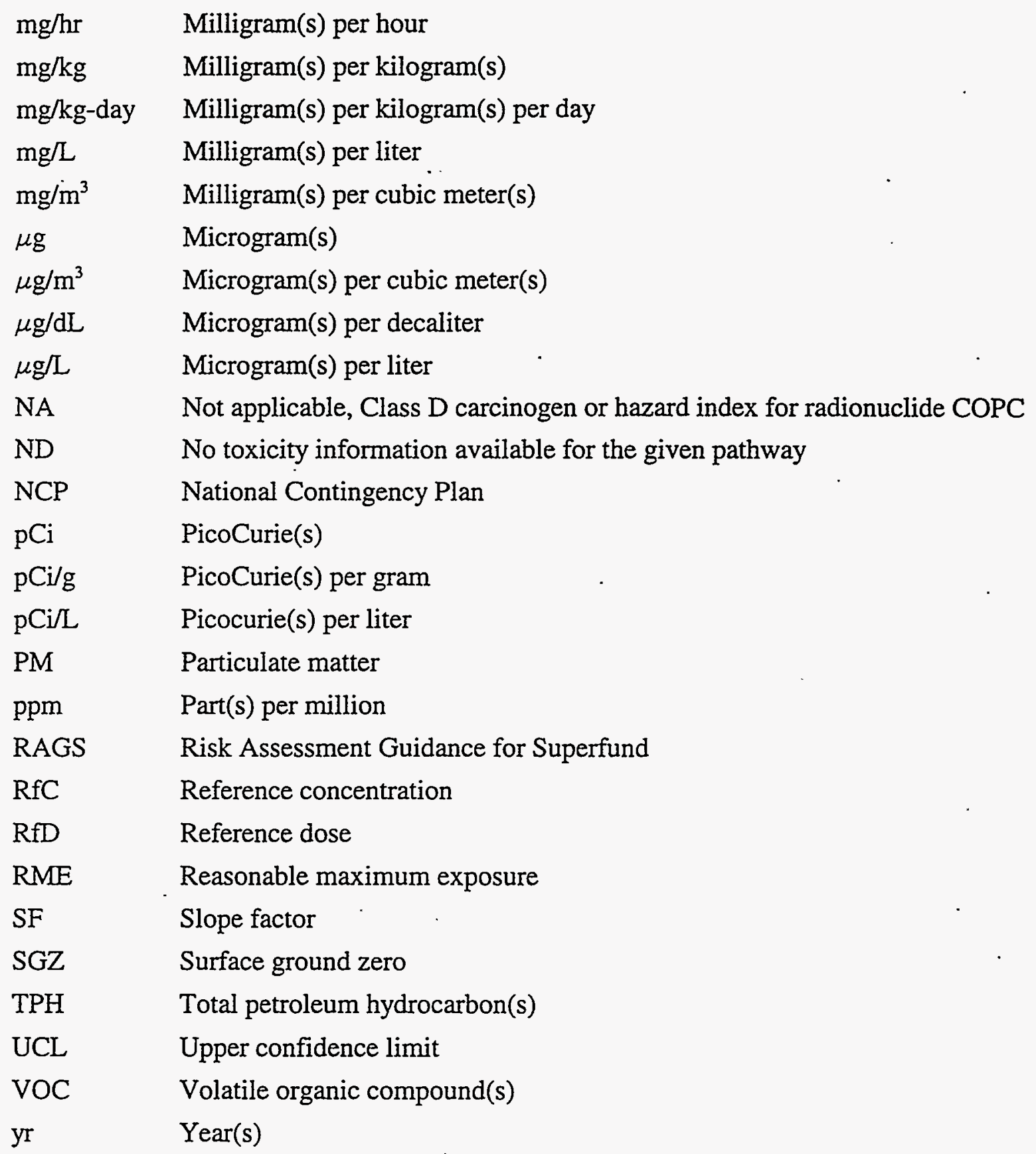

SGZ Surface ground zero

TPH Total petroleum hydrocarbon(s)

UCL Upper confidence limit

VOC Volatile organic compound(s)

yr $\quad$ Year(s) 


\section{I.1.0 Introduction}

The purposes of the Rulison human health risk assessment were to estimate the risk of potential residential exposure to current site conditions and to determine conservative trigger levels for the constituents of potential concern (COPC) which, if exceeded, would indicate a need to further evaluate site monitoring data. This risk assessment was conducted to comply with the conditions set forth by the Colorado Department of Public Health and Environment (CDPHE) for increasing the drilling effluent pond TPH cleanup criterion from 250 to 1,000 milligrams per kilogram $(\mathrm{mg} / \mathrm{kg})$.

The current conditions at the Rulison site indicate two areas of concern: the surface ground zero (SGZ) mud pits and the drilling effluent pond (Figure I.1-1). The SGZ mud pits were backfilled with earth (AEC, 1973), and as described in Section 3.0 of the main body of the report, the drilling effluent pond was cleaned up. However, subsurface soil at both locations is contaminated, and a scenario for this contamination to migrate to and contaminate the groundwater was used to calculate a potential human health risk. This risk assessment was based on an assumption that future land use would involve a residential scenario where human inhabitants would be exposed to contaminants in groundwater from the drilling effluent pond and/or the SGZ mud pits. The risk assessment was also based on.the assumption that residents would excavate contaminated subsurface soil at the SGZ mud pits and redistribute the soil on the ground surface, resulting in a scenario where residents are exposed to the contaminants only through direct contact. These future land use assumptions were developed based on consultation with the CDPHE.

Currently available analytical data for groundwater at the Rulison site show no concentrations of COPCs above the analytical detection limits, with the exception of barium, lead, and xylene. . Therefore, the risks were calculated using the highest measured concentration in any groundwater monitoring well sample exceeding the detection limit or, when a COPC was not detected, its analytical detection limit was used. Trigger levels were calculated based on a risk threshold of either a hazard index of one or a lifetime cancer risk of $1 \times 10^{-6}$.

- The risk assessment was performed in accordance with the "Risk Assessment Guidance for Superfund"(RAGS) (EPA, 1989) and with guidance provided by the U.S. Environmental Protection Agency (EPA). 
The following major elements are included in this appendix: identification of the constituents of potential concern (Section I.2.0), exposure assessment (Section I.3.0), toxicity assessment . (Section I.4.0), risk characterization (Section I.5.0), and trigger levels (Section I.6.0). 


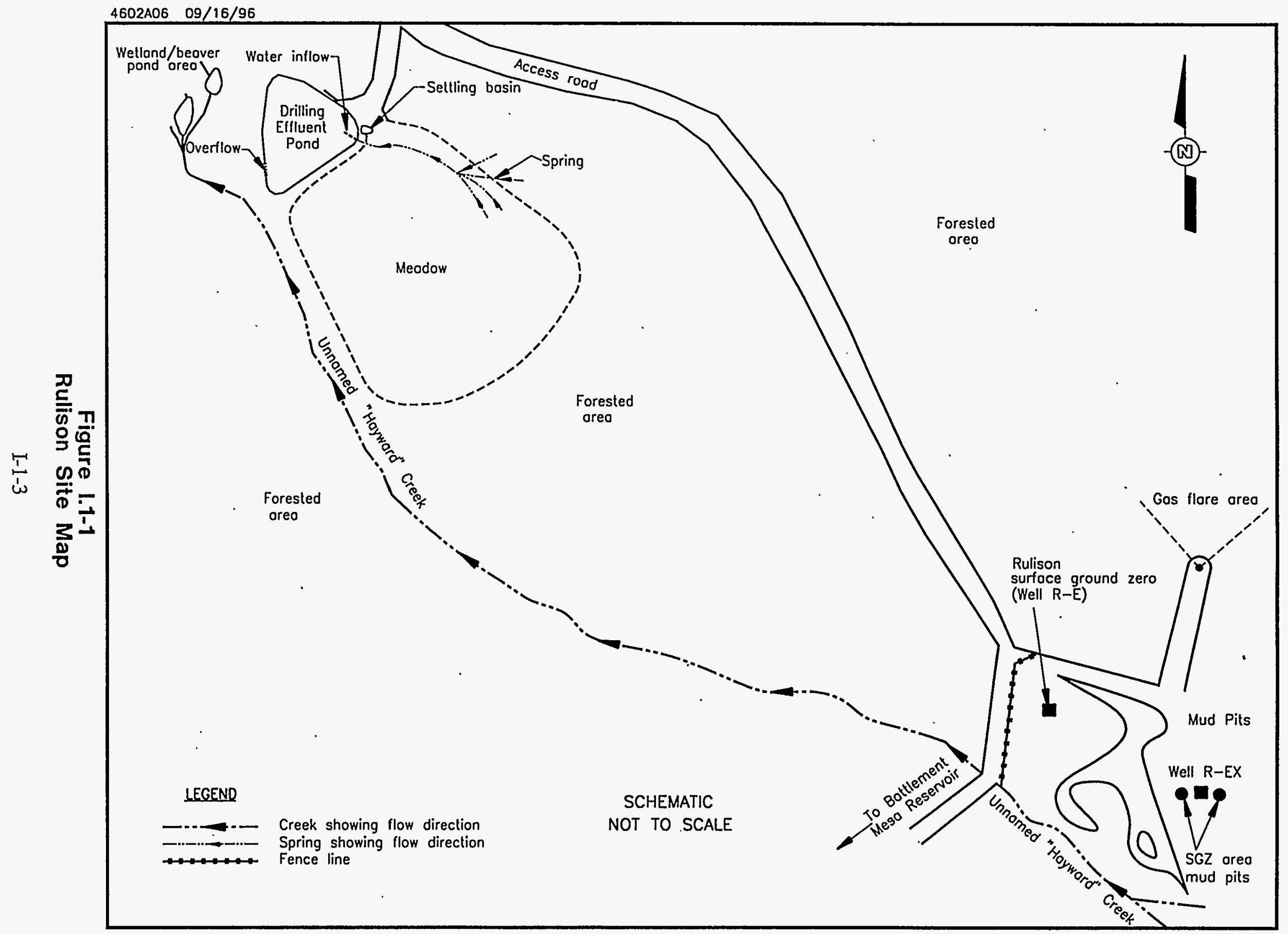





\section{I.2.0 Identification of Constituents of Potential Concern}

The constituents of potential concern for the drilling effluent pond and the SGZ mud pits were selected based on an evaluation of currently available information. This process evaluated historical site information, sample collection and analytical methods, analytical data results of samples collected, and quality of the data. Constituents evaluated in this analysis were selected based on technical judgment of constituents likely to be site-related (see Sections 3.0, 4.0, and 5.0 in the main body of the report).

\subsubsection{Methodology for Selection of Constituents of Potential Concern}

The following sections summarize the analytical information available for each of the areas of concern at Rulison. Included in this summary is a description of the medium sampled, a summary of the levels of COPC detected on site, and the statistical analysis, if any, for each medium.

\subsubsection{SGZ Mud Pits}

Environmental media sampled at and around the SGZ mud pits included soil borings, groundwater samples from two on-site wells, and Hayward Creek sediment, bank soils, and stream water samples.

The analytical data for the SGZ mud pits soil borings are summarized in Section 4.1 .3 of the main body of the report; the COPCs are barium, chromium, lead, benzene, ethylbenzene, toluene, xylene, tritium, and total petroleum hydrocarbons (TPH) as diesel. Using the Excel ${ }^{\circledR}$ statistical software package, the following statistics were calculated for each data set: maximum detected value, minimum detected value, mean, standard deviation, and 95 percent upper confidence limit (UCL) of the mean. One half of the detection limit was used for all non-detects. The statistics for soil/sediment samples from the SGZ mud pits area are summarized in Table I.2-1. The analytical data for all SGZ mud pits samples are presented in Table 4-1 of the main body of the report.

Samples collected for chromium were analyzed for total chromium and did not differentiate between trivalent ( $\mathrm{m}$ ) and hexavalent (VI) chromium. A ratio of 1 part chromium VI for every 6 parts of total chromium was assumed. The remaining chromium was assumed to be all trivalent. 


\subsubsection{Groundwater Downgradient of the Drilling Effluent Pond and the SGZ Mud Pits}

Groundwater is a medium of concern for drilling effluent pond and the SGZ mud pits area. Data are available from the October 1995 quarterly sampling from three groundwater monitoring wells for the drilling effluent pond and from two wells for the SGZ mud pits (Figure 1.1-1) (see Section 5.0 of the main body of the report for a detailed description of the monitoring wells). The COPCs for groundwater were assumed to be the same as those detected in the SGZ mud pits. With the exception of tritium, these also were the COPCs for the pond cleanup. No statistics were calculated on the groundwater analytical data. The data from groundwater monitoring wells near the drilling effluent pond and the SGZ mudpits are summarized in Table I.2-2.

Groundwater analytical results for all monitoring wells are presented in Table 5-1 of the main body of the report.

Table 1.2-1

Constituents of Potential Concern Summary Statistics for Soil at the SGZ Mud Pits for Rulison, Colorado

\begin{tabular}{|c|c|c|c|c|c|}
\hline \multicolumn{6}{|c|}{ Radiological } \\
\hline Radionuclide & $\underset{(p C i / g)}{\operatorname{Minimum}}$ & $\underset{(\mathrm{pCi} / \mathrm{g})}{\operatorname{Maximum}}$ & $\begin{array}{r}\text { Mean } \\
(\mathrm{pCi} / \mathrm{g})\end{array}$ & $\begin{array}{l}\text { Standard } \\
\text { Deviation }\end{array}$ & $\begin{array}{l}95 \% \text { UCL }^{b} \text { of } \\
\text { the Mean } \\
\text { (pCi/g) }\end{array}$ \\
\hline Tritium & 0.015 & 0.98 & 0.123 & 0.253 & 0.24 \\
\hline \multicolumn{6}{|c|}{ Chemical } \\
\hline Chemicals & $\underset{(\mathrm{mg} / \mathrm{kg})}{\operatorname{Minimum}^{\mathrm{a}}}$ & $\underset{(\mathrm{mg} / \mathrm{kg})}{\text { Maximum }}$ & $\begin{array}{c}\text { Mean } \\
(\mathrm{mg} / \mathrm{kg})\end{array}$ & $\begin{array}{l}\text { Standard } \\
\text { Deviation }\end{array}$ & $\begin{array}{c}95 \% \text { UCL of } \\
\text { the Mean } \\
\text { (mg/kg) }\end{array}$ \\
\hline Barium & 113 & 3990 & 557 & .937 & 1003 \\
\hline Benzene & 0.0025 & 0.29 & 0.019 & 0.068 & 0.051 \\
\hline Chromium & 13.2 & 112 & 37.7 & 25.1 & 49.7 \\
\hline Ethylbenzene & 0.0025 & 1.4 & 0.087 & 0.328 & 0.238 \\
\hline Lead & 6.7 & 119 & 30.3 & 34.9 & 46.91 \\
\hline Toluene & 0.0025 & 0.12 & 0.014 & 0.0030 & 0.028 \\
\hline TPH as Diesel & 12 & 4700 & 934 & 973 & 1633 \\
\hline Xylene & 0.0025 & 23.0 & 1.33 & 5.41 & 3.83 \\
\hline
\end{tabular}

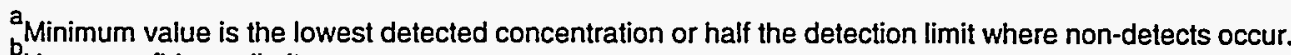

Upper confidence limit

Samples collected on October 6-8, 1995
} 
Table 1.2-2

\section{Constituents of Potential Concern Summary Data for Groundwater for Rulison, Colorado}

\begin{tabular}{|c|c|c|c|}
\hline \multicolumn{4}{|c|}{ Radiological } \\
\hline Radionuclide & $\begin{array}{l}\text { Minimum } \\
(\mathrm{pCi} / \mathrm{L})\end{array}$ & $\begin{array}{l}\text { Maximum } \\
(\mathrm{pCi} / \mathrm{L})\end{array}$ & $\begin{array}{c}\text { Concentration Used in } \\
\text { Risk Assessment } \\
(\mathrm{pCi} / \mathrm{L})\end{array}$ \\
\hline Tritium & $254 U^{b}$ & $254 U^{b}$ & $254 U^{b}$ \\
\hline \multicolumn{4}{|c|}{ Chemical } \\
\hline Chemicals & ${ }_{,}^{\text {Minimum }^{a}}$ & $\begin{array}{c}\text { Maximum } \\
(\mathrm{mg} / \mathrm{L})\end{array}$ & $\begin{array}{c}\text { Concentration Used in } \\
\text { Risk Assessment } \\
\text { (mg/L) }\end{array}$ \\
\hline Barium & $0.0682^{c}$ & $0.258^{d}$ & 0.258 \\
\hline Benzene & $0.001 \mathrm{U}^{\mathrm{e}}$ & $0.001 \mathrm{U}$ & $\cdot 0.001 \mathrm{U}$ \\
\hline Chromium & $0.0027 \mathrm{U}$ & $0.02 \mathrm{U}$ & $0.02 \mathrm{U}$ \\
\hline Ethylbenzene & $0.001 \mathrm{U}$ & $0.001 \mathrm{U}$ & $0.001 \mathrm{U}$ \\
\hline Lead & $0.0008 \mathrm{U}$ & $0.0051^{d}$ & 0.0051 \\
\hline Toluene & $0.001 \mathrm{U}$ & $0.001 \mathrm{U}$ & $0.001 \mathrm{U}$ \\
\hline TPH as Diesel & $0.5 \mathrm{U}$ & $0.5 \mathrm{U}$ & $0.5 \mathrm{U}$ \\
\hline Xylene & $0.001 \mathrm{U}$ & $0.0015^{f}$ & 0.0015 \\
\hline
\end{tabular}

\footnotetext{
${ }^{a}$ Minimum value is the lowest detected concentration or the detection limit where non-detects occur.

Sampling results for tritium are available only from the SGZ mud pits area monitoring wells.

Sample is from SGZ mud pits area monitoring well RU-01

Sample is from drilling effluent pond monitoring well RU-08

Compound was analyzed but not detected above the specified detection limits in any of the monitoring well samples.

Sample is from SGZ mud pits area monitoring well RU-02

Samples collected on October 23-27, 1995
} 



\section{I.3.0 Exposure Assessment}

The exposure assessment estimates the type and magnitude of exposure to humans from the constituents of potential concern. The exposure pathways and calculations of chemical intakes are outlined below for both of the Rulison areas.

\subsubsection{Exposure Pathways}

For exposure and potential risks to occur, complete exposure pathways must exist. A complete pathway requires the following elements (EPA, 1989):

- A source and mechanism for release of contamination

- A transport or retention medium

- A point of potential human contact (exposure point) with the contaminated medium

- An exposure route at the exposure point.

If any one of these elements is missing, the pathway is not considered complete. Figure I.3-1 is an illustration of how these elements are combined into a complete pathway.

\section{I.3.1.1 SGZ Mud Pits Exposure Pathways}

Contamination sources are addressed in Section I.2.0. As discussed above, the only COPCs at the SGZ mud pits occur in subsurface soils. Therefore, subsurface soil is both the transport and retention medium.

Exposure points are locations of human contact with contaminated media. Exposure points consider human activity patterns and the location of potentially exposed individuals relative to the location of contaminated media. For this assessment, contact with potentially contaminated media takes place as a result of residential exposures only. To maintain the conservative methodology of RAGS (EPA, 1989), the contact point for soil contamination with all exposure scenarios is located at the contaminant source.

The following three exposure routes were examined:

- Ingestion

- Inhalation of dust

- Dermal contact 


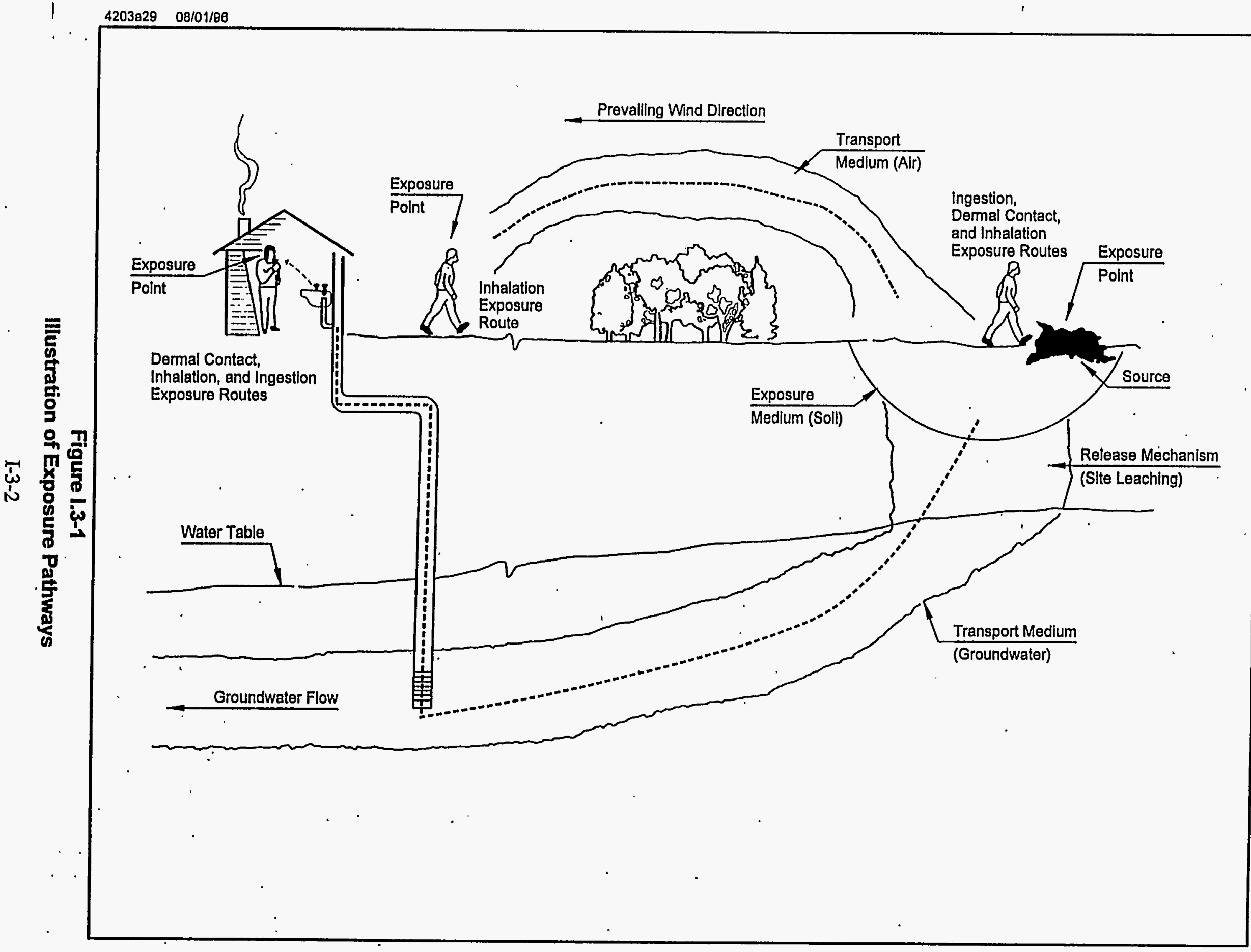


Because the only contamination source is subsurface soil, there are no current feasible pathways, and there is no exposure point (point of human contact) for subsurface soil under current conditions. The only potential complete exposure pathway is a hypothetical future residential exposure to subsurface soil due to the removal of the surface soil. Figure 1.3-2 illustrates the site conceptual model for Rulison.

Table 1.3-1 lists the complete human exposure pathways for future land use. This table indicates which pathways have been selected for risk characterization and presents the rationale for inclusion or exclusion of each pathway.

\subsubsection{Groundwater}

As discussed above, the medium of concern at the drilling effluent pond is groundwater. This scenario is also used to represent the groundwater medium risk evaluation for the SGZ mud pits area. The only potential exposure point currently present is a spring used by the drilling effluent pond land owner. However, this spring is thought to be cross-gradient from the pond. There currently are no domestic groundwater wells in the area. Because of this, a future residential receptor is the only potential exposure to population at Rulison (Table I.3-1). The following three exposure routes were considered:

- Ingestion

- Inhalation of VOCs while showering

- Dermal contact while showering.

\subsubsection{Quantification of Exposure}

This section describes the estimation of exposures for the constituents of potential concern that may come in contact with human receptors. The process involves the following:

- Identification of applicable human exposure models and input parameters

- Determination of the concentration of each constituent in environmental media at the point of human exposure

- Estimation of human intakes.

For each potentially complete future exposure pathway identified in Section I.3.1, a reasonable maximum exposure (RME) scenario has been developed. The RME is the highest exposure that is reasonably expected to occur at a site (EPA, 1989). The intent of the RME, as defined by the 


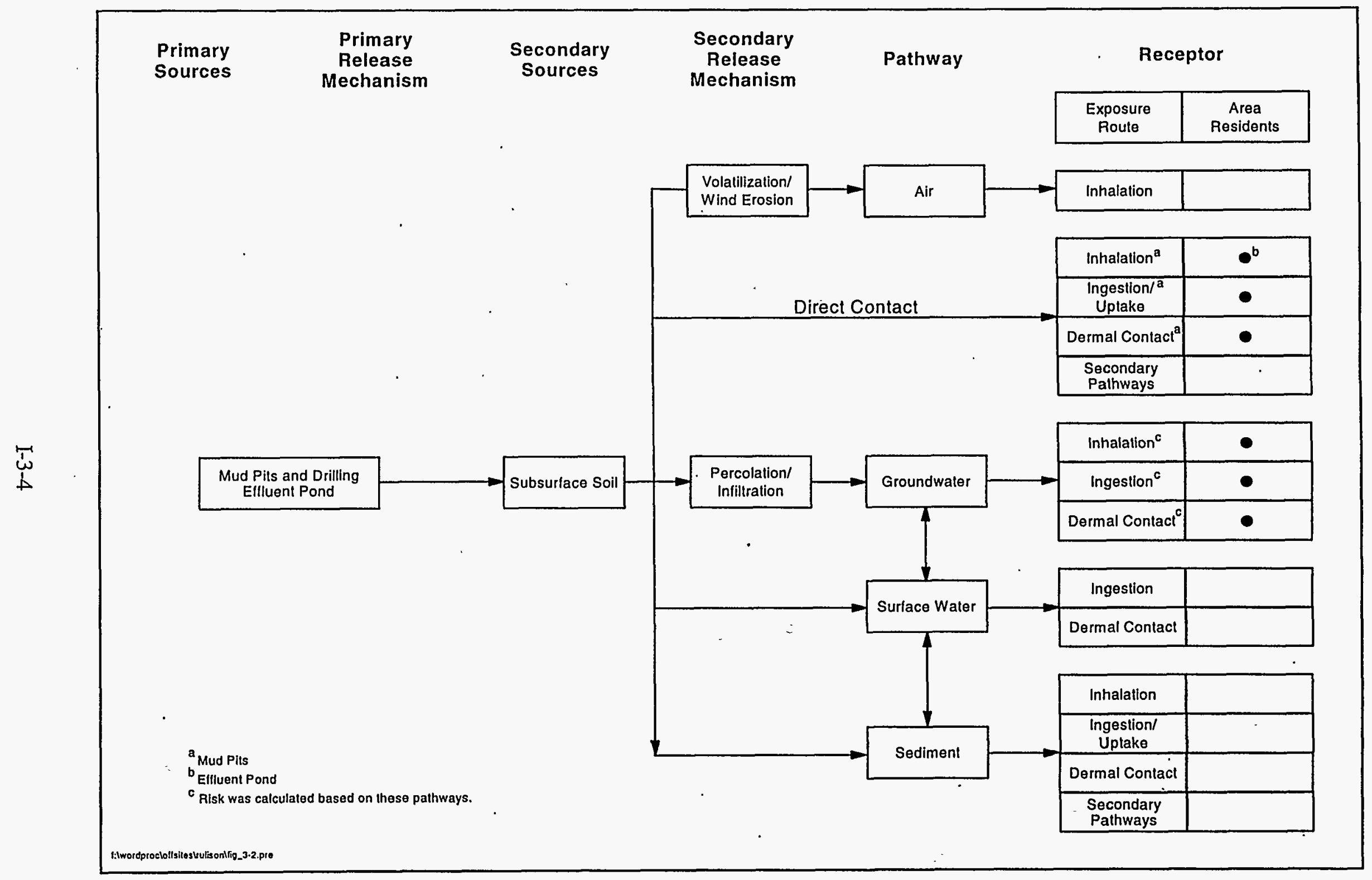

Figure 1.3-2

Site Conceptual Model for Future Land Use 
Table 1.3-1

Potentially Complete Human Exposure Pathways for Future Land Use at Rulison

\begin{tabular}{|c|c|c|c|c|}
\hline $\begin{array}{l}\text { Environmental } \\
\text { Medium }\end{array}$ & Exposure Route & $\begin{array}{l}\text { Potentially Exposed } \\
\text { Population }\end{array}$ & $\begin{array}{l}\text { Pathway } \\
\text { Selected for } \\
\text { Evaluation }\end{array}$ & Reason for Selection or Exclusion \\
\hline Surface Soil & $\begin{array}{l}\text { Inhalation } \\
\text { Ingestion } \\
\text { Dermal Contact }\end{array}$ & $\begin{array}{l}\text { Residents } \\
\text { Trespassers } \\
\text { Workers }\end{array}$ & No & No surface contamination was found. \\
\hline Surface Water & $\begin{array}{l}\text { Inhalation } \\
\text { Ingestion } \\
\text { Dermal Contact }\end{array}$ & $\begin{array}{l}\text { Residents } \\
\text { Trespassers } \\
\text { Workers }\end{array}$ & No & No surface water contamination was found. \\
\hline $\mathrm{Air}^{\mathrm{a}}$ & Inhalation & $\begin{array}{c}\text { Residents } \\
\text { Trespassers } \\
\text { Workers } \\
\end{array}$ & No & No air sampling occurred. \\
\hline Groundwater & $\begin{array}{l}\text { Inhalation } \\
\text { Ingestion } \\
\text { Dermal Contact }\end{array}$ & Residents & Yes & $\begin{array}{l}\text { Potential transport of COPCs from subsurface } \\
\text { soil to groundwater was considered. Current } \\
\text { groundwater analytical data were used in the } \\
\text { calculation of risk. The groundwater pathway is } \\
\text { considered future due to a lack of current. } \\
\text { residential wells in the potentially affected area. }\end{array}$ \\
\hline Groundwater & $\begin{array}{l}\text { Inhalation } \\
\text { Ingestion } \\
\text { Dermal Contact }\end{array}$ & $\begin{array}{c}\text { Trespassers } \\
\text { Workers }\end{array}$ & No & $\begin{array}{l}\text { Consideration of a residential receptor is more } \\
\text { conservative. No long-term occupational } \\
\text { activities are planned at the site. }\end{array}$ \\
\hline Subsurface Soil & $\begin{array}{l}\text { Inhalation } \\
\text { Ingestion } \\
\text { Dermal Contact }\end{array}$ & Residents & Yes & $\begin{array}{l}\text { Direct or indirect exposure to subsurface soil at } \\
\text { depth of contamination is improbable (i.e., no } \\
\text { complete exposure pathway exists). However, } \\
\text { upon removal of surface soil, a residential } \\
\text { receptor is the most likely and conservative. }\end{array}$ \\
\hline Subsurface Soil & $\begin{array}{l}\text { Inhalation } \\
\text { Ingestion } \\
\text { Dermal Contact }\end{array}$ & $\begin{array}{l}\text { Workers } \\
\text { Trespassers }\end{array}$ & No & $\begin{array}{l}\text { Consideration of a residential receptor is more } \\
\text { conservative. No long-term occupational } \\
\text { activities are planned at the site. }\end{array}$ \\
\hline
\end{tabular}

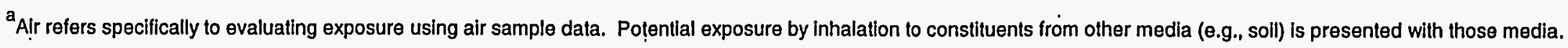


U.S. Environmental Protection Agency (EPA), is to estimate a conservative exposure case (i.e., well above the average case) that is still within the possible range of exposures. The RME is both protective and reasonable, but not the worst possible case (EPA, 1991a).

\subsubsection{Exposure Models}

The primary source for the exposure models used in this baseline risk assessment is RAGS (EPA, 1989). Shown below is the generalized equation for calculating chemical intakes:

$$
I=C \frac{C R \times E F D}{B W \times A T}
$$

where

I = Intake; the amount of chemical at the exchange boundary (milligrams [mg] per kg body weight-day).

$\mathrm{C}=$ Chemical concentration at the exposure point; the concentration contacted over the exposure period (e.g., $\mathrm{mg}$ per liter [L] water or $\mathrm{mg} / \mathrm{kg}$ soil).

$\mathrm{CR}=$ Contact rate; the amount of contaminated medium contacted per unit time or event (e.g., $\mathrm{mg}$ per day soil ingestion rate or $\mathrm{m}^{3}$ per hour air inhalation rate).

$\mathrm{EFD}=$ Exposure frequency and duration; describes how often and how long exposure occurs. Often calculated using two terms (EF times ED).

$\mathrm{EF}=$ Exposure frequency (days/year).

$E D=$ Exposure duration (years).

$\mathrm{BW}=$ Body weight; the average body weight over the exposure period $(\mathrm{kg})$.

$\mathrm{AT}=$ Averaging time; period over which exposure is averaged (days).

Pathway-specific exposure models are summarized in the following sections. 


\subsection{Ingestion of Soil and Groundwater}

For estimating intake from ingestion of groundwater and soil the following equation applies.

$$
\text { Intake }=\frac{C_{i} \times E F \times F}{A T} \times\left[\left(\frac{I R \times E D}{B W}\right)_{c h i l d}+\left(\frac{I R \times E D}{B W}\right)_{a d u l t}\right]
$$

where

$$
\begin{aligned}
& \text { Intake }=\text { Intake of chemical through ingestion of medium (mg/kg-day) } \\
& C_{i} \quad=\text { Chemical concentration in medium } \mathrm{i}(\mathrm{mg} / \mathrm{kg} \mathrm{or} \mathrm{mg} / \mathrm{L}) \\
& \mathbb{R} \quad=\text { Ingestion rate for medium i and receptor }(\mathrm{kg} / \text { day or } \mathrm{L} / \text { day) } \\
& \mathrm{F} \quad=\text { Fraction of ingested medium from contaminated source (unitless) }
\end{aligned}
$$

EF, ED, BW, and AT are defined in Section I.3.2.1.

For the soil pathway, the child is considered to be exposed for 6 of the 30 years; this is conservative because children ingest more dirt than adults when compared on the basis of body weight. For the groundwater pathway, the adult is modeled for the 30 years; this is conservative because water ingestion is proportional to body weight.

\subsection{Inhalation of Dust}

For estimating respirable particulate emission from wind erosion, assuming an unlimited reservoir, the equation is (EPA, 1985)

$$
E_{10}=0.036(1-V)\left(\frac{[u]}{u_{t}}\right)^{3} f(x)
$$

where

$$
\begin{aligned}
& \mathrm{E}_{10}=\mathrm{PM}_{10} \text { emission factor (grams }[\mathrm{g}] / \mathrm{m}^{2} \text {-hour }[\mathrm{hr}] \text { ) } \\
& \mathrm{V} \quad=\text { Fraction of contaminated surface vegetative cover (unitless, assumed to be 1.0) } \\
& {[\mathrm{u}] \quad=\text { Mean annual wind speed }(\mathrm{m} / \mathrm{second}[\mathrm{sec}], 3.2 \mathrm{~m} / \mathrm{sec})}
\end{aligned}
$$


$u_{\mathrm{t}} \quad=$ The threshold value of wind speed at $7 \mathrm{~m}(\mathrm{~m} / \mathrm{sec})$

$\mathrm{F}(\mathrm{x})=$ Function plotted in EPA, $1985[\mathrm{~F}(\mathrm{x})=1.5]$ where $\mathrm{x}=0.886 \mathrm{u}_{\mathrm{t}} /[\mathrm{u}]$.

Once the $\mathrm{PM}_{10}$ emission factor is calculated, the emission rates for the individual constituents of potential concern were calculated according to the following:

$$
R_{10}=\alpha \times E_{10} \times A \times C
$$

where

$$
\begin{aligned}
& \mathrm{R}_{10}=\text { Emission rate of contaminant as } \mathrm{PM}_{10}(\mathrm{mg} / \mathrm{hr}) \\
& \alpha \quad=\text { Chemical concentration }(\mathrm{mg} / \mathrm{kg}) \\
& E_{10} \quad=\mathrm{PM}_{10} \text { emission factor }\left(\mathrm{g} / \mathrm{m}^{2}-\mathrm{hr}\right) \\
& \mathrm{A} \quad=\text { Site areas }\left(\mathrm{m}^{2}, \text { assumed to be } 1,000 \mathrm{~m}^{2}\right) \\
& C \quad=\text { Conversion factor for } \mathrm{kg} \text { to } \mathrm{g} 10^{-3} .
\end{aligned}
$$

Once the dust concentration in the air has been calculated for each COPC, the constituent intake is

$$
\text { Intake }=\frac{C_{i} \times B A \times I R \times E T \times E F \times E D}{B W \times A T}
$$

where

$\mathrm{C}_{\mathrm{i}}=$ Chemical-specific air concentration (mg per cubic meter $\left[\mathrm{m}^{3}\right]$ )

$\mathrm{BA}=$ Bioavailability factor (unitless)

$\mathbb{R}=$ Inhalation rate $\left(\mathrm{m}^{3} /\right.$ event, typically $\left.\mathrm{m}^{3} / \mathrm{hr}\right)$

ET = Exposure time (hr/day)

$\mathrm{EF}, \mathrm{ED}, \mathrm{BW}$, and $\mathrm{AT}$ are defined in Section I.3.2.1. 


\section{I.3.2.1.3 Inhalation of VOCs while Showering}

This section presents the methodology for estimating vapor phase concentrations in bathroom air as a result of showering. This model uses experimental results for trichloroethene to estimate the release of other volatile organic compounds by comparing their Henry's Law constants (IT, 1992).

The average concentration of a volatile compound in the shower air over a period of $t_{s}$ minutes is

$$
C_{s}=C_{i n f a} x\left[1+\frac{1}{k t_{s}}\left(\exp ^{-k t_{s}}-1\right)\right]
$$

where

$\mathrm{C}_{\mathrm{s}}=$ Average concentration of a volatile compound in the shower air over a duration of $\mathrm{t}_{\mathrm{s}}$ minutes $\left(\mathrm{mg} / \mathrm{m}^{3}\right)$

$\mathrm{C}_{\text {infa }} \cdot=$ Asymptotic concentration in air if shower ran for a long time (much longer than 5 minutes) $\left(\mathrm{mg} / \mathrm{m}^{3}\right)$, calculated below:

$$
C_{\text {infa }}=\frac{E \times F_{w} \times C_{t}}{F_{a}}
$$

$\mathrm{t}_{\mathrm{s}} \quad=$ Time in shower (minutes $\left.[\mathrm{min}]\right)$

$\mathrm{k}=$ Rate constant for exponential function (1/min), $\mathrm{k}=\mathrm{F}_{\mathrm{a}} / \mathrm{N}_{\mathrm{b}}$

$\mathrm{E}=$ Efficiency of release of a compound from water to air (unitless), defined below; $0 \leq \mathrm{E} \leq 1$; if $\mathrm{E}$ has a calculated value greater than 1, then $\mathrm{E}$ must be set equal to 1 :

$$
E=\frac{E_{T C E} \times H}{H_{T C E}}
$$

$\mathrm{F}_{\mathrm{w}} \quad=$ Flow rate of water in shower $(\mathrm{L} / \mathrm{min})$

$C_{\mathfrak{l}}=$ Concentration of organic compound in shower water $(\mathrm{mg} / \mathrm{L})$

$\mathrm{F}_{\mathrm{a}} \quad=$ Flow rate of air in shower $\left(\mathrm{m}^{3} / \mathrm{min}\right)$ 
$\mathrm{V}_{\mathrm{b}}=$ Volume of bathroom $\left(\mathrm{m}^{3}\right)$

$\mathrm{E}_{\mathrm{TCE}}=$ Efficiency of release of trichloroethene from water to air (unitless)

$\mathrm{H}=$ Henry's Law constant for an organic compound $\left(\mathrm{m}^{3}-\mathrm{atm} / \mathrm{mol}\right)($ see Table $1.3-2)$

$\mathrm{H}_{\mathrm{TCE}}=$ Henry's Law constant for trichloroethene $\left(\mathrm{m}^{3}\right.$-atm/mol).

Once the VOC air concentration has been calculated, the chemical intake while showering can be calculated using the intake equation in the previous section.

\section{I.3.2.1.4 Dermal Contact Soil and Sediment}

The following is the intake equation for dermal absorption of chemicals due to contact from soil or sediment:

$$
A D=\frac{C_{i} \times \times A F \times A B S \times C F}{A T} \times\left[\left(\frac{S A \times E F \times E D}{B W}\right)_{\text {adult }}+\left(\frac{S A \times E F \times E D}{B W}\right)_{\text {child }}\right]
$$

where
$\mathrm{AD}=$ Absorbed dose $(\mathrm{mg} / \mathrm{kg}$-day)
$\mathrm{C}_{\mathrm{i}} \quad=$ Chemical concentration in medium $\mathrm{i}(\mathrm{mg} / \mathrm{kg})$
$\mathrm{SA}=$ Skin surface area available for contact (square centimeters $\left[\mathrm{cm}^{2} /\right.$ event])
$\mathrm{AF}=$ Soil-to-skin adherence factor $\left(\mathrm{mg} / \mathrm{cm}^{2}\right)$
ABS = Skin absorption factor (unitless) (see Table I.3-2)
$\mathrm{CF}=$ Conversion factor $\left(10^{-6} \mathrm{~kg} / \mathrm{mg}\right)$
$\mathrm{EF} \quad=$ Exposure frequency (events/yr)
$\mathrm{ED}, \mathrm{BW}$, and AT are defined in Section I.3.2.1. 
Table 1.3-2

Constituent-Specific Input Parameters

\begin{tabular}{|l|c|c|c||}
\hline \multicolumn{1}{|c|}{ Constituent } & $\begin{array}{c}\text { Absorption } \\
\text { Fraction }\end{array}$ & $\begin{array}{c}\text { Dermal } \\
\text { Permeability } \\
\text { Constant (cm/hr) }\end{array}$ & $\begin{array}{c}\text { Henry's Law Constant } \\
\text { (atm-m }^{3} / \mathrm{mol}^{\mathrm{b}}\end{array}$ \\
\hline \hline Barium & None & $1.0 \mathrm{E}-03$ & None \\
\hline Benzene & 0.1 & $2.1 \mathrm{E}-02$ & 0.00543 \\
\hline Chromium & None & $1.0 \mathrm{E}-03$ & None \\
\hline Ethylbenzene & 0.1 & $7.4 \mathrm{E}-02$ & 0.00844 \\
\hline Lead & None & $1.0 \mathrm{E}-03$ & None \\
\hline Toluene & 0.1 & $4.5 \mathrm{E}-02$ & 0.00594 \\
\hline TPH as Diesel & 0.1 & $2.1 \mathrm{E}-02$ & None \\
\hline Tritium & 0.1 & $1.6 \mathrm{E}-04$ & 0.001 \\
\hline Xylenes & 0.1 & $8.0 \mathrm{E}-02$ & 0.0068 \\
\hline
\end{tabular}

a EPA, 1992

EPA, 1986

The exposed population and exposure-related parameters are summarized in Table I.3-3. All values shown in the table apply to the RME scenario. The exposure parameters have been taken from EPA guidance and are based on best professional judgment using site-specific information, where available. Upper-bound values are generally 90 th or 95 th percentile values, depending on the data available for each parameter. A combination of upper-bound and average exposure parameters were used to estimate the RME for each scenario.

Most of the RME input parameters are from current EPA guidance. The only exception is the exposure frequency for both the soil and groundwater pathways. A value of 180 days/year was assumed due to regional snow cover and corresponding site access limitations.

\subsubsection{Intakes for Constituents of Potential Concern}

Noncarcinogenic and carcinogenic intakes of subsurface soil COPCs at the SGZ mud pits are tabulated in Table 1.3-4, and intakes for groundwater COPCs are tabulated in Table 1.3-5. Intakes are expressed in units of milligrams of individual constituent per kilogram of receptor per day. 
Table 1.3-3

Exposure Parameters

(Page 1 of 2)

\begin{tabular}{|c|c|c|c|}
\hline Parameter & Value & Units & Reference/Rationale \\
\hline \multicolumn{4}{|c|}{ RESIDENTIAL INGESTION OF SOIL } \\
\hline $\begin{array}{l}\text { Ingestion Rate } \\
\text { Adult } \\
\text { Child }\end{array}$ & $\begin{array}{l}100 \\
200 \\
\end{array}$ & mg/day & EPA, $1991 a$ \\
\hline Fraction Ingested & 1 & unitless & Assumes all of soil intake from sile \\
\hline Exposure Frequency & 180 & day/year & Value assumed, due to snow cover \\
\hline $\begin{array}{l}\text { Exposure Duration } \\
\text { Adult } \\
\text { Child } \\
\end{array}$ & $\begin{array}{c}24 \\
6 \\
\end{array}$ & years & EPA, 1991a \\
\hline $\begin{array}{l}\text { Body Weight } \\
\text { Adult } \\
\text { Child } \\
\end{array}$ & $\begin{array}{l}70 \\
15 \\
\end{array}$ & $\mathrm{~kg}$ & $\begin{array}{ll}\text { EPA, 1991a } \\
\end{array}$ \\
\hline $\begin{array}{l}\text { Averaging Time: } \\
\text { Carcinogens } \\
\text { Noncarcinogens } \\
\text { Adult } \\
\text { Child } \\
\end{array}$ & $\begin{array}{l}25,550 \\
8,760 \\
2,190 \\
\end{array}$ & $\begin{array}{l}\text { days } \\
\text { days }\end{array}$ & EPA, 1989 \\
\hline \multicolumn{4}{|c|}{ RESIDENTIAL DERMAL CONTACT WITH SOIL } \\
\hline Adherence Factor & 1.0 & $\mathrm{mg} / \mathrm{cm}^{2}$ & EPA, 1992 \\
\hline Absorption Fraçtion & $\begin{array}{l}\text { chemical } \\
\text { specific }\end{array}$ & unitless & DTSC, 1993 (see Table I.3-2) \\
\hline $\begin{array}{l}\text { Skin Surface Area } \\
\text { Adult } \\
\text { Child } \\
\end{array}$ & $\begin{array}{l}5000 \\
2000^{\circ}\end{array}$ & $\mathrm{cm}^{2} /$ event. & EPA, 1992 \\
\hline Exposure Frequency & 180 & event/year & Value assumed, due to snow cover \\
\hline $\begin{array}{l}\text { Exposure Duration } \\
\text { Adult } \\
\text { Child } \\
\end{array}$ & $\begin{array}{c}24 \\
6 \\
\end{array}$ & years & EPA, 1991a \\
\hline $\begin{array}{l}\text { Body Weight } \\
\text { Adult } \\
\text { Child } \\
\end{array}$ & $\begin{array}{l}70 \\
15 \\
\end{array}$ & $\mathrm{~kg}$ & EPA, $1991 a$ \\
\hline $\begin{array}{l}\text { Averaging Time: } \\
\text { Careinogens } \\
\text { Noncarcinogeris } \\
\text { Adult } \\
\text { Child } \\
\end{array}$ & $\begin{array}{l}25,550 \\
8,760 \\
2,190 \\
\end{array}$ & $\begin{array}{l}\text { days } \\
\text { days }\end{array}$ & EPA, 1989 \\
\hline \multicolumn{4}{|c|}{ RESIDENTIAL INHALATION OF DUST } \\
\hline Inhalation Rate & 20 & $\mathrm{~m}^{3} /$ day & EPA, $1991 a$ \\
\hline
\end{tabular}


Table 1.3-3

Exposure Parameters

(Page 2 of 2)

\begin{tabular}{|c|c|c|c|}
\hline Parameter & Value & Units & Reference/Rationale \\
\hline Exposure Frequency & 180 & day/year & Value assumed, due to snow cover \\
\hline Exposure Duration & 30 & years & EPA, 1991a \\
\hline Body Weight & 70 & $\mathrm{~kg}$ & EPA, 1991a \\
\hline $\begin{array}{l}\text { Averaging Time: } \\
\text { Carcinogens } \\
\text { Noncarcinogens }\end{array}$ & $\begin{array}{l}25,550 \\
10,950 \\
\end{array}$ & $\begin{array}{l}\text { days } \\
\text { days }\end{array}$ & EPA, 1989 \\
\hline \multicolumn{4}{|c|}{ RESIDENTIAL INGESTION OF GROUNDWATER } \\
\hline Ingestion Rate & 2 & Lday & EPA, 1991a \\
\hline Fraction Ingested & 1 & unitless & Assumes all of soil intake from site \\
\hline Exposure Frequency & 180 & day/year & Value assumed, due to snow cover \\
\hline Exposure Duration & 30 & years & EPA, 1991a \\
\hline Body Weight & 70 & $\mathrm{~kg}$ & EPA, $1991 a$ \\
\hline $\begin{array}{l}\text { Averaging Time: } \\
\text { Carcinogens } \\
\text { Noncarcinogens } \\
\end{array}$ & $\begin{array}{l}25,550 \\
10,950 \\
\end{array}$ & $\begin{array}{l}\text { days } \\
\text { days }\end{array}$ & EPA, 1989 \\
\hline \multicolumn{4}{|c|}{ RESIDENTIAL DERMAL CONTACT WITH GROUNDWATER (SHOWERING) } \\
\hline Dermal Permeability Constant & $\begin{array}{c}\text { chemical } \\
\text { specific }\end{array}$ & $\mathrm{cm} / \mathrm{hr}$ & EPA, 1992, (see Table 1.3-2) \\
\hline Skin Surface Area & 23,000 & $\mathrm{~cm}^{2}$ & EPA, 1992 \\
\hline Exposure Duration & 30 & years & EPA, 1991a \\
\hline Exposure Frequency & 180 & day/year & Value assumed, due to snow cover \\
\hline Exposure Time & 0.25 & $\mathrm{hr} /$ day & EPA, 1991a \\
\hline Body Weight . & 70 & $\mathrm{~kg}$ & EPA, 1991a \\
\hline $\begin{array}{l}\text { Averaging Time: } \\
\text { Carcinogens } \\
\text { Noncarcinogens } \\
\end{array}$ & $\begin{array}{l}25,550 \\
10,950 \\
\end{array}$ & $\begin{array}{l}\text { days } \\
\text { days }\end{array}$ & EPA, 1989 \\
\hline \multicolumn{4}{|c|}{ RESIDENTIAL INHALATION OF VOCS (SHOWERING) } \\
\hline Inhalation Rate & 0.6 & $\mathrm{~m}^{3} / \mathrm{hr}$ & EPA, 1991a \\
\hline Exposure Frequency & 180 & day/year & Value assumed, due to snow cover \\
\hline Exposure Duration & 30 & years & EPA, 1991a \\
\hline Exposure Time & 0.25 & hr/day & EPA, 1991a \\
\hline Body Weight & 70 & $\mathrm{~kg}$ & EPA, 1991a \\
\hline $\begin{array}{l}\text { Averaging Time: } \\
\text { Carcinogens } \\
\text { Noncarcinogens }\end{array}$ & $\begin{array}{l}25,550 \\
10,950\end{array}$ & $\begin{array}{l}\text { days } \\
\text { days }\end{array}$ & EPA, 1989 \\
\hline
\end{tabular}


Table I.3-4

Intake Concentrations for Subsurface Soil at the SGZ Mud Pits of Rulison

\begin{tabular}{|c|c|c|c|}
\hline \multirow{2}{*}{ Exposure Pathway } & \multirow{2}{*}{ Constituent } & \multicolumn{2}{|c|}{$\begin{array}{c}\text { Estimated Intake } \\
\text { (mg/kg-day) }\end{array}$} \\
\hline & & Carcinogenic & Noncarcinogenic \\
\hline \multirow[t]{10}{*}{ Incidental Ingestion } & Barium & $N A^{a}$ & 7.30E-03 \\
\hline & Benzene & 4.11E-08 & NA \\
\hline & Chromium III & NA & 3.02E-04 \\
\hline & Chromium VI & NA & $6.03 E-05$ \\
\hline & Ethylbenzene & NA & 1.73E-06 \\
\hline & Lead & NA & 3.41E-04 \\
\hline & Toluene & NA & 2.04E-07 \\
\hline & TPH as Diesel & NA & 1.19E-02 \\
\hline & Xylene & NA & 2.79E-05 \\
\hline & Tritium & $1.56 \mathrm{E}+02(\mathrm{pCi})$ & NA \\
\hline \multirow[t]{10}{*}{ Dermal Contact } & Barium & NA & $1.01 E-03$ \\
\hline & Benzene & $9.03 E-08$ & NA \\
\hline & Chromium III & NA & 4.18E-05 \\
\hline & Chromium VI & NA & 8.36E-06 \\
\hline & Ethylbenzene & NA & $2.40 \mathrm{E}-06$ \\
\hline & Lead & NA & 4.74E-05 \\
\hline & Toluene & NA & 2.83E-07 \\
\hline & TPH as Diesel & NA & $4.95 E-03$ \\
\hline & Xylene & NA & 3.87E-05 \\
\hline & Tritium & $2.84 E+00(p C i)$ & NA \\
\hline \multirow[t]{10}{*}{ Inhalation of Dust } & Barium & NA & 7.94E-07 \\
\hline & Benzene & $1.73 E-11$ & NA \\
\hline & Chromium III & NA & $3.28 E-08$ \\
\hline & Chromium VI & 2.81E-09 & NA . \\
\hline & Ethylbenzene & NA & $1.88 E-10$ \\
\hline & Lead & NA & $3.71 \mathrm{E}-08$ \\
\hline & Toluene & NA & 2.22E-011 \\
\hline & TPH as Diesel & NA & $1.29 E-06$ \\
\hline & Xylene & NA & 3.03E-09 \\
\hline & Tritium & $7.28 \mathrm{E}-02(\mathrm{pCi})$ & NA \\
\hline
\end{tabular}

${ }^{a_{\text {Not applicable }}}$ 
Table I.3-5

Intake Concentrations for Groundwater in the Vicinity of Rulison

\begin{tabular}{|c|c|c|c|}
\hline \multirow[t]{2}{*}{ Exposure Pathway } & \multirow[t]{2}{*}{ Constituent } & \multicolumn{2}{|c|}{$\begin{array}{c}\text { Estimated Intake } \\
\text { (mg/kg-day) }\end{array}$} \\
\hline & & Carcinogenic & Noncarcinogenic \\
\hline \multirow[t]{10}{*}{ Incidental Ingestion } & Barium & NA & $3.64 \mathrm{E}-03$ \\
\hline & Benzene & $6.04 \mathrm{E}-06$ & NA \\
\hline & Chromium III & NA & 2.35E-04 \\
\hline & Chromium VI & NA & 4.70E-05 \\
\hline & Ethylbenzene & NA & $1.41 \mathrm{E}-05$ \\
\hline & Lead & NA & 7.19E-05 \\
\hline & Toluene & NA & 1.41E-05 \\
\hline & TPH as Diesel & NA & 7.05E-03 \\
\hline & Xylene & NA & 2.11E-05 \\
\hline & Tritium & $2.74 E+06(p C i)$ & $N A^{a}$ \\
\hline \multirow{10}{*}{$\begin{array}{l}\text { Dermal Contact while } \\
\text { Showering }\end{array}$} & Barium & NA & 1.05E-05 \\
\hline & Benzene & 3.65E-07 & NA \\
\hline & Chromium III & NA & $6.75 \mathrm{E}-07$ \\
\hline & Chromium VI & NA & 1.35E-07 \\
\hline & Ethylbenzene & NA & 3.00E-06 \\
\hline & Lead & NA & 2.07E-07 \\
\hline & Toluene & NA & $1.82 E-06$ \\
\hline & TPH as Diesel & NA & 4.25E-04 \\
\hline & Xylene & NA & 4.86E-06 \\
\hline & Tritium & $1.26 \mathrm{E}+03(\mathrm{pCi})$ & NA \\
\hline \multirow{10}{*}{$\begin{array}{l}\text { Inhalation of VOCs While } \\
\text { Showering }\end{array}$} & Barium & NA & $\mathrm{NA}$ \\
\hline & Benzene & 3.26E-07 & NA \\
\hline & Chromium III & NA & NA \\
\hline & Chromium VI & NA & NA \\
\hline & Ethylbenzene & NA & $1.18 E-06$ \\
\hline & Lead & NA & NA \\
\hline & Toluene & NA & 6.33E-07 \\
\hline & TPH as Diesel & NA & NA \\
\hline & Xylene & NA & 2.25E-06 \\
\hline & Tritium & $2.73 E+04(p C i)$ & NA \\
\hline
\end{tabular}

${ }^{\mathrm{a}}$ Not applicable 


\section{I.3.2.2.1 Dermal Contact with Groundwater}

The following is the intake equation for dermal absorption of chemicals due to contact with groundwater:

$$
A D=\frac{C_{i} \times S A \times P C \times C F \times E T \times E F \times E D}{B W \times A T}
$$

where
$\mathrm{AD}=$ Absorbed dose (mg/kg-day)
$\mathrm{C}_{\mathrm{i}}=$ Chemical concentration in shower water, adjusted for volatilization (mg/L)
$\mathrm{SA}=$ Skin surface area available for contact $\left(\mathrm{cm}^{2}\right)$
PC = Chemical-specific dermal permeability (EPA, 1992) (see Table I.3-2 for specific values)
$\mathrm{CF}=$ Conversion factor $\left(10^{-3} \mathrm{~L} / \mathrm{cm}^{3}\right)$
$\mathrm{ET}=$ Exposure time (hr/day)
$\mathrm{EF}, \mathrm{ED}, \mathrm{BW}$, and $\mathrm{AT}$ are defined in Section I.3.2.1.

\section{I.3.2.3 Exposure Parameters}

Three types of parameters are used in exposure models to estimate intake (EPA, 1989):

- Constituent-related parameters (i.e., exposure point concentrations)

- Parameters that describe the exposed population (e.g., contact rate, exposure frequency and duration, and body weight)

- Toxicity-related parameters (i.e., slope factors and reference doses). 


\subsubsection{Toxicity Assessment}

Toxicity information is given in the same units provided by the source material (dose rates and concentrations are primarily used). In a few cases, however, conversions were made as specifically indicated in Section 1.4.1. Toxicological profiles for each constituent of potential concern are presented separately in this chapter, along with the corresponding Chemical Abstracts Service Registry Number (CASRN).

The EPA weight-of-evidence classification (cancer class) system for carcinogenicity is presented here for reference. The classification is as follows (EPA, 1989):

- Class A-Human carcinogen

- Class B1-Probable human carcinogen; limited human data available

- Class B2-Probable human carcinogen; sufficient evidence in animals; inadequate or no evidence in humans

- Class C-Possible human carcinogen

- Class D-Not classifiable as to human carcinogenicity

- Class E-Evidence of noncarcinogenicity for humans

Slope factors are typically calculated for potential carcinogens in Classes A, B1, and B2. Quantitative estimation of slope factors for chemicals in Class $C$ proceeds on a case-by-case basis.

The primary source for toxicity values, both reference doses (RfD) and slope factors (SF), is the Integrated Risk Information System (IRIS) (EPA, 1996). If a toxicity value for a given chemical is not available in IRIS, the secondary source is the Health Effects Assessment Summary Tables (HEAST) (EPA, 1995). For TPH, an EPA Region II reference document provided a reference dose (EPA, 1993). No surrogate values were developed for chemicals for which no toxicity information existed in one of the above references.

\subsubsection{Toxicological Profiles}

Barium, CASRN 7440-39-3. Barium is a silver-white, malleable metal. It is rarely encountered in elemental form but more often in ores or as an ion. In that form, barium is relatively abundant 
in nature and occurs in plant and animal tissues. Barium is used primarily as a carrier for radium and in alloys of barium and aluminum or magnesium. Barium is a common additive to drilling mud, and is naturally occurring in areas of igneous origin as supported by the concentration of barium detected in the upgradient background monitoring well RU-03. From soluble compounds, barium is absorbed in small quantities into the human body and retained there. The daily intake is about $0.75 \mathrm{mg}$, but the retention time is short--probably less than a day (ICRP, 1975). The considerable oral toxicity of barium is usually masked by the low solubility of most common barium compounds. In soluble form, however, it leads to gastroenteritis and to effects on the heartbeat, up to and including ventricular fibrillations (Doull et al., 1980). By inhalation, barium ores (mostly barium sulfate and barium carbonate) lead to a mild form of pneumoconiosis, which is usually reversible after termination of the exposure. The reference concentration (RfC) for barium is $5.0 \times 10^{-4} \mathrm{mg} / \mathrm{kg}$-day for inhalation, and the $\mathrm{RfD}$ is $7.0 \times 10^{-3}$ $\mathrm{mg} / \mathrm{kg}$-day for ingestion, with an uncertainty factor of 3 (EPA, 1996; EPA, 1995). The cancer class and SFs for barium are unknown at this time.

Chromium, CASRN 16065-83-1. The primary uses of chromium are for plating metals, steel fabrication, paint and pigment manufacturing, and leather tanning. The likely source of chromium at the site is chromium lignosulfonate, a drilling mud additive. Chromium exists in several valence states; however, only the trivalent and hexavalent states are biologically . significant. For this risk assessment, the hexavalent state was initially considered because of its high toxicity. Hexavalent chromium is a Class A carcinogen. Acute exposure to chromium compounds causes dermatitis, penetrating ulcers on the hands and forearms, perforation of the nasal septum, and inflammation of the larynx and liver. Epidemiologic studies indicate that chromate is a carcinogen, with bronchogenic carcinoma as the principal lession. The relative risk to chromate plant workers in the development of respiratory cancer is 20 times greater than in the general population (Doull et al., 1980). The oral RfD for chromium-VI is $5.0 \times 10^{-3} \mathrm{mg} / \mathrm{kg}$-day (EPA, 1996), with an uncertainty factor of 500. No inhalation $\mathrm{RfC}$ is reported. The inhalation $\mathrm{SF}$ for chromium-VI is $42 \mathrm{~kg}$-day/mg (EPA, 1995). The oral RfD for chromium-II is $1.0 \mathrm{mg} / \mathrm{kg}$-day (EPA, 1996), with an uncertainty factor of 100 . No other values are available for chromium-III.

Lead and Inorganic Lead Compounds, CASRN 7439-92-1. The toxicity of lead and its compounds has probably received more attention than most other metals. Lead is used as a construction material for tank linings, piping, and equipment-handling corrosive gases and liquids. On the basis of the data generated in these investigations, there are a number of standards for air and water. Lead is a regular contaminant in most foods, resulting in a daily 
intake of about $0.4 \mathrm{mg}$ (ICRP, 1975). However, even at low levels of exposure, some human responses to chronic lead poisoning have been found. The toxic effects of lead are widespread, encompassing the central nervous system, the peripheral nervous system, the kidneys, and the blood. The EPA has published no oral RfD for lead because its toxicity is thought not to demonstrate a threshold.

There is sufficient evidence of carcinogenicity in animal experiments with lead compounds to classify lead and its inorganic compounds as probable Class B2 human carcinogens. Kidney tumors were observed in these experiments, although usually only at high doses. However, because of problems with dosimetry, no estimates for the SFs are currently available.

Benzene, CASRN 71-43-2. Benzene is a clear, colorless liquid (boiling point 80.1 degrees Celsius $\left[{ }^{\circ} \mathrm{C}\right]$, melting point $5.51^{\circ} \mathrm{C}$ [Sax, 1989]). It has widespread use in the chemical and drug industries and is used as a solvent for paints, resins, lacquers, and plastics. The likely source of benzene at the site is diesel fuel used as a drilling mud additive. Exposures in humans occur mostly by inhalation because of the high volatility of benzene. In acute exposure, benzene toxicity appears primarily to have an effect on the central nervous system; an exposure of 20,000 parts per million (ppm) for humans is usually fatal within 5 to 10 minutes. Symptoms of intoxication are drowsiness, dizziness, headache, and loss of consciousness (Doull et al., 1980). Chronic exposure rather than acute exposure to benzene is a primary concern in industry. It is a leukemogen, and daily exposure to a concentration of $100 \mathrm{ppm}$ or less will usually cause damage if continued over a protracted period of time. The early symptoms of chronic benzene poisoning consist of headaches, fatigue, and loss of appetite (Sax, 1989). Benzene is a Class A human carcinogen, with oral and inhalation SFs of $2.9 \times 10^{-2} \mathrm{~kg}$-day $/ \mathrm{mg}$ from IRIS (EPA, 1996).

Ethylbenzene, CASRN 100-41-4. Ethylbenzene is a colorless, flammable liquid (boiling point $136.2^{\circ} \mathrm{C}$ ) with an aromatic odor. It is primarily used in the production of styrene and synthetic polymers, as a solvent, and as a component in fuels (Sax, 1989). The likely source of ethylbenzene at the site is diesel fuel used as a drilling mud additive. Ethylbenzene is absorbed primarily through the respiratory system. In low concentrations, the vapor is an irritant to the eyes, nose, and throat and may cause dizziness, leading to a sense of constriction of the chest. In chronic exposures, the compound is a kidney and liver toxin. Ethylbenzene has an oral RfD of $1.0 \times 10^{-1} \mathrm{mg} / \mathrm{kg}$-day, with an uncertainty factor of 1,000 , and an inhalation RfC of $2.9 \times 10^{-1}$ $\mathrm{mg} / \mathrm{kg}$-day, with an uncertainty factor of 300 (EPA, 1996). The compound is not considered to be a potential human carcinogen (Class $D$ ), and, therefore, no SFs are available. 
Toluene, CASRN 108-88-3. Toluene is a colorless, volatile liquid (boiling point $110.4^{\circ} \mathrm{C}$ ) that is widely used as a solvent in paints, varnishes, and glues (Sax; 1989). It also serves as an intermediate compound in the synthesis of organic substances. The likely source of toluene at the site is diesel fuel used as a drilling mud additive. At high levels of exposure, toluene is a narcotic and thus affects the central nervous system, leading to fatigue, weakness, and confusion. In low chronic exposures, toluene can cause damage to the liver and kidney. It has an RfD for chronic ingestion of $2.0 \times 10^{-1} \mathrm{mg} / \mathrm{kg}$-day and a chronic inhalation RfC of $1.1 \times 10^{-1} \mathrm{mg} / \mathrm{kg}$-day (EPA, 1996). The uncertainty factors for toluene are 1,000 for oral exposure and 300 for inhalation. Toluene is not suspected of being carcinogenic (Class D), and therefore, no SFs are available.

Total Petroleum Hydrocarbons as Diesel. TPH as diesel is a mixture of organic hydrocarbons. The combined effects of these chemicals are considered when determining the risk for a given pathway. Although no reference doses are available in IRIS or HEAST, an EPA Region II document describes an oral RfD of 0.6 developed by the State of Massachusetts (EPA, 1993), and that value was used in this study.

Xylene, CASRN 1330-20-7. Xylene is a mixture of the three different isomers (0-, $\mathrm{p}-$, and $\mathrm{m}-$ ) of dimethylbenzene; however, it consists mostly of the last two. It is a clear liquid that boils at 130 to $150^{\circ} \mathrm{C}$, depending on the mixture (Sax, 1989). Xylene is a solvent used in resins, lacquers, and enamels and is also used in the synthesis of organic compounds, in aviation gasoline, and in other engine fuels. The likely source of xylene at the site is diesel fuel used as a drilling mud additive. Xylene is moderately toxic by inhalation and ingestion and is an eye and skin irritant in high concentrations. On inhalation, xylene can lead to lung damage. At low exposure levels, liver and kidney damage may occur. The ingestion RfD is $2.0 \mathrm{mg} / \mathrm{kg}$-day, with an uncertainty factor of 100 (EPA, 1996), but no value is listed for inhalation RfC. There is no evidence of carcinogenic activity (Class $D$ ). in humans or laboratory animals exposed to xylenes (EPA, 1996), and, therefore, no SFs exist.

Tritium CASRN 010028-17-8. At most tritium facilities, the most commonly encountered forms of tritium are tritium gas (HT) and tritium oxide (HTO). Other forms of tritium may be present, such as a metal tritides, tritiated pump oil, and tritiated gases such as methane and ammonia. As noted earlier, deuterated and tritiated compounds generally have the same chemical properties as their protium counterparts, although some minor isotopic differences in reaction rates exist. These various tritiated compounds have a wide range of metabolic properties in humans under similar exposure conditions. For example, inhaled tritium gas is only slightly incorporated into 
the body during exposure, and the remainder is rapidly removed (by inhalation) following the exposure. On the other hand, tritiated water vapor is readily taken up and retained in the body water (tritium half-life is $12.3 \mathrm{yrs}$ ). The slope factor for tritium is $7.15 \mathrm{E}-14 \mathrm{pCi}^{-1}$ for ingestion, and the slope factor is $9.59 \mathrm{E}-14 \mathrm{pCi}^{-1}$ for inhalation (EPA, 1995).

\section{I.4.2 Toxicity Summary}

Table 1.4-1 summarizes the toxicity information, including the constituent of potential concern RfDs, slope factors, and EPA cancer classification.

Table 1.4-1

Summary of Toxicity Data for COPCs at Rulison, Colorado

\begin{tabular}{|c|c|c|c|c|c|}
\hline \multicolumn{6}{|c|}{ Radiological Slope Factors } \\
\hline Radionuclides & $\begin{array}{c}\text { Half Life } \\
\text { (years) }\end{array}$ & $\begin{array}{l}\text { Ingestion } \\
\text { (risk/pCi) }\end{array}$ & \multicolumn{2}{|c|}{$\begin{array}{c}\text { Inhalation } \\
\text { (risk/pCi) }\end{array}$} & $\begin{array}{r}\text { External } \\
\text { Exposure } \\
\text { (risk/pCi-g) } \\
\end{array}$ \\
\hline Tritium & 12.3 & $7.15 \times 10^{-14 a}$ & \multicolumn{2}{|c|}{$9.59 \times 10^{-14 a}$} & 0.00 \\
\hline \multicolumn{6}{|c|}{ Chemical Toxicity Values } \\
\hline Chemicals & $\begin{array}{c}\text { Oral RfD } \\
\text { (mg/kg-day) }\end{array}$ & $\begin{array}{c}\text { Inhalation RfC } \\
\text { (mg/kg-day) }\end{array}$ & $\begin{array}{l}\text { Cancer } \\
\text { Clas's }\end{array}$ & $\begin{array}{c}\text { Oral } \\
\text { Slope Factor } \\
\text { (mg/kg-day) }^{-1}\end{array}$ & $\begin{array}{c}\text { Inhalation } \\
\text { Slope } \\
\text { Factor } \\
\text { (mg/kg-day) }{ }^{-1}\end{array}$ \\
\hline Barium & $0.07^{b}$ & $0.0005^{a}$ & No Data & No Data & No Data \\
\hline Benzene & No Data & No Data & $A^{c}$ & $0.029^{b}$ & $0.029^{b}$ \\
\hline Chromium III & $1.0^{b}$ & No Data & No Data & No Data & No Data \\
\hline Chromium Vl & $0.005^{b}$ & No Data & A & No Data & $42^{2}$ \\
\hline Ethylbenzene & $0.1^{b}$ & $0.29^{b}$ & $D^{d}$ & $N^{b}$ & NA \\
\hline Lead & No Data & No Data & $\mathrm{B} 2^{\mathrm{b}}$ & No Data & No Data \\
\hline Toluene & $0.2^{b}$ & $0.11^{b}$ & $\mathrm{D}$ & NA & NA \\
\hline TPH as Diesel & $0.6^{g}$ & No Data & . NA & No Data & No Data \\
\hline Xylene & $2.0^{b}$ & No Data & $\mathrm{D}$ & NA & NA \\
\hline
\end{tabular}

\footnotetext{
${ }^{a} E P A, 1995$

EPA, 1996

Human carcinogen

Not classifiable as to human carcinogenicity

Not applicable

Probable human carcinogen; sufficient evidence in animals; inadequate or no evidence in humans

$9_{\text {EPA, } 1993}$
} 


\section{I.5.0. Risk Characterization}

This section provides a characterization of the potential health risks associated with the intake of constituents of potential concern in subsurface soil. Risk characterization compares estimated potential cancer risks with reasonable levels of risk (slope factors) for carcinogens and compares estimated daily intake (rate) with reference levels (reference doses) for noncarcinogens.

Carcinogens may also pose a systemic (noncarcinogenic) hazard, and these potential hazards are characterized in the same manner as other noncarcinogens.

Estimation of potential risk from exposure to the COPCs is based on RAGS (EPA, 1989). This assessment employs a health-protective bias that leads to a conservative estimation of the risk. The exposure of individuals to an RME is described in Section I.3.1 and evaluated in Section I.3.2 to provide estimates of daily intakes. These estimated intakes (rates) are evaluated with the individual chemical toxicological values (Section I.4.1) to determine the potential carcinogenic risks and the potential hazards to human health.

\subsubsection{Estimation of Carcinogenic Risk}

In evaluating the calculated residential exposure from potentially carcinogenic COPCs, a reasonable level of risk must be selected. The EPA uses an incremental lifetime cancer risk (ILCR) (also referred to as excess cancer risk) of 1 in $10,000\left(1 \times 10^{-4}\right)$ as the upper limit of acceptable risk at contaminated sites. In addition, in the National Contingency Plan (NCP) (CFR, 1990), the EPA specifies a risk range of $10^{-6}$ to $10^{-4}$ for developing remediation goals for the purpose of developing and evaluating remedial alternatives for contaminated media. .

Based on the regulatory precedents cited above, a reasonable and appropriate maximum acceptable ILCR for the site would be $10^{-4}$. As implemented under the NCP, pathway risks greater than $10^{-6} \mathrm{ILCR}$ must receive risk management consideration (CFR, 1990). The quantitative risk assessment is one of many factors that is considered in the decision-making process for remediation. Therefore, there is no single risk value that defines "acceptable" and "unacceptable" risk. The purpose of this risk assessment is to present quantitative and qualitative estimates of potential risk, and thus, all pathway risks greater than the lower bound of $10^{-6}$ will be examined.

Cumulative site ILCRs were developed for subsurface soil and groundwater COPCs. These cumulative ILCRs included all media and pathways that were appropriate to combine. These 
pathways occur when there is potential for an individual to be exposed to multiple pathways at the same given instant in time. Where the cumulative $\mathbb{L C R}$ site risk to an individual based on the RME for both current and future land use is less than $10^{-4}$, action generally is not warranted unless there are adverse environmental impacts (EPA, 1991b).

The carcinogenic risk is estimated as the probability of an additional incidence of cancer. This risk is:

$$
\text { ILCR }=\text { SF } \times \text { Intake }
$$

where

$$
\begin{aligned}
& \mathrm{ICR}=\text { Incremental lifetime cancer risk (unitless) } \\
& \mathrm{SF} \quad=\text { Carcinogenic } \mathrm{SF}\left[(\mathrm{mg} / \mathrm{kg} \text {-day })^{-1}\right] \\
& \text { Intake }=\text { Chronic daily intake averaged over a } 70 \text {-year lifetime }(\mathrm{mg} / \mathrm{kg} \text {-day). }
\end{aligned}
$$

The carcinogenic SFs for the constituents of potential concern are presented in Table I.4-1. These are the most recent values cited in the EPA's IRIS (EPA, 1996), and the HEAST (EPA, 1995). Surrogate values for constituents were not derived where no SF existed in the IRIS or the HEAST.

For a given pathway and medium with exposure to several carcinogens, the following equation was used to sum the cancer risk:

$$
\operatorname{Risk}_{t, p}=\sum_{i=1}^{I} I L C R_{p}\left(\text { chem }_{i}\right)
$$

where

$$
\begin{array}{lll}
\text { Risk }_{t, \mathrm{p}} & = & \text { Total cancer risk for pathway } \mathrm{p} \text { (unitless) } \\
\operatorname{ICCR}_{\mathrm{p}}\left(\mathrm{chem}_{\mathrm{i}}\right) \quad=\quad \begin{array}{l}
\text { Individual cancer risk for constituent } \mathrm{i} \text { through exposure pathway } \mathrm{p} \\
\text { (unitless) }
\end{array}
\end{array}
$$

Estimates of ILCRs are provided for each exposure scenario and pathway in Section I.5.3. 


\subsubsection{Estimation of Noncarcinogenic Risk}

Constituents that pose a health threat other than cancer were evaluated by comparing an exposure level or intake to an acceptable level or RfD. The ratio of estimated daily intake to the RfD is termed the hazard quotient $(\mathrm{HQ})$ and is defined as

$$
H Q_{i, p}=\frac{I_{i, p}}{R f D_{i}}
$$

where

$\mathrm{HQ}_{\mathrm{i}, \mathrm{p}}=$ Individual $\mathrm{HQ}$ for exposure to constituent $\mathrm{i}$ through exposure pathway $\mathrm{p}$ (unitless)

$\mathrm{I}_{\mathrm{i}, \mathrm{p}} \quad=$ Daily intake via a specific pathway $\mathrm{p}$ for constituent $\mathrm{i}(\mathrm{mg} / \mathrm{kg}$-day)

$\mathrm{RfD}_{\mathrm{i}}=\mathrm{RfD}$ for exposure by the specific pathway (limited to oral and inhalation values) for constituent i (mg/kg-day).

The RfD is an estimate of the intake level to which a human population, including sensitive subpopulations, may be chronically exposed without a significant risk of adverse health effects (EPA, 1989). The RfDs for the constituents of potential concern are listed in Table I.4-1. Because the HQ does not define intake response relationships, its numerical value should not be construed as a direct estimate of risk, but it does suggest that a given situation should be more closely scrutinized. The concept of the HQ implies the existence of a threshold for systemic health effects. The HQ is a numerical indication of the fraction of acceptable limits of exposure or the degree to which acceptable exposure levels are exceeded. As this quotient increases toward unity, concern for the potential hazard of the constituent increases. A value above unity is an indication of risk, although a direct correlation to the magnitude of the risk cannot be drawn. The RfDs used in this risk assessment are the most recent values cited in the IRIS (EPA, 1996) and HEAST (EPA, 1995), and for TPH, an EPA Region II document (EPA, 1993). No surrogate values were derived.

In the case of simultaneous exposure to several constituents, the hazard index (HI) is calculated to evaluate the potential risk from exposure to the mixture by summing the HQs for each 
chemical, medium, and pathway. The total HI incorporates the assumption of additive effects when dealing with a mixture of components. The HI formula is as follows (EPA, 1989):

$$
H I=\sum_{i=1}^{I} H Q_{i}
$$

where

$$
\begin{aligned}
& \mathrm{HI}=\text { Hazard index (unitless) } \\
& \mathrm{HQ}_{\mathrm{i}}=\text { Hazard quotient for exposure to constituent } \mathrm{i} \text { (unitless) }
\end{aligned}
$$

Summation of the individual HQs could result in an HI that exceeds 1 , even if no single chemical exceeds its acceptable level. Mechanistically, it is not appropriate to sum HQs unless the constituents that make up the mixture have similar effects on the identical organ: Consequently, the summing of HQs for a mixture of compounds that are not expected to include the same type of effects could overestimate the potential risk. The EPA recommends that if the total HI is greater than unity, the components of the mixture should be grouped by critical effect, and separate hazard indices should be calculated for each effect.

\subsubsection{Results of the Human Health Risk Assessment}

Risk for inorganic lead was calculated using the California Department of Toxic Substance Control LEADSPREAD model (DTSC, 1992). The model was run with the plant uptake turned “off” because secondary pathways were not considered at Rulison. There are no regional data for lead in air at Rulison, so the LEADSPREAD default value of 0.15 micrograms $[\mu \mathrm{g}] / \mathrm{m}^{3}$ was assumed. The maximum detected soil concentration of $119 \mathrm{mg} / \mathrm{kg}$ and the maximum detected groundwater concentration of $5.1 \mu \mathrm{g} / \mathrm{L}$ were used as input parameters. The output is summarized as blood level concentrations for three potential receptor groups: adult, child (the most sensitive population), and occupational. The child blood level for Rulison at the 99th percentile was calculated to be $7.2 \mu \mathrm{g} /$ decaliter [ $\mathrm{dL}$ ] of blood. The lead whole body level of concern is 10 $\mu \mathrm{g} / \mathrm{dL}$ of whole blood with a 0.01 risk of exceeding this value (DTSC, 1992). Therefore, based on the above results, lead both in soil and groundwater at Rulison does not exceed the established blood levels of concern. 


\section{I.5.3.1 SGZ Mud Pits}

Table I.5-1 summarizes the risks for the subsurface soil pathway for the SGZ mud.pits. Included in this summary is the ILCR and HQ for each chemical of potential concern and pathway, and pathway total ILCRs and HIs.

The human health risk assessment suggests that the level of contamination found on an individual COPC basis at this site for the examined medium (subsurface soil) does not pose a significant risk. None of the individual COPC risks is above an HQ of 1.0 or an ILCR of $1 \times 10^{-6}$.

For the SGZ mud pit soils, no total ILCRs and HIs exceed suggested guidance levels (an ILCR of $1 \times 10^{-4}$ or $\mathrm{HI}$ of 1.0) established by both state and federal regulators (see Sections I.5.1 and I.5.2 above).

\subsubsection{Groundwater}

Table I.5-2 summarizes the risks for the groundwater pathway at Rulison. Included in this summary is the ICR and HQ for each constituent of potential concern and pathway, and pathway total ILCRs and HIs.

The human health risk assessment suggests that the level of contamination found on an individual COPC basis at these sites for the examined medium (groundwater) does not pose a significant risk. None of the individual COPC risks is above an HQ of 1.0 or an $\mathbb{L C R}$ of $1 \times 10^{-6}$.

For the drilling effluent pond and SGZ mud pits area groundwater, no total ILCRs and HIs exceed suggested guidance levels (an ILCR of $1 \times 10^{-4}$ or HI of 1.0) established by both state and federal regulators (see Sections I.5.1 and I.5.2 above). 
Table 1.5-1

Incremental Lifetime Cancer Risks and Hazard Quotients/Indices for Future Residential Exposure to Subsurface Soil at the SGZ Mud Pits (Page 1 of 2)

\begin{tabular}{|c|c|c|c|}
\hline Exposure Route & Chemical/Radionuclide & $\begin{array}{c}\text { Hazard } \\
\text { Quotient//ndex }\end{array}$ & ILCR $^{\mathrm{a}}$ \\
\hline \multirow[t]{11}{*}{ Incidental Ingestion } & Barium & $1.0 \times 10^{-01}$ & $N D^{b}$ \\
\hline & Benzene & ND & $1.2 \times 10^{-09}$ \\
\hline & Chromium III & $3.0 \times 10^{-04}$ & ND \\
\hline & Chromium V! & $1.2 \times 10^{-02}$ & ND \\
\hline & Ethylbenzene & $1.7 \times 10^{-05}$ & $N A^{c}$ \\
\hline & Lead & ND & ND \\
\hline & Toluene & $1.0 \times 10^{.06}$ & NA \\
\hline & TPH as Diesel & $2.0 \times 10^{-02}$ & ND \\
\hline & Xylene & $1.4 \times 10^{.05}$ & NA \\
\hline & Tritium & NA & $1.1 \mathrm{E}-11$ \\
\hline & Pathway Totals & $1.4 \times 10^{-01}$ & $1.2 \times 10^{-09}$ \\
\hline \multirow[t]{11}{*}{ Dermal Contact } & Barium & $1.4 \times 10^{-02}$ & ND \\
\hline & Benzene & ND & $2.6 \times 10^{-09}$ \\
\hline & Chromium III & $4.2 \times 10^{-05}$ & ND \\
\hline & Chromium VI & $1.7 \times 10^{-03}$ & ND \\
\hline & Ethylbenzene & $2.4 \times 10^{-05}$ & NA \\
\hline & Lead & ND & ND \\
\hline & Toluene & $1.4 \times 10^{-06}$ & NA \\
\hline & TPH as Diesel & $8.2 \times 10^{-03}$ & ND \\
\hline & Xylene & $1.9 \times 10^{-05}$ & NA \\
\hline & Tritium & NA & ND \\
\hline & Pathway Totals & $2.4 \times 10^{-02}$ & $2.6 \times 10^{-09}$ \\
\hline
\end{tabular}


Table 1.5-1

Incremental Lifetime Cancer Risks and Hazard Quotients/Indices for Future Residential Exposure to Subsurface Soil at theSGZ Mud Pits (Page 2 of 2)

\begin{tabular}{|c|c|c|c|}
\hline Exposure Route & Chemical/Radionuclide & $\begin{array}{c}\text { Hazard } \\
\text { Quotient/Index }\end{array}$ & ILCR $^{\mathrm{a}}$ \\
\hline \multirow[t]{11}{*}{ Inhalation of Dust } & Barium & $5.6 \times 10^{-03}$ & ND \\
\hline & Benzene & ND & $5.0 \times 10^{-13}$ \\
\hline & Chromium III & ND & ND \\
\hline & Chromium VI & ND & $1.2 \times 10^{-07}$ \\
\hline & Ethylbenzene & $6.6 \times 10^{-10}$ & NA \\
\hline & Lead & ND & ND \\
\hline & Toluene & $1.9 \times 10^{-10}$. & NA \\
\hline & TPH as Diesel . & ND & ND \\
\hline & Xylene & ND & NA \\
\hline & Tritium & NA & $7.0 \times 10^{-15}$ \\
\hline & Pathway Totals & $5.6 \times 10^{-03}$ & $1.2 \times 10^{-07}$ \\
\hline
\end{tabular}

Incremental lifetime cancer risk

No toxicity information available for the given pathway.

Table 1.5-2

Incremental Lifetime Cancer Risks and Hazard Quotients/Indices for Future Residential Exposure to Groundwater at Rulison

(Page 1.of 2)

\begin{tabular}{|c|c|c|c|}
\hline Exposure Route & Chemical/Radionuclide & $\begin{array}{l}\text { Hazard Quotient/ } \\
\text { Index }\end{array}$ & ILCR $^{\mathrm{a}}$ \\
\hline \multirow[t]{11}{*}{ Incidental lngestion } & Barium & 5.2E-02 & NA \\
\hline & Benzene & NA & 1.8E-07 \\
\hline & Chromium III & 2.3E-04 & NA \\
\hline & Chromium VI & $9.4 E-03$ & NA \\
\hline & Ethylbenzene & $1.4 \mathrm{E}-04$ & NA \\
\hline & Lead & NA & NA \\
\hline & Toluene & 7.0E-05 & NA \\
\hline & TPH as Diesel & $1.2 \mathrm{E}-02$ & NA \\
\hline & Xylene & $1.1 \mathrm{E}-05$ & NA \\
\hline & Tritium & NA & $2.0 \mathrm{E}-07^{\mathrm{b}}$ \\
\hline & Pathway Totals & 7.4E-02 & 3.8E-07 \\
\hline
\end{tabular}


Table 1.5-2

Incremental Lifetime Cancer Risks and Hazard Quotients/lndices for

Future Residential Exposure to Groundwater at Rulison

(Page 2 of 2)

\begin{tabular}{|c|c|c|c|}
\hline Exposure Route & Chemical/Radionuclide & $\begin{array}{c}\text { Hazard Quotient/ } \\
\text { Index }\end{array}$ & ILCR $^{\mathrm{a}}$ \\
\hline \multirow[t]{11}{*}{ Dermal Contact } & Barium & $1.5 \mathrm{E}-04$ & NA \\
\hline & Benzene & NA & 1.1E-08 \\
\hline & Chromium III & $6.8 \mathrm{E}-07$ & NA \\
\hline & Chromium VI & 2.7E-05 & NA \\
\hline & Ethylbenzene & $3.0 E-05$ & NA \\
\hline & Lead & NA & NA \\
\hline & Toluene & 9.1E-06 & NA \\
\hline & TPH as Diesel & 7.1E-04 & NA \\
\hline & Xylene & 2.4E-06 & NA \\
\hline & Tritium & NA & $9.0 \mathrm{E}-11^{\mathrm{b}}$ \\
\hline & Pathway Totals & 9.3E-04 & $1.1 \mathrm{E}-08$ \\
\hline \multirow{11}{*}{$\begin{array}{l}\text { Inhalation of VOCs } \\
\text { While Showering }\end{array}$} & Barium & NA & NA \\
\hline & Benzene & NA & 9.5E-09 \\
\hline & Chromium III & NA & NA \\
\hline & Chromium VI & NA & NA \\
\hline & Ethylbenzene & 4.1E-06 & NA \\
\hline & Lead & NA & NA \\
\hline & Toluene & $7.6 \mathrm{E}-06$ & NA \\
\hline & TPH as Diesel & NA & NA \\
\hline & Xylene & NA & NA \\
\hline & Tritium & NA & $2.6 \mathrm{E}-09^{b}$ \\
\hline & Pathway Totals & $1.2 E-05$ & 1.2E-08 \\
\hline
\end{tabular}

ancremental lifetime cancer risk

Tritium sampling results are available only from the SGZ mud pits area groundwater monitoring wells. 


\subsubsection{General Uncertainties}

The overriding uncertainties associated with the risk characterization are as follows:

- The extrapolation of toxic effects observed at the high doses necessary to conduct animal studies to effects that might occur at much lower, more realistic doses.

- The extrapolation from toxic effects in laboratory animals to toxic effects in humans (i.e., responses of animals may be different from responses of humans).

- The conservative estimation of receptor concentrations for constituents of potential concern are above the true average and include maximum values and upper 95 percent confidence limits.

- The pathways selected are the most conservative (i.e., residential).

- Currently there is not a receptor point of contact at either area of concern. At the SGZ mud pits, the potential contamination source is from subsurface soils; and for both the drilling effluent pond and SGZ mud pits area groundwater, there is no domestic well currently present.

- Pathway analyses have been conservative and generally do not include fate and transport considerations (e.g., dispersion, adsorption) in the estimates. 


\section{I.6.0 Groundwater Trigger Levels}

Risk-based trigger levels were developed for the COPCs in groundwater. Trigger levels are suggested concentrations of the COPCs which, if exceeded, would indicate a need to further evaluate site monitoring data. These levels are a risk management tool and do not represent risk levels at which remediation is necessary or at which regulatory levels are exceeded.

\section{I.6.1 Methodology and Equations}

The trigger levels were calculated using modified intake and risk equations to develop the concentration for a given COPC which would be equal to a pre-established risk level. Using the risk equations to target a specific risk level is often referred to as "back-calculating." The Rulison groundwater trigger levels were calculated based on either a incremental lifetime cancer risk of $1 \times 10^{-6}$ or a hazard index of 1.0. The trigger level provided for each COPC is the lower of these two risk levels.

The following are the general equations used to calculate the risk-based trigger levels. All of the input parameters, unless otherwise stated, are the same as those listed in Table 1.3-3.

The carcinogen trigger levels equation is

$$
C_{i}=\frac{A T \times B W \times T R}{E F \times E D \times F \times\left(I R \times S F_{o i}+V F \times I N R \times E T S \times S F_{i i}+S A \times P C_{i} \times E T S \times S F_{o i}\right)}
$$

where

$$
\begin{aligned}
& \mathrm{AT}=\text { Averaging time; period over which exposure is averaged (days) } \\
& \mathrm{BW}=\text { Body weight; the average body weight over the exposure period }(\mathrm{kg}) \\
& \mathrm{C}_{\mathrm{i}} \quad=\text { Constituent-specific trigger level }(\mathrm{mg} / \mathrm{L}) \\
& \mathrm{ED} \quad=\text { Exposure duration (years) } \\
& \mathrm{EF} \quad=\text { Exposure frequency (days/year) } \\
& \mathrm{ETs}=\text { Exposure time showering (hr/day) } \\
& \mathrm{IR} \quad=\text { Ingestion rate (L/day) }
\end{aligned}
$$




$$
\begin{aligned}
& \text { INR = Inhalation rate }\left(\mathrm{m}^{3} / \text { hour }\right) \\
& \mathrm{F} \quad=\text { Fraction of water from site (unitless, 1.0) } \\
& \mathrm{PC}_{\mathrm{i}}=\text { Constituent-specific dermal permeability (EPA, 1992) (see Table I.3-2 for specific } \\
& \mathrm{SA}=\text { Skin surface area }\left(\mathrm{cm}^{2}\right) \\
& \mathrm{Sf}_{\mathrm{oi}}=\text { Oral slope factor }\left((\mathrm{mg} / \mathrm{kg} \text {-day })^{-1}\right) \\
& \mathrm{Sf}_{\mathrm{ii}} \quad=\text { Inhalation slope factor }\left((\mathrm{mg} / \mathrm{kg} \text {-day })^{-1}\right) \\
& \mathrm{TR}=\text { Target risk level (unitless, } 1 \times 10^{-6} \text { ) } \\
& \mathrm{VF}=\text { Volatilization factor (unitless, see Section I.3.2.1.3 for the chemical specific } \\
& \text { calculation process) }
\end{aligned}
$$

The noncarcinogen trigger level equation is

$$
C_{i}=\frac{A T \times B W \times T R}{E F \times E D \times F \times\left(\frac{I R}{R f D_{i}}+\frac{V F \times I N R \times E T s}{R f C_{i}}+\frac{S A \times P C_{i} \times E T s}{R f D_{i}}\right)}
$$

where

$$
\begin{aligned}
& \mathrm{RfD}_{\mathrm{i}}=\text { Reference dose (mg/kg-day) } \\
& \dot{\mathrm{RfC}}_{\mathrm{i}}=\text { Reference concentration (mg/kg-day) } \\
& \mathrm{TR} \quad=\text { Target risk level (unitless, 1.0) }
\end{aligned}
$$$$
\text { AT, BW, } C_{i}, E D, E F, E T s, \mathbb{R}, \mathbb{I N R}, F, P_{i}, S A \text {, and VF are the same as above. }
$$

\subsubsection{Groundwater Trigger Summary}

Table I.6-1 summarizes the risk-based trigger levels for the groundwater COPCs. The detection limits were provided to verify that the established trigger levels are above analytical detection levels. 
Table I.6-1

Summary of Rulison Groundwater Trigger Levels

\begin{tabular}{|c|c|c|}
\hline Chemical & $\begin{array}{l}\text { Risk-Based Trigger Level } \\
(\mathrm{mg} / \mathrm{L})\end{array}$ & $\begin{array}{l}\text { Detection Level } \\
\text { (mg/L) }\end{array}$ \\
\hline Barium & $5.0^{\mathrm{a}}$ & 0.02 \\
\hline Benzene & $0.0052^{b}$ & 0.001 \\
\hline Chromium III & $71^{a}$ & 0.02 \\
\hline Chromium VI & $0.36^{a}$ & 0.02 \\
\hline Ethylbenzene & $5.8^{\mathrm{a}}$ & 0.001 \\
\hline Lead & 1.0 & 0.002 \\
\hline Toluene & $11.5^{\mathrm{a}}$ & .0 .001 \\
\hline TPH as Diesel & $.40 .3^{a}$ & 0.5 \\
\hline Xylenes & $116^{a}$ & 0.001 \\
\hline Radionuclide & $\begin{array}{l}\text { Risk-Based Trigger Level } \\
(\mathrm{pCi} / \mathrm{L})\end{array}$ & $\begin{array}{c}\text { Detection Level } \\
(\mathrm{pCi} / \mathrm{L})\end{array}$ \\
\hline Tritium & $1,300^{c}$ & Varies \\
\hline
\end{tabular}

Based on a combined pathway hazard index of 1.0

Based on a combined pathway incremental lifetime cancer risk of $1 \times 10^{-06}$

Trigger level based on a $10^{-6}$ risk level and not on dose. Established statè and federal regulations may differ significantly. 


\subsubsection{References}

AEC (see U.S. Atomic Energy Commission).

California Department of Toxic Substances Control. 1992. "Draft, Guidance for Site Characterizations and Multimedia Risk Assessment for Hazardous Substances Release Sites," Vol. 7. California Department of Toxic Substances Control. Sacramento, CA.

California Department of Toxic Substances Control. 1993. "Draft, Preliminary Endangerment Assessment Guidance Manual." California Department of Toxic Substances Control, State of California Environmental Protection Agency. Sacramento, CA.

CFR (see Code of Federal Regulations).

Code of Federal Regulations. 1990. Title 40, Part 300, "National Oil and Hazardous Substances Pollution Contingency Plan." U.S. Government Printing Office. Washington, DC.

Doull, J., C.D. Klaassen, and M.O. Amdur. 1980. "Cassaret and Doull's Toxicology." Macmillian Publishing Company. New York, NY.

DTSC (see Cálifornia Department of Toxic Substances Control).

EPA (see U.S. Environmental Protection Agency).

ICRP (see International Commission on Radiological Protection).

International Commission on Radiological Protection. 1975. Report of the Task Group on Reference Man. International Commission on Radiological Protection No. 23.

IT (see IT Corporation).

IT Corporation. 1992. Final Remedial Investigation Report for Group 2 Sites, Mather Air Force Base, California. IT Corporation. Martinez, CA.

Sax, N.I. 1989. "Dangerous Properties of Industrial Materials." 7th ed. New York, NY: Van Nostrand Reinhold Co.

U.S. Atomic Energy Commission. Nevada Operations Office. April 1973. Project Rulison Manager's Report, NVO-71. Las Vegas, NV.

U.S. Environmental Protection Agency. 1985. Rapid Assessment of Exposure to Particulate Emissions from Surface Contamination Sites, EPA/600/8-85/002. U.S. Environmental Protection Agency, Office of Health and Environmental Assessment, Office of Research and Development. Washington, DC. 
U.S. Environmental Protection Agency. 1986. "Superfund Public Health Evaluation Manual," EPA 540/1-86/060. U.S. Environmental Protection Agency, Office of Emergency and Remedial Response, Office of Solid Waste and Emergency Response. Washington, DC.

U.S. Environmental Protection Agency. 1987. "National Primary Drinking Water Regulations Synthetic Organic Chemicals' Monitoring for Unregulated Contaminants," Federal Register, Vol. 52, pp. 25690 - 25734. U.S. Environmental Protection Agency. Washington, DC.

U.S. Environmental Protection Agency. 1989. Risk Assessment Guidance for Superfund (RAGS). Vol. I. "Human Health Evaluation Manual" (Part A), OSWER Directive 9285.7-01A. U.S. Environmental Protection Agency, Office of Emergency and Remedial Response. Washington, DC.

U.S. Environmental Protection Agency. 1991a. Human Health Evaluation Manual, Supplemental Guidance: Standard Default Exposure Factors, Memorandum, OSWER Directive 9285.6-03. U.S. Environmental Protection Agency, Office of Solid Waste and Emergency Response. Washington, DC.

U.S. Environmental Protection Agency. 1991b. Role of the Baseline Risk Assessment in Superfund Remedy Selection Decisions, OSWER Directive 9344.0-30. U.S. Environmental Protection Agency, Office of Solid Waste and Emergency Response. Washington, DC.

U.S. Environmental Protection Agency. 1992. Dermal Exposure Assessment: Principals and Applications, Interim Report, EPA/600/8-91/011B. U.S. Environmental Protection Agency, Exposure Assessment Group, Office of Health and Environmental Assessment. Washington, DC.

U.S. Environmental Protection Agency. 1993. Risk Assessment Review, EPA/600/N-93/014. U.S. Environmental Protection Agency, Region II, Office of Health and Environmental Assessment. New York, NY.

U.S. Environmental Protection Agency. 1995. Health Effects Assessment Summary Tables (HEAST), Annual FY 1993, OERR 9200.6-303 (92-1). U.S. Environmental Protection Agency, Office of Emergency and Remedial Response. Washington, DC.

U.S. Environmental Protection Agency. 1996. Integrated Risk Information System (IRIS). On-line database, maintained by the U.S. Environmental Protection Agency. Washington, DC. 


\section{Distribution List}

Copies

DOE/Nevada Operations Office

Technical Information Resource Center

P.O. Box 98518

Las Vegas, Nevada 89193-8518

U.S. Department of Energy

2 .

Office of Scientific and Technical Information

175 Oak Ridge Turnpike

Post Office Box 62

Oak Ridge, Tennessee 37831

Paul Gretsky

IT Corporation

4330 S. Valley View Blvd., \#114

Las Vegas, NV 89103

Craig Haywàrd

7454 Park Circle

Boulder, CO 80301

Janet Appenzeller-Wing

U.S. Department of Energy

P.O. Box $98518, \mathrm{M} / \mathrm{S} 505$

Las Vegas, NV 89193-8518

Donna Stoner .

Colorado Department of

Public Health and Environment

222 South 6th Street, Room 232

Grand Junction, CO 81501-2768

Carey Weldon

P.O. Box 846

Martin, TN 38237 